UNIVERSIDADE DE SÃO PAULO

INSTITUTO DE GEOCIÊNCIAS

\title{
PETROLOGIA DO BATÓLITO MUNIZ FREIRE, ESTADO DO ESPÍRITO SANTO
}

Igor Eduardo Mascarenhas

Orientador: Prof. Dr. Rômulo Machado

Dissertação apresentada ao Programa de Pós-Graduação em Recursos Minerais e Hidrogeologia para obtenção do título de Mestre em Ciências

SÃO PAULO 


\section{UNIVERSIDADE DE SÃO PAULO INSTITUTO DE GEOCIÊNCIAS}

Petrologia do Batólito Muniz Freire, Estado do Espírito Santo

IGOR EDUARDO MASCARENHAS

Orientador: Prof. Dr. Rômulo Machado

Dissertação de Mestrado

№ 798

COMISSÃO JULGADORA

Dr. Rômulo Machado

Dr. Alexis Rosa Nummer

Dr. Ruy Paulo Philipp

Dr. Daniel Atencio

SÃO PAULO

2018 
Autorizo a reprodução e divulgação total ou parcial deste trabalho, por qualquer meio convencional ou eletrônico, para fins de estudo e pesquisa, desde que citada a fonte.

Serviço de Biblioteca e Documentação do IGc/USP

Ficha catalográfica gerada automaticamente com dados fornecidos pelo(a) autor(a) via programa desenvolvido pela Seção Técnica de Informática do ICMC/USP

Bibliotecários responsáveis pela estrutura de catalogação da publicação: Sonia Regina Yole Guerra - CRB-8/4208 | Anderson de Santana - CRB-8/6658

Mascarenhas, Igor Eduardo

Petrologia do Batólito Muniz Freire, Estado do Espírito Santo / Igor Eduardo Mascarenhas;

orientador Rômulo Machado. -- São Paulo, 2018. $125 \mathrm{p}$

Dissertação (Mestrado - Programa de Pós-Graduação em Recursos Minerais e Hidrogeologia) -- Instituto de Geociências, Universidade de São Paulo, 2018.

1. Granito. 2. Granada. 3. Epídoto Magmático. 4. Petrogênese. 5. Geoquímica. I. Machado, Rômulo, orient. II. Título. 


\section{Agradecimentos}

Muitas das pessoas que eu citarei aqui não atuaram diretamente para que essa dissertação se completasse. Mas o que a maioria das pessoas esquecem é que um trabalho desse tipo, realizado por dois anos, exigindo uma carga emocional gigantesca daquele que o faz, demanda muito mais um "eu estou aqui por você" do que uma ajuda de fato. Além do mais, para grande parte das pessoas que perguntaram sobre o que era meu mestrado, a resposta sempre foi "pedras". Vocês que ouviram isso e mesmo assim se propuseram ajudar: Obrigado.

Quanto aos agradecimentos específicos: Nesses últimos dois anos, tive a oportunidade de dividir a casa com uma pessoa maravilhosa, pessoa essa que eu venho redescobrindo a cada dia, conhecendo melhor e me fascinando mais e mais. Tati, você sempre foi, além de minha irmã, minha companheirona, quem me ensinou grande parte das coisas que eu sei e sempre me oferece um filtro de maturidade que me falta ainda para ver os desafios dos dias de hoje. Quero dizer que você me motiva todos os dias com sua perseverança e determinação e que sem você e todo o apoio que me deu, provavelmente eu não teria terminado esse trabalho. Devo agradecer também aos meus pais que sempre foram não só compreensivos com as minhas decisões, mas também orgulhosos do caminho que estou seguindo e espero, do fundo do meu coração, que eu possa continuar deixando vocês orgulhosos daqui para frente.

O quanto te agradeci pessoalmente ainda não foi suficiente, Bru. Acho que nunca será. Então no caso só espero poder te retornar tudo o que se sacrificou por mim com muito amor, carinho e comida. E como é maravilhoso ter uma namorada geóloga que eu possa realmente parar, explicar o que eu estou tentando dizer, ver sua cara de confusão e repensar o meu trabalho. Obrigado por tornar esses últimos dois anos os mais felizes de minha vida e que continuemos a proporcionar isso um ao outro por muitos outros anos.

Quanto a minha segunda família, os Cenattis, obrigado por todos os dias que vocês me proporcionaram com sua companhia, conversas e risadas regadas a cerveja e comida feita com carinho. Estabilidade emocional passa por ter esses prazeres da vida e sem vocês, provavelmente teria passado por um bocado de tédio fechado no meu quarto.

Quero agradecer especificamente a dois incríveis amigos meus que estão passando por fases similares na vida e entendem a frustração da vida universitária e dos trabalhos acadêmicos. Eugênio e Gabi, valeu por todos os cafés que me tiraram da minha sala, ao mesmo tempo que tiraram a minha cabeça da ciência maluca que eu estava fazendo. Cada frase que conversamos foi um nó desatado no caminho da conclusão do meu trabalho. Vocês ressignificaram os conceitos de ciência e academia para mim, o que me motiva mais ainda a ir até o fim com o meu sonho.

Ao Corcel Negro, que devem ter compreendido porque estou sumido, enfiado na faculdade e com um monte de artigo da cabeça, obrigado. Eu nunca esqueço o quanto é importante ter uma segunda família que a gente pode contar com tudo e todo tipo de apoio quando as coisas derem errado.

Ao VM Geo, valeu por todo o companheirismo e paciência. Eu comecei a fazer o vôlei junto com o mestrado na tentativa de tentar aliar os benefícios físicos e a disciplina para estar bem o suficiente 
para essa fase da vida. Mas no fim me encontrei muitas vezes priorizando o vôlei ao mestrado, de tão feliz que dividir esses momentos com vocês me fez.

E finalmente, agradeço ao Rômulo Machado, meu orientador, uma pessoa incrível, de um coração imenso e uma disponibilidade inabalável. Se um dia eu tiver a oportunidade de orientar alguém, quero fazê-lo como o senhor fez comigo. Ruy Philipp, obrigado por se dispor desde o TF até agora a pacientemente me explicar qualquer coisa que eu tivesse dúvida. $E$ a todos os docentes que atuaram direta e indiretamente, seja respondendo uma dúvida quando parei vocês pelos corredores, ou disponibilizando alguns minutos do seu tempo para me receber em suas salas. 


\section{SUMÁRIO}

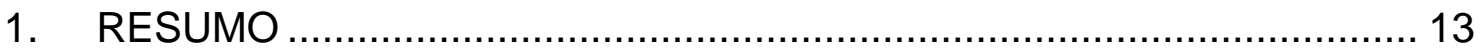

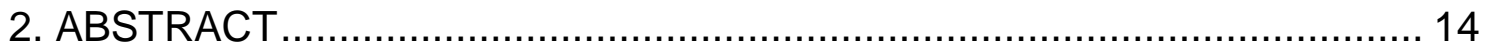

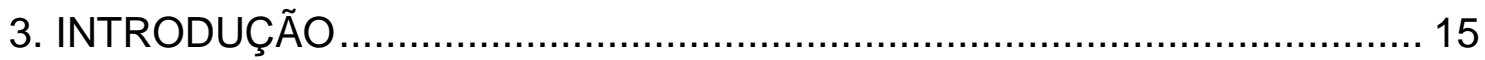

4. OBJETIVOS

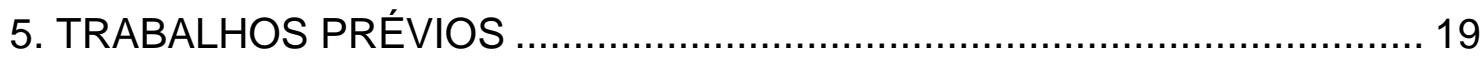

5.1 Geologia e compartimentação tectônica da Faixa Araçuaí...................... 19

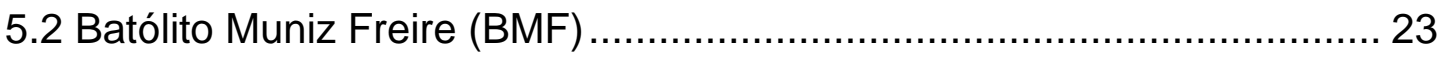

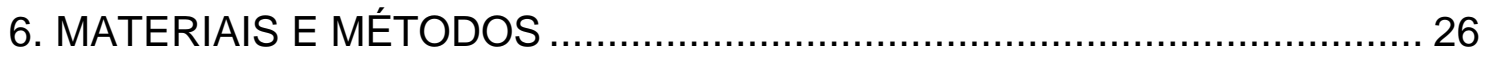

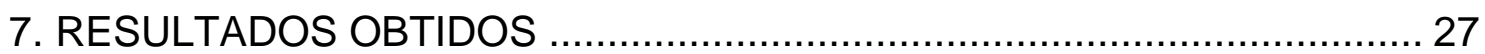

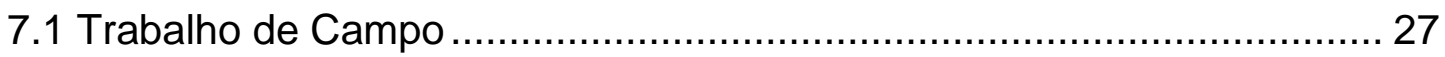

7.1.1 Perfil da porção Sul do batólito....................................................... 28

7.1.2 Perfil da porção central do batólito ................................................ 28

7.1.3 Perfil da porção norte do batólito.................................................... 29

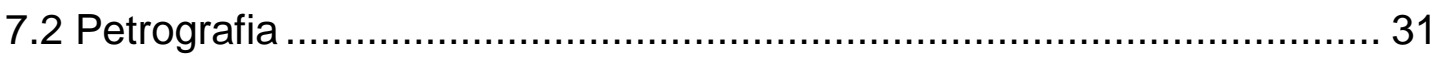

8. INTERPRETAÇÕES E DISCUSSÃO DOS RESULTADOS ………............... 39

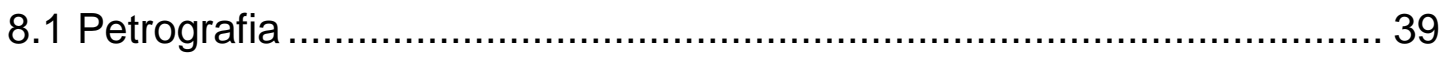

8.2 Observações de Campo …………....................................................... 41

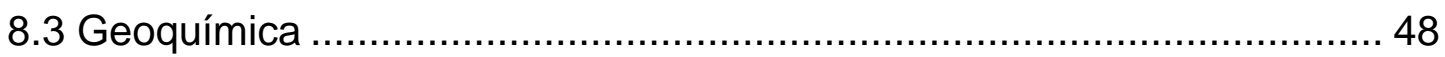

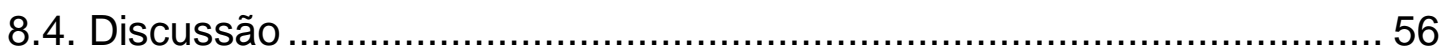

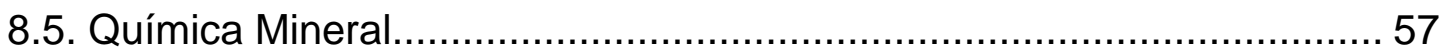

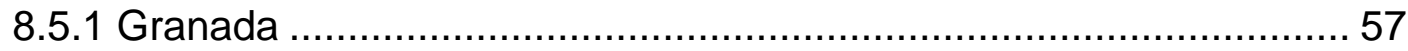

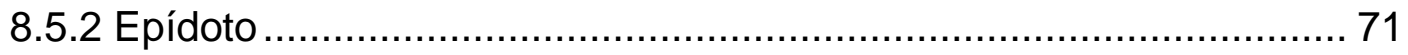

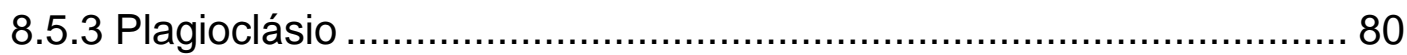

10. DISCUSSÃO DE ORIGEM PARA O BATÓLITO MUNIZ FREIRE .............90

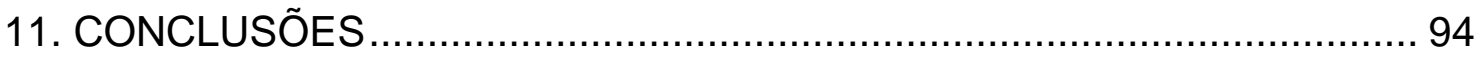

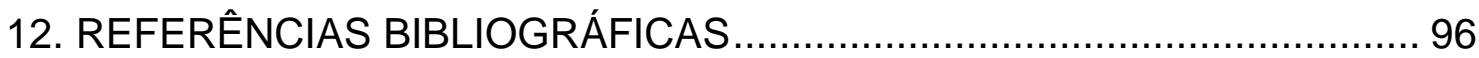




\section{ÍNDICE DE FIGURAS}

Figura 1 - Mapa geológico da região do Batólito Muniz Freire e arredores. 1Grupo Barreiras; 2- Suíte Bela Joana; 3- Suíte Caparaó e charnockitoides; 4Depósitos quaternários; 5- Granitoides Concórdia, São Benedito, Brejatuba, Alfredo Chaves, Alto Viçosinha, Limoeiro e Santa Maria de Baixo; 6- Granitoides Pau-de-Óleo, Colatina, Santa Tereza e São Gabriel da Baunilha; 7- Granitoides tipo I e maciços Afonso Cláudio, Alto Chapéu, Garrafão, Rio Novo do Sul, Santa Angélica, Areçê, Venda Nova e Castelo; 8- Batólito Muniz Freire; 9- Suíte Muniz Freire; 10- Complexo Palmital do Sul; 11- Complexo Paraíba do Sul; 12- Complexo Pocrane; 13- Suíte Muriaé; 14- Suíte Máfica do orógeno Araçuaí; 15- Suíte Natividade. A- Falha inversa ou de empurrão ou ZC transpressional; B- Anticlinal ou antiforme normal; C- Falha ou fratura aproximada; D - ZC transcorrente. Modificado de Silva et al. (2004). 18

Figura 2 - Mapa geológico simplificado da região do Orógeno Araçuaí e sua localização no Gondwana Ocidental. 1. Magmatismo Rio Doce, 2. Plutonismo colisional, 3. Rochas ígneas Tonianas e Criogenianas relacionadas a fases rift, 4. Plutonismo pós-colisional. 5. Formação Ribeirão da Folha e 'lascas ofiolíticas'. 6. Unidades pré-neoproterozoicas, 7. Sucessões metassedimentares e metavulcânicas Neoproterozoicas, 8. Coberturas Cenozoicas, 9. Coberturas do Cráton do São Francisco. Retirado de Tedeschi et al. (2016).

Figura 3 - Mapa da área de estudo com acessos. A área em azul em destaque corresponde ao Batólito Muniz Freire de acordo com Signorelli (1993). Os pontos em vermelho correspondem a afloramentos que foram coletadas amostras para laminação, enquanto os pontos vazios correspondem a afloramentos sem coleta de amostras. Detalhes dos perfis estão expostos na figura 8 para consulta.

Figura 4 - Classificação dos granitos estudados do Batólito Muniz Freire segundo o diagrama QAP de Streckeisen (1967) a partir de análise modal por estimativa visual. Losangos vazios são relativos a diques micrograníticos. 30 amostras. 33

Figura 5 - Fotomicrografias das amostras do Batólito Muniz Freire. A) Amostra PMF-02: Cristais de quartzo estirados e evidenciando extinção em setores do tipo chessboard, com biotita orientada e cristais reliquiares de plagioclásio. B) Amostra PMF-05: Fenocristal de feldspato alcalino com subgrãos nas bordas, inclusão de 
opacos e biotita, mirmequitização e cristal de quartzo estirado com direção concordante à dos cristais de biotita. C) Amostra PMF-05: Fenocristal de feldspato alcalino fraturado e com evidências de recristalização, com fratura preenchida por muscovita. D) Amostra STX-278: Fenocristal de quartzo evidenciando um processo de deformação no grão com formação de extinção em setores do tipo tabuleiro-dexadrez, ou chessboard.

Figura 6 - Fotomicrografias das amostras do Batólito Muniz Freire. A) Amostra PMF-7A: Fenocristais de feldspato alcalino e plagioclásio com mirmequitização no contato entre eles, feldspato alcalino com evidências de recristalização na borda e plagioclásio com sericitização em fratura. B) Amostra PMF-14A: Cristal de epídoto associado a agregado de cristais de biotita e manteando cristal de allanita com geminação simples. C) Amostra PMF-9A: Cristal euhédrico de allanita com evidente zonamento, fraturado e manteado por clinozoisita, associado a cristais de biotita, apatita, titanita. Sem analisador. D) Amostra PMF-24: Feldspato alcalino com subgrãos formados a partir de um único fenocristal que sofreu recristalização. ...... 38

Figura 7 - Fotomicrografias de amostras do Batólito Muniz Freire. A) e B) Amostra STX - 250A. Fenocristais de microclina com fortes evidências de deformação na borda, evidenciando um arranjo granoblástico, onde pequenos cristais de biotita se orientam conforme a deformação. C) e D) feldspato alcalino com borda deformada, formando um arranjo granoblástico semelhante a uma "coroa de grãos". As fotos A) e C) foram obtidas com nicóis paralelos, enquanto em B) e D) foram obtidas com nicóis cruzados.

Figura 8 - Seções realizadas no Batólito Muniz Freire durante trabalho de campo. Os pontos em vermelho correspondem aos locais de coleta das amostras para geoquímica e petrografia, esta última apresentada no anexo I.

Figura 9 - Mapa com a atitude das foliações obtidas no campo e a interpretação do novo limite do Batólito Muniz Freire com base nas informações de campo. A- Falha inversa ou de empurrão ou Zona de Cisalhamento transpressional; B- Anticlinal ou antiforme normal; C- Falha ou fratura aproximada; D - Zona de C transcorrente. EFoliação $S_{n}$ de estiramento e orientação mineral.

Figura 10 - Diagrama de álcalis versus sílica de classificação de rochas plutônicas segundo Middlemost (1994), apresentando amostras dos batólitos Muniz Freire e Galiléia. 
Figura 11 - Diagrama de saturação em alumina segundo. Shand (1949), contendo as amostras dos batólitos Muniz Freire e Galiléia.

Figura 12 - Diagrama $\mathrm{K}_{2} \mathrm{O}$ versus $\mathrm{SiO}_{2}$ proposto por Le Maitre et al. (1989) para classificação das rochas cálcico-alcalinas, incluindo as amostras dos batólitos Muniz Freire e Galiléia.

Figura 13 - Diagramas de variação dos elementos maiores (\%), menores e traços (ppm) versus $\mathrm{SiO}_{2}$ como índice de diferenciação, incluindo as amostras dos batólitos Muniz Freire e Galiléia e suas respectivas fácies micrograníticas.

Figura 14 - Elementos Terras Raras do Batólito Muniz Freire normalizados pelo condrito (Nakamura, 1974). 53

Figura 15 - Diagramas de ambientes tectônicos para as amostras dos batólitos Muniz Freire e Galiléia. A) Diagrama R1 vs R2 (Batchelor e Bowden, 1985). B) Diagrama de Pearce (1996).

Figura 16 - Temperatura de saturação de zircão dos batólitos Muniz Freire e Galiléia pela calibração de Watson e Harrison (1983). $M=\left(\mathrm{Na}+\mathrm{K}+\left(2^{*} \mathrm{Ca}\right)\right) /\left(\mathrm{Al}{ }^{*} \mathrm{Si}\right) .54$

Figura 17 - Histograma com temperaturas de saturação de zircão e apatita dos batólitos Muniz Freire e Galiléia, pela calibração de Watson e Harrison (1983) e Harrison e Watson (1984). 55

Figura 18 - Fotomicrografias e gráficos composicionais de perfis de análise de granada. Os números se referem aos pontos analisados. A) 20 pontos analisados em Gr1. Ao lado, o gráfico referente a essas análises. B) 17 pontos analisados em Gr2. Ao lado, gráfico referente a essas análises.

Figura 19 - Comparação entre granada do Batólito Galiléia (quadrados, estrelas, losangos), experimental (triângulos) e natural (círculos e campos). Os dados experimentais correspondem a granada em equilíbrio com magmas metaluminosos e levemente peraluminosos. O campo pontilhado e os círculos (cheios e vazios) são amostras de granada do Tonalito Bushy Point. A seta aponta para o trend de alta temperatura (HT) para de baixa temperatura (LT). O campo cinza corresponde ao das amostras naturais. Retirado de Narduzzi et al. (2017).

Figura 20 - Perfis e mapas químicos em granada do Batólito Galiléia. A) Granada em biotita-anfibólio-granada-Granitoide. B) Granada em biotita-granada-Granitoide. C) Granada em enclave máfico microgranular. Ao lado das imagens, perfis mostrando 
o padrão de zoneamento de granada utilizando-se dos principais endmembers. Imagem retirada de Narduzzi et al. (2017) Amp = anfibólio; Ep = epídoto; Bt = biotita; Qt = quartzo; PI = plagioclásio; Ttn = Titanita; Ap = apatita.

Figura 21 - Perfis composicionais de granada em metagranitos do Orógeno Dabie-Sul, mostrando o padrão dos principais endmembers e a razão Fe/Mg. Retirado de Xia et al. (2012).

Figura 22 - O caminho P-T-t do crescimento dos cristais de granada dos metagranitos do Orógeno Dabie-Sul durante a subducção. Retirado de Xia et al (2012) 66

Figura 23 - Análises de granada dos bancos de dados GEOROC (Sarbas, 2008) e de Suggate e Hall (2014) separado nos principais endmembers para esse mineral. Os pontos foram separados em cores baseado no grau de diferenciação das rochas, com seus representantes plutônicos e vulcânicos. Pontos em vermelho correspondem a amostras que contém endmembers raros que não foram calculados. Os campos demarcados correspondem à composição de granada dos corpos usados como comparação neste trabalho.

Figura 24 - Gráficos ternários de composição de granada expondo densidade de pontos realizado a partir do gráfico da figura 23. As linhas correspondem às principais tendências de composição de granada para essas rochas.

Figura 25 - Fotomicrografias e gráficos composicionais de perfis de análise de epídoto. Os números se referem aos pontos analisados. Pontos analisados que não correspondem a epídotoss não foram representados no gráfico. Os parâmetros Ps\% e Ca\% foram utilizados por serem as substituições mais importantes.

Figura 26 - Fotomicrografias e gráficos composicionais de perfis de análise de epídoto. Os números se referem aos pontos analisados. Pontos analisados que não correspondem a epídotoss não foram representados no gráfico 72

Figura 27 - Histograma mostrando composições em termos de Ps\% de epídoto magmático de rochas naturais e experimentos. Retirado de Johnston e Wyllie (1988).

Figura 28 - Fotomicrografias de cristais de allanita com borda de epídotoss. Note que para essas amostras, epídotoss apenas manteia allanita quando em contato com biotita. Isso só não é válido para a (a) e (b), onde epídoto se preserva em contato com 
a matriz quartzo feldspática, porém apresenta bordas corroídas. (a), (c) e (e) foram obtidas com nicóis paralelos, enquanto (b), (d) e (f) são, respectivamente, suas contrapartes com nicóis cruzados. (a) e (b) - Amostra STX-278. (c), (d), (e) e (f) Amostra STX-282.

Figura 29 - Fotomicrografias de amostras com epidotoss. (a) e (b) mostram epídoto com núcleo allanítico na amostra STX-278. Epídoto está preservado, com contatos retilíneos, quando em contato com biotita, porém apresenta borda parcialmente corroída quando em contato com plagioclásio e quartzo. É interessante notar nessa amostra a reação (1) da sessão 8.5.3.2 acontecendo na borda do cristal. (c) e (d) mostram cristais de epídoto em contato com biotita e com a matriz quartzo feldspática na amostra STX-279A. Os cristais apresentam pouca ou nenhuma corrosão, por vezes preservando os contatos retilíneos quando em contato com a matriz, o que não ocorre nas outras amostras. As fotos (a) e (c) foram obtidas com nicóis paralelos, enquanto (b) e (d) foram obtidas com nicóis cruzados.

Figura 30 - Solidi (linhas finas) e reações delimitantes dos campos de estabilidade de epídoto magmático (linhas grossas) para diferentes magmas a condições de saturação de $\mathrm{H}_{2} \mathrm{O}$ (exceto para MORB). GRA = Granito, $\mathrm{GD}=$ Granodiorito, $\mathrm{THJ}=$ Throndjemito, $\mathrm{TON}=$ Tonalito, $\mathrm{ANOR}=$ Anortosito, $\mathrm{MORB}=$ Basaltos de dorsal meso-oceânica. Números se referem a An\% normativa (CIPW) de plagioclásio. Área hachurada é referente ao campo de estabilidade de epídoto estimado para rochas do BMF sem limite de pressão, enquanto o campo cinza é para pressões de 8 a 10 Kbar. Modificado de Schmidt e Poli (2004). 78

Figura 31 - Fotomicrografias e gráficos composicionais de perfis de análise de plagioclásio. Os números se referem aos pontos analisados. Cristais que tiveram apenas duas análises não tiveram seus perfis representados. Todas as imagens pertencem à amostra STX-265B 80

Figura 32 - Fotomicrografias e gráficos composicionais de perfis de análise de plagioclásio. Os números se referem aos pontos analisados. Cristais que tiveram apenas duas análises não tiveram seus perfis representados. Todas as imagens pertencem à amostra STX-267. 82

Figura 33 - Fotomicrografias e gráficos composicionais de perfis de análise de plagioclásio. Os números se referem aos pontos analisados. Cristais que tiveram 
apenas duas análises não tiveram seus perfis representados. Todas as imagens pertencem à amostra STX-282. 83

Figura 34 - Fotomicrografia de cristal de plagioclásio com zoneamento inverso. Foi realizado o cálculo da área que corresponde ao núcleo do cristal e à borda do mesmo.

Figura 35 - Modelo de cristalização para o BMF. As fases precoces correspondem aos minerais precoces como biotita e epídoto (titanita, hornblenda, apatita, zircão e allanita não estão representados) e fenocristais dos minerais félsicos. O líquido presente restante após o segundo estágio de cristalização corresponde ao líquido afetado pela dissolução do epídoto. Apesar de não ser possível determinar a proporção líquido rocha quando da dissolução, foi possível determinar a proporção de PI-III vs. PI-total. 89 



\section{RESUMO}

O Batólito Muniz Freire está situado na porção sul do orógeno Araçuaí, na latitude de Vitória e corresponde a um corpo granítico alongado, com área de exposição de aproximadamente $680 \mathrm{~km}^{2}$. A colocação do batólito foi controlada pela Zona de Cisalhamento Guaçuí, que corresponde ao seu contato noroeste. É constituído de monzogranitos a granodioritos com sienogranitos, tonalitos, dioritos e enclaves máficos subordinados. Possui uma foliação no estado sólido heterogênea, sendo marcada pela orientação/estiramento de cristais de biotita e dos minerais félsicos, rotação de feldspatos e bordas com subgrãos. Preserva em zonas de baixa deformação uma foliação definida por porfiroclastos de feldspatos prismáticos e quartzo alongado, além de biotita indeformada. As rochas são de caráter cálcicoalcalina alto-K e marginalmente peraluminosas. Elementos maiores e traços indicam processos de cristalização fracionada, com enriquecimento em ETR leves. As temperaturas de saturação de zircão e apatita são respectivamente $\sim 725^{\circ} \mathrm{C}$ a $\sim 825^{\circ} \mathrm{C}$ e $\sim 875^{\circ} \mathrm{C}$ a $925^{\circ} \mathrm{C}$. A granada tem uma composição não usual para rochas ígneas (rica em grossulária e espessartita), porém semelhante à granada no Batólito Galileia e a outros dois corpos com epídoto magmático e evidências de alta pressão. Epídoto magmático ( $P s=26 \%-30 \%$ ) é fase acessória, estável em tonalitos e metaestável em granodioritos, o que sugere uma pressão mínima de colocação de 8 kbar. Plagioclásio pode ser separado em duas famílias, uma com zoneamento normal e outra com zoneamento inverso, podendo a última ser explicada pela formação de anortita a partir da dissolução de epídoto. A forma alongada do batólito, concordante com a Zona de Cisalhamento Guaçuí associada à presença de uma foliação magmática que transiciona nas bordas para uma foliação milonítica, sugere que a colocação do magmatismo foi contemporânea à atividade principal da referida estrutura. Deformação, composição e dados isotópicos indicam compatibilidade com rochas sincolisionais. 


\section{ABSTRACT}

The Muniz Freire Batholith is located on the southern part of the Araçuaí orogen, on Vitória's latitude and correspond to an elongated granitic body with an exposition area of around $680 \mathrm{~km}^{2}$. Its intrusion was controlled by the Guaçuí Shear Zone, which corresponds to its northwest boundary. The batholith is constituted by monzogranites to granodiorites with subordinate occurrence of sienogranites, tonalites, diorites and mafic enclaves. It presents a solid-state deformation that is pervasive through the body, highlighted by the alignment/stretching of the biotite and felsic minerals. In low deformational zones, however, presents an orientation featured by igneous relics with little to no deformation, strained quartz crystals and undeformed biotite. The chemical affinity of these rocks is high-K calc-alkaline, with peraluminous affinity and strong evidences of differentiation processes, light REE enrichment. Zircon and apatite saturation temperatures are, respectively, $\sim 725^{\circ} \mathrm{C}$ to $\sim 825^{\circ} \mathrm{C}$ and $\sim 875^{\circ} \mathrm{C}$ to $925^{\circ} \mathrm{C}$. Garnet presents an unusual composition for igneous rocks (high grossular and spessartine), although similar to Galiléia Batholith garnet and to garnet of other two bodies with magmatic epidote and high pressure evidences. Magmatic epidote (Ps = $26 \%-30 \%$ ) is an accessory mineral, stable in tonalites, metastable in granodiorites, suggesting a minimum emplacement pressure of $8 \mathrm{kbar}$. Plagioclase can be split into two families: one with normal zoning and other with reverse zoning, which might be explained by anortite introduction in the system by epidote dissolution. The elongated shape of the batholith, consistent with the Guaçuí Shear Zone, associated with the presence of a magmatic foliation that gerated on his border portions of mylonitic rocks suggests that the evolution of this magmatism is contemporaneous to the orogenic metamorphism of high temperature that affected the region. Deformation, composition and isotopic data show compatibility with sincollisional rocks. 


\section{INTRODUÇÃO}

O Batólito Muniz Freire (BMF) está localizado no estado do Espírito Santo, batizado com o nome do município localizado em sua região sul. Abrange uma área de cerca de $680 \mathrm{~km}^{2}$, balizado a oeste pela zona de cisalhamento Guaçuí e intrusivo com rochas indiscriminadas do Complexo Paraíba do Sul (Figura 1). Está inserido na extremidade sul da Faixa Araçuaí, próximo ao limite com a Faixa Ribeira (sensu Pedrosa-Soares e Noce, 1998) e tem sido considerado por alguns autores como representante do magmatismo pré- a sincolisional (Figueiredo e Campos Neto, 1991, 1993) e mesmo pós-colisional (Figueiredo e Campos Neto, 1991) ou simplesmente pré-colisional (Pedrosa-Soares et al., 2001).

Apesar de trabalhos anteriores já terem definido um cinturão orogênico na região do Rio de Janeiro, denominado Cinturão Paraíba (Ebert, 1968), a definição da Faixa Araçuaí por Almeida (1977) como uma faixa de dobramentos brasilianos adjacentes às bordas sul e sudeste do Cráton São Francisco é a mais aceita. Sua área de abrangência foi estendida até o litoral Atlântico e o seu limite meridional considerado até o paralelo $21^{\circ} \mathrm{S}$, sendo a referida faixa (sensu Almeida, 1977) englobada posteriormente no Orógeno Araçuaí-Congo Ocidental (Pedrosa-Soares e Noce, 1998, Pedrosa-Soares e Wiedemann-Leonardos, 2000; Pedrosa Soares et al., 2001) e na 'Microplaca Serra do Mar' com o desenvolvimento de um arco magmático (590 a 570 Ma) e relacionado à "Orogenia Rio Doce" (Figueiredo e Campos Neto, 1993; CamposNeto e Figueiredo, 1995).

A Faixa Araçuaí (FA) é considerada por muitos autores como a contraparte brasileira do cinturão Congo Ocidental na África, separados pela abertura do oceano Atlântico, levando-se em conta a existência de uma ponte cratônica que o Cráton São Francisco faz com Cráton do Congo na latitude do Gabão e Bahia (Almeida, 1967). A evolução tectônica dessa faixa tem sido intensamente debatida, com autores classificando-a como um orógeno intraplaca (Trompette, 1994) ou como um orógeno confinado (Pedrosa-Soares et al., 2001). Atualmente, considera-se que esse segmento orogênico possui todos os componentes de um orógeno de colisão, como bacia precursora, representada pelo Grupo Macaúbas; magmatismo da fase rift, representado pelos diques máficos da Suíte Pedro Lessa, granitos anorogênicos da Suíte Salto da Divisa e xistos verdes basálticos (Membro Rio Preto) da Formação Chapada Acauã (Pedrosa-Soares et al., 2007); arco magmático continental, representado pelo Batólito tonalítico da Suíte Galiléia (Nalini, 1997; Pedrosa-Soares 
et al., 1999); ofiolitos, representado por fatias de rochas ultramáficas da Formação Riberão da Folha (Pedrosa-Soares et al., 1992) e granitoides peraluminosos (tipo-S) sin a tardi-colisionais (Pedrosa-Soares e Wiedemann-Leonardos, 2000).

O magmatismo granítico neoproterozoico da FA foi dividido por Pedrosa Soares et al. (1999) em cinco suítes (G1 a G5), designadas, da mais antiga para a mais nova, de: G1- suíte sintectônica, constituindo o núcleo anatético do orógeno, com batólitos ortognássicos do tipo-l; G2- suíte sintectônica, cálcico-alcalina, com granitoides tipo-S; G3- suíte tardi-tectônica, com granitos peraluminosos tipo-S; G4suíte tardi- a pós-tectônica, cálcico-alcalina alto-K, com granitos tipo-I, incluindo os maciços com associação charnockítica (Aimorés, Padre do Paraíso, dentre outros); G5- suíte pós-tectônica, com predomínio de granitos peraluminosos, tipo-S, em maciços zonados, contendo biotita-granitos no centro e granitos com duas micas ou muscovita-granada granitos nas bordas. Posteriormente, Pedrosa Soares e Wiedemann-Leonardos (2000) consideraram a suíte G2 (agora denominada G1) como sendo mais antiga do que a suíte G1 (agora denominada G2), caracterizandoa como pré-colisional (entre 625 e $595 \mathrm{Ma}$ ) e esta como sincolisional (entre 595 e 575 Ma). Novos limites de idade para as suítes foram definidos por Pedrosa-Soares et al. (2011), sendo eles: G1 (630-585 Ma), G2 (585-560 Ma), G3 (545-525 Ma), G4 e G5 (530-480 Ma). Nos trabalhos mais recentes de Pedrosa-Soares e colaboradores, o BMF é descrito como um representante inequívoco do magmatismo G1, junto de outros granitoides como a Suíte Galiléia e Batólito São Vitor (Pedrosa-Soares et al. 2001, 2007, 2011).

O batólito alvo deste estudo é descrito com uma rocha foliada nas mais variadas direções, sendo por vezes chamado de gnaisse granitoide (Signorelli, 1993). Apresenta texturas milonítica e cataclástica próximas às bordas da Zona de Cisalhamento Guaçuí. Sua composição é predominantemente granítica, com variações para granodiorítica a tonalítica, onde apresentam cor cinzenta.

Söllner et al. (1987) obtiveram inicialmente uma idade U-Pb em zircão de $580+20$ e -6 Ma para o BMF, a partir da datação de três zircões euhedrais. Mais recentemente, Pedrosa-Soares et al. (2011) determinaram uma idade de $588 \pm 4 \mathrm{Ma}$, pelo método U-Pb em zircão por LA-ICP-MS, com base na datação de 25 cristais de zircão. Estas idades pertenceriam às supersuítes G1 ou G2 (Pedrosa-Soares et al., 2011), considerando a margem de erro. 
Este trabalho apresenta uma revisão das pesquisas anteriores sobre o Orógeno Araçuaí, incluindo as características petrográficas, geoquímicas, geocronológicas, isotópicas e tectônicas da granitogênese do referido orógeno, particularmente a considerada na literatura como pré-colisional, Suíte G1 de Pedrosa-Soares e colaboradores. São aqui apresentados e discutidos dados de campo, petrográficos, geoquímicos e de químíca mineral (epídoto, granada, plagioclásio) do Batólito Muniz Freire, incluindo também os dados geocronológicos $\mathrm{U}-\mathrm{Pb}$ em zircão e isotópicos ( $\mathrm{Sr}$, $\mathrm{Nd)}$ disponíveis na literatura para o referido batólito. Os resultados obtidos são discutidos visando elucidar a origem do batólito e compará-los com o dos granitos da Suíte $\mathrm{G} 1$, considerando um modelo tectônico que não envolve subducção de uma litosfera oceânica para geração da referida suíte granítica, o qual contempla a fusão crustal de uma crosta de rochas ortognáissicas e metassedimentares do Complexo Paraíba do Sul, com idade dominantemente Riaciana.

\section{OBJETIVOS}

Este trabalho tem como objetivo geral contribuir para a caracterização da petrogênese do BMF, no Estado do Espírito Santo, bem como discutir a origem do magmatismo do batólito no âmbito do magmatismo pré-colisional (Suíte G1) do Orógeno Araçuaí, segundo modelo tectônico proposto por Pedrosa-Soares e colaboradores.

Como objetivos específicos, são aqui definidos: 1) composição mineralógica, petrográfica e geoquímica das rochas do batólito, 2) principais estruturas e texturas presentes nas suas diferentes faciologias; 3 ) processos de cristalização magmática e as características do magmatismo a partir da interpretação dos diagramas de caracterização geoquímica e discriminação de séries magmáticas; 4) classificação tectônica do batólito em relação ao magmatismo ao Orógeno Araçuaí; 5) determinação das condições geotermobarométricas do batólito com base nos estudos petrográficos e de química mineral do epídoto e granada. 


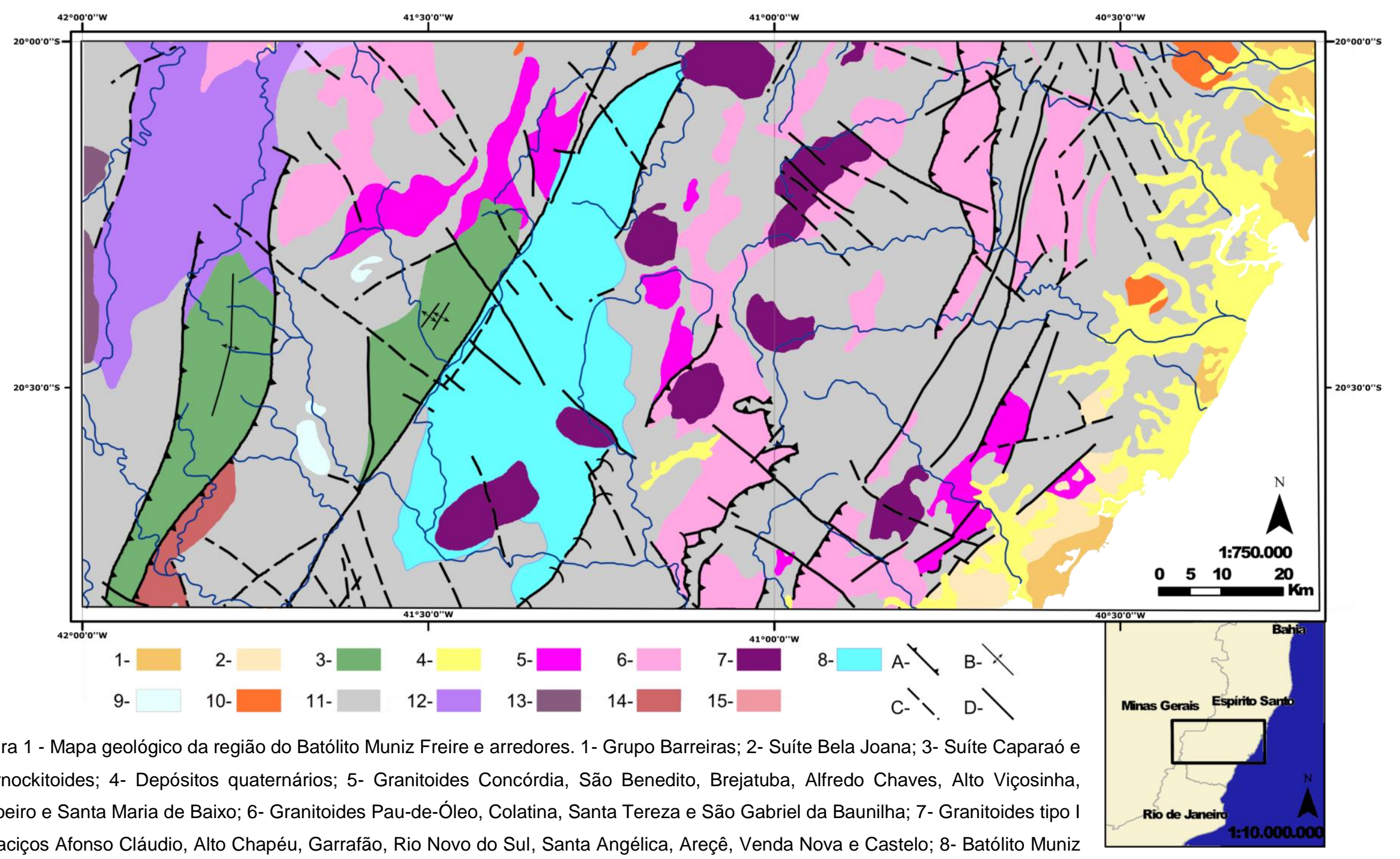

Freire; 9- Suíte Muniz Freire; 10- Complexo Palmital do Sul; 11- Complexo Paraíba do Sul; 12- Complexo Pocrane; 13- Suíte Muriaé; 14- Suíte Máfica do orógeno Araçuaí; 15- Suíte Natividade. A- Falha inversa ou de empurrão ou ZC transpressional; B- Anticlinal ou antiforme normal; C- Falha ou fratura aproximada; D - ZC transcorrente. Modificado de Silva et al. (2004) 


\section{TRABALHOS PRÉVIOS}

\subsection{Geologia e compartimentação tectônica da Faixa Araçuaí}

A Faixa Araçuaí ocupa uma posição tectônica peculiar, confinada em uma reentrância cratônica definida pelos crátons do São Francisco e do Congo, sendo as faixas Araçuaí e Oeste Congo contrapartes de um mesmo orógeno, separadas pela abertura do Oceano Atlântico. Neste contexto, o Araçuaí-Oeste Congo seria a fração norte de um grande orógeno gerado no Ciclo Orogênico Brasiliano-Pan Africano e que resultou na formação das faixas de dobramento Ribeira, Dom Feliciano, Kaoko, Damara, Gariep e a própria faixa Araçuaí-Oeste Congo (Pedrosa Soares e Wiedemann-Leonardos, 2000).

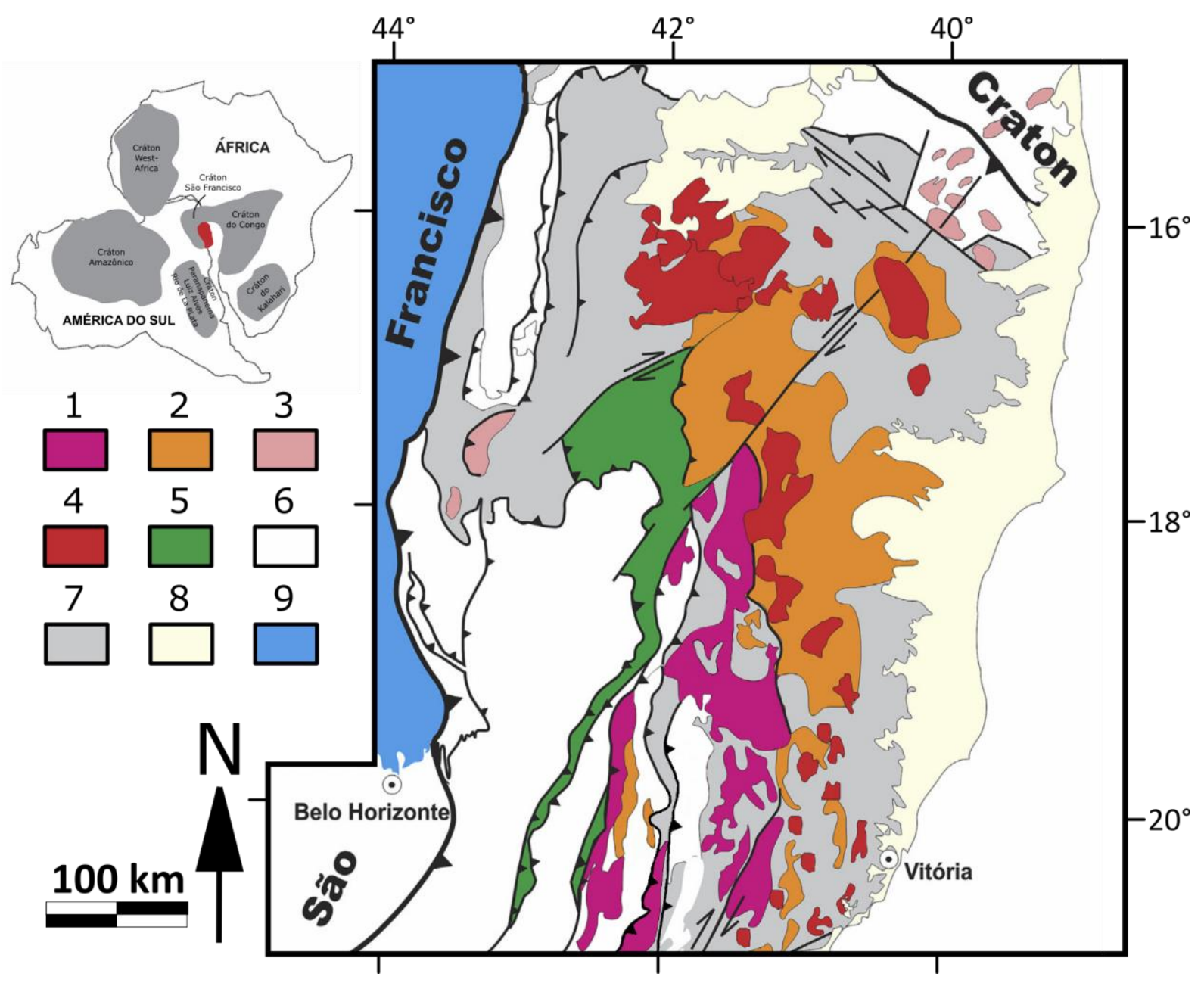

Figura 2 - Mapa geológico simplificado da região do Orógeno Araçuaí e sua localização no Gondwana Ocidental. 1. Magmatismo Rio Doce, 2. Plutonismo colisional, 3. Rochas ígneas Tonianas e Criogenianas relacionadas a fases rift, 4. Plutonismo pós-colisional. 5. Formação Ribeirão da Folha e 'lascas ofiolíticas'. 6. Unidades préneoproterozoicas, 7. Sucessões metassedimentares e metavulcânicas Neoproterozoicas, 8. Coberturas Cenozoicas, 9. Coberturas do Cráton do São Francisco. Retirado de Tedeschi et al. (2016). 
Siga Jr. (1986) propôs a divisão da Faixa Araçuaí, com base em dados geocronológicos, em dois domínios tectônicos: um domínio externo (ou Ocidental) e um domínio interno (ou Centro-Oriental). O Domínio Externo é composto por metassedimentos de baixo grau metamórfico, representado pelas rochas dos grupos Macaúbas e Espinhaço, além de rochas gnáissico-migmatíticas do Complexo Itacambira-Barrocão com idades arqueanas a paleoproterozoicas. O Domínio Interno contém rochas do período de acreção crustal da faixa, ocorrido durante o ciclo Brasiliano, com a Formação Salinas sendo evidência deste processo, bem como a extensa granitogênese gerada nesse período, e que foi dividida em três episódios: (1) sin- a tardi-tectônico (650-550 Ma), (2) tardi- a pós-tectônico (550-500 Ma), e (3) póstectônico a anorogênico (500-450 Ma).

O Projeto de Levantamento Geológico Básico - PLGB - realizado pela CPRM na região do Vale do Rio Doce, em escala 1: 100.000 (Folhas Afonso Cláudio, Domingos Martins e Cachoeiro do Itapemirim), dividiu os maciços graníticos em três grupos tectônicos principais: (1) pré- a sintectônico às fases de metamorfismo regional; (2) sin-transcorrentes e, (3) pós-transcorrentes (Féboli, 1993; Silva, 1993).

Pedrosa Soares e Wiedemann-Leonardos (2000) descrevem também dois domínios distintos, um externo e outro interno, os quais são muito semelhantes aos domínios descritos por Siga Jr. (1986). De acordo com estes autores, o domínio externo é caracterizado por uma estrutura em arco simétrico e conecta dois aulacógenos chamados Paramirim, no Brasil, e Sangha, na África. Os lados opostos do domínio externo apresentam vergência tectônica centrífuga, exibindo estruturas de baixo a moderado ângulo, como foliação dúctil regional, cavalgamentos e superfícies axiais de dobras assimétricas, com sentidos opostos: uma com a vergência das estruturas em direção ao Cráton do São Francisco (para Oeste) e outra com a vergência em direção ao Cráton do Congo (para Leste). As sequências neoproterozoicas mostram, junto às bordas cratônicas, metamorfismo de fácies xistoverde inferior a anfibolito inferior. O domínio interno, limitado à Faixa Araçuaí, tem orientação geral NNE a N-S e é interrompido pela estruturação arqueada que define o setor norte da referida faixa. O extenso plutonismo Neoproterozoico/Cambriano é caraterístico deste domínio. Dois subdomínios distintos são ainda reconhecidos: um a norte da latitude $19^{\circ} S$, com vergência marcante para SW, que se caracteriza por empurrões oblíquos de mergulhos baixos a moderados com uma componente de movimento destral, correspondendo à zona anatética do metamorfismo regional e da 
granitogênese e situado na região onde a faixa está melhor exposta; outro a sul da latitude 19S até $21^{\circ}$ S, caracterizado por zonas de cisalhamento de alto ângulo de mergulho, com cinemática destral, o qual expõe um nível crustal mais profundo com rochas de alto grau, incluindo as de fácies granulito e os complexos intrusivos com associação charnockítica, zonados, com núcleos de composição máfica/intermediária e evidências de mistura de magmas (mixing and mingling), a exemplo dos complexos Aimorés, Várzea Alegre, Pedra Preta, etc. (Wiedemann et al., 1987, De Campos et al., 2004; Wiedemann, 1993; Mello et al., 2011).

Campos-Neto e Figueiredo (1995) dividiram a faixa Araçuaí em diversos terrenos, sendo eles: (1) Microplaca Serra do Mar, (2) Cinturão Juiz de Fora, (3) as sequências de rift mesoproterozoicas e (4) Microplaca Guanhães. A Microplaca Serra do Mar corresponde a um extenso cinturão linear que se estende pela costa brasileira, e que registra um arco magmático resultante da convergência de placas. Esse arco corresponde à orogenia Rio Doce, composta dominantemente de migmatitos e granitoides. É constituída por três terrenos (segmentos) metamórficos de alto grau distintos: (i) supracrustral, (ii) gnáissico-migmatítico e (iii) granito-migmatíticogranulito. O cinturão Juiz de Fora é constituído pelos terrenos infracrustais Juiz de Fora e Mantiqueira e supracrustal do Paraíba do Sul. Os dois primeiros são caracterizados por gnaisses cinzentos e granulitos e o último por migmatitos com relíquias de sedimentos plataformais. As sequências de rift mesoproterozoicas são formadas pelos grupos Espinhaço e São João Del Rey. A Microplaca Guanhães inclui rochas metamórficas de alto grau e apresenta registro de vulcanismo riodacítico do Mesoproterozoico.

Costa et al. (1995) propõem uma subdivisão muito semelhante à de CamposNeto e Figueiredo (1995), argumentando uma colagem de terrenos de origens distintas para a formação do cinturão Araçuaí, o qual, apesar da localização da área de estudo estar de acordo com definições anteriores deste cinturão, se optou pela definição de Campos-Neto e Figueiredo (1990) que denominavam a região como uma extensão do Cinturão Ribeira. Costa et al. (1995) argumentam a existência de três terrenos: (1) Microplaca Manhuaçu, domínio metassedimentar onde ocorreu grande parte do plutonismo sinorogênico; (2) domínio de arco de ilha e metassedimentos de margem passiva ou bacia de retroarco; (3) Prisma Acrescionário correspondente as rochas do Complexo Mantiqueira. A construção do orógeno viria da aglutinação e 
edificação desses domínios a partir de uma subducção para leste ou duas subducções seguidas uma da outra, a primeira para oeste e a segunda para leste.

Söllner et al. (2000) fazem uma compilação das idades disponíveis na região sul do Cinturão Araçuaí e delimitam alguns eventos importantes que ocorreram na área de estudo, a saber:

(1) Zircão herdados em paragnaisses metamorfizados no Brasiliano: 2981 Ma e $2845 \mathrm{Ma}$ (U-Pb em zircão);

(2) Zircão herdados em rochas ígneas e metamórficas brasilianas: $2169 \pm 3 \mathrm{Ma}$, $2185 \pm 8 \mathrm{Ma}$ e $2055 \mathrm{Ma}$ (U-Pb em zircão)

(3) Primeiro evento metamórfico e anatexia: $605 \pm 3$ Ma e $590 \pm 3 \mathrm{Ma}$ (U-Pb em zircão);

(4) Magmatismo sin-orogênico: $580 \pm 13 \mathrm{Ma}$ (U-Pb em zircão - Idade do BMF), $527 \pm 3 \mathrm{Ma}$ e $535 \pm 3 \mathrm{Ma}$ (U-Pb em monazita);

(5) Pico do metamorfismo: $571 \pm 3 \mathrm{Ma}$ (U-Pb em zircão);

(6) Evento termal regional: $519 \pm 13 \mathrm{Ma}$ (U-Pb em zircão), $503 \pm 8 \mathrm{Ma}$ e $521 \pm 9$ $\mathrm{Ma}$ (U-Pb em titanita)

(7) Granitogênese pós-orogênica: $480 \pm 4 \mathrm{Ma}, 495 \pm 5 \mathrm{Ma}$ e $513 \pm 8 \mathrm{Ma}$ (U-Pb em zircão)

(8) Evento de resfriamento regional com retenção de isótopos em biotita: $458 \pm$ $13 \mathrm{Ma}$ (K-Ar em biotita) e $471 \pm 10 \mathrm{Ma}$ (Rb-Sr em biotita).

Gradim et al. (2014) fazem uma importante análise sobre a bacia de retro-arco relacionada com o Arco Magmático Rio Doce. A partir de estudos de proveniência, concluem que paragnaisses aluminosos do Complexo Nova Venécia têm três fontes de sedimentos mais importantes: (1) o Arco Magmático Rio Doce; (2) o Arco Magmático Rio Negro, localizado no Cinturão Ribeira e, (3) o embasamento Paleoproterozóico. As rochas do Complexo Nova Venécia, por consequência de uma complexa mistura de fontes de calor (ascensão da astenosfera, espessamento crustal, cavalgamento do arco magmático por sobre o retro-arco), sofreram fusão parcial de suas rochas, gerando a granitogênese G2, representada principalmente pelo Batólito Carlos Chagas, em um processo acompanhado pela deformação e metamorfismo regional do estágio colisional. 
Tedeschi et al. (2016) revisaram o entendimento do Arco Magmático Rio Doce ressaltando a sua importância na definição do arco magmático gerado pela subducção de litosfera oceânica, retomando assim o nome introduzido por Figueiredo e Campos-Neto (1993). De acordo com estes autores, o Arco Magmático Rio Doce estende-se por $550 \mathrm{~km}$, desde o setor norte do Orógeno Araçuaí até o Cinturão Ribeira. Devido ao grau de exumação do referido arco magmático, as rochas vulcânicas foram erodidas e por este motivo são menos comuns do que os granitos da Supersuíte G1. Sustentado pelos dados isotópicos e geoquímicos das rochas da referida supersuíte, sugere-se que o Arco Magmático Rio Doce é um arco magmático pré-colisional, que foi desenvolvido em uma margem continental ativa, apresentando, porém, uma contribuição crustal mais expressiva do que o esperado para esse tipo de orógeno, como indicam os dados isotópicos apresentados pelos citados autores. Essas evidências são atribuídas a configuração tectônica singular onde evoluiu o Orógeno Araçuaí, a de um ambiente de confinamento entre dois crátons, configurando um orógeno confinado (sensu Pedrosa-Soares et al., 2001) (Figura 2).

Karniol e Machado (2010) estudaram a cinemática do Orógeno Araçuaí em sua porção-Sul, considerando como base as suas feições estruturais e um fluxo tectônico para SSW. Eixos de dobras e lineações apresentam certo paralelismo, sugerindo que estas estruturas se formaram provavelmente durante um único evento transpressional que afetou o orógeno. A coexistência de rochas com feições assimétricas (como milonitos e gnaisses milonitizados) e rochas com menor grau de deformação pode ser atribuída a partição da deformação em diferentes escalas, situação essa comum em orógenos desenvolvidos em regime transpressivo.

\subsection{Batólito Muniz Freire (BMF)}

A área de ocorrência do BMF caracteriza-se por uma topografia com relevo alçado, com morros isolados, sendo comuns feições do tipo "Pão de Açúcar", incluindo vales encaixados e relevo serrano com feições abauladas. O solo, de cor castanho-amarronzado a amarelada, apresenta composição areno-argilosa.

O batólito se localiza aproximadamente na latitude de Vitória, a cerca de $110 \mathrm{~km}$ a oeste da capital, próximo ao limite do estado do Espírito Santo com Minas Gerais. Seu limite sudeste está localizado a $32 \mathrm{~km}$ a noroeste de Cachoeiro do Itapemirim. $O$ BMF possui área de exposição de aproximadamente $680 \mathrm{~km}^{2}$ e aflora em uma faixa contínua de direção NE-SW com extensão de 90 km e largura média de cerca de 12 
$\mathrm{km}$. Devido às suas dimensões relativamente grandes, os limites do BMF passam por oito municípios: Alegre, Jerônimo Monteiro, Cachoeiro do Itapemirim, Muniz Freire, Castelo, Conceição do Castelo, Brejetuba e Afonso Cláudio (Figura 3).

O contato oeste do batólito é marcado pela Zona de Cisalhamento de Guaçuí, descrita como uma estrutura de alto ângulo com movimento destral e inverso (empurrão) com a capa (hanging wall), localizada a leste da mencionada estrutura, com evidências de transporte tectônico de sudeste para noroeste (Signorelli, 1993; Silva, 1993). Esta estrutura separa o batólito dos paragnaisses de alto grau do Complexo Paraíba do Sul e rochas charnokitoides da Suíte Caparaó (Silva et al. 2004). O limite leste é definido pela Zona de Cisalhamento de Piracema, marcando o contato com o Batólito Estrela e com uma sequência de paragnaisses do Complexo Paraíba do Sul (Signorelli, 1993; Silva, 1993; Silva et al. 2004).

Signorelli (1993) descreve as rochas do batólito como gnaisses granitoides, de composição dominantemente granítica, com variações para granodiorítica e tonalítica. Apresenta cor cinza a cinza clara, textura milonítica do tipo flaser, granulação média a grossa, localmente porfiroblástico, sendo constituído essencialmente de feldspato alcalino (microclínio), plagioclásio (anortita $=15-20 \%$ ), quartzo e biotita e, como acessórios, inclui apatita, zircão, allanita, titanita, hornblenda e granada. O corpo possui estrutura foliada, a qual varia em direção e em mergulho. São comuns alterações metamórficas relacionadas a atuação de fluidos tardios como sericitização nos feldspatos, epídotização e cloritização na biotita e hornblenda, bem como albititização e epídotização nas bordas de cristais de plagioclásio.

Figueiredo e Campos Neto (1991) descrevem as rochas do batólito como biotita granitos leuco- a hololeucocráticos, incluindo um corpo gabroico de extensão decamétrica e finos diques disruptos de monzogabro e quartzo-monzonito subordinados, incluindo ainda hornblenda-biotita granitoides com magnetita, titanita, zircão e apatita como minerais acessórios e enclaves microgranulares (gabro-dioritotonalito-granodiorito). O magmatismo é caracterizado como cálcio-alcalino e de composição expandida. Suas características geoquímicas são consideradas típicas de granitoides pré-colisionais, relacionados à subducção de uma crosta oceânica. Descrevem, também, biotita granitos com granada, muscovita, magnetita, zircão, apatita e titanita como acessórios, cuja composição é semelhante ao de granitoides tardi-orogênicos, enquanto os diagramas multi-elementares sugerem semelhança com os de granitos pós-colisionais. 
A composição química das rochas básicas do batólito é relacionada com os basaltos do Chile central e interpretada como derivada de uma área-fonte mantélica enriquecida com componentes de zona de subducção, a qual englobaria tanto um enriquecimento intraplaca quanto ao de um manto empobrecido (Figueiredo e Campos Neto, 1991). Os gabros da sequência cálcio-alcalina são considerados mais primitivos do que os termos básicos e talvez eles possam representar produtos com graus mais elevados de fusão parcial da mesma área-fonte mantélica enriquecida e heterogênea. Segundos estes autores, os magmas básicos poderiam ter gerado, por diferenciação, a sequência cálcio-alcalina.

Karniol e Machado (2010), em uma seção estrutural entre Marechal Floriano e Itatiba, sintetizam as principais feições estruturais do BMF e o descrevem como com "estrutura que varia de maciça a orientada, com foliação magmática incipiente em zonas de baixa deformação até gnáissica nas zonas de máxima deformação, particularmente nas bordas". Sua textura é principalmente equigranular hipidiomórfica média nas porções mais homogêneas e equigranular fina nas bordas do batólito. $O$ comportamento da foliação no batólito é bastante heterogêneo, por vezes com orientação concordante com a foliação metamórfica, por vezes discordante, particularmente com mergulhos mais suaves, formando uma geometria das foliações em leque, sugerindo a presença de estruturas em flor. Predominam, no geral, estruturas de direção NNE com mergulhos altos, que variam de WSW para ESE.

Figueiredo e Campos Neto (1991) mencionam uma idade de 600-580 Ma, obtida por Söllner et al. (1987) e atribuem como sendo a idade das rochas da sequência cálcio-alcalina, apesar do zircão ter sido "coletado um pouco ao sul da área em estudo". Os autores também mencionam idades de 520-490 Ma para os granitoides isótropos intrusivos no BMF. Além disso, concluem que a idade dos biotita-granitos deve situar-se entre 580 e $520 \mathrm{Ma}$, e que estas rochas foram originadas pela fusão de crosta inferior (ortognáissica ou granulítica) espessada pelo evento colisional.

Dados isotópicos de razões ${ }^{87} \mathrm{Sr} /{ }^{86} \mathrm{Sr},{ }^{147} \mathrm{Sm} /{ }^{144} \mathrm{Nd}$ e ${ }^{144} \mathrm{Nd} /{ }^{143} \mathrm{Nd}$ para rochas do BMF foram obtidos por De Campos et al. (2004) e estão expostos na tabela 1.

\begin{tabular}{|l|l|l|l|l|l|l|l|l|}
\hline${ }^{147} \mathrm{Sm} /{ }^{144} \mathrm{Nd}$ & ${ }^{143} \mathrm{Nd} /{ }^{144} \mathrm{Nd} 0$ & ${ }^{143} \mathrm{Nd} /{ }^{144} \mathrm{Nd} d_{i}$ & $\varepsilon_{\mathrm{Nd}(0)}$ & $\varepsilon_{\mathrm{Nd}(\mathrm{i})}$ & $\mathrm{T}_{\mathrm{DM}}(\mathrm{Ga})$ & $\mathrm{U} / \mathrm{Pb}$ & ${ }^{87} \mathrm{Sr} /{ }^{86} \mathrm{Sr}_{0}$ & ${ }^{87} \mathrm{Sr} /{ }^{86} \mathrm{Sr}_{\mathrm{i}}$ \\
\hline 0,0919 & $0,511733 \pm 14$ & 0,511426 & $-17,65$ & $-10,84$ & 1,628 & $\begin{array}{l}580 \pm \\
6\end{array}$ & 0,716357 & 0,71163 \\
\hline
\end{tabular}

Tabela 1. Dados isotópicos retirados de De Campos et al. (2004). ${ }^{143} \mathrm{Nd} /{ }^{144} \mathrm{Nd} 0$ e ${ }^{87} \mathrm{Sr} /{ }^{86} \mathrm{Sr}$ referem-se a valores medidos. ${ }^{143} \mathrm{Nd} /{ }^{144} \mathrm{Nd}$ e e ${ }^{87} \mathrm{Sr} / 86 \mathrm{Sr}_{i}$ referem-se a valores iniciais para $510 \mathrm{Ma}$. Idade U/Pb retirada de Söllner et al. (1987). 


\section{MATERIAIS E MÉTODOS}

Foi realizada uma atividade em campo que consistiu de uma viagem de três dias na área de estudo, onde foram feitos três perfis cortando o batólito: o primeiro na parte sul do mesmo, o segundo na parte central, e o terceiro na parte norte do batólito (figura 3 e 8). Nessa atividade de campo, foram coletadas novas amostras em pontos ainda não visitados anteriormente no batólito pelo orientador do trabalho. Com isso, além do autor ter tido a possibilidade de se familiarizar com a área de estudo, teve-se como resultado dessa etapa de campo uma amostragem mais representativa do corpo.

As 34 amostras coletadas em campo foram preparadas para estudos petrográficos, geoquímicos e de química mineral.

Para o estudo das lâminas delgadas foi empregado o microscópio petrográfico Olympus BX40, disponível no Laboratório de Microscopia Ótica do Instituto de Geociências da USP. Foi feita a descrição textural, mineralógica e modal (por estimativa visual) de lâminas delgadas, confeccionadas a partir das amostras coletadas no campo. As descrições petrográficas das referidas lâminas encontram-se sumarizadas no Anexo I e as interpretações encontram-se no item 8.1 da presente dissertação.

As amostras coletadas em campo, após uma seleção prévia e uma análise petrográfica, foram encaminhadas para análises geoquímicas de elementos maiores, menores, traços e terras raras. Os resultados das análises encontram-se na tabela 1 e o seu tratamento, interpretação e discussão são apresentados no item 6.3. As determinações geoquímicas (elementos maiores, menores, traços e terras raras) foram realizadas no Acme Labs - ACME Analítica Laboratórios Ltda., localizado em Vespasiano, MG, utilizando-se para determinação dos elementos de um espectrômetro ICP-OES (emissão óptica com plasma induzido acoplado), modelo 3410 da ARL pelo método LF200. As amostras encaminhadas para análises geoquímicas foram preparadas da seguinte maneira:

- Lavagem - esta etapa foi realizada para remover qualquer resíduo de solo e de matéria orgânica presente nas amostras;

-Redução granulométrica - utilizou-se uma marreta para redução das amostras até a fração de aproximadamente $5,0 \mathrm{~cm}^{3}$; 
-Quarteamento - foi utilizado para a redução de volume das amostras e para que se mantivesse uma porção representativa da amostra original;

- Britagem - as amostras foram moídas em moinho de bolas até obter-se a sua pulverização na fração pó;

- Peneiramento- foram separadas as frações de 100 meshes para as análises geoquímicas e para a separação de grãos de zircão que serão usados eventualmente para datação geocronológica pelo método U-Pb.

Os mapas apresentados neste trabalho foram confeccionados no software ArcGis da empresa ESRI (Environmental Systems Research Institute) com a ferramenta ArcMap (10.2.2) e posteriormente foram retocados para melhor apresentação nos editores de imagens de código aberto Inkscape e GIMP 2.

Os processos de determinação de química mineral foram realizados na Microssonda Eletrônica JEOL JXA-8530F Field Emission Electron Probe Microanalizer do Instituto de Geociências da Universidade de São Paulo. Foram realizadas análises quantitativas WDS em cristais de epídoto (para determinação de endmembers e zoneamento), granada (determinação de endmembers e geotermobarometria), plagioclásio (para determinação do teor de anortita e estudo do zoneamento) e biotita (determinação de endmembers). As configurações utilizadas para o feixe de elétrons foram de $15 \mathrm{kV}, 20 \mathrm{nA}$ e diâmetro de $5 \mu \mathrm{m}$ para epídoto e granada e de $10 \mu \mathrm{m}$ para plagioclásio.

A preparação de tabelas e organização dos dados obtidos em microssonda eletrônica foram realizados utilizando-se de ferramentas do Pacote Microsoft Office Professional Plus 2013 (Excel, Word) e o software de edição de texto Sublime Text 3. Os gráficos de classificação geoquímica e discriminação tectônica foram confeccionados com a utilização do software GCDKit 3.0 (GeoChemical Data toolkit - Janousek et al. 2006) e retocados utilizando-se do Inkscape mencionado acima.

\section{RESULTADOS OBTIDOS}

\subsection{Trabalho de Campo}

O trabalho de campo consistiu em três perfis que cortam transversalmente o BMF. Os perfis demonstram no geral uma homogeneidade textural e composicional, com pequenas variações entre as áreas estudadas. 


\subsubsection{Perfil da porção Sul do batólito}

O Perfil da parte Sul do batólito foi realizado partindo-se do centro urbano de Guaçuí em direção ao município de Alegre. Como o início da amostragem encontravase muito próximo da zona de cisalhamento (ZC) de Guaçuí, as primeiras amostras estavam fortemente alteradas e com foliação subvertical paralela à direção da ZC. Nesta região, são comuns veios quartzosos e quartzo feldspáticos cortando as rochas miloníticas associadas à ZC. $\mathrm{O}$ bandamento destas rochas é centrimétrico a decimétrico, com a estrutura variando com relação à sua continuidade, ocorrendo por vezes bandas melanocráticas e leucocráticas bem definidas, com feições sigmoidais frequentes, podendo conter anfibólio ou biotita como máfico principal (ponto 7). 0 batólito é estruturalmente homogêneo, foliado, com estruturas sempre simétricas em relação à foliação e sem bandamento evidente na escala de afloramento, mesmo junto às bordas do corpo, sendo composto sistematicamente de quartzo, feldspato (plagioclásio e feldspato alcalino) e biotita como máfico principal. Esta rocha possui cor cinza a cinza clara, com fenocristais de feldspatos pouco estirados e quartzo formando ribbons. Nesta seção pode-se observar um afloramento de paragnaisse de origem metapelítica com biotita, silimanita, granada, muscovita, feldspato e quartzo, pertencente ao Complexo Paraíba do Sul, indicando proximidades do contato sul com o BMF.

\subsubsection{Perfil da porção central do batólito}

O Perfil Central foi realizado na estrada partindo do município de Muniz Freire em sentido ao município de Castelo. A maioria das amostras foram coletadas neste devido ao baixo grau de alteração intempérica dos afloramentos, provavelmente relacionado com a maior distância da ZC Guaçuí. Ao longo do perfil é possível observar as feições geomorfológicas típicas do batólito, como morros isolados e em forma de 'pão-de-açúcar'. Nos paredões desses morros é possível ver, à distância, diques decimétricos, em geral de cor clara, cortando de forma discordante a foliação das rochas do batólito em diversas direções. Alguns desses diques, observados e amostrados em afloramentos, são de sienogranitos (PMF-11B, PMF-14B, PMF-14C). Possuem cor cinza clara e apresentam estrutura foliada a levemente foliada, sendo definida pelo alinhamento de cristais de biotita, quartzo e feldspato. A textura é granoblástica, de granulação média a grossa, composta por quartzo, plagioclásio, feldspato alcalino, pequenas quantidades de biotita e, ocasionalmente, granada. Esta foliação mostra mergulho em geral para sul-sudoeste, orientação que não é 
compatível com a direção da ZC Guaçuí. A composição varia de sienogranítica (diques) a granodioritica. Observam-se enclaves granodioríticos com bandamento magmático interno e maior conteúdo de minerais máficos do que a rocha circundante. No geral, os diferentes afloramentos visitados mostram uma grande homogeneidade estrutural, textural e mineralógica.

\subsubsection{Perfil da porção norte do batólito}

Este perfil estende-se desde uma bifurcação próxima ao acesso da estrada para Brejetuba até o centro urbano de Afonso Cláudio. Nesta região, observa-se um muscovita-biotita-quartzo xisto com alteração de cor marrom e apresentando duas direções de foliação muito fortes, indicando tratar-se de um domínio fora do BMF, porém nas vizinhanças da ZC Guaçuí, provavelmente de paragnaisses pertencentes ao Complexo Paraíba do Sul ou de alguma unidade não cartografada e que foram envolvidos pela deformação relacionada à atividade desta estrutura. Os granitos do BMF neste perfil são semelhantes aos encontrados no Perfil Central, situado mais no centro do batólito, porém, observa-se aqui uma granulação relativamente mais grossa e um aumento no conteúdo de fenocristais de feldspato alcalino. Em afloramento distante da ZC Guaçuí, está presente uma foliação muito forte e subvertical. Esta rocha apresenta alguma alteração devido a sua estrutura, sendo um indício de que há ramificações da ZC Guaçuí não mapeadas que cortariam porções mais internas da extremidade norte do BMF. 


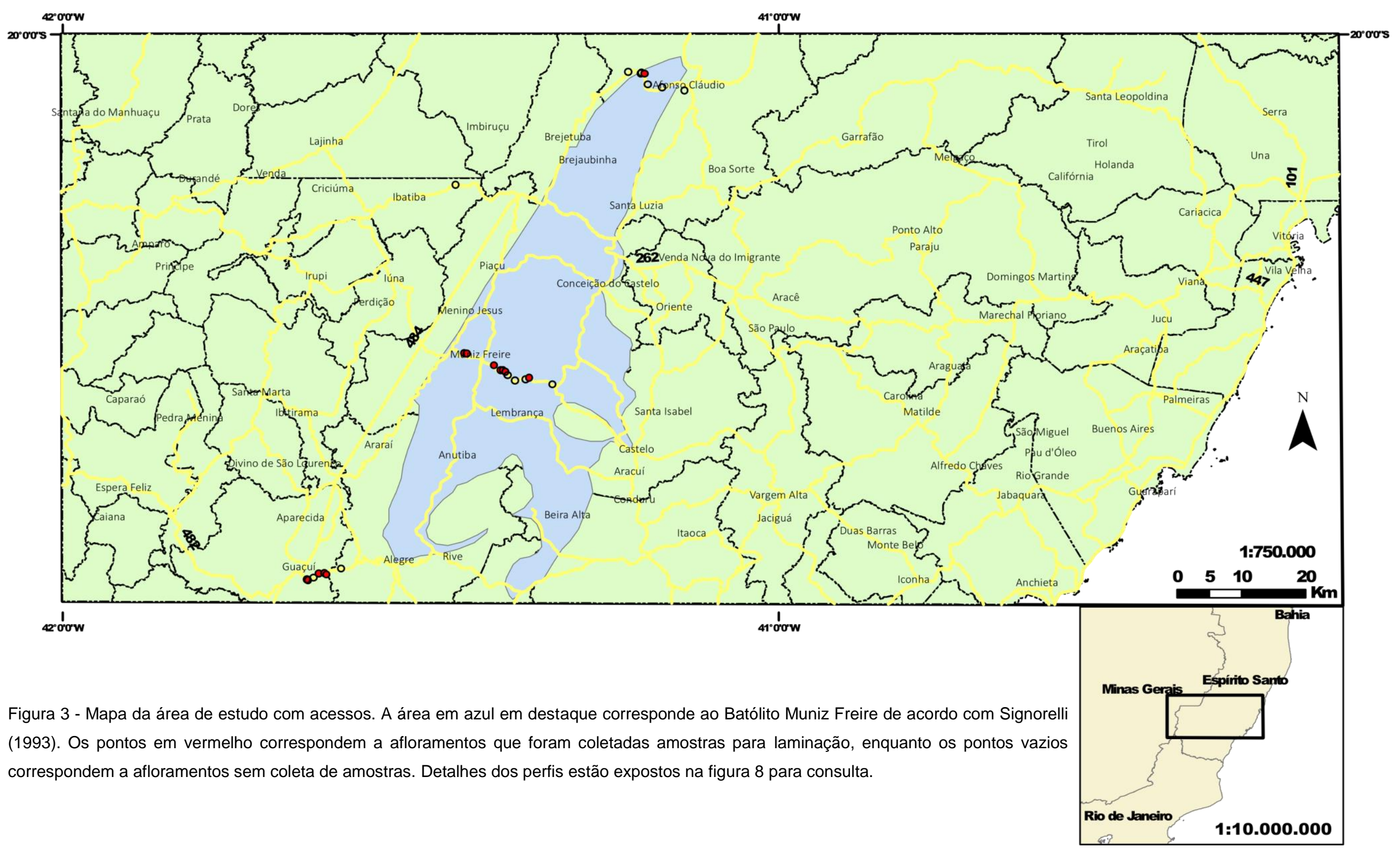




\subsection{Petrografia}

Nas lâminas analisadas, alguns minerais puderam ser identificados a partir de suas propriedades óticas. Contudo, não foi possível separar a espécie especifica do subgrupo/grupo que pertence outros minerais. Logo, no texto que segue, serão utilizados nomes genéricos para se referir a estes

Anfibólio verde - hornblenda

Mica escura - biotita

Mica clara - muscovita

Mineral do subgrupo allanita - allanita

Mineral do subgrupo plagioclásio - plagioclásio

Mineral do subgrupo feldspato alcalino - feldspato alcalino

Mineral do subgrupo clorita - clorita

Mineral do grupo apatita - apatita

Com base nas descrições de lâminas delgadas (apresentadas no anexo I para referência) das amostras coletadas no Batólito Muniz Freire, segue abaixo uma síntese da petrografia das mesmas.

A análise petrográfica das amostras do BMF evidenciou certa uniformidade mineralógica e textural das rochas do batólito, apresentando, uma variação composicional de sienogranito a granodiorito e, subordinadamente, tonalito (Figura 4). Essas rochas apresentam uma estrutura em geral foliada marcada pelo alinhamento de minerais prismáticos e placoides, que pode evoluir para um bandamento discreto a pobremente definido, caracterizado por finas bandas de biotita e acessórios intercalados com finas bandas ricas em minerais félsicos. As amostras estudadas apresentam-se deformadas e as texturas porfiríticas a inequigranulares primárias foram modificadas e recristalizadas por ação de um evento de deformação dúctil, que promoveu a superposição de uma textura com arranjo granoblástico, em geral inequigranular, com limites de grãos interlobados a poligonizados, definido pelo arranjo de agregados de feldspatos e quartzo. Feições reliquiares são comuns em zonas de mais baixa taxa de deformação, onde ocorrem porfiroclastos de feldspatos com formas prismáticas subédricas. Observa-se 
também quartzo alongado sem feições internas evidentes de deformação ou, mais comumente, apresentando extinção ondulada do tipo chessboard (figuras 5A e 5D). Os porfiroclastos de feldspatos (Figuras 5B e 7) estão circundados por uma matriz mais fina, definida por agregados de feldspatos e quartzo com textura granoblástica poligonal a interlobada média.

A foliação é a feição estrutural mais marcante na maioria das amostras, sendo definida pela orientação de forma de minerais prismáticos como os feldspatos e hornblenda, quando presente, pelo alinhamento de cristais de mica escura e também por cristais de quartzo alongados. Os agregados de mica escura formam schlieren descontínuos a relativamente contínuos, marcados por finos níveis de espessura milimétrica. Esses agregados variam em continuidade e regularidade, transicionando para um bandamento discreto ou mais raramente para um bandamento mais acentuado, a exemplo da amostra PMF-7B. Esse bandamento é no geral caracterizado por um aspecto irregular, pouco contínuo, com as bandas escuras, formadas por biotita e acessórios, não ultrapassando alguns milímetros. No caso da referida amostra, o bandamento é mais proeminente e tem dimensões centrimétricas, além de ser menos irregular e contínuo. Este último está localizado na borda sul do batólito, porém não se repete nos pontos próximos ou em qualquer outra amostra coletada no mesmo.

A ausência de feições deformacionais assimétricas nas amostras pouco deformadas, tais como caudas de deformação em porfiroclastos de feldspatos estirados, estruturas do tipo $\delta$ e pares $S-C$ de foliações, sugere que a deformação predominante foi relacionada a um regime de cisalhamento puro. Porém em amostras mais deformadas, há intensa recristalização na borda de fenocristais de feldspato alcalino e plagioclásio, com um arranjo granoblástico muito fino, sugerindo que localmente houve uma componente de cisalhamento simples para essa deformação.

A textura dominante das amostras analisadas com maior deformação é a granoblástica poligonizada a interlobada, de granulação média, caracterizada por agregados recristalizados contendo feldspato alcalino, plagioclásio e quartzo. Contudo, para amostras com deformação incipiente, domina a textura milonítica. Os porfiroclastos de quartzo apresentam forma alongada segundo à foliação desenvolvida pela deformação no estado sólido (Fig 5A) ou por cristalização durante fluxo magmático. Estes cristais ocorrem associados com agregados de pequenos 
cristais poligonizados ou não de feldspato alcalino e plagioclásio. Em zonas de baixa deformação, ocorrem cristais de feldspato alcalino e plagioclásio de tamanhos entre $1 \mathrm{~mm}$ e $4 \mathrm{~mm}$, com formas prismáticas pouco alongadas e subédricas. Nas zonas de maior deformação, podem apresentar extinção ondulante. Nestes casos, os porfiroclastos encontram-se circundados por uma matriz constituída por cristais menores de feldspatos e quartzo, dispostos em um arranjo granoblástico (Figuras 5B e 5C), sugerindo que houve recristalização no estado sólido durante o processo de metamorfismo e deformação que afetou as texturas magmáticas.

O alinhamento dos cristais de biotita evidencia uma textura lepidoblástica média e marca de forma clara a foliação da rocha. Porém, biotita não apresenta deformação evidente para a grande maioria das amostras.

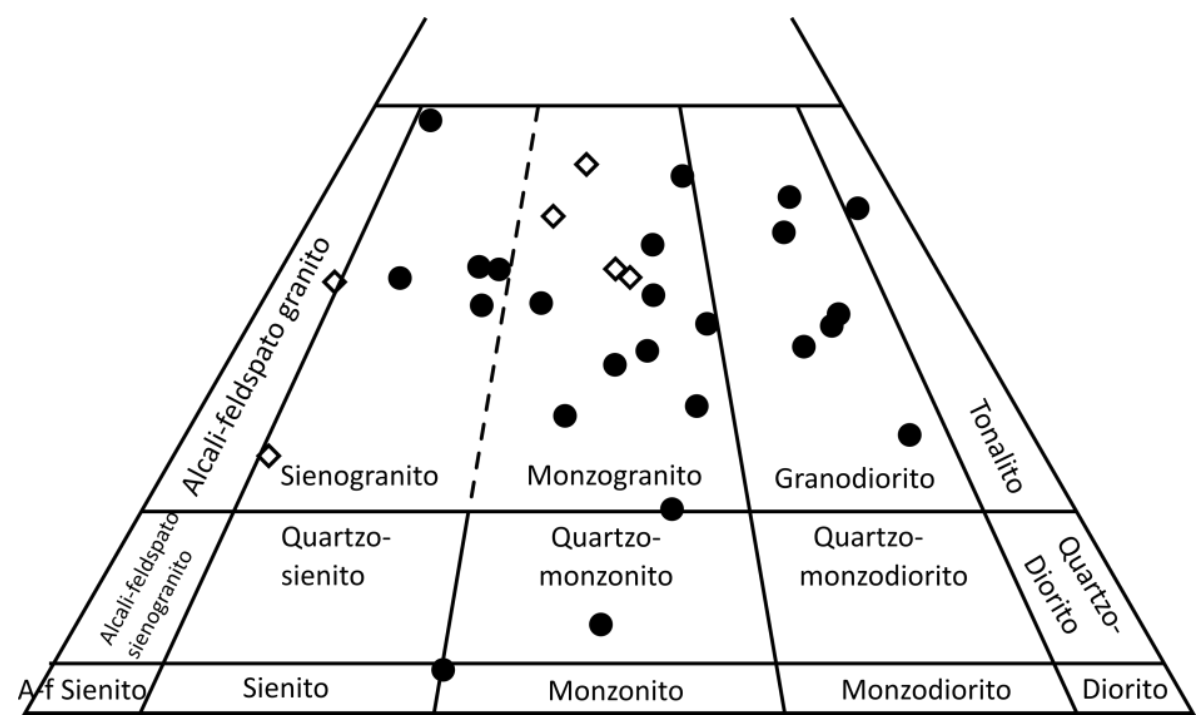

Figura 4 - Classificação dos granitos estudados do Batólito Muniz Freire segundo o diagrama QAP de Streckeisen (1967) a partir de análise modal por estimativa visual. Losangos vazios são relativos a diques micrograníticos. 30 amostras. 

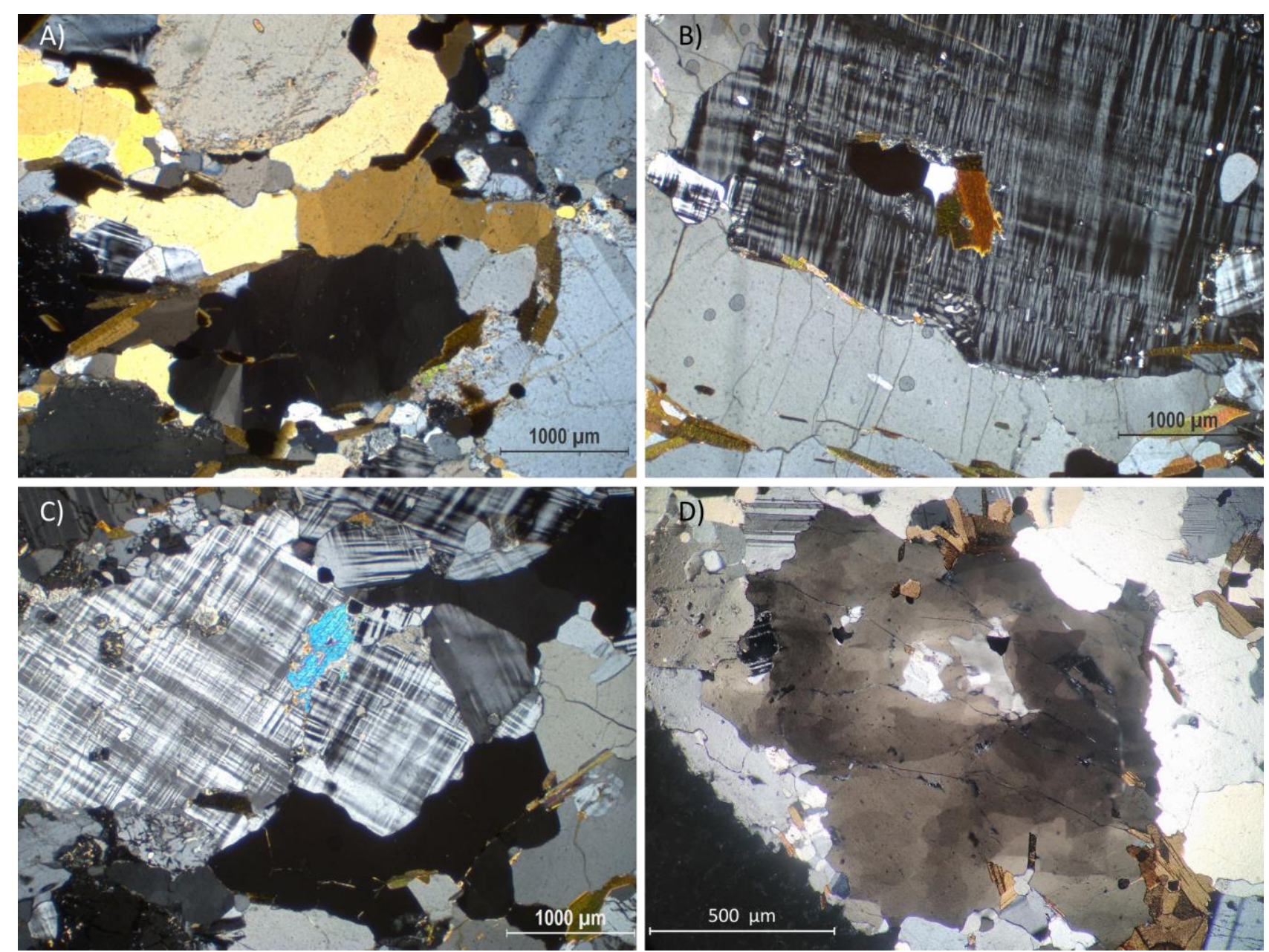

Figura 5 - Fotomicrografias das amostras do Batólito Muniz Freire. A) Amostra PMF-02: Cristais de quartzo estirados e evidenciando extinção em setores do tipo chessboard, com biotita orientada e cristais reliquiares de plagioclásio. B) Amostra PMF-05: Fenocristal de feldspato alcalino com subgrãos nas bordas, inclusão de opacos e biotita, mirmequitização e cristal de quartzo estirado com direção concordante à dos cristais de biotita. C) Amostra PMF-05: Fenocristal de feldspato alcalino fraturado e com evidências de recristalização, com fratura preenchida por muscovita. D) Amostra STX-278: Fenocristal de quartzo evidenciando um processo de deformação no grão com formação de extinção em setores do tipo tabuleiro-de-xadrez, ou chessboard. 
O quartzo ocorre comumente na matriz na forma de pequenos cristais em arranjo granoblástico poligonal ou com contatos interlobados, com evidências de deformação no estado sólido e com estruturas que indicam recristalização por migração de limites de grãos. Alguns subgrãos apresentam extinção ondulante e maclas de deformação. Esses cristais apresentam tamanhos entre 0,1 a $0,6 \mathrm{~mm}$. Os porfiroclastos mostram tamanho médio entre 2 e $5 \mathrm{~mm}$, podendo chegar até $7 \mathrm{~mm}$. Mostram-se geralmente alongados na direção da foliação e exibem, com frequência, extinção ondulante por setores (tipo chessboard) (Figura 5D). Outra forma de ocorrência está associada a formação de mirmequitas quando feldspato alcalino está em contato com Plagioclásio (Figura 6A). Neste caso, os cristais são vermiformes e apresentam tamanhos inferiores a $0,2 \mathrm{~mm}$.

O feldspato alcalino ocorre comumente recristalizado formando agregados de cristais com formas poligonais, substituindo os subgrãos de um porfiroclasto maior (Figura 6D). Na matriz, apresentam tamanhos entre 0,2 e 0,5 mm e estão associados com cristais de quartzo e plagioclásio. Os porfiroclastos reliquiares apresentam tamanho entre 2 e $3 \mathrm{~mm}$, podendo chegar até $5 \mathrm{~mm}$. Neste caso apresentam contatos irregulares, porém com forma prismática equidimensional a pouco alongada, sugerindo domínios que escaparam de uma possível deformação. Estes cristais, no entanto, podem apresentar fraturas preenchidas por muscovita tardia (Figura $5 \mathrm{C}$ ). Em algumas amostras mais deformadas, cristais maiores podem vir a preservar internamente suas feições originais, porém suas bordas podem estar completamente deformadas, apresentando uma coroa de subgrãos gerados por recristalização, possivelmente devido a rotação desses cristais maiores (Figura 5B e 7).

O plagioclásio ocorre, na maioria das amostras estudadas, em duas gerações distintas. Uma delas se expressa como cristais poligonizados ou com limites irregulares, sem geminação evidente e zoneamento inverso quando observado com clareza. Essa geração tem como característica cristais menores (no geral $<0,5 \mathrm{~mm}$ ). A outra geração é composta por porfiroclastos com forma prismática, pouco alongados, subédricos, com tamanho médio entre 1 a $2 \mathrm{~mm}$ e máximo de $4 \mathrm{~mm}$, e com zoneamento normal, definido por núcleos mais cálcicos. A geminação, quando presente, é principalmente segundo a Lei da Albita ou em conjunto, segundo a Lei de Carlsbad. Os cristais menores mostram tamanhos entre 0,1 e 0,6 mm, seguindo a tendência de tamanho dos cristais da matriz granoblástica. A saussuritização varia de moderada a incipiente, ocorrendo geralmente substituição parcial por 


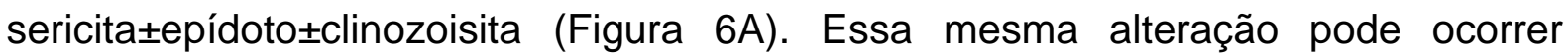
também nos cristais reliquiares. Os contatos são irregulares e, por vezes, preservam sua forma original (subédrica) com hábito tabular bastante evidente. O ângulo máximo de extinção dos cristais de plagioclásio é próximo de $10^{\circ}-15^{\circ}$, sugerindo um baixo teor de anortita e uma composição entre oligoclásio e albita. Como o feldspato alcalino, pode ocorrer com coroas de subgrãos gerados por recristalização dinâmica.

A biotita ocorre como cristais prismáticos e subidiomórficos, com pleocroísmo variando de cor castanha escura a castanha clara. Os cristais estão orientados e marcam a foliação principal. Ocorrem, em geral, como agregados constituindo bandas descontínuas com espessura média entre 1 a $2 \mathrm{~mm}$. Associam-se minerais acessórios, como hornblenda, titanita, allanita e epídoto (Figura 6B e 6C). Pode ocorrer também inclusa em cristais de quartzo, plagioclásio e, mais raramente, no feldspato alcalino. Por vezes, os cristais ocorrem substituídos por muscovita ou clorita, porém essas feições são relativamente incomuns.

A allanita é o mineral acessório mais comum das amostras estudadas e aparece como cristais zonados, idiomórficos, com tamanho entre 1 a $3 \mathrm{~mm}$, podendo exibir geminação simples (Figura 6B e 6C). Apresenta-se comumente envolta por manto total ou parcial de epídoto. Ocorre associada com biotita e os cristais são orientados segundo à foliação da rocha.

A titanita ocorre como pequenos cristais xenomórficos a subidiomórficos, ou em agregados, podendo atingir até $0,8 \mathrm{~mm}$, associados comumente com a biotita (Figura $6 C)$.

A apatita é mais rara e ocorre como diminutos cristais $(\sim 0,1 \mathrm{~mm})$ com tendência circular. Associa-se com a biotita e ocorre também na matriz granoblástica sem evidência aparente de deformação (Figura 6C).

O zircão aparece como cristais subidiomórficos a idiomórficos, com tamanho relativamente grande, entre 0,2 a $0,4 \mathrm{~mm}$, podendo ocorrer incluso em cristais reliquiares de plagioclásio e em cristais deformados de quartzo ou mesmo entre eles.

A clorita está intimamente associada com a biotita e muscovita, ocorrendo como cristais dispostos ao longo das bordas ou de seus planos de clivagens. Apresenta forma xenomórfica a subidiomórfica, birrefringência baixa e com pleocroísmo em tons de verde escuro a verde claro. 
O epídoto (sensu strictu) apresenta forma equidimensinonal, xenomórfico a idiomórfico, geralmente nas bordas de allanita e, salvo exceções, bordejado por biotita (Figura 6B). Seus contatos apresentam feições de reabsorção, como corroídos, quando ocorrem junto da matriz quartzo-feldspática, mais comumente com plagioclásio. Quando em contato com biotita, seus contatos tendem a ser retilíneos.

A clinozoisita ocorre como cristais equidimensionais e subidiomórficos, podendo ser produto de alteração (saussuritização) do plagioclásio, mas ocorre também manteando allanita (Figura 6C).

A muscovita aparece de várias formas distintas: como cristais xenomórficos preenchendo fraturas de cristais reliquiares de feldspato alcalino ou plagioclásio, como massas criptocristalinas da alteração pervasiva do plagioclásio, como sericita associada ao epídoto e/ou a clinozoisita ou ainda como cristais subidiomórficos formados possivelmente a partir de alteração da biotita.

Os minerais opacos são raros e apresentam-se em geral bem formados com seções quadráticas a retangulares. Ocorrem como cristais isolados, de tamanhos entre 0,5 e 2,0 mm, ou ainda como agregados (até $4 \mathrm{~mm}$ ) preenchendo fraturas.

A granada aparece em poucas amostras, sendo que uma delas representa um dique leucogranítico (amostra PMF-11B) onde apresenta forma subidiomórfica e tamanhos entre 0,5 e 0,8 mm. Na amostra PMF-09B, os cristais de granada apresentam bordas irregulares e inclusões de plagioclásio e quartzo.

A hornblenda ocorre nas amostras menos diferenciadas e está sempre associada com a biotita. Ocorre como cristais subidiomórficos, de tamanhos entre 1,0 e 1,5 mm, com pleocroísmo variando de verde-oliva a verde-amarelada. 


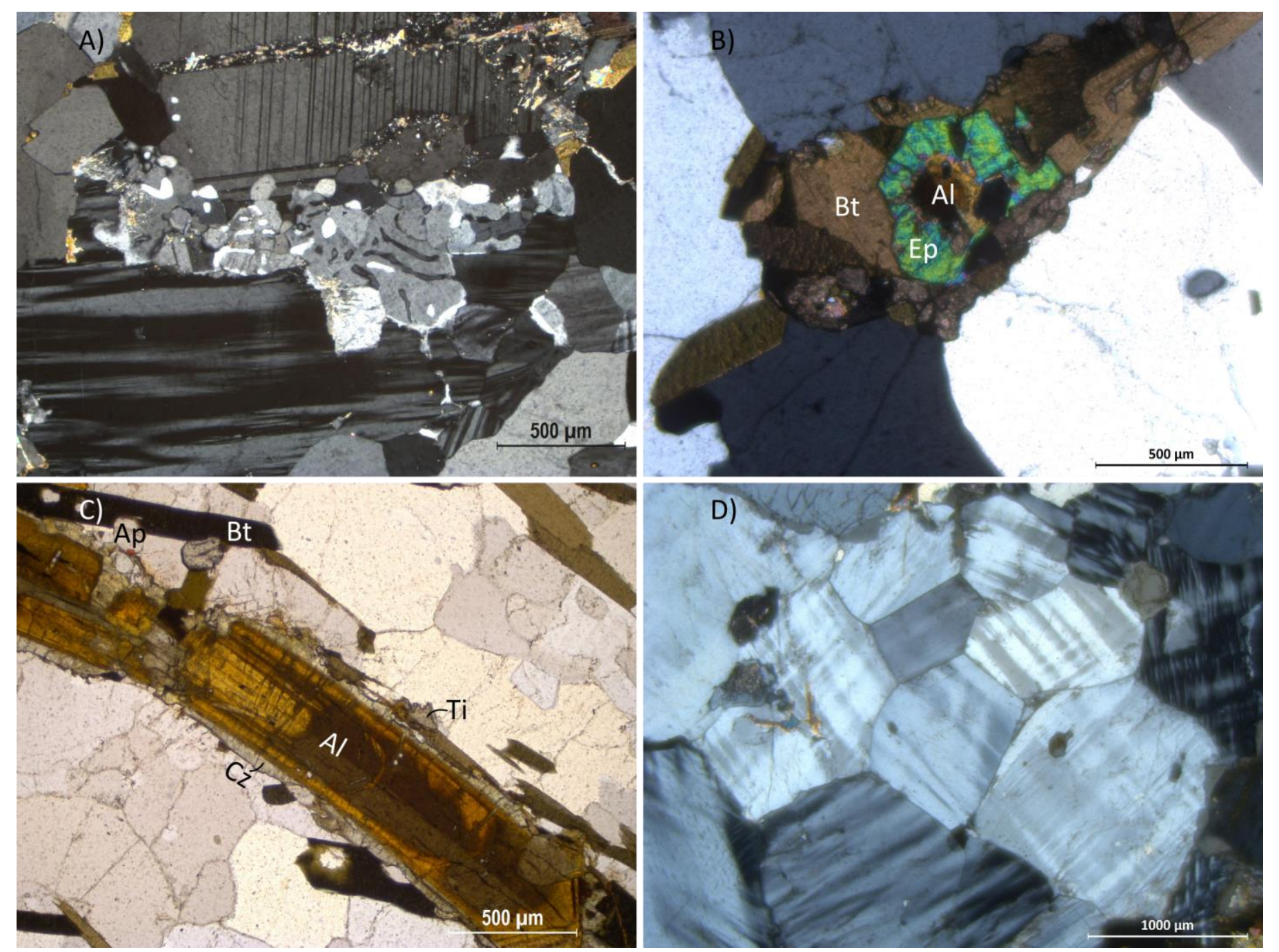

Figura 6 - Fotomicrografias das amostras do Batólito Muniz Freire. A) Amostra PMF-7A: Fenocristais de feldspato alcalino e plagioclásio com mirmequitização no contato entre eles, feldspato alcalino com evidências de recristalização na borda e plagioclásio com sericitização em fratura. B) Amostra PMF-14A: Cristal de epídoto associado a agregado de cristais de biotita e manteando cristal de allanita com geminação simples. C) Amostra PMF-9A: Cristal euhédrico de allanita com evidente zonamento, fraturado e manteado por clinozoisita, associado a cristais de biotita, apatita, titanita. Sem analisador. D) Amostra PMF-24: Feldspato alcalino com subgrãos formados a partir de um único fenocristal que sofreu 


\section{INTERPRETAÇÕES E DISCUSSÃO DOS RESULTADOS}

\subsection{Petrografia}

Os estudos petrográficos das amostras do BMF exibem feições texturais de deformação no estado sólido, que foram superpostas numa trama originalmente magmática. Porém, essas texturas secundárias variam de intensas a incipientes, com algumas amostras sem evidências de deformação, com texturas ígneas preservadas nas zonas de baixa deformação dúctil. A definição mais precisa das condições metamórficas a partir da petrografia fica prejudicada devido à composição quartzofeldspática dessas rochas e à pequena proporção de minerais máficos associados. Contudo, as texturas das tramas de quartzo e feldspatos podem dar indícios das condições a que essas rochas foram submetidas. A ocorrência de textura granoblástica poligonizada a interlobada, por exemplo, definida por cristais de feldspatos, sugerem condições de temperatura mínimas de $600^{\circ} \mathrm{C}$, correspondendo a condições de fácies anfibolito superior até granulito (Stipp, 2002; Passchier e Trouw, 2005). A recristalização total dos cristais de quartzo sugere temperaturas compatíveis com as acima mencionadas. Os cristais reliquiares de quartzo apresentam maclas de deformação do tipo "tabuleiro de xadrez", mostrando uma extinção em setores, caracterizando a atuação de deformação em temperaturas superiores a $600^{\circ} \mathrm{C}$ (Hirth e Tullis, 1992; Kruhl, 1996; Avé'Lallement e Carter, 1999; Stipp, 2002), provavelmente geradas após a fase de resfriamento do corpo

Em várias amostras, independente da deformação, é possível observar feições de textura porfiroclástica que podem ou não estarem modificadas por processos secundários. Porém, há indícios de que essa era a textura original da rocha, com cristais bimodais, sendo os cristais maiores (entre $1 \mathrm{~mm}-5 \mathrm{~mm}$ ) e a matriz com cristais de granulometria $<0,6 \mathrm{~mm}$ a $0,05 \mathrm{~mm}$.

A ausência de fenocristais com feições de deformação assimétricas nas lâminas estudadas sugere que os processos de deformação no estado sólido foram dominados por mecanismos de cisalhamento puro. Porém, outras feições, como cristais com bordas deformadas e evidências de rotação indicam que certas zonas foram sujeitas a processos de deformação por cisalhamento simples. 


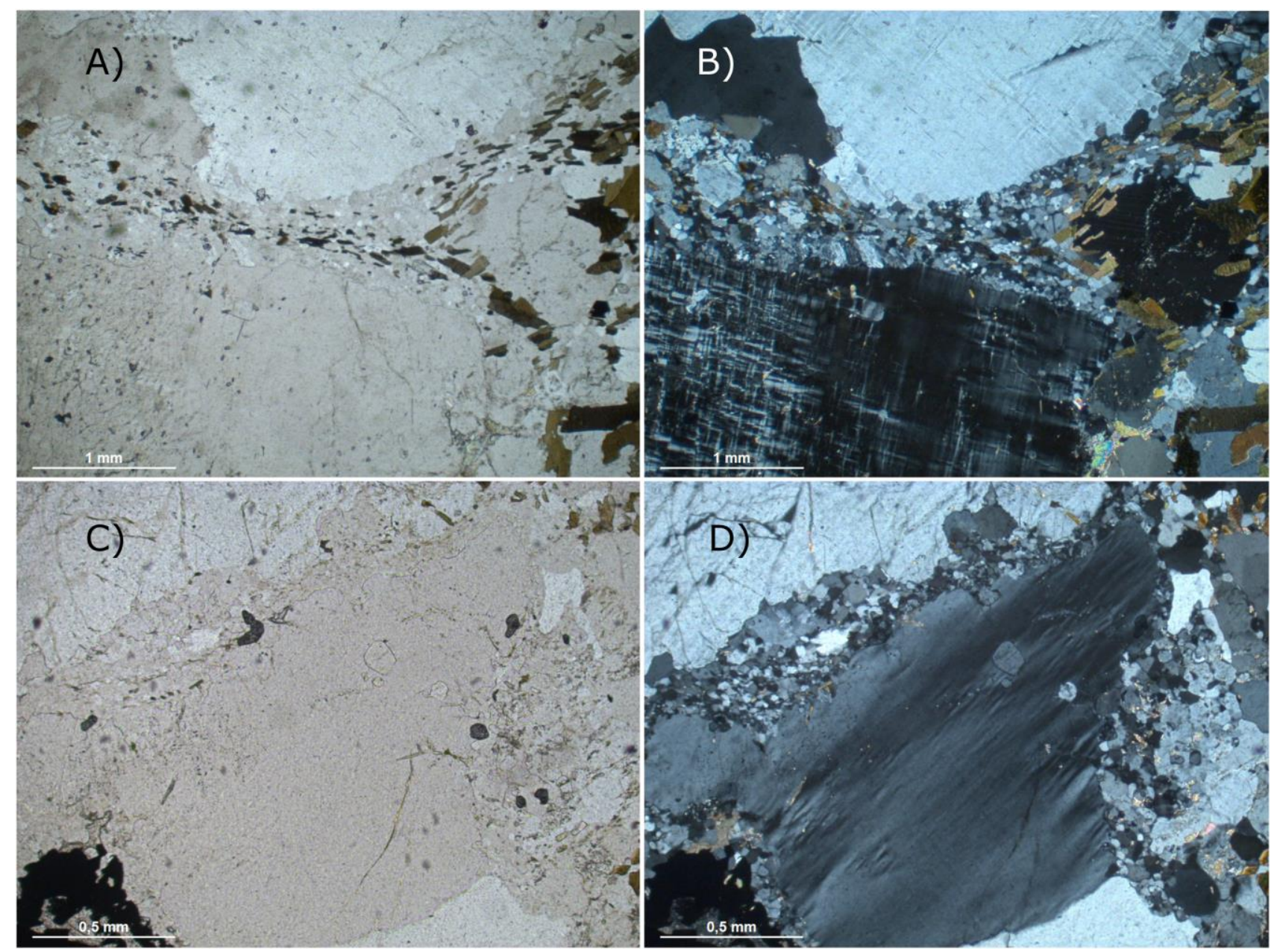

Figura 7 - Fotomicrografias de amostras do Batólito Muniz Freire. A) e B) Amostra STX - 250A. Fenocristais de microclina com fortes evidências de deformação na borda, evidenciando um arranjo granoblástico, onde pequenos cristais de biotita se orientam conforme a deformação. C) e D) feldspato alcalino com borda deformada, formando um arranjo granoblástico semelhante a uma "coroa de grãos". As fotos A) e C) foram obtidas com nicóis paralelos, enquanto em B) e D) foram obtidas com nicóis cruzados. 
As amostras do batólito apresentam composição sienogranítica a tonalitica, exibindo basicamente variações nas proporções entre o feldspato alcalino e o plagioclásio.

As deformações superpostas nas rochas do BMF não modificaram a proporção e composição dos minerais, razão pela qual, considera-se que a moda definida pelos principais minerais observados em lâmina delgada corresponde fundamentalmente a mesma da rocha original.

Os granitos do BMF podem ser classificados como biotita sienogranitos a hornblenda-biotita tonalitos, contendo apatita, zircão, epídoto, allanita, clinozoisita e titanita como principais minerais acessórios.

O uso do termo "ortognaisse", extensamente empregado na literatura para definir o BMF e os demais batólitos classificados como pré- a sin-colisionais do Orógeno Araçuaí, não é usado no presente trabalho, uma vez que o termo gnaisse deve ser reservado para uma rocha que apresenta clara estrutura bandada, o que não ocorre de maneira geral com o que foi observado no campo e nas lâminas delgadas aqui descritas. Ressalte-se a importância do reconhecimento de texturas reliquiares e evidências de processos ígneos preservados na maioria das lâminas analisadas, justificando-se assim o uso do prefixo meta- e mantendo-se o nome-raiz para a classificação do protólito.

\subsection{Observações de Campo}

Os afloramentos estudados do BMF não deixam dúvida com relação a sua grande homogeneidade estrutural. Majoritariamente, predomina uma estrutura foliada, que é definida pelo alinhamento de cristais e agregados de biotita, os quais se dispõem segundo à direção da foliação, evidenciando assim sua cristalização/recristalização controlada por esta estrutura. Quartzo alongado e feldspatos orientados também determinam a foliação, podendo ser observados ribbons de quartzo. Contudo, na porção sul do batólito (ver 7.1.1), é possível observar um bandamento gnáissico marcante que chega a proporções decimétricas, com separação de bandas claras ricas em minerais félsicos (quartzo, feldspatos e granada), que se alternam com bandas escuras dominadas por minerais máficos (biotita e anfibólio). Esse afloramento com estrutura bandada é restrito à borda sul do corpo, próximo do contato com o Complexo Paraíba do Sul (ver ponto 8). 
Vale notar que o primeiro perfil foi realizado fora dos limites da área mapeada por Signorelli (1993) como granito Muniz Freire. Porém, os afloramentos descritos e as amostras coletadas e analisadas tanto petrográfica como geoquímicamente não deixam dúvida que tais rochas fazem parte do BMF, sugerindo que a sua expressão em área é maior do que tem sido representado nos mapeamentos realizados na região (figura 4).

Na seção norte, realizada no batólito, foi possível observar uma unidade ainda não mapeada na região, que corresponde petrograficamente a um muscovita-biotitaquartzo-plagioclásio xisto que aparece tanto no contato oeste como no contato leste do referido batólito. Esta unidade, pela sua expressão, é mapeável mesmo em escala 1: 100.000, e deve corresponder a uma faixa de milonitos que limita o batólito nessa região e está associada provavelmente com a atividade das zonas de cisalhamentos que controlaram a colocação do mesmo no setor norte. 
Tabela 2 - Composição representativa dos elementos maiores e traços das amostras selecionadas do BMF, obtidos por ICP-OES. Elementos maiores em \% e elementos traços em ppm.

\begin{tabular}{|c|c|c|c|c|c|c|c|c|c|c|c|}
\hline Rocha & \multicolumn{3}{|c|}{ Granodioritos } & \multicolumn{5}{|l|}{ Granitos } & \multicolumn{3}{|c|}{ Microgranitos } \\
\hline $\begin{array}{r}\text { Amostra } \\
\text { Óxidos (\%) }\end{array}$ & PMF-02 & PMF-12 & PMF-14A & PMF-05 & PMF-06 & PMF-09A & PMF-09C & PMF-18 & PMF-26 & PMF-07A & PMF-14B \\
\hline SiO2 & 70,61 & 68,07 & 71,17 & 72,38 & 76,49 & 72,54 & 72,57 & 74,17 & 75,33 & 74,02 & 75,54 \\
\hline $\mathrm{Al} 2 \mathrm{O} 3$ & 14,48 & 15,80 & 14,39 & 14,59 & 11,72 & 13,59 & 13,50 & 13,32 & 12,69 & 13,32 & 13,05 \\
\hline $\mathrm{Fe} 2 \mathrm{O} 3$ & 3,29 & 3,38 & 2,91 & 1,31 & 1,63 & 2,79 & 2,89 & 2,10 & 1,87 & 1,48 & 0,86 \\
\hline $\mathrm{MgO}$ & 0,98 & 0,86 & 0,71 & 0,52 & 0,70 & 0,62 & 0,66 & 0,41 & 0,31 & 0,47 & 0,14 \\
\hline $\mathrm{CaO}$ & 2,46 & 3,31 & 3,11 & 0,83 & 1,04 & 2,03 & 1,98 & 1,84 & 1,34 & 1,59 & 0,86 \\
\hline $\mathrm{Na} 2 \mathrm{O}$ & 3,48 & 3,64 & 3,29 & 2,11 & 2,39 & 3,14 & 3,02 & 2,84 & 2,95 & 2,53 & 2,56 \\
\hline K2O & 3,21 & 3,10 & 2,98 & 5,34 & 4,78 & 4,04 & 4,30 & 4,37 & 4,65 & 5,33 & 6,19 \\
\hline TiO2 & 0,43 & 0,46 & 0,39 & 0,17 & 0,22 & 0,33 & 0,34 & 0,24 & 0,21 & 0,22 & 0,08 \\
\hline P2O5 & 0,04 & 0,12 & 0,10 & 0,02 & 0,03 & 0,10 & 0,11 & 0,07 & 0,06 & 0,05 & 0,03 \\
\hline $\mathrm{MnO}$ & 0,03 & 0,06 & 0,05 & 0,02 & 0,02 & 0,05 & 0,05 & 0,04 & 0,05 & 0,03 & 0,01 \\
\hline $\mathrm{Cr} 2 \mathrm{O} 3$ & $<0.002$ & $<0.002$ & $<0.002$ & $<0.002$ & $<0.002$ & $<0.002$ & $<0.002$ & $<0.002$ & $<0.002$ & $<0.002$ & $<0.002$ \\
\hline LOI & 0,8 & 0,8 & 0,5 & 2,4 & 0,8 & 0,4 & 0,2 & 0,4 & 0,4 & 0,7 & 0,6 \\
\hline Sum & 99,82 & 99,62 & 99,62 & 99,70 & 99,78 & 99,65 & 99,62 & 99,81 & 99,86 & 99,74 & 99,92 \\
\hline \multicolumn{12}{|l|}{ Menores(ppm) } \\
\hline $\mathrm{Ba}$ & 817 & 2260 & 2464 & 1931 & 1377 & 2073 & 2366 & 1007 & 836 & 1603 & 394 \\
\hline Cs & 1,4 & 0,5 & 0,8 & 1,0 & 1,6 & 0,5 & 0,3 & 1,5 & 1,6 & 1,0 & 1,1 \\
\hline $\mathrm{Ga}$ & 21,7 & 16,6 & 13,8 & 15,3 & 14,0 & 11,8 & 11,4 & 13,5 & 13,2 & 12,3 & 13,3 \\
\hline $\mathrm{Hf}$ & 5,6 & 5,6 & 4,9 & 4,7 & 5,1 & 5,4 & 5,6 & 4,0 & 4,0 & 5,0 & 2,4 \\
\hline $\mathrm{Nb}$ & 18,8 & 7,7 & 6,5 & 4,7 & 5,3 & 7,7 & 7,2 & 5,4 & 6,8 & 4,6 & 11,9 \\
\hline $\mathrm{Rb}$ & 114,7 & 52,5 & 50,2 & 122,2 & 152,9 & 64,8 & 66,7 & 101,9 & 125,9 & 104,3 & 124,0 \\
\hline $\mathrm{Sr}$ & 307,3 & 380,0 & 346,4 & 319,2 & 310,1 & 298,3 & 314,3 & 167,3 & 133,1 & 300,5 & 91,4 \\
\hline $\mathrm{Ta}$ & 1,0 & 0,3 & 0,2 & 0,3 & 0,4 & 0,6 & 0,4 & 0,4 & 0,4 & 0,2 & 2,0 \\
\hline Th & 2,2 & 6,5 & 7,0 & 12,5 & 1,5 & 8,5 & 9,0 & 10,3 & 13,7 & 12,9 & 8,1 \\
\hline$U$ & 0,6 & 0,4 & 0,4 & 1,2 & 0,7 & 0,5 & 0,4 & 1,1 & 0,9 & 0,9 & 8,4 \\
\hline $\mathrm{Zr}$ & 211,8 & 250,4 & 208,2 & 165,6 & 182,6 & 228,5 & 234,8 & 158,7 & 135,6 & 164,5 & 63,3 \\
\hline $\mathrm{Y}$ & 5,9 & 12,5 & 11,3 & 5,2 & 2,9 & 14,1 & 14,1 & 13,1 & 21,3 & 5,8 & 24,3 \\
\hline \multicolumn{12}{|l|}{ ETR(ppm) } \\
\hline La & 11,3 & 46,4 & 64,6 & 39,8 & 9,0 & 111,8 & 116,5 & 65,4 & 33,1 & 51,2 & 16,7 \\
\hline $\mathrm{Ce}$ & 22,8 & 108,3 & 121,2 & 86,3 & 15,0 & 170,2 & 149,7 & 136,8 & 77,9 & 101,3 & 33,8 \\
\hline $\mathrm{Pr}$ & 2,38 & 9,49 & 12,14 & 8,31 & 1,63 & 20,91 & 21,11 & 14,96 & 8,44 & 11,51 & 4,00 \\
\hline $\mathrm{Nd}$ & 8,8 & 33,3 & 41,3 & 30,0 & 5,8 & 70,3 & 72,7 & 52,7 & 31,2 & 41,4 & 14,8 \\
\hline $\mathrm{Sm}$ & 1,78 & 4,65 & 5,32 & 4,08 & 0,82 & 8,28 & 8,55 & 7,49 & 5,70 & 5,84 & 3,22 \\
\hline $\mathrm{Eu}$ & 1,32 & 1,52 & 1,48 & 1,15 & 0,76 & 1,55 & 1,49 & 0,97 & 0,88 & 1,89 & 0,40 \\
\hline $\mathrm{Gd}$ & 1,60 & 3,63 & 3,67 & 2,46 & 0,69 & 5,25 & 5,54 & 5,23 & 5,00 & 3,75 & 3,45 \\
\hline $\mathrm{Tb}$ & 0,25 & 0,52 & 0,48 & 0,32 & 0,12 & 0,66 & 0,66 & 0,69 & 0,87 & 0,42 & 0,72 \\
\hline Dy & 1,17 & 2,47 & 2,47 & 1,28 & 0,49 & 2,92 & 2,85 & 3,02 & 4,40 & 1,40 & 4,43 \\
\hline $\mathrm{Ho}$ & 0,18 & 0,45 & 0,40 & 0,16 & 0,09 & 0,47 & 0,49 & 0,48 & 0,76 & 0,17 & 0,79 \\
\hline $\mathrm{Er}$ & 0,56 & 1,38 & 1,27 & 0,42 & 0,26 & 1,54 & 1,40 & 1,30 & 2,11 & 0,50 & 2,39 \\
\hline $\mathrm{Tm}$ & 0,09 & 0,20 & 0,18 & 0,06 & 0,04 & 0,26 & 0,24 & 0,16 & 0,27 & 0,07 & 0,41 \\
\hline $\mathrm{Yb}$ & 0,50 & 1,21 & 1,14 & 0,34 & 0,32 & 1,87 & 1,83 & 1,09 & 1,61 & 0,52 & 2,73 \\
\hline $\mathrm{Lu}$ & 0,10 & 0,19 & 0,16 & 0,06 & 0,06 & 0,29 & 0,28 & 0,15 & 0,23 & 0,07 & 0,41 \\
\hline
\end{tabular}


Tabela 3 - Composição representativa dos elementos maiores e traços das amostras selecionadas do BMF, obtidos por ICP-OES. Elementos maiores em \% e elementos traços em ppm.

\begin{tabular}{|c|c|c|c|c|c|c|c|c|c|c|c|c|c|}
\hline \multirow{2}{*}{$\begin{array}{r}\text { Rocha } \\
\text { Amostra } \\
\text { Óxidos (\%) }\end{array}$} & \multicolumn{6}{|c|}{ Granodiorito/Granito } & \multicolumn{7}{|c|}{ Microgranitos } \\
\hline & STX276 & STX278 & STX274C & STX257 & STX273 & STX265 & STX258A & STX259 & STX277 & STX262C & STX264A & STX260B & STX260A \\
\hline $\mathrm{SiO} 2$ & 67,726 & 71,527 & 71,905 & 72,322 & 73,748 & 74,974 & 75,443 & 76,377 & 78 & 74,704 & 76,448 & 76,787 & 77,196 \\
\hline $\mathrm{Al} 2 \mathrm{O} 3$ & 14,154 & 14,024 & 14,437 & 13,99 & 13,299 & 13,612 & 12,627 & 12,578 & 12,182 & 13,117 & 12,751 & 12,737 & 13,556 \\
\hline $\mathrm{Fe} 2 \mathrm{O} 3$ & 3,57 & 2,671 & 2,987 & 2,344 & 2,223 & 2,364 & 1,225 & 1,063 & 1,102 & 1,124 & 1,179 & 0,746 & 1,368 \\
\hline $\mathrm{MgO}$ & 0,737 & 0,612 & 0,469 & 0,641 & 0,488 & 0,459 & 0,268 & 0,153 & 0,048 & 0,161 & 0,038 & 0,067 & 0,297 \\
\hline $\mathrm{CaO}$ & 3,53 & 2,587 & 1,754 & 2,619 & 2,048 & 2,187 & 1,218 & 0,977 & 0,529 & 1,427 & 0,703 & 0,719 & 1,497 \\
\hline $\mathrm{Na} 2 \mathrm{O}$ & 2,373 & 2,92 & 3,609 & 2,708 & 2,625 & 3,331 & 2,939 & 2,692 & 2,521 & 2,058 & 2,694 & 2,993 & 2,937 \\
\hline $\mathrm{K} 2 \mathrm{O}$ & 1,632 & 2,784 & 3,623 & 3,404 & 3,758 & 2,183 & 4,292 & 4,506 & 4,952 & 5,06 & 4,972 & 4,855 & 4,017 \\
\hline $\mathrm{TiO} 2$ & 0,368 & 0,31 & 0,311 & 0,293 & 0,233 & 0,273 & 0,133 & 0,095 & 0,089 & 0,115 & 0,067 & 0,046 & 0,174 \\
\hline P2O5 & 0,111 & 0,096 & 0,138 & 0,1 & 0,081 & 0,084 & 0,058 & 0,053 & 0,028 & 0,041 & 0,034 & 0,036 & 0,056 \\
\hline $\mathrm{MnO}$ & 0,037 & 0,049 & 0,062 & 0,047 & 0,044 & 0,065 & 0,051 & 0,049 & 0,031 & 0,02 & 0,074 & 0,049 & 0,059 \\
\hline LOI & 0,435 & 0,405 & 0,4 & 0,445 & 0,315 & 0,405 & 0,405 & 0,335 & 0,28 & 0,89 & 0,255 & 0,51 & 0,465 \\
\hline Sum & 94,67 & 97,99 & 99,7 & 98,91 & 98,86 & 99,94 & 98,66 & 98,88 & 99,76 & 98,72 & 99,22 & 99,55 & 100,2 \\
\hline \multicolumn{14}{|l|}{ Menores(ppm) } \\
\hline $\mathrm{Ni}$ & 1,86 & 0,5 & 1,15 & 1,93 & 0,98 & 0,43 & 1,73 & 1,33 & 0,39 & 1,01 & 0,44 & 54,42 & 1,79 \\
\hline Sc & 9,65 & 7,25 & 4,79 & 4,19 & 3,47 & 12,68 & 2,82 & 2,02 & 1,4 & 0,77 & 7,75 & 1,79 & 2,59 \\
\hline $\mathrm{Ba}$ & 540,16 & 1637,4 & 1066,8 & 1468,3 & 1178,3 & 666,44 & 419,23 & 352,4 & 276,82 & 1930,3 & 1016,6 & 26,23 & 457,39 \\
\hline $\mathrm{Ga}$ & 17 & 14,6 & 18,7 & 14,3 & 13 & 14,9 & 12,6 & 13,2 & 13,8 & 11,7 & 14 & 13,4 & 13 \\
\hline $\mathrm{Nb}$ & 8,43 & 8,83 & 18,11 & 5,58 & 5,48 & 8,01 & 6,49 & 6,56 & 5,97 & 2,51 & 5,29 & 5,18 & 5,93 \\
\hline $\mathrm{Rb}$ & 69,4 & 56,2 & 167,4 & 81,1 & 85,9 & 76,8 & 145,6 & 161,7 & 92,2 & 104,2 & 111 & 143,9 & 113,6 \\
\hline $\mathrm{Sr}$ & 262,2 & 255,6 & 141,6 & 274,4 & 197 & 178 & 96,3 & 55,6 & 33,5 & 223,4 & 60,8 & 18,6 & 96,3 \\
\hline Th & 13,1 & 8,72 & 10,03 & 9,17 & 8,65 & 9,45 & 9,39 & 9,61 & 7,34 & 7,6 & 9,63 & 12,36 & 5,5 \\
\hline V & 46,523 & 36,934 & 25,027 & 38,62 & 29,724 & 25,013 & 15,126 & 10,45 & 8,4949 & 15,975 & 6,6538 & 4,0592 & 17,217 \\
\hline $\mathrm{Zr}$ & 182,9 & 171,3 & 310,6 & 108,1 & 99,3 & 132,6 & 73,7 & 68,8 & 149 & 75,2 & 77,2 & 53,9 & 72,5 \\
\hline $\mathrm{Cr}$ & 5,04 & 2,9 & 2,7 & 3,64 & 2,8 & 2,68 & 2 & 1,61 & 1,59 & 1,14 & 2,47 & 2,46 & 4,94 \\
\hline $\mathrm{Pb}$ & 11 & 12,9 & 23,8 & 16,2 & 17,7 & 14,6 & 24,5 & 26,7 & 16,5 & 22,9 & 27,2 & 36,6 & 24,5 \\
\hline $\mathrm{Zn}$ & 50,6 & 41,3 & 38,7 & 31,6 & 28,6 & 38,1 & 24,9 & 20,6 & 34,8 & 12,3 & 24,3 & 11,4 & 25,3 \\
\hline $\mathrm{Y}$ & 13,98 & 12,92 & 28,68 & 14,03 & 8,32 & 18,82 & 14,71 & 12,86 & 16,95 & 4,88 & 45,43 & 26,45 & 8,25 \\
\hline \multicolumn{14}{|l|}{ ETR(ppm) } \\
\hline La & 53,67 & 55,93 & 49,52 & 34,1 & 29,19 & 28,34 & 16,62 & 10,21 & 23,18 & 18,6 & 17,48 & 5,94 & 10,75 \\
\hline $\mathrm{Ce}$ & 104,2 & 107,81 & 100,29 & 60,71 & 44,94 & 60,52 & 36,11 & 18,49 & 63,15 & 32,77 & 38,81 & 14,32 & 19,65 \\
\hline $\mathrm{Nd}$ & 47,39 & 37,46 & 44,2 & 21,57 & 20,88 & 27,29 & 12,32 & 9,37 & 30,62 & 12,07 & 21 & 6,97 & 10,1 \\
\hline $\mathrm{Eu}$ & 1,69 & 1,42 & 1,34 & 1,16 & 1,01 & 1,28 & 0,59 & 0,37 & 0,64 & 0,9 & 0,96 & 0,25 & 0,49 \\
\hline $\mathrm{Yb}$ & 1,08 & 1,28 & 2,02 & 1,42 & 0,81 & 1,3 & 1,53 & 1,47 & 1,69 & 0,54 & 5,16 & 4,15 & 0,94 \\
\hline
\end{tabular}




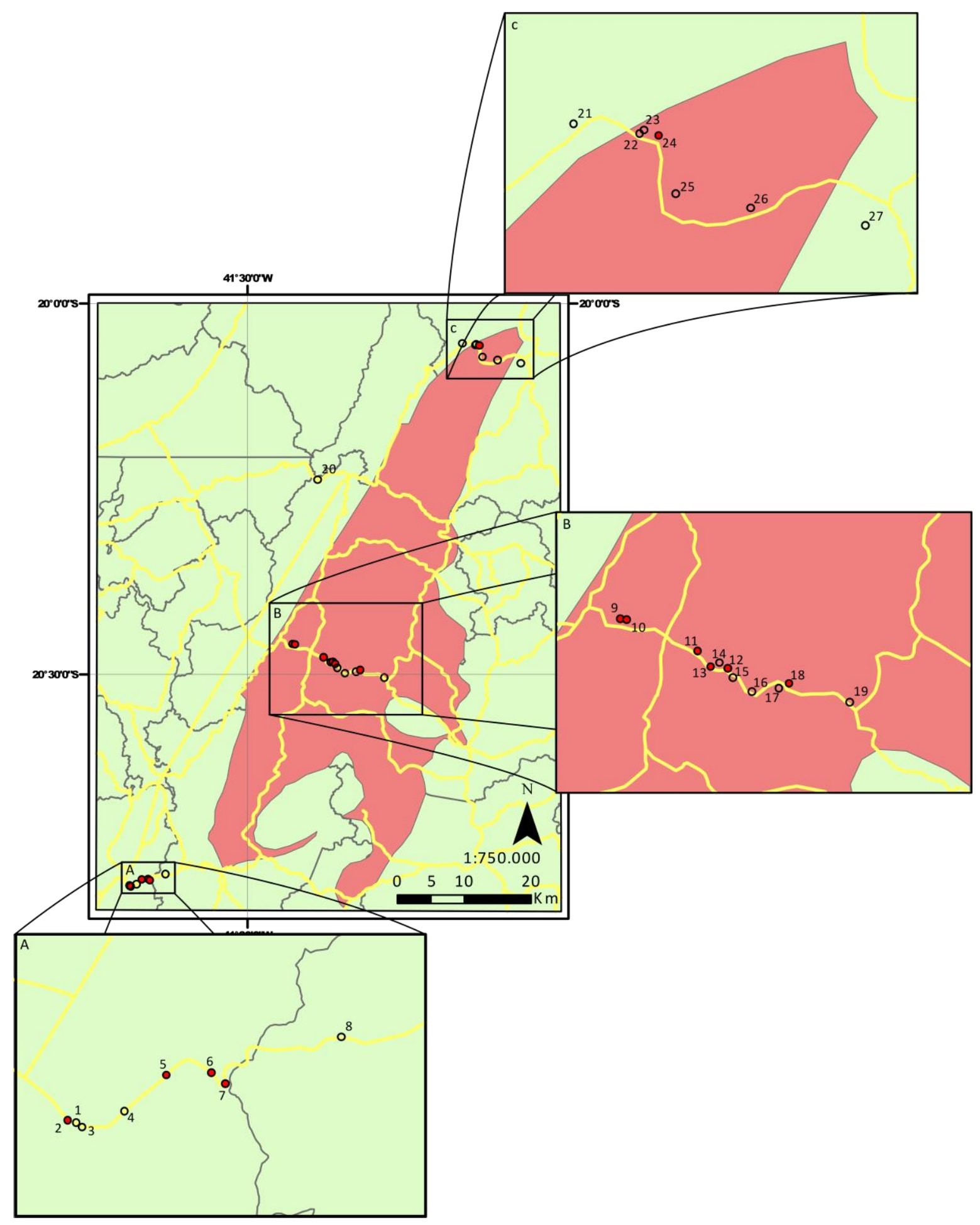

Figura 8 - Seções realizadas no Batólito Muniz Freire durante trabalho de campo. Os pontos em vermelho correspondem aos locais de coleta das amostras para geoquímica e petrografia, esta última apresentada no anexo I. 
A foliação do batólito em mapa (figura 9) mostra-se com disposição subparalela à Zona de Cisalhamento Guaçuí, evidenciando assim o controle exercido por esta estrutura na colocação do mesmo. Contudo, distanciando-se do contato e indo em direção ao centro do corpo, as foliações mantêm-se de alto ângulo, porém assumem uma outra direção que é quase ortogonal à referida zona de cisalhamento, indicando que aí não houve mais um controle da foliação por esta estrutura, mas sim por outro mecanismo. Nota-se também que a foliação se torna cada vez mais incipiente à medida que se afasta da Zona de Cisalhamento Guaçuí, sugerindo que ela tenha sido gerada por outro mecanismo, como por fluxo magmático. Isto é corroborado pelas observações de lâmina, uma vez que não foram registradas feições microestruturais indicativas de rotação de minerais, indicando que a recristalização para o interior do corpo ocorreu sob condições estáticas e sem interferência da atividade da zona de cisalhamento. Em lâmina delgada, a partir de amostras mais distantes da ZC Guaçuí (lâmina PMF-18, p. ex.), observa-se o desenvolvimento de uma foliação incipiente e pouca deformação, reforçando assim a não interferência da referida ZC nesta porção do corpo. Contudo, as falhas assinaladas no mapa de Silva et al. (2004) têm direção semelhante ao das foliações encontradas nesta seção, sugerindo que elas tiveram papel importante na sua nucleação, apesar de não terem sido encontradas evidências de campo que suportem a existência dessas estruturas (figura 9). 


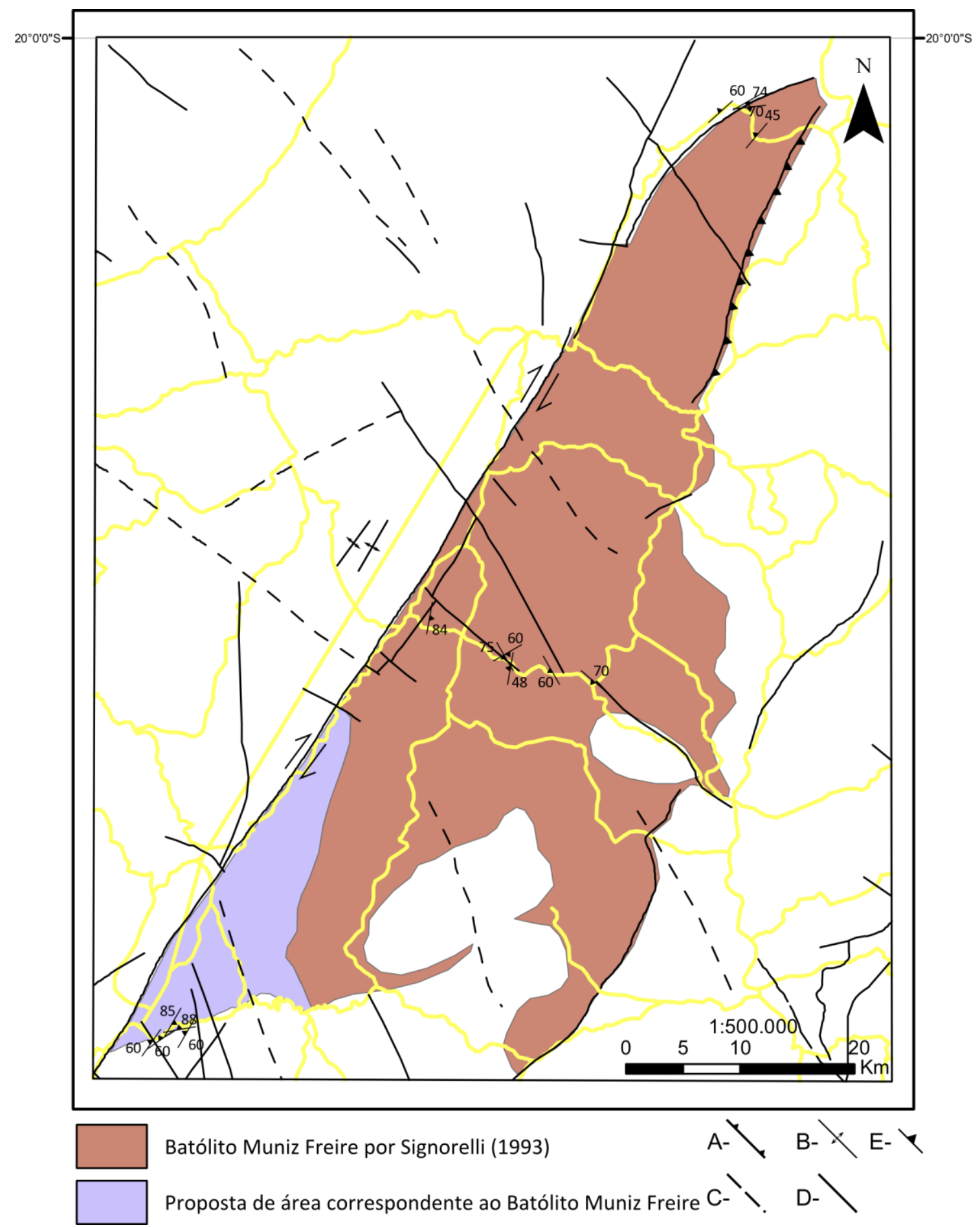

Figura 9 - Mapa com a atitude das foliações obtidas no campo e a interpretação do novo limite do Batólito Muniz Freire com base nas informações de campo. A- Falha inversa ou de empurrão ou Zona de Cisalhamento transpressional; B- Anticlinal ou antiforme normal; C- Falha ou fratura aproximada; D - Zona de $\mathrm{C}$ transcorrente. E- Foliação $\mathrm{S}_{n}$ de estiramento e orientação mineral. 


\subsection{Geoquímica}

Foram selecionadas para análises geoquímicas 24 amostras representativas do BMF, as quais estão relacionadas na tabela 2 e 3 . Nos diagramas utilizados, são feitas comparações com amostras da Suíte Galiléia (Nalini, 1997, Nalini et al. 2005, Narduzzi et al. 2017). Diques micrograníticos estão separados com simbologia distinta.

As rochas estudadas mostram teores de $\mathrm{SiO}_{2}$ entre $67,7 \%$ e $78 \%$, correspondendo a granodioritos à granitos, com teores de $\mathrm{Al}_{2} \mathrm{O}_{3}$ relativamente altos, entre 12,1 e 15,8, típico de rochas peraluminosas. O diagrama de classificação de Middlemost et al. (1994) indica se tratarem de granitos a granodioritos. (Figura 10). O diagrama de saturação em alumina de Shand (1949) (Figura 11), de $\mathrm{Al}_{2} \mathrm{O}_{3} / \mathrm{CaO}+\mathrm{Na}_{2} \mathrm{O}+\mathrm{K}_{2} \mathrm{O}$ versus $\mathrm{Al}_{2} \mathrm{O}_{3} / \mathrm{Na}_{2} \mathrm{O}+\mathrm{K}_{2} \mathrm{O}(\mathrm{A} / \mathrm{CNK}$ vs $A / N K)$, indica o caráter levemente peraluminoso das amostras estudadas (A/CNK entre 1,0 e 1,2), conforme já salientado pelos altos teores relativos de alumina. O diagrama de Le Maître et al. (1989), $\mathrm{SiO}_{2}$ vs. $\mathrm{K}_{2} \mathrm{O}$, classifica essas rochas como cálcico- alcalina alto-K, porém com alguma dispersão, com algumas amostras no campo da série cálcio-alcalina e outras no campo da série shoshonítica (Figura 12). 


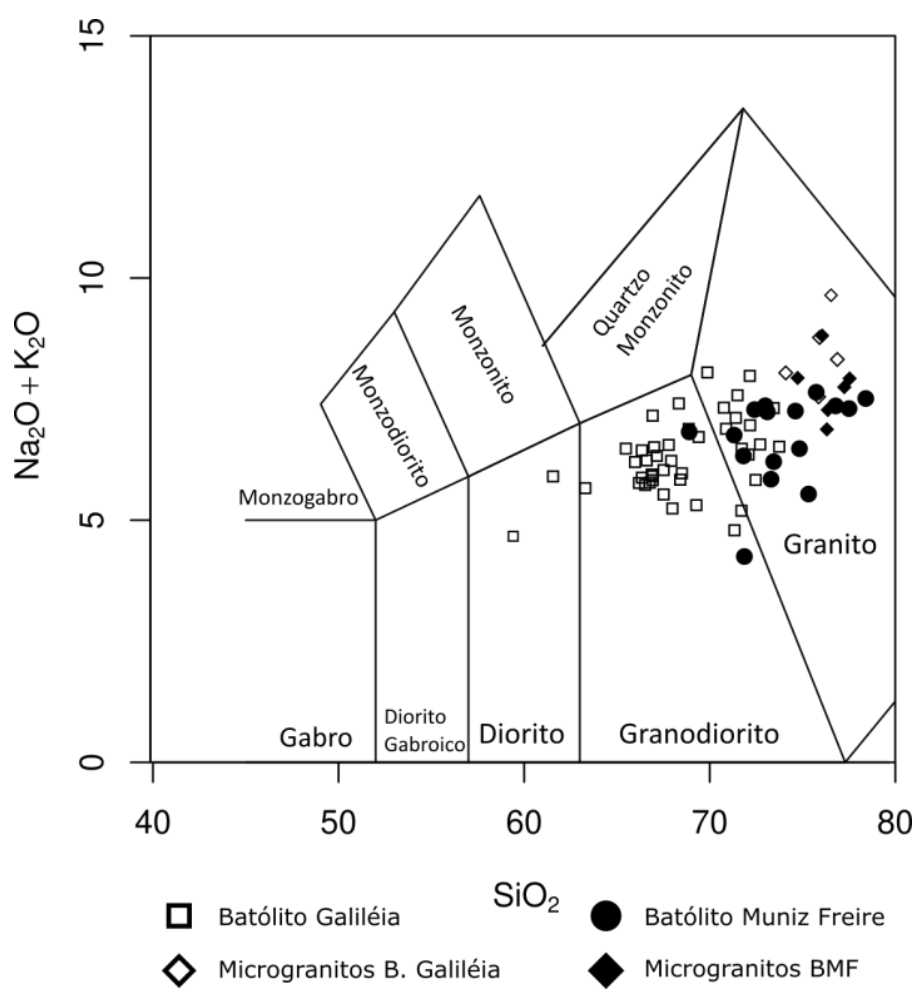

Figura 10 - Diagrama de álcalis versus sílica de classificação de rochas plutônicas segundo Middlemost (1994), apresentando amostras dos batólitos Muniz Freire e Galiléia.

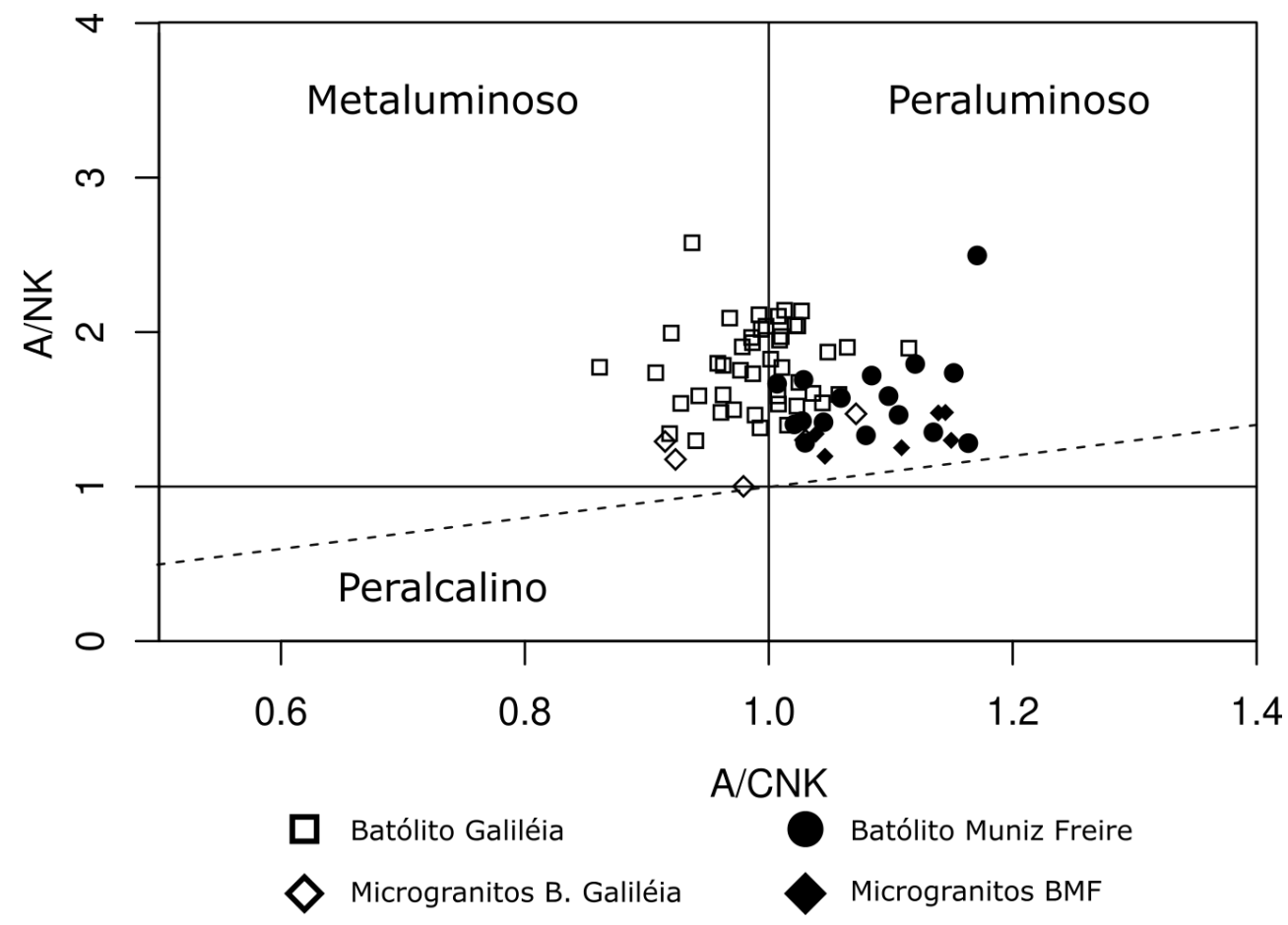

Figura 11 - Diagrama de saturação em alumina segundo. Shand (1949), contendo as amostras dos batólitos Muniz Freire e Galiléia. 


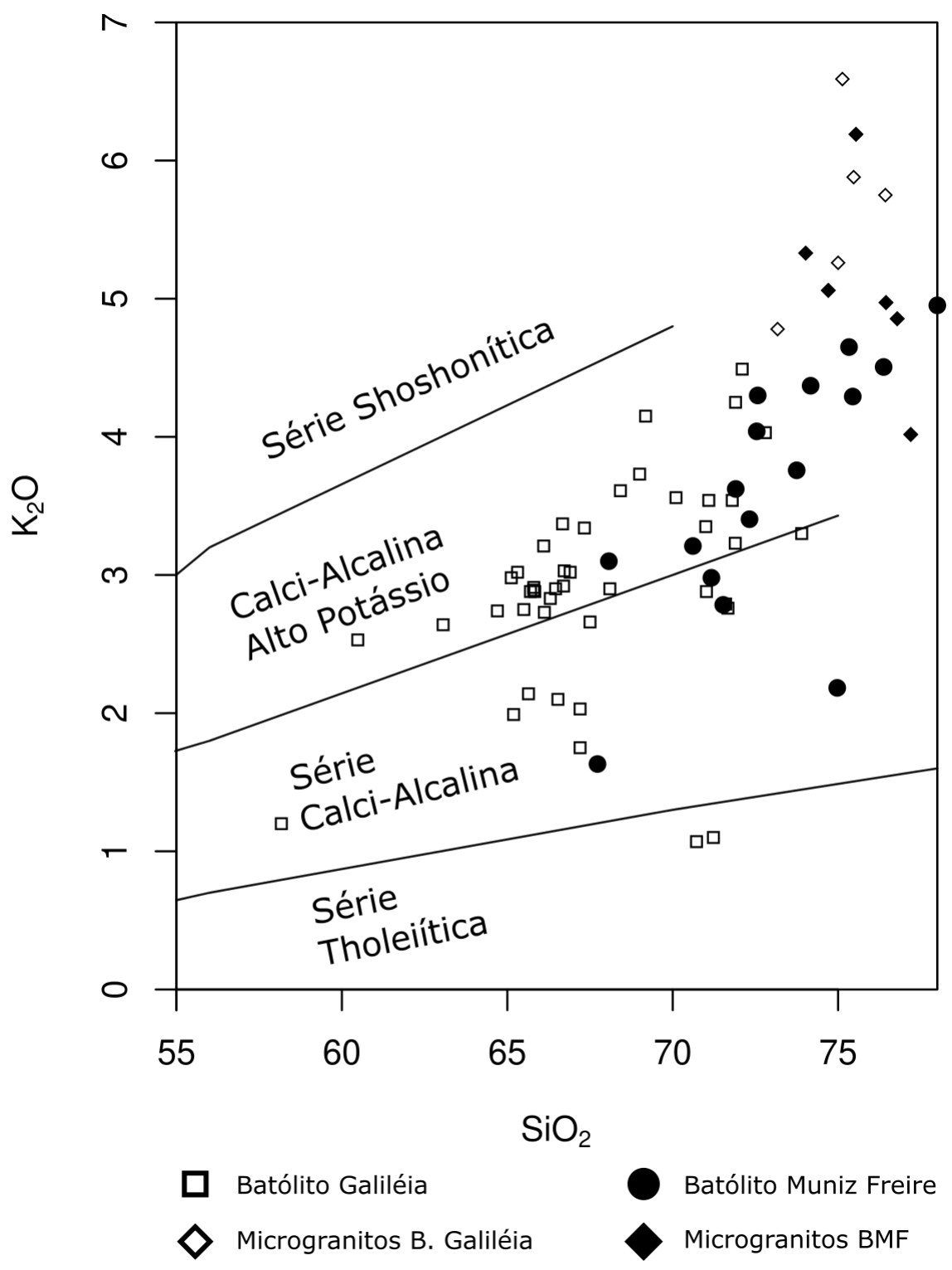

Figura 12 - Diagrama $\mathrm{K}_{2} \mathrm{O}$ versus $\mathrm{SiO}_{2}$ proposto por Le Maitre et al. (1989) para classificação das rochas cálcico-alcalinas, incluindo as amostras dos batólitos Muniz Freire e Galiléia.

O comportamento nos diagramas dos elementos maiores em função sílica, apesar de certa dispersão das amostras para alguns elementos, exibe tendências bem definidas de diferenciação magmática, com a diminuição dos teores de $\mathrm{Al}_{2} \mathrm{O}_{3}, \mathrm{TiO}_{2}, \mathrm{MgO}, \mathrm{FeOT}, \mathrm{CaO}, \mathrm{P}_{2} \mathrm{O}_{5}$ e $\mathrm{Na}_{2} \mathrm{O}$ e aumento dos teores de $\mathrm{K}_{2} \mathrm{O}$. Esse comportamento dos elementos é compatível com rochas comagmáticas evoluídas por mecanismos de diferenciação com cristalização fracionada de biotita, plagioclásio, feldspato alcalino, apatita e minerais opacos (Figura 13). 

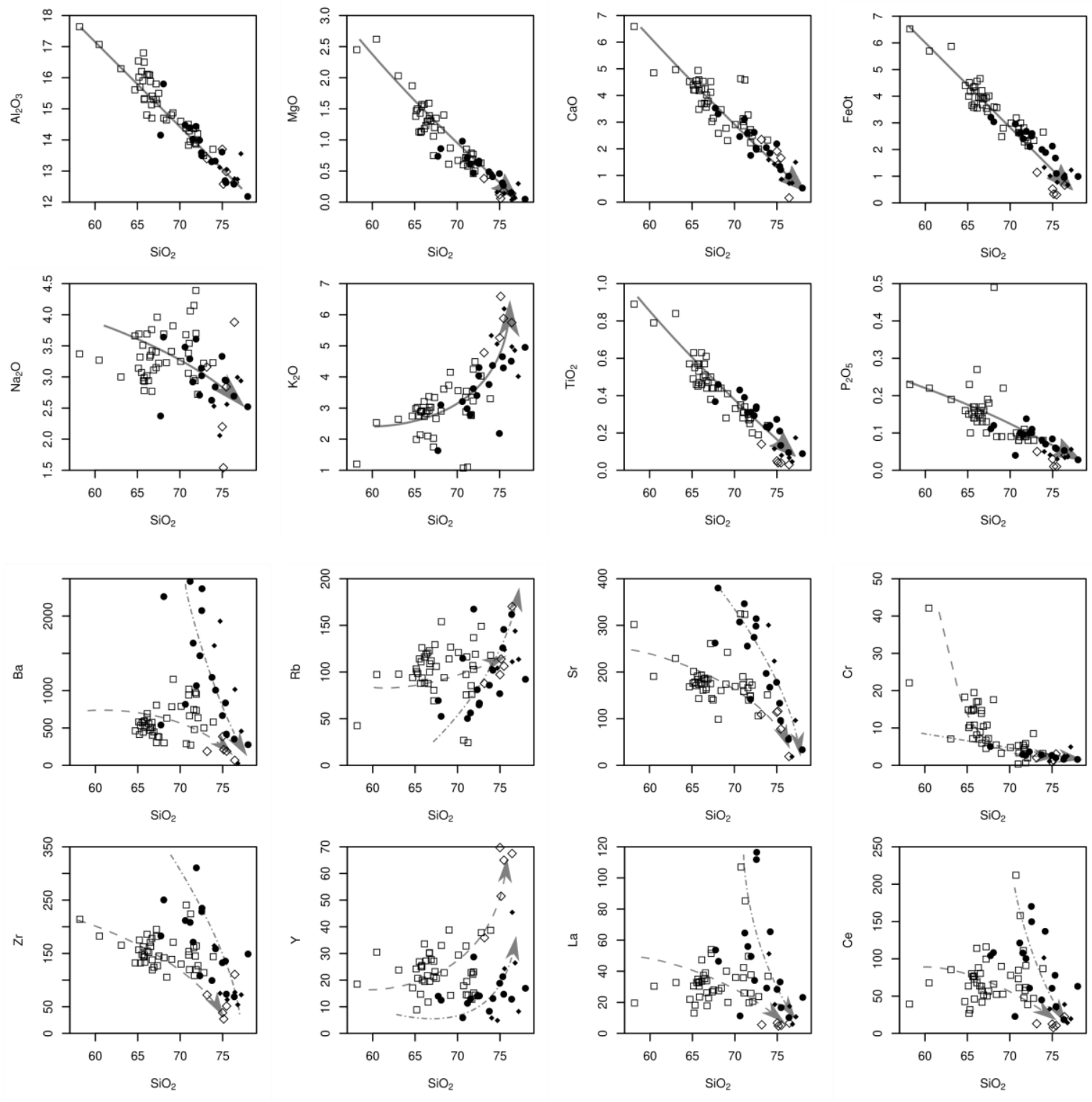

口 Batólito Galiléia

$\checkmark$ Microgranitos B. Galiléia

Batólito Muniz Freire

- Microgranitos BMF

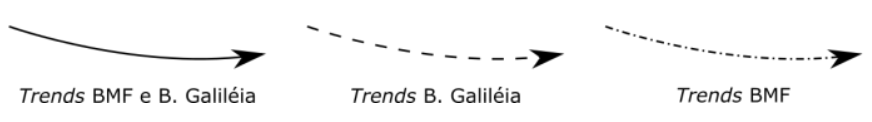

Figura 13 - Diagramas de variação dos elementos maiores (\%), menores e traços (ppm) versus $\mathrm{SiO}_{2} \mathrm{Como}$ índice de diferenciação, incluindo as amostras dos batólitos Muniz Freire e Galiléia e suas respectivas fácies micrograníticas.

Os elementos menores e traços, quando observados em diagramas de Harker, apresentam comportamentos regulares, sugerindo que eles não foram afetados significativamente pelos processos pós-magmáticos que afetaram as 
rochas do BMF. Os teores de Sr e Ba mostram correlação negativa e estão associados com o comportamento do $\mathrm{Ca}$, confirmando assim o fracionamento de plagioclásio. Os conteúdos de $\mathrm{Zr}$ são baixos e mostram diminuição progressiva com a diferenciação, como esperado para magmas graníticos produzidos pela fusão parcial de rochas crustais em temperaturas relativamente baixas (Wilson, 1989).

Os valores de ETR normalizados em relação ao condrito (Nakamura, 1974) (Figura 14) exibem fracionamento acentuado dos ETR leves e anomalia negativa de Eu. Os valores, apesar de certa variação, exibem um bom alinhamento que sugerem rochas co-genéticas. Comparativamente com as amostras do Batólito Galiléia, as do BMF têm maior enriquecimento em ETR leves e uma quantidade semelhante em ETR pesados. O campo delineado pelas amostras do Batólito Galiléia apresenta uma dispersão consideravelmente maior que o das amostras do BMF, porém isso pode ser devido a diferença no número de amostras analisadas. 


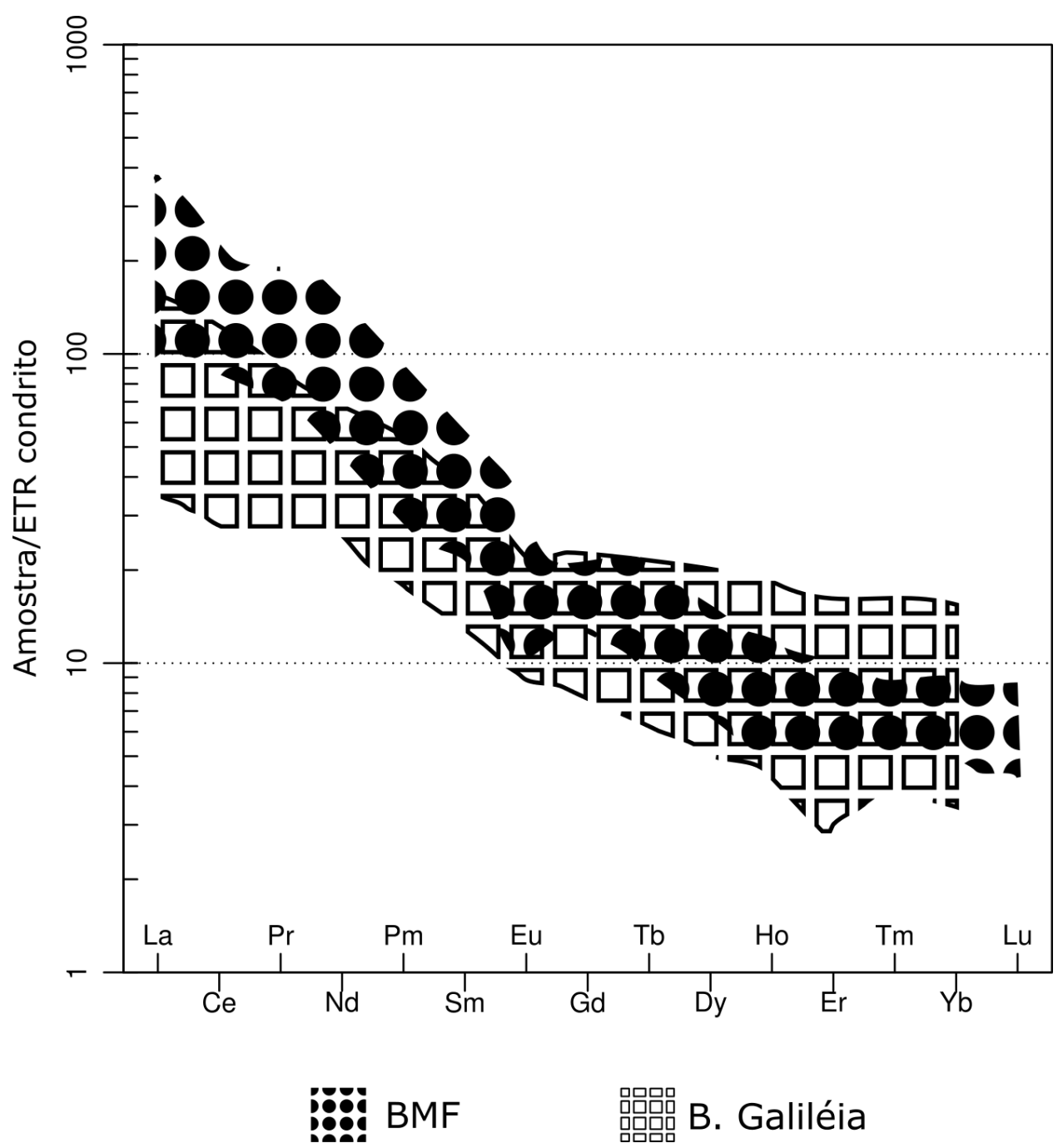

Figura 14 - Elementos Terras Raras do Batólito Muniz Freire normalizados pelo condrito (Nakamura, 1974).

No diagrama $\mathrm{Rb}$ versus $(\mathrm{Y}+\mathrm{Nb})$ (Pearce, 1996), as amostras dos batólitos Muniz Freire e Galiléia correspondem majoritariamente ao campo dos granitos pós-colisionais (GPC) (Figura 15B). Por outro lado, no diagrama de discriminação de ambiente tectônico R1-R2 de Batchelor e Bowden (1985), as amostras estudadas dispõem-se principalmente no campo de granitos sincolisionais, com tendências para os campos pré-colisionais e pós-orogênicos (Figura 15A). 

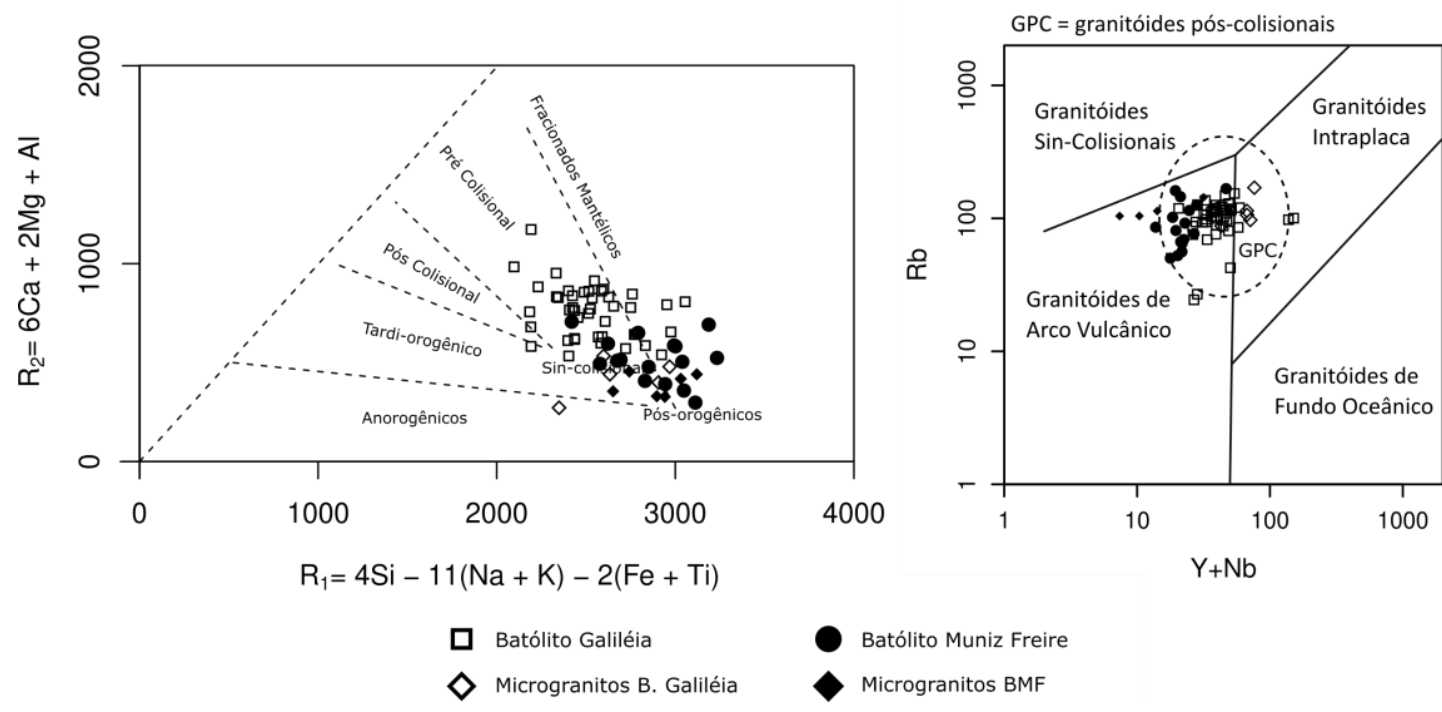

Figura 15 - Diagramas de ambientes tectônicos para as amostras dos batólitos Muniz Freire e Galiléia. A) Diagrama R1 vs R2 (Batchelor e Bowden, 1985). B) Diagrama de Pearce (1996).

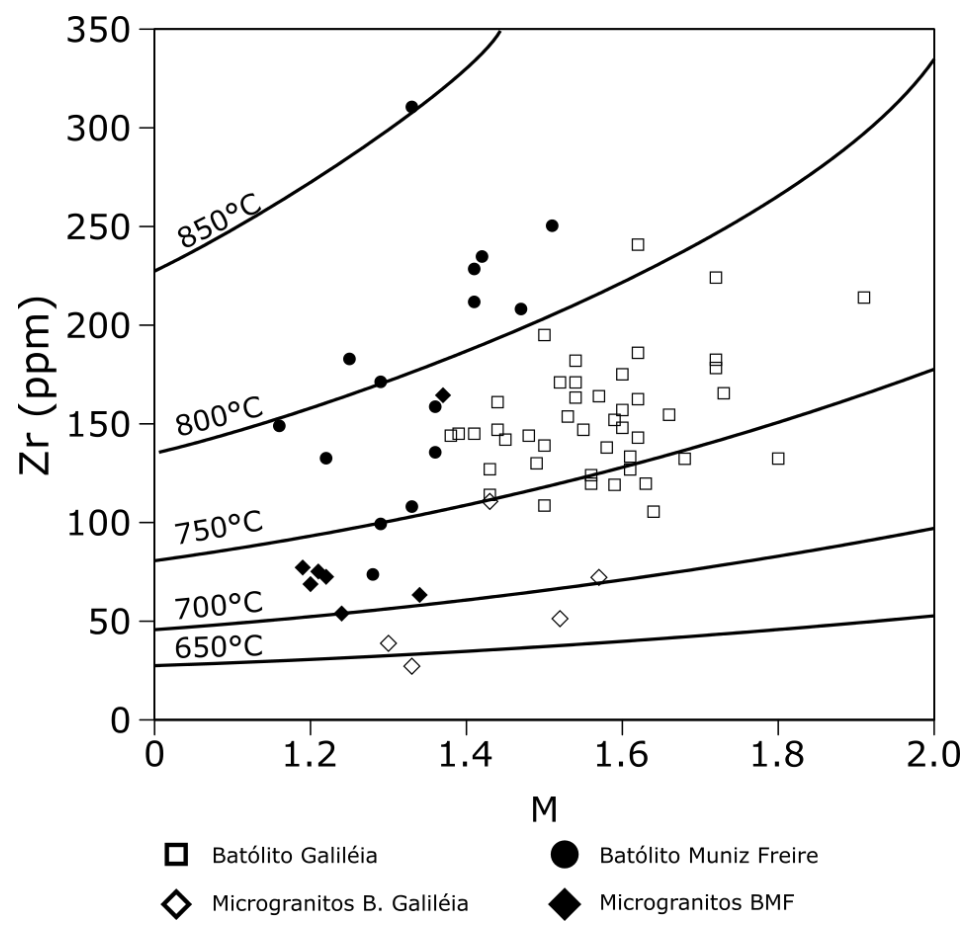

Figura 16 - Temperatura de saturação de zircão dos batólitos Muniz Freire e Galiléia pela calibração de Watson e Harrison (1983). $\mathrm{M}=\left(\mathrm{Na}+\mathrm{K}+\left(2^{*} \mathrm{Ca}\right)\right) /\left(\mathrm{Al}{ }^{*} \mathrm{Si}\right)$. 

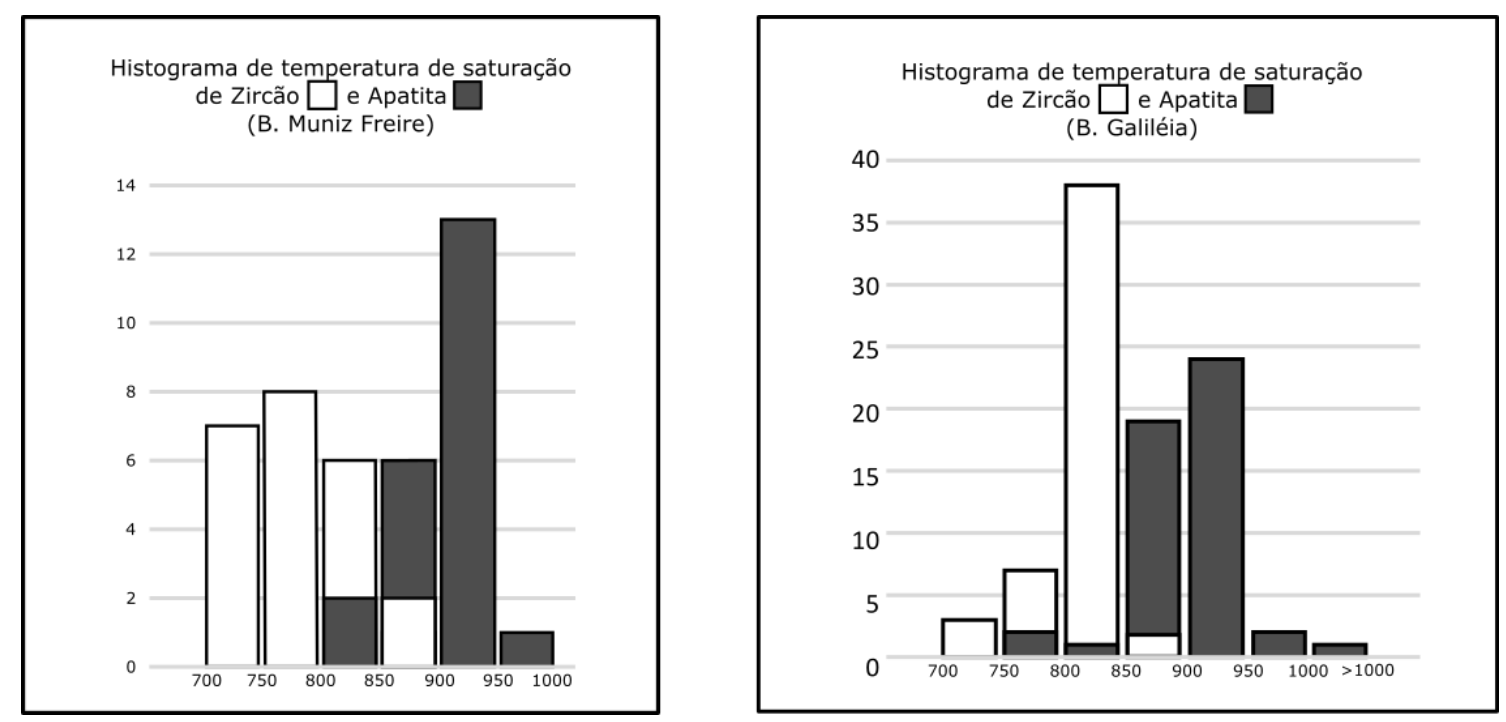

Figura 17 - Histograma com temperaturas de saturação de zircão e apatita dos batólitos Muniz Freire e Galiléia, pela calibração de Watson e Harrison (1983) e Harrison e Watson (1984).

Os dados de temperatura de saturação em zircão e apatita (Figuras 16 e 17, Harrison e Watson, 1983, Watson e Harrison, 1984) indicam temperaturas de saturação de $\sim 725^{\circ} \mathrm{C}$ a $\sim 825^{\circ} \mathrm{C}$ para zircão e $\sim 875^{\circ} \mathrm{C}$ a $925^{\circ} \mathrm{C}$ para apatita no Batólito Muniz Freire. Já para o Batólito Galiléia, os valores são de $800^{\circ} \mathrm{C}$ a $850^{\circ} \mathrm{C}$ e $\sim 875^{\circ} \mathrm{C}$ a $\sim 925^{\circ} \mathrm{C}$, para zircão e apatita, respectivamente. Observa-se que os valores do Batólito Galiléia são estatisticamente melhor definidos do que os do Batólito Muniz Freire, apresentando menor desvio de temperatura de saturação para ambos os minerais. Isso provavelmente se deve ao número de amostras analisadas do Batólito Galiléia ser relativamente maior do que as amostras do Batólito Muniz Freire, propiciando uma análise estatística muito mais significativa. 


\subsection{Discussão}

O BMF é caracterizado por granitoides de caráter marginalmente peraluminosos, com índice de saturação em alumina comparável com a dos granitos tipo-S australianos, cujos valores são sempre acima de 1,0 (704 amostras consideradas), em geral entre 1,1 e 1,2, variando até 1,39 (Chappell e White, 1992). Já os granitos tipo-I apresentam valores $<1,1$, com uma média de 0,990 (1074 amostras consideradas) (Chappell e White, 1992).

Os diagramas de Harker mostram alinhamentos mais ou menos contínuos para as amostras do BMF, mostrando decréscimo dos teores de $\mathrm{Al}_{2} \mathrm{O}_{3}, \mathrm{TiO}_{2}$, $\mathrm{MgO}, \mathrm{FeOT}, \mathrm{CaO}, \mathrm{P}_{2} \mathrm{O}_{5}$ e $\mathrm{Na}_{2} \mathrm{O}$ e aumento dos teores de $\mathrm{K}_{2} \mathrm{O}$, correlação esta que é compatível com processos de diferenciação dominados por cristalização fracionada envolvendo biotita, plagioclásio, feldspato alcalino, apatita e minerais opacos. Vale notar que as amostras do Batólito Galileia exibem uma forte similaridade com as amostras do BMF, apresentando tendências geralmente bem definidas e semelhantes, porém razoavelmente separadas pelo alto teor de sílica das amostras do BMF e o teor médio das amostras do Batólito Galileia. O comportamento relativamente regular dos elementos menores e traços sugere que eles não foram modificados significativamente pelos processos pósmagmáticos que afetaram as rochas do BMF. Em comparação com as amostras do Batólito Galileia, os elementos menores e traços se comportam como o esperado para corpos magmáticos geograficamente separados, mostrando tendências distintas entre os batólitos em todos os casos. Porém, mesmo com tendências diferentes, acompanham as amostras do BMF, com diminuição dos teores de $\mathrm{Ba}, \mathrm{Sr}$, $\mathrm{Zr}$, La e Ce e com aumento dos teores de $\mathrm{Rb}$ e $\mathrm{Y}$, sugerindo uma evolução semelhante para a maior parte das fases minerais.

O fracionamento dos ETR leves observado nas rochas do BMF pode ser explicado pela cristalização precoce no magma de minerais acessórios, tais como apatita, zircão e allanita. As anomalias negativas em Eu, observadas na maioria das amostras, exceto nos diques, são compatíveis com o fracionamento de plagioclásio. Por outro lado, a presença de anomalias positivas de Eu, em algumas das amostras estudadas, sugere que a geração do magma se deu com envolvimento de processos de fusão parcial, segundo o modelo de White e 
Chappell (1977) e Chappell et al. (1987). Além disso, o enriquecimento dos ETR leves em relação aos ETR pesados sugere uma importante participação crustal na evolução das rochas do batólito. Comparativamente ao Batólito Galiléia, o BMF aparenta ser mais enriquecido em ETR leves e igualmente enriquecido em ETR pesados, sugerindo que a participação crustal na evolução do BMF deve ter sido mais intensa do que no Batólito Galiléia.

As temperaturas de saturação de zircão e apatita indicam que o magma que deu origem ao batólito iniciou sua cristalização em temperaturas relativamente altas para magmas graníticos, o que sugere uma fonte de calor intensa durante a geração do magma primário e um longo período de resfriamento para o mesmo.

\subsection{Química Mineral}

\subsubsection{Granada}

\subsubsection{Granada no Batólito Muniz Freire}

Foram realizados dois perfis de análises borda-centro-borda em cristais de granada presentes na amostra PMF-9B, correspondente a um monzogranito. No primeiro, que para referência será denominado Gr1 (Figura 18A), foram realizados 20 pontos de análise e no segundo, Gr2 (Figura 18B), 17 pontos de análise. 

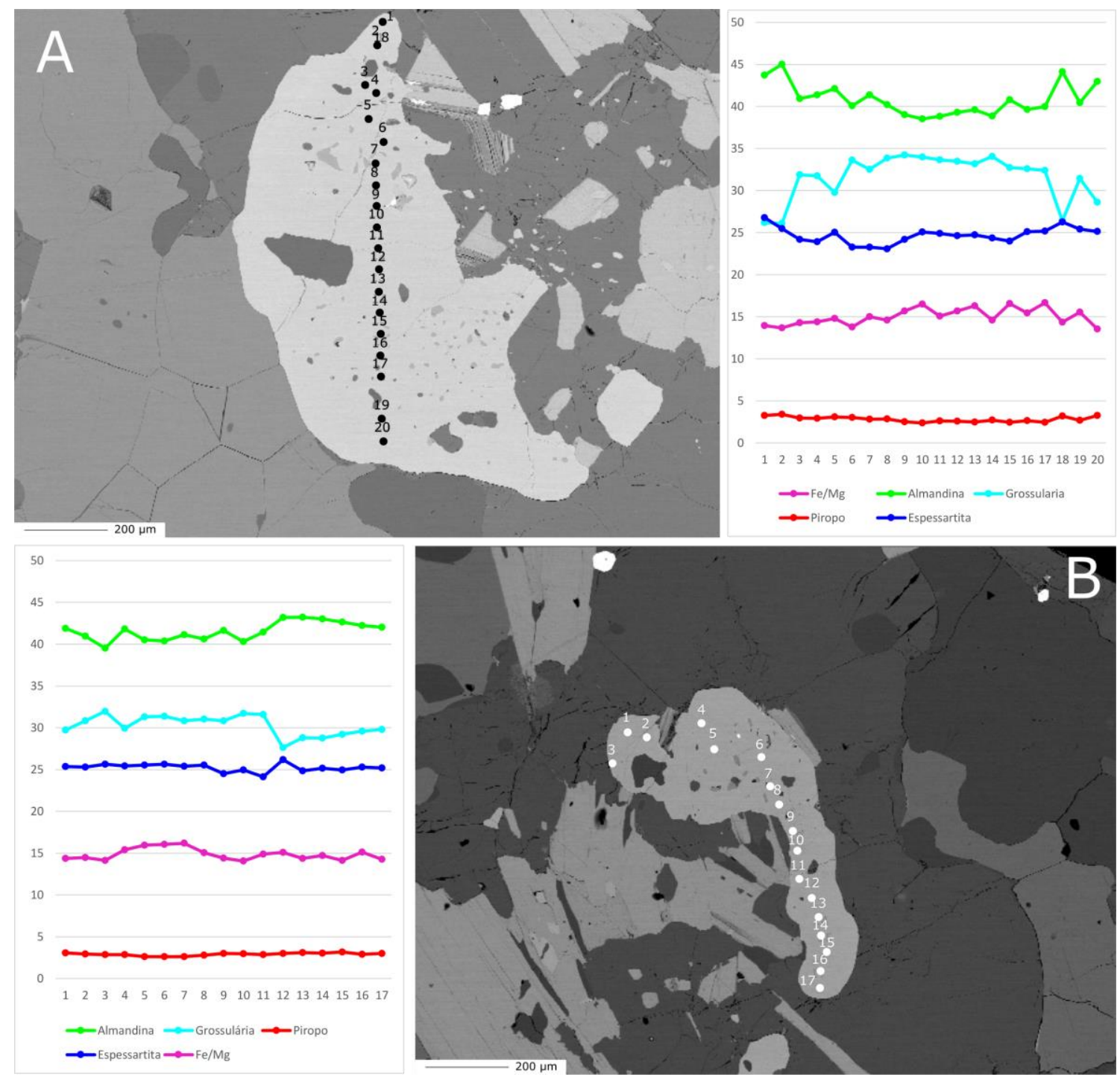

Figura 18 - Fotomicrografias e gráficos composicionais de perfis de análise de granada. Os números se referem aos pontos analisados. A) 20 pontos analisados em Gr1. Ao lado, o gráfico referente a essas análises. B) 17 pontos analisados em Gr2. Ao lado, gráfico referente a essas análises.

As análises de cristais de granada presentes na tabela 4 indicam que ambas apresentam mais de $95 \%$ de sua composição correspondendo a uma solução sólida de almandina+grossulária+espessartita, com baixo teor em piropo $(<4 \%$ molar) e teor relativamente alto de espessartita (24-27\% molar). Apenas duas amostras coletadas do BMF (PMF-9B e PMF-11B, esta última correspondendo à um dique félsico cortando o corpo principal) apresentam granada, com poucos cristais de até $1 \mathrm{~mm}$. Os cristais são xenomórficos, bordas claramente corroídas ou sobrecrescidas e inclusões de quartzo e plagioclásio. 
Tabela 4.

Análises quantitativas obtidas por WDS de elementos maiores em granada do Batólito Muniz Freire.

\begin{tabular}{|c|c|c|c|c|c|c|}
\hline Cristal & Gr1 & & & Gr2 & & \\
\hline Ponto & 1 & 10 & 20 & 1 & 9 & 17 \\
\hline $\mathrm{SiO}_{2}$ & 37,01 & 37,52 & 37,11 & 37,18 & 37,4 & 37,21 \\
\hline $\mathrm{TiO}_{2}$ & 0 & 0,15 & 0,09 & 0,06 & 0,11 & 0,10 \\
\hline $\mathrm{Al}_{2} \mathrm{O}_{3}$ & 20,24 & 20,85 & 20,74 & 20,35 & 20,64 & 20,74 \\
\hline $\mathrm{FeO}$ & 19,59 & 17,33 & 19,43 & 18,89 & 18,92 & 18,76 \\
\hline $\mathrm{MnO}$ & 11,32 & 10,92 & 10,88 & 10,77 & 10,56 & 10,9 \\
\hline $\mathrm{MgO}$ & 0,79 & 0,59 & 0,80 & 0,74 & 0,74 & 0,74 \\
\hline $\mathrm{CaO}$ & 9,15 & 11,71 & 10,22 & 10,34 & 10,84 & 10,24 \\
\hline $\mathrm{Fe} / \mathrm{Mg}$ & 13,96 & 16,51 & 13,55 & 14,37 & 14,42 & 14,26 \\
\hline Almandina & 43,20 & 38,51 & 42,42 & 41,43 & 41,25 & 41,97 \\
\hline Andradita & 1,16 & 0 & 1,25 & 1,07 & 1,00 & 0,13 \\
\hline Grossulária & 25,91 & 33,99 & 28,25 & 29,39 & 30,51 & 29,75 \\
\hline Piropo & 3,24 & 2,38 & 3,23 & 3,02 & 2,98 & 3,00 \\
\hline Espessartita & 26,48 & 25,08 & 24,83 & 25,08 & 24,27 & 25,14 \\
\hline Uvarovita & 0,01 & 0,03 & 0 & 0 & 0 & 0 \\
\hline
\end{tabular}

Ambas as granadas analisadas apresentam composição semelhante, com alguma variação borda-centro, principalmente com relação aos teores de grossulária (Grs\%) e almandina (Alm\%) e pequena variação em espessartita (Sps\%), formando um perfil em sino normal para a variação cálcio-aluminosa e em sino invertido para a variação ferro-aluminosa. Do centro para a borda, Gr1 apresenta uma variação em Alm\% de 38,5\% a 44,5\%, enquanto Gr2 apresenta variação de $39,6 \%$ a 43,7\%. A Grs\% varia, ainda do centro em relação à borda, de $34,1 \%$ a $25,7 \%$ para a $\mathrm{Gr} 1$ e $31,8 \%$ a $26,1 \%$ para a $\mathrm{Gr} 2$. A Sps\% apresenta pequena variação de 22,9\% a 26,5\% para a $\mathrm{Gr} 1$ e 24,0\% a 26,0\% para a $\mathrm{Gr}$. Os valores de piropo e andradita são constantemente baixos, não superando a $4 \%$.

\subsubsection{Comparações}

Dentre os principais tipos de granitos interpretados como pertencentes ao estágio pré-colisional, o BMF e o Batólito Galiléia têm sido usados para comparação por diversos autores, inclusive neste trabalho. Narduzzi et al. (2017) 
realizaram análises em granada em rochas do Batólito Galiléia e compararam seus resultados com experimentos de cristalização e ocorrências naturais de corpos graníticos de outras regiões do mundo, concluindo que os modelos atuais explicam apenas parcialmente sua composição. Comparando os resultados de Narduzzi et al. (2017) com os resultados obtidos para amostras do BMF, notase que ambos possuem composições virtualmente idênticas (figura 20B), bem como as composições de granadas dos granitoides de Bushy Point, Alaska, EUA (Zen e Hammarstrom, 1984). Análises de granada de metagranitos do Orógeno Dabie-Sul (Xia et al. 2012) também forneceram resultados semelhantes aos dos corpos acima. Portanto, afim de discutir a composição relativamente incomum das granadas do BMF, especialmente seu alto teor de Sps\% e Grs\%, essas serão comparadas as granadas analisadas pelos autores acima mencionados, considerando os corpos e suas características principais.

\subsection{Batólito Galiléia}

Narduzzi et al. (2017), em estudo sobre o Batólito Galiléia, identificaram a presença de granadas magmáticas, compondo até $2 \%$ da rocha. Os cristais contêm comumente fraturas, com formas variando de anédrica/esqueletal a subédrica/euédrica, podendo conter ou não inclusões de quartzo, plagioclásio, titanita, epídoto ou biotita, minerais presentes na composição modal original da rocha (Figura 20). Ocorrem pseudomórfos de granada compostos por quartzo+plagioclásio ou biotita, evidenciando reações de substituição complexas.

Em sua comparação com experimentos de cristalização de granada e dados compilados de diversos autores de ocorrências naturais, Narduzzi et al. (2017) notaram que a composição da granada do Batólito Galiléia é diferente do esperado para granada de rochas vulcânicas e graníticas, tanto aquelas oriundas de magmas peraluminosos como de magmas meta-aluminosos, sendo a granada do referido batólito mais pobre em piropo (Pir\%) e mais rica em Grs\% do que as das ocorrências naturais e dos experimentos. Especificamente, os experimentos realizados por Schmidt (1993) a $650^{\circ} \mathrm{C}$ e pressões de 20,0 a 26,0 Kbar mostram resultados relativamente próximos à composição de alguns cristais de granada do Batólito Galiléia, porém com Sps\% muito baixo comparativamente (Figura 19). 


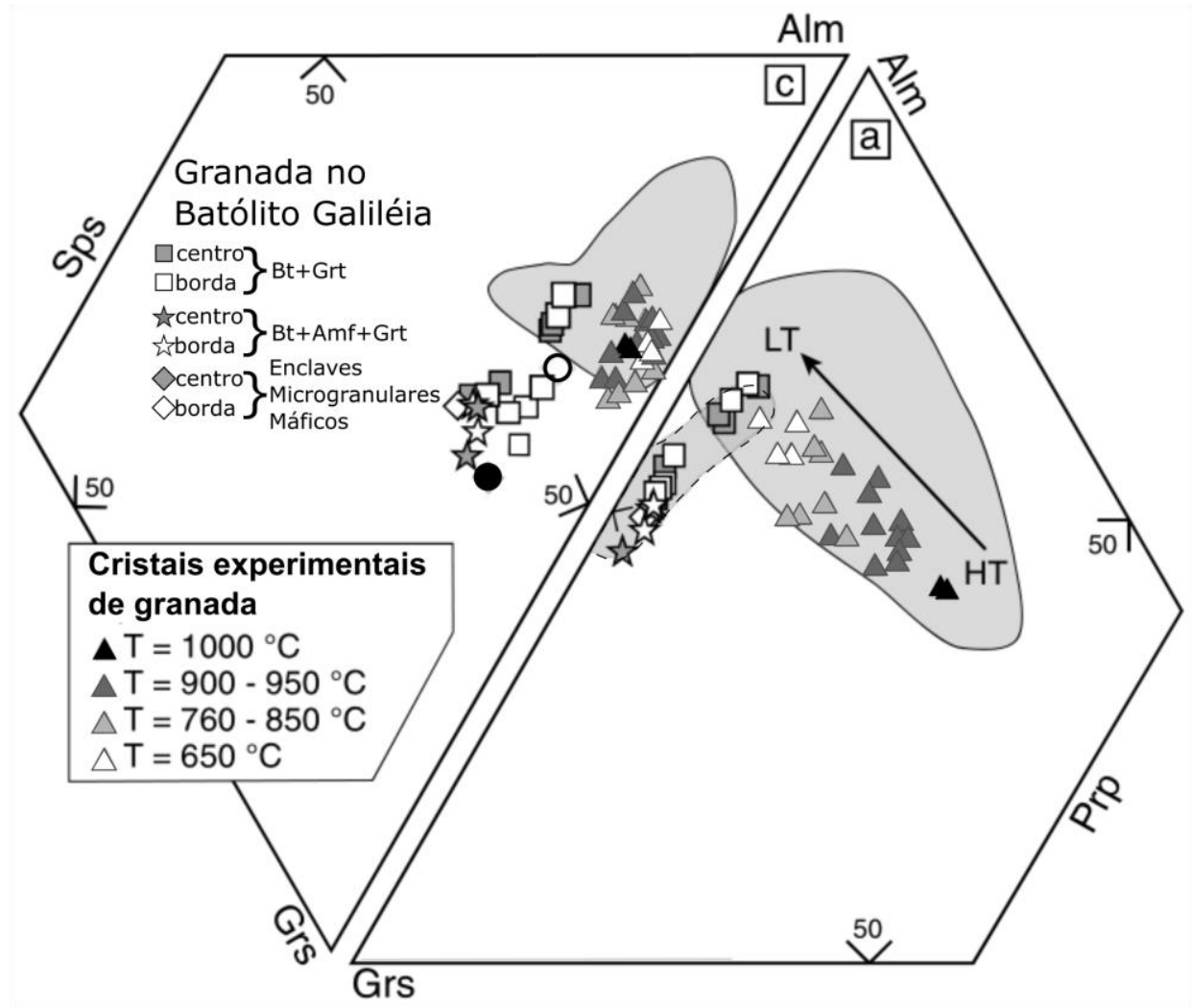

Figura 19 - Comparação entre granada do Batólito Galiléia (quadrados, estrelas, losangos), experimental (triângulos) e natural (círculos e campos). Os dados experimentais correspondem a granada em equilíbrio com magmas metaluminosos e levemente peraluminosos. O campo pontilhado e os círculos (cheios e vazios) são amostras de granada do Tonalito Bushy Point. A seta aponta para o trend de alta temperatura (HT) para de baixa temperatura (LT). O campo cinza corresponde ao das amostras naturais. Retirado de Narduzzi et al. (2017).

Os perfis de análises de granada mostram um aumento de Grs\% nas bordas em relação ao centro, com uma redução espelhada de Alm\%. A composição em Sps\% e Pir\% permanece praticamente constante, exibindo pouquíssima variação (Figura 20B). Esse perfil se modifica quando a granada está inclusa em enclaves máficos (Figura 20C), sendo nesse caso reabsorvida totalmente devido à instabilidade composicional e de temperatura. Os autores interpretam os baixos valores de Pir\% como resultantes da baixa temperatura de cristalização, já que os experimentos de cristalização de granada demonstram que Pir\% aumenta com a temperatura, sendo acompanhados por uma redução em Alm\%. Porém, essa relação sozinha não explica os altos valores de Sps\% e Grs\%. Os experimentos conduzidos por Alonso-Peres (2009), isoladamente, 
evidenciam que a Grs\% pode aumentar com o resfriamento do magma em pressões de aproximadamente $12 \mathrm{kbar}$, embora essa variação não tenha efeito relevante em Sps\%. Narduzzi et al. (2017) recorrem às inclusões para explicar os altos teores concomitantes de espessartita e grossulária. Epidoto magmático e quartzo são inclusões importantes nos cristais de granada e, como demonstrado em experimentos por Schmidt e Thompsom (1996), estes minerais, em sistemas graníticos metaluminosos, começam a se cristalizar em temperaturas próximas de $700^{\circ} \mathrm{C}$ e $655^{\circ} \mathrm{C}$. Isso sugere que os cristais de granada foram produzidos por um processo de dissolução e recristalização em que eles reagiram e se reequilibraram continuamente com um fundido em constante evolução para temperaturas mais baixas. Esse processo explicaria não só os altos valores de Grs\%, como também os altos valores de Sps\% pois, como demonstrado por Miller e Stoddard (1981), processos de diferenciação podem enriquecer o magma em manganês, favorecendo a formação de granada com altos teores em espessartita.

\subsection{Tonalito Bushy Point}

Narduzzi et al. (2017) citam o artigo de Zen e Hammarstrom (1984) realizado no Pluton Tonalítico de Bushy Point, Alaska, EUA, e notam que a granada ali descrita possui composição muito semelhante à composição da granada do Batólito Galiléia (Figura 19). O Pluton de Bushy Point foi datado pelo método K-Ar em hornblenda com idade de 89,6 \pm 2,7 Ma e biotita com idade de $82,3 \pm 2,5 \mathrm{Ma}$ (Smith e Diggles, 1981). A granada ocorre como cristais subedrais a euedrais, de cor laranja avermelhada, com cerca de $1 \mathrm{~mm}$ de diâmetro, sendo normalmente manteada por plagioclásio. O plagioclásio possui composição variável de $A_{20}$ a $A_{40}$ (borda-centro), geralmente com feições de intercrescimento com zoisita esqueletal. Outros minerais que compõem a rocha são quartzo, feldspato alcalino (raros), hornblenda, biotita, titanita e epídoto, este último com evidências petrográficas de origem magmática.

Zen e Hammastrom (1984) consideram baixos os valores de Sps\% e Pir\% na granada e aproximadamente equivalentes os de Grs\% e Alm\%. Interpretam o baixo valor de Pir\% como devido à baixa temperatura de cristalização da 
granada, porém sob condições mínimas de pressão de 13 a 15 kbar, de acordo com os experimentos de Green (1972) em andesitos hidratados.
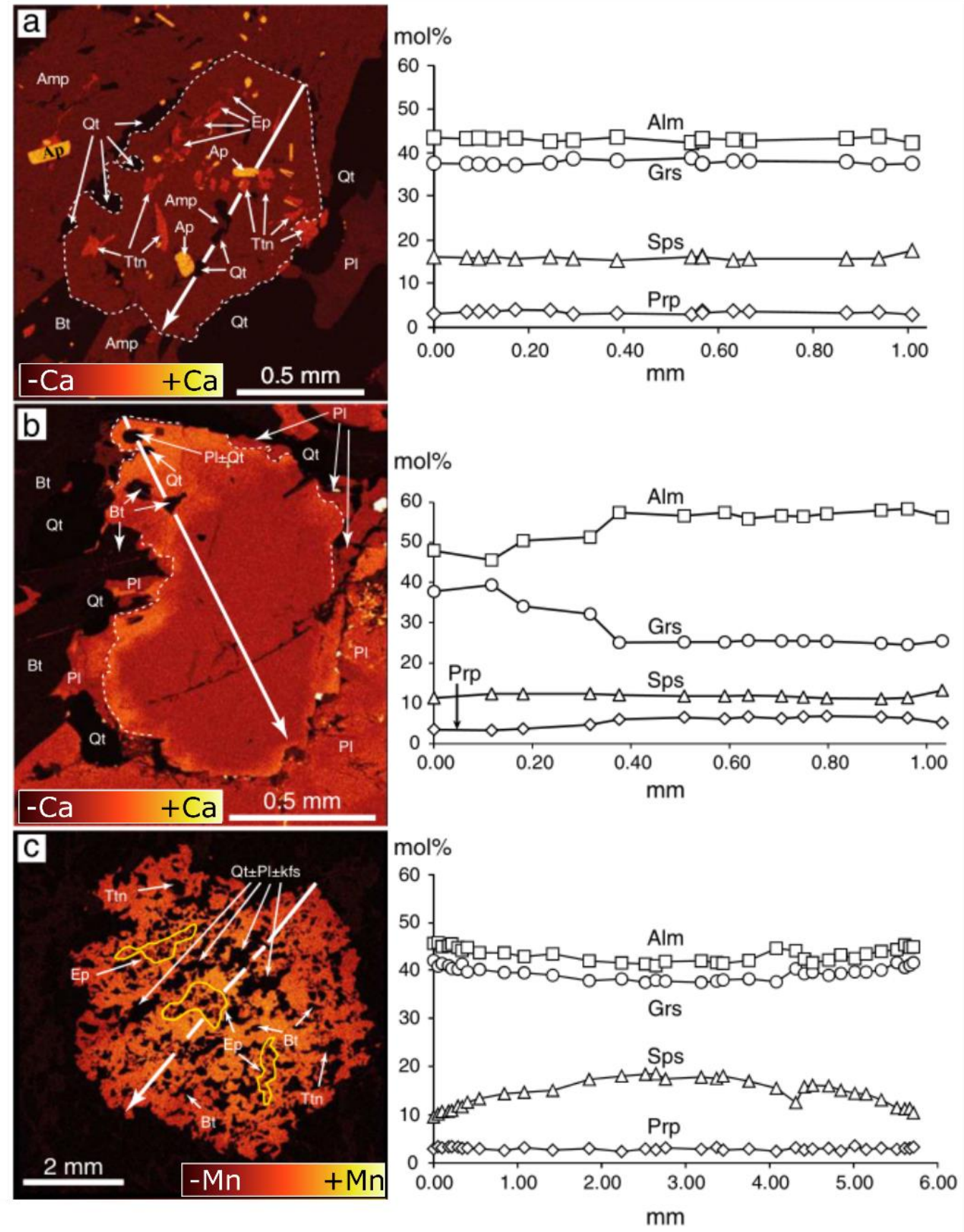

Figura 20 - Perfis e mapas químicos em granada do Batólito Galiléia. A) Granada em biotitaanfibólio-granada-Granitoide. B) Granada em biotita-granada-Granitoide. C) Granada em enclave máfico microgranular. Ao lado das imagens, perfis mostrando o padrão de zoneamento de granada utilizando-se dos principais endmembers. Imagem retirada de Narduzzi et al. (2017) Amp = anfibólio; $\mathrm{Ep}=$ epídoto; $\mathrm{Bt}=$ biotita; $\mathrm{Qt}=$ quartzo; $\mathrm{PI}$ = plagioclásio; Ttn = Titanita; $\mathrm{Ap}=$ apatita. 
As altas pressões sugerem que a granada de Bushy Point teria se formado a aproximadamente $40-50 \mathrm{~km}$ de profundidade, quando o bloco tectônico foi soerguido rapidamente, exumando a rocha com granada sob condições de pressão que, com a temperatura e fugacidade de $\mathrm{H}_{2} \mathrm{O}$ constantes, possibilitou a formação de um fundido. Essa granada teria ficado instável e reagido com o fundido, formando plagioclásio e uma borda mais cálcica, sendo apenas preservada quando manteada por plagioclásio.

\subsection{Metagranitos do Orógeno Dabie-Sul}

Xia et al. (2012) estudaram metagranitos da porção sul do Orógeno Dabie, inseridos na zona do eclogito de ultra-alta pressão e baixa temperatura. Esta rocha contém granada também semelhante em composição com a granada presente no BMF e nos demais corpos referidos acima.

Neste estudo, duas amostras coletadas tiveram cristais de granada analisados, denominados G2 e G9 para a primeira amostra (01SS71) e G3-1 e G3-2 para a segunda amostra (01SS59). Em todos os casos analisados, Grs\%+Sps\%+Alm\% compõem aproximadamente 94\% da composição total da granada, com alguma variação. Nota-se um zoneamento químico marcante com leve redução de Sps\% do centro para a borda dos cristais, assim como uma forte redução de Grs\% no mesmo sentido (centro-borda); e uma pequena variação positiva no manto e também um aumento de Alm\% (centro-borda). As razões $\mathrm{Fe} / \mathrm{Mg}$ são sempre maiores no centro e menores na borda. Como exceção, o cristal analisado G3-1 apresenta um centro rico em Sps\% e relativamente pobre em Grs\%, com uma redução brusca de Sps\% para o manto, mantendo-se na borda, e aumento de Grs\% que se mantém no centro (Figura 21). Os cristais analisados para elementos terras-raras apresentam um aumento significativo de elementos terras-raras pesados no manto em comparação com o centro e a borda.

Para interpretar as condições de temperatura e pressão, os referidos autores se utilizam de dois parâmetros: Grs\% e razões Fe/Mg. A Grs\% apresenta uma tendência de aumento com o incremento da pressão na rocha, com algumas exceções, sendo a maior Grs\% na granada indicativa da maior pressão submetida à rocha. A razão $\mathrm{Fe} / \mathrm{Mg}$ é considerada um indicador de temperatura, 
sendo o seu aumento conforme o incremento da temperatura, indicando que a posição com maior razão Fe/Mg corresponderia ao pico de temperatura atingido pela rocha. De acordo com estes dois parâmetros (Grs\% e Fe/Mg), os autores dividem a granada em três gerações de formação, denominadas, respectivamente, Grt-I, Grt-II e Grt-III. A Grt-I corresponde ao centro do cristal G3-1, com valores constantemente baixos de Grs\% e de Fe/Mg, indicando que ele foi submetido a mais baixa pressão e mais alta temperatura. A Grt-II pode se apresentar como manto ou centro, dependendo do cristal analisado. Apresenta, inversamente, alto valor de Grs\% e baixa razão $\mathrm{Fe} / \mathrm{Mg}$, sugerindo uma geração de alta pressão e com temperaturas reduzidas. A Grt-III é referente à borda dos cristais, apresentando tanto baixo valor de Grs\% quanto baixa razão Fe/Mg.
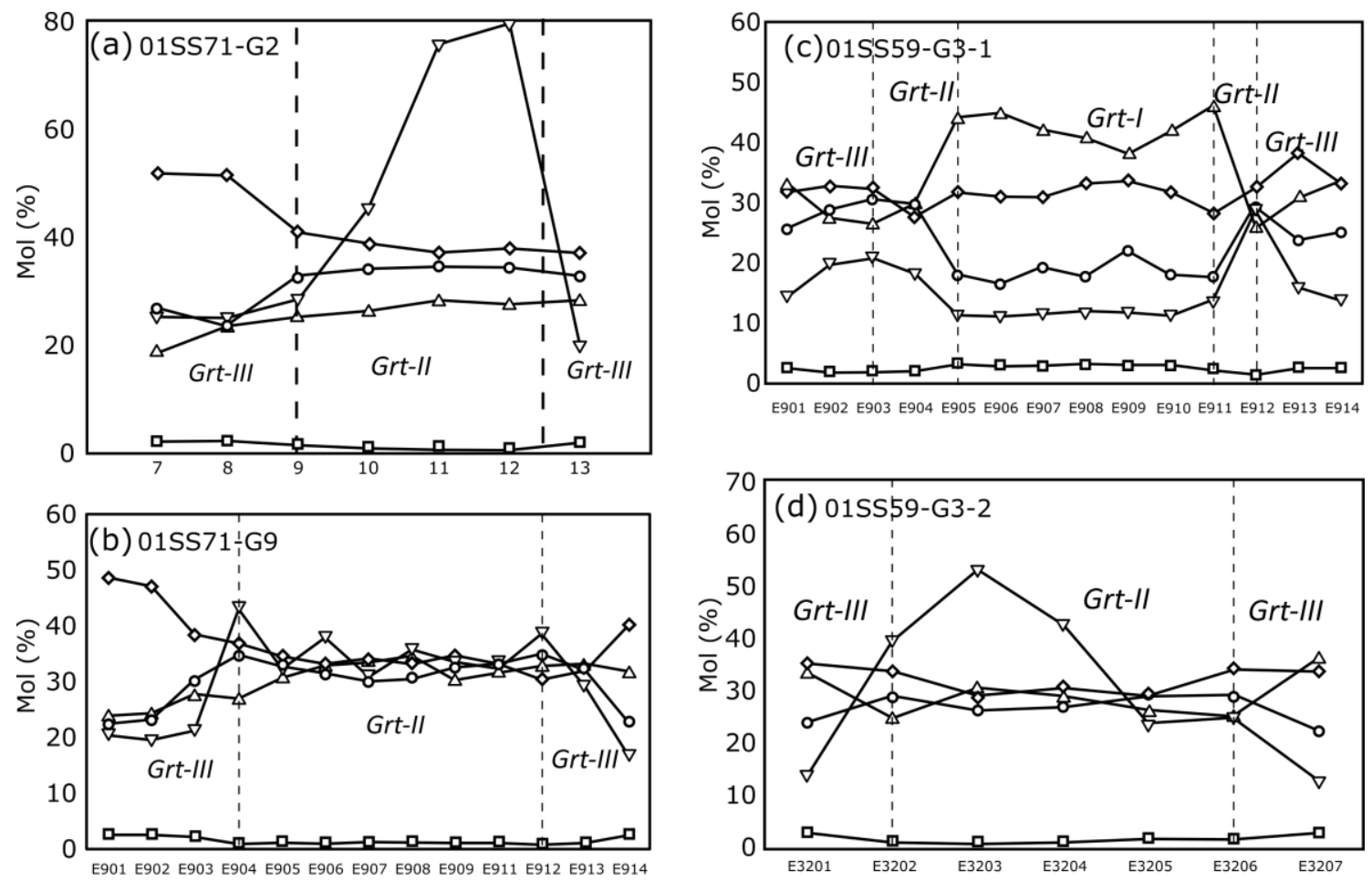

$\diamond$ Almandina

口 Piropo

Grossulária

$\Delta$ Espessartita $\nabla \mathrm{Fe} / \mathrm{Mg}$

Figura 21 - Perfis composicionais de granada em metagranitos do Orógeno Dabie-Sul, mostrando o padrão dos principais endmembers e a razão Fe/Mg. Retirado de Xia et al. (2012).

Com relação aos elementos terras-raras analisados, temos indicações da origem de cada uma das gerações de granada. A presença de anomalia negativa de Eu e alto conteúdo relativo de elementos terras-raras nos cristais de Grt-I, com relação às outras gerações de granada, sugerem uma origem magmática para os mesmos, em contraponto com uma origem metamórfica de fácies 
eclogito para os cristais Grt-II e Grt-III, cujas gerações não apresentam anomalia negativa de Eu proeminente, juntamente com baixo conteúdo relativo de elementos terras-raras. Essas rochas formaram sua primeira geração de granada em seu estágio de cristalização, sendo depois deformadas pela colisão continental que afetou a região. A Grt-II representa o estágio metamórfico durante a progressão da subducção e alcançou o pico de pressão ao atingir o valor máximo da Grs\%. A Grt-III representa então o sobrecrescimento devido à exumação do orógeno e está, portanto, relacionada com a descompressão do mesmo (Grs\% reduzidos) e aumento de temperatura (aumento da razão $\mathrm{Fe} / \mathrm{Mg}$ ).

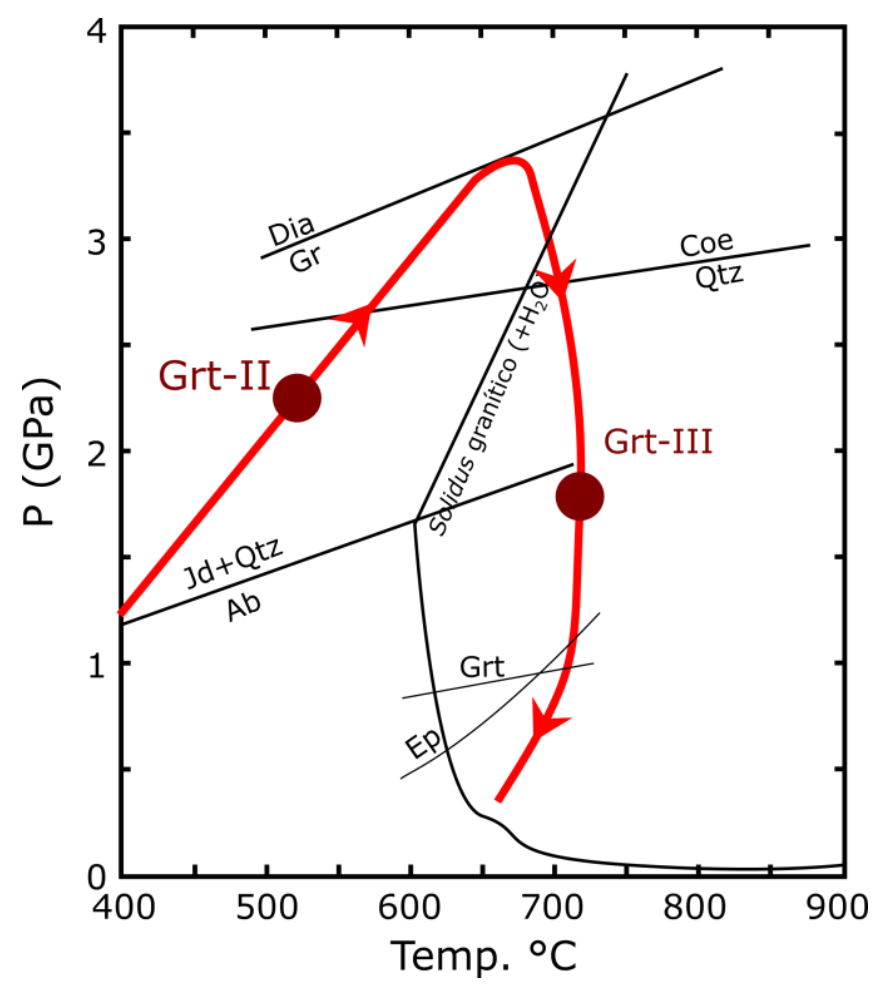

Figura 22 - O caminho P-T-t do crescimento dos cristais de granada dos metagranitos do Orógeno DabieSul durante a subducção. Retirado de Xia et al (2012).

Diante disso é possível confirmar a evolução de pressão e temperatura do metamorfismo no Orógeno Dabie-Sul, proposta por Li et al. (2004) e Zheng et al. (2011). A figura 22 apresenta essa evolução, posicionando as gerações de GrtII e Grt-III no caminho P-T-t do metamorfismo. Assim, a Grt-II representa a fase de subducção, que é acompanhada pelo aumento progressivo da pressão, enquanto a Grt-III representa a fase de exumação, ou seja, a fase que é acompanhada pela tendência de redução das pressões e por um leve aumento 
de temperatura, a qual pode ser explicada pelo desequilíbrio de fases hidratadas pela diminuição da pressão.

\subsubsection{Discussão}

Os resultados obtidos sobre a composição química de granada por Narduzzi et al (2017) Zen e Hammarstrom (1984) e Xia et al (2012) são muito semelhantes. Isso não seria um fato notório por si só se as composições estivessem dentro do esperado para granada em granitos ou metagranitos. Os autores se valem também de experimentos e composições naturais de granada disponíveis na literatura e demonstram que as granadas de corpos graníticos deveriam ser compostas principalmente de almandina e piropo, com baixos teores dos outros endmembers. Para avaliar essa afirmação foram organizados
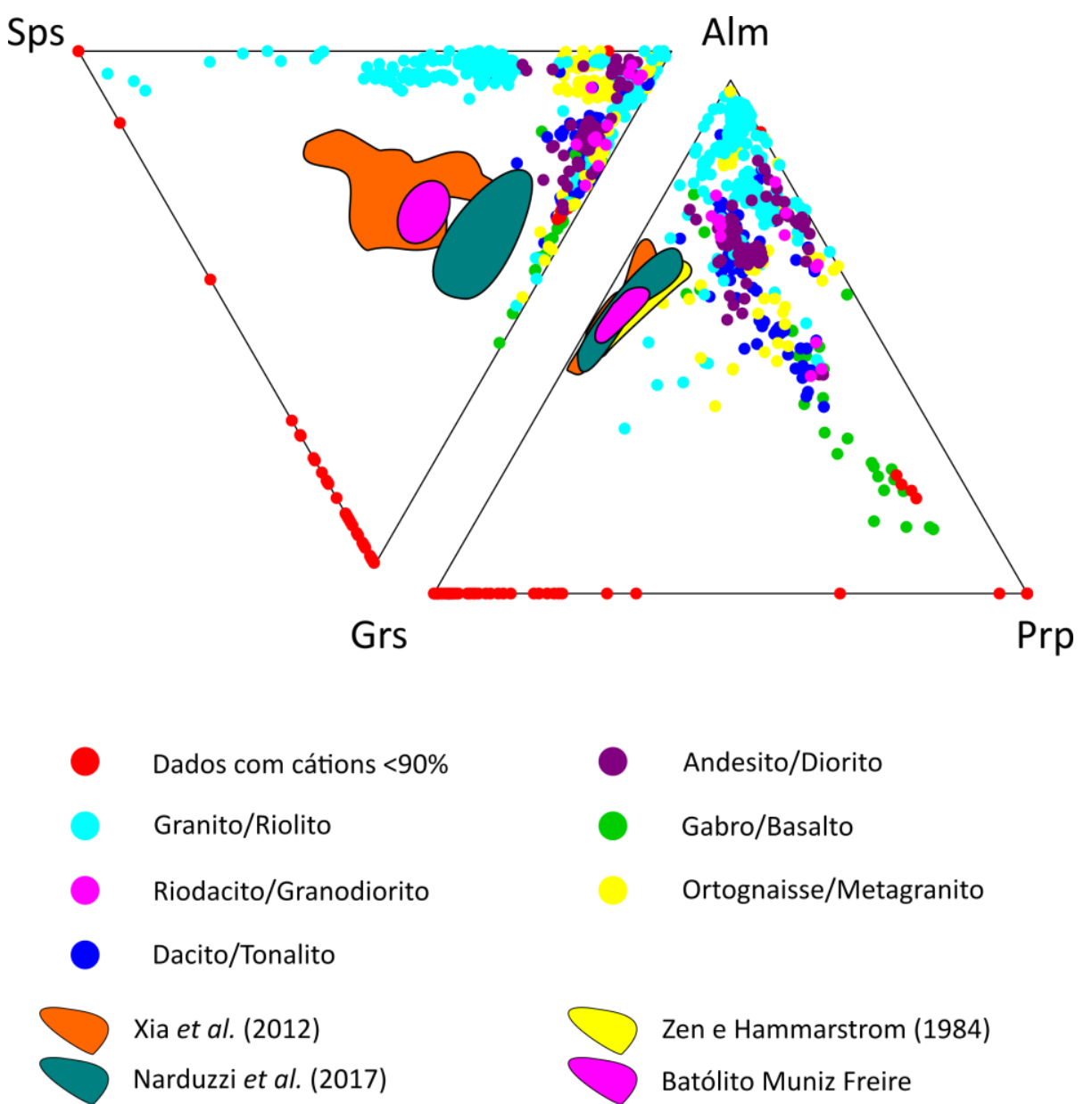

Figura 23 - Análises de granada dos bancos de dados GEOROC (Sarbas, 2008) e de Suggate e Hall (2014) separado nos principais endmembers para esse mineral. Os pontos foram separados em cores baseado no grau de diferenciação das rochas, com seus representantes plutônicos e vulcânicos. Pontos em vermelho correspondem a amostras que contém endmembers raros que não foram calculados. Os campos demarcados correspondem à composição de granada dos corpos usados como comparação neste trabalho. 
na figura 23 dados de análise de granada em rochas ígneas a partir de uma compilação de dados de granitoides e metagranitoides (Suggate e Hall, 2014) e de um banco de dados de análises em granada (o GEOROC, Sarbas, 2008).

Observa-se nessa figura (23) que a grande maioria das rochas ígneas varia entre Alm\% e Pir\% com a Grs\% sendo relativamente constante, raramente excedendo a 25\%. Na linha de variação entre Alm\% e Pir\% (1) nota-se uma progressão no grau de diferenciação dessas rochas, com as básicas sendo mais ricas em Pir\% e as ácidas mais ricas em Alm\%. Nota-se também que as rochas de mais alta temperatura de fusão apresentam conteúdos de Mg mais elevados e rochas de menor ponto de fusão são mais enriquecidas em Fe. Além disso, observa-se que são raras as amostras em que coexistem Grs\% >10\% e Sps\%>10\%. Quando consideradas apenas Grs\%, Alm\% e Sps\%, observam-se duas tendências: uma entre Sps\% e Alm\%(2), com diversas amostras sendo muito ricas em Sps\% (>50\%) e outra entre Alm\% e Grs\%, a qual é mais sensível aos baixos valores em espessartita, já que qualquer amostra que apresente altos valores da razão $\mathrm{Fe} / \mathrm{Mg}$ e com pouca quantidade de Sps\% sobrará proporcionalmente muita grossulária, logo, essa concentração na realidade é apenas a variação entre Alm\% e Pir\% novamente.

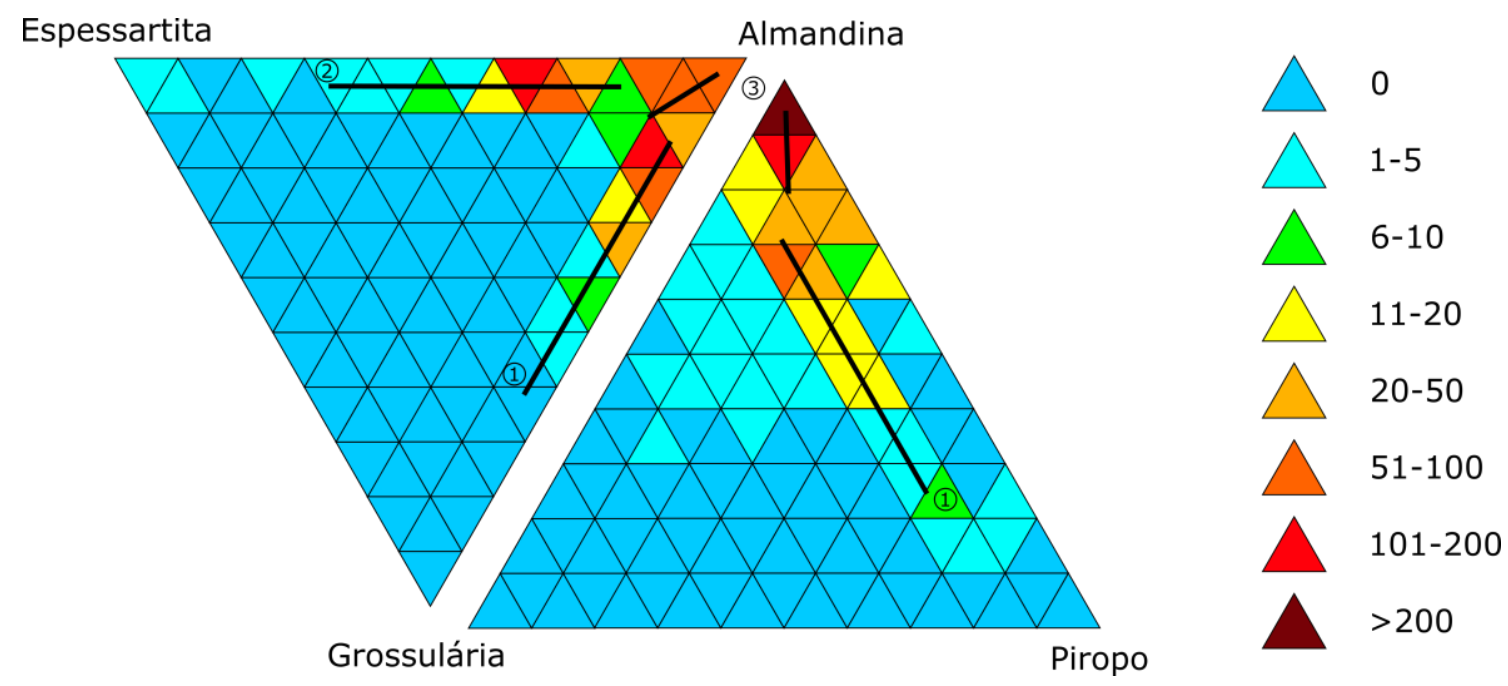

Figura 24 - Gráficos ternários de composição de granada expondo densidade de pontos realizado a partir do gráfico da figura 23. As linhas correspondem às principais tendências de composição de granada para essas rochas. 
A partir dessas observações, conclui-se que granada de corpos ígneos ou metaígneos deveriam ser compostas principalmente de Alm\%+Pir\%, compondo pelo menos $75 \%$ de sua composição com Grs\% e no máximo $25 \%$ (1); de Alm\%+Sps\% com Pir\% $<10 \%$ e/ou Grs $<10 \%$ (2), e/ou como ocorre na maioria dos casos, com a Alm\% compondo $70 \%$ ou mais da granada e os demais componentes raramente sendo superiores a $20 \%$ (3). No caso das granadas do BMF, do Batólito Galiléia, do Tonalito de Bushy Point e dos metagranitos de Dabie-Sul, elas não se encaixam em nenhum dos três tipos descritos acima, sendo tais granadas constituídas de Alm\%+Sps\%+Grs\% em proporções semelhantes, com Pir $<5 \%$ (Figura 24).

Os autores acima explicam essas composições utilizando-se de diversas metodologias. Duas delas são especialmente recorrentes nos artigos: 1- O Pir\% é proporcional a temperatura de formação da rocha; 2- A Grs\% é proporcional a pressão de formação da rocha. A partir dessas constatações, os autores desenvolveram modelos para explicar a história termobarométrica dos corpos estudados. Um deles é que a Grs\% tem valores recorrentemente acima do esperado, sendo possível assumir que essas rochas, incluindo as do BMF, foram intrudidas sob condições de altas pressões e possivelmente foram sujeitas a esforços tectônicos ou espessamento crustal que elevaram sua pressão, promovendo uma variação de forma da Grs\%, de modo a ocorrer seu equilíbrio nas novas condições báricas. Ressalte-se que todo esse processo se deu em temperaturas baixas, já que com Pir\% de todos os cristais dos corpos analisados raramente é superior a $5 \%$.

Para a cristalização da granada do Tonalito de Bushy Point são propostas pressões mínimas de 13-15 kbar (Zen e Hammarstrom (1984). Como referência, utilizaram-se dos experimentos de Green (1992) que indicam a cristalização de granada no limite mínimo de temperatura $\sim 900^{\circ} \mathrm{C}$, condição essa de pressão correspondente a dos andesitos hidratados $\left(+10 \% \mathrm{H}_{2} \mathrm{O}\right)$. Narduzzi et al. (2017) estimam, com base nos altos teores de grossulária e na presença de epídoto magmático, uma pressão mínima de $8 \mathrm{Kbar}$. Xia et al. (2012), com o objetivo de determinar a pressão atingida nos metagranitos de Dabie-Sul, valeram-se das informações metamórficas das rochas encaixantes e determinaram a pressão atingida nos eclogitos durante o evento colisional Triássico. Li et al. (2004) 
determinaram para o pico do metamorfismo desses eclogitos, com base na presença de pseudomorfos de coesita, uma temperatura ao redor de $670^{\circ} \mathrm{C} \mathrm{e}$ pressão de $33 \mathrm{Kbar}$. Estes dados mostram uma forte discrepância entre os valores apresentados, com uma pressão mínima de $8 \mathrm{Kbar}$ e máxima de $33 \mathrm{Kbar}$. Possivelmente, os granitoides citados tenham se colocado sob condições de altas pressões e em alguns casos foram metamorfizados em condições de ultraalta pressões, porém as análises para avaliar essa afirmação são escassas.

Contudo, há outra semelhança entre esses granitoides que merece ser destacada, que é a presença de epídoto primário no Batólito Galiléia (Nalini 1997, Nalini et al. 2005 e Narduzzi et al. 2017), assim como no Tonalito de Bushy Point (Zen e Hammarstrom 1984), com estes últimos autores sendo importantes na descoberta e estudo da existência de epídoto magmático. Ressalte-se que Xia et al. (2008) não identificam a presença de epídoto magmático, porém uma das fotomicrografias apresentadas pelos autores mostra a presença inequívoca de epídoto com um núcleo de allanita, uma das características distintivas de um epídoto magmático. Porém, estudos mais aprofundados fazem-se necessários para encontrar outras dessas características e confirmar a origem desse epídoto.

É possível explicar a presença de granadas incomuns em corpos ígneos pela simples possibilidade desses cristais não pertencerem a essas rochas, sendo xenocristais. Essa possibilidade, porém, se sustentaria apenas por uma série de coincidências, já que quatro corpos plutônicos de diferentes localidades geográficas, origens e idades, mostram semelhanças em sua evolução (altas pressões, presença de epídoto magmático, etc.) e apresentam granada com composição virtualmente idêntica. Para que fossem xenocristais, as rochas encaixantes dos quatro corpos teriam que ser semelhantes, o que é plausível para o BMF e o Batólito Galiléia, mas exigiriam coincidências com relação aos corpos da China e do Alaska. Estudos sobre as encaixantes se fazem necessários para compreender melhor essa questão. 


\subsubsection{Epídoto}

\subsubsection{Epídoto no Batólito Muniz Freire}

Perfis centro-borda foram realizados em sete cristais de epídoto contendo ou não núcleos de allanita (figuras 25 e 26), os quais possuíam pouco ou nenhum zoneamento. As análises de química mineral estão na tabela 4 e incluem apenas as análises mais significativas.

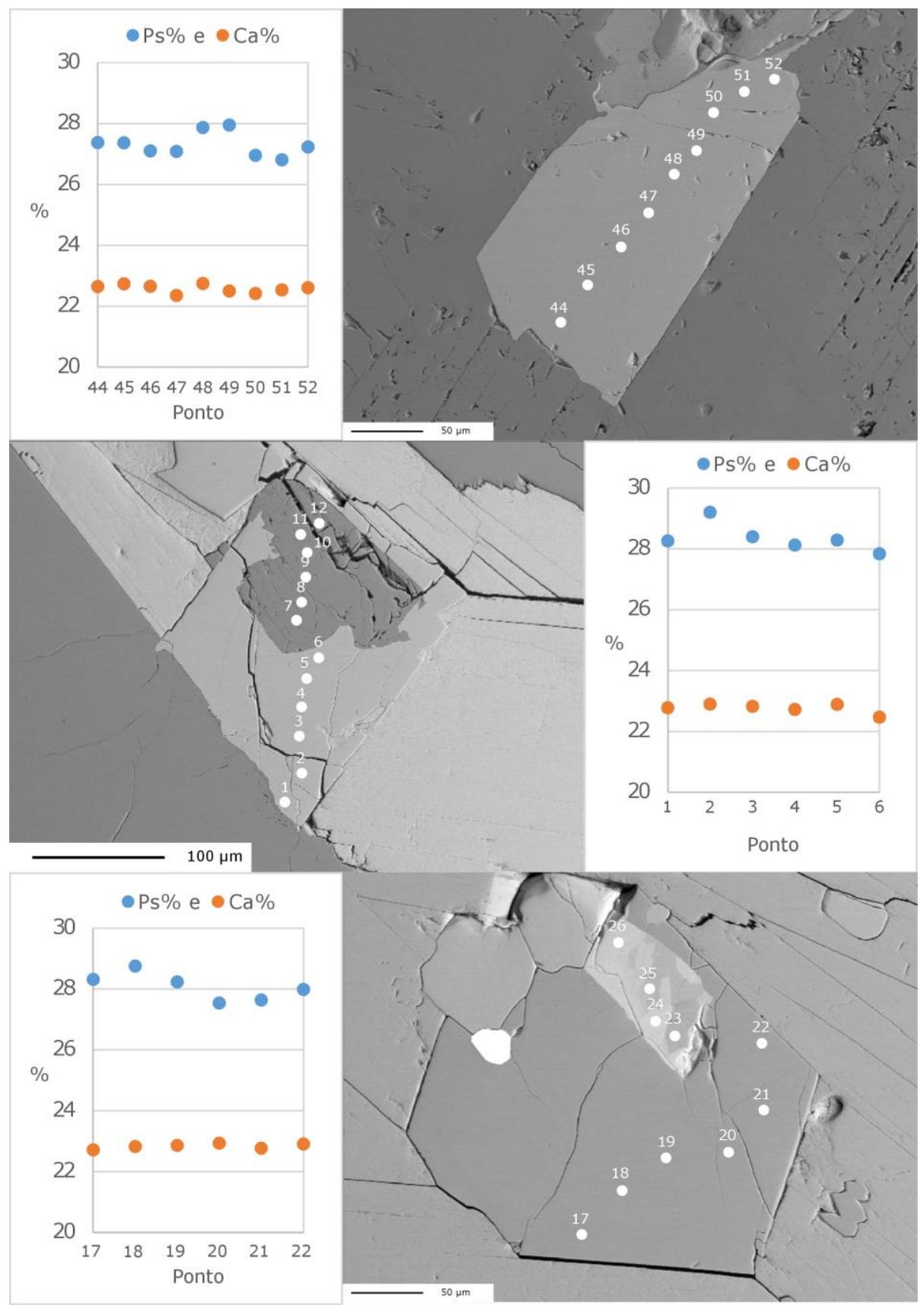

Figura 25 - Fotomicrografias e gráficos composicionais de perfis de análise de epídoto. Os números se referem aos pontos analisados. Pontos analisados que não correspondem a epídotoss não foram representados no gráfico. Os parâmetros Ps\% e Ca\% foram utilizados por serem as substituições mais importantes. 


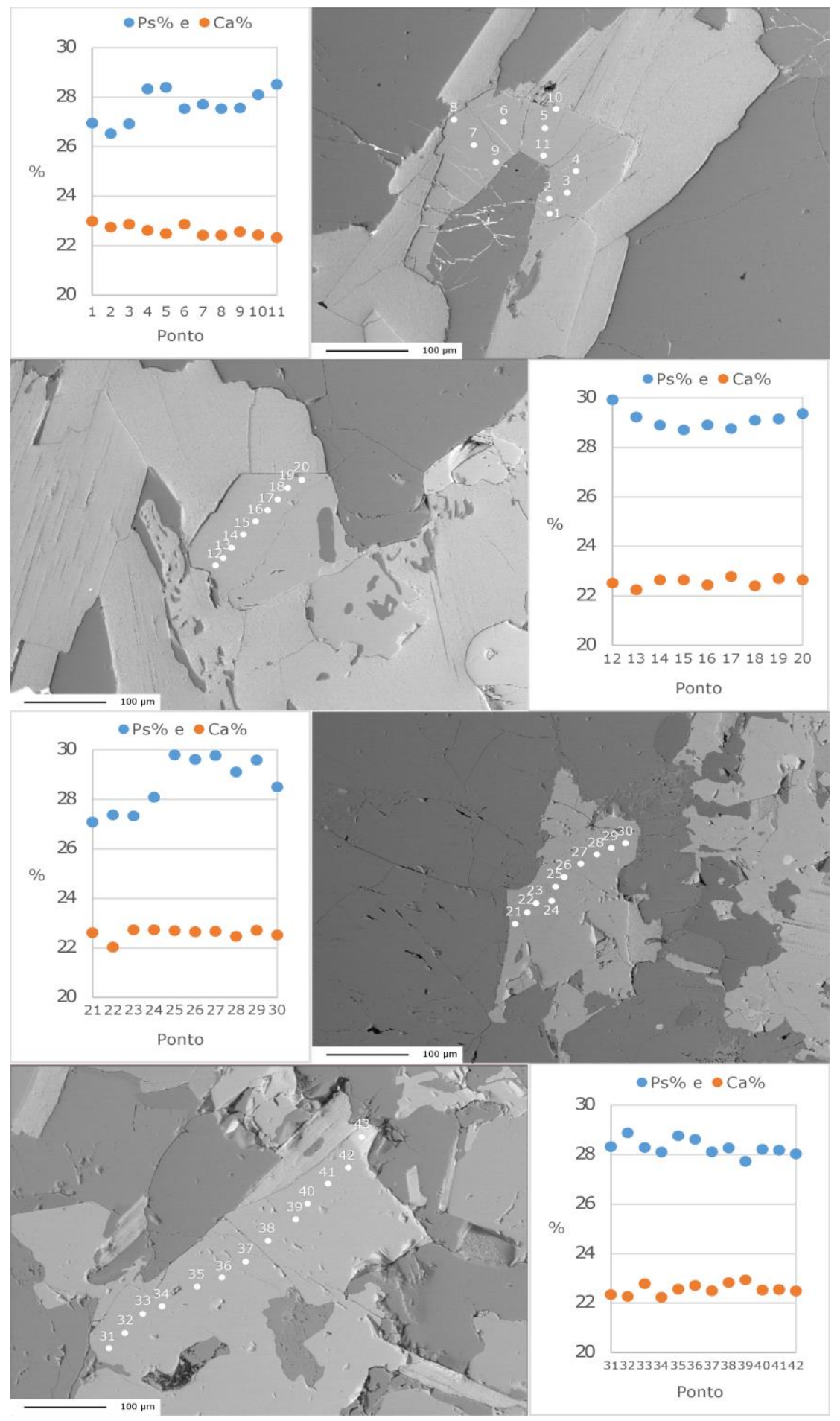

Figura 26 - Fotomicrografias e gráficos composicionais de perfis de análise de epídoto. Os números se referem aos pontos analisados. Pontos analisados que não correspondem a epídotoss não foram representados no gráfico. 


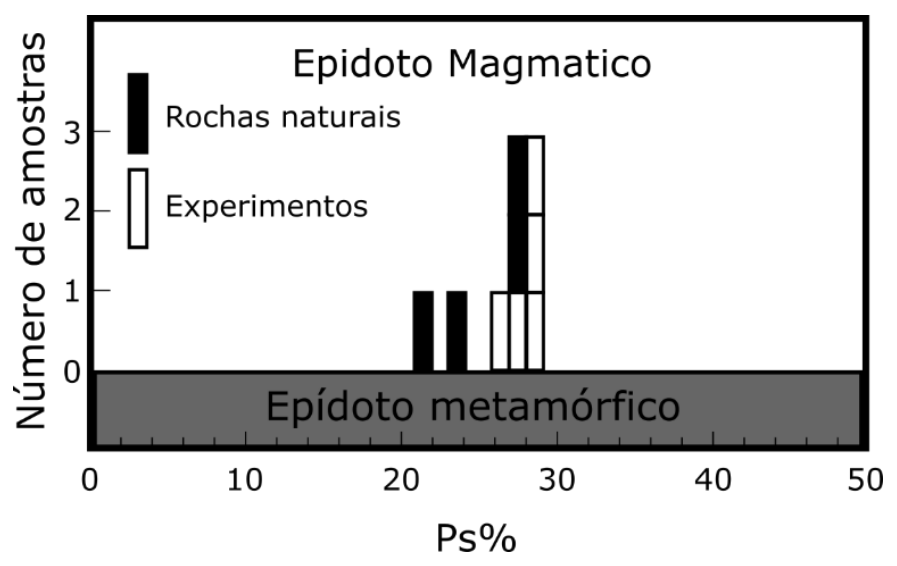

Figura 27 - Histograma mostrando composições em termos de Ps\% de epídoto magmático de rochas naturais e experimentos. Retirado de Johnston e Wyllie (1988).

Os perfis foram representados em gráficos usando o contéudo de pistacita (Ps\%) $(\mathrm{Fe} / \mathrm{Fe}+\mathrm{Al})$ e $\mathrm{Ca}$ por representarem as substituições mais importantes neste mineral (Ps\% representa substituição de $\mathrm{Al}$ por $\mathrm{Fe}^{3+}$ e Ca\% representa a substituição de $\mathrm{Ca}$ por ETR como $\mathrm{Ce}$, La, etc.). Vale lembrar que pistacita correspondia à composição hipotética $\mathrm{Ca}_{2} \mathrm{Fe}_{3}{ }^{+3}\left[\mathrm{Si}_{2} \mathrm{O}_{7}\right]\left[\mathrm{SiO}_{4}\right] \mathrm{O}(\mathrm{OH})$, porém esse nome não é reconhecido pela IMA (International Mineralogists Association) e será usado aqui apenas como convenção para se referir à razão $\mathrm{Fe} / \mathrm{Fe}+\mathrm{Al}$.

O conteúdo de pistacita (Ps\%) desses cristais varia de $26-30 \%$ (tabela 4), valor compatível com os experimentos realizados por Naney (1983), mas que carece de significado relevante como demonstrado por Schmidt e Poli (2004), já que a Ps\% do epídoto não é uma propriedade diagnóstica de sua origem como acreditavam os autores anteriormente. Isso pode ser observado de forma detalhada na figura 27, que mostra o conteúdo de Ps\% de rochas naturais, experimentos e dados de cristais gerados por metamorfismo, mostrando que 0 intervalo de $20-30 \%$ de Ps\% pode ser referente tanto para cristais primários quando para cristais secundários.

Petrograficamente, a maior parte das fases acessórias ocorre como agregados em contato com a biotita, provavelmente devido ao fato de compartilharem uma cristalização precoce que, durante a ascensão do magma, esses cristais permanecerem juntos no fundido. Essa característica é especialmente marcante nos cristais de epídoto. Esses cristais, não só ocorrem em contato com a biotita, como também quando não estão em contato com ela, 
apresentam bordas irregulares, com texturas de reabsorção. Essas texturas não ocorrem, porém, em cristais de epídoto de algumas amostras de composição tonalítica (Figura 29B). Isso sugere que o epídoto seria metaestável em certas condições P-T e composições mais diferenciadas (granodiorítica a granítica) e precisaria estar manteado por cristais de biotita para sobreviver e não ser reabsorvido pelo fundido quartzo-feldspático. O epídoto pode apresentar núcleos de allanita e, quando em contato com a matriz quartzo-feldspática, apresenta limite corroído, podendo ser absorvido até seu núcleo allanítico, salvo exceções. (Figura 28, 29A)

Schmidt e Thompsom (1996) e Schmidt e Poli (2004) elencaram diversas características petrográficas que serviriam de evidências para diferenciar 0 epídoto primário de epídoto metamórfico ou de alteração, a saber: 1 - Evidências confiáveis de zoneamento, com núcleos allaníticos, embora a falta desse zoneamento não exclua uma origem primária; 2 - Considera-se tipicamente magmática a textura do tipo ofítica; 3 - Texturas de reação quando em contato com a matriz quartzo-feldspática sugerem que o epídoto pode não estar ocorrendo de forma estável nos estágios finais da cristalização; 4 - Epídoto magmático pode ocorrer na matriz quartzo-feldspática como cristais isolados e euhedrais, com textura gráfica, o que é evidência de uma origem primária; 5 - A ausência de alteração na biotita e plagioclásio pouco alterado exclui a possibilidade de um retrometarmorfismo ou hidrotermalismo, sugerindo que 0 epídoto não faz parte de uma fase subsolidus.

De acordo com esses critérios (principalmente os critérios 1, 3 e 5) e, como descrito acima, é provável que o epídoto do BMF seja de origem primária. $\mathrm{O}$ gráfico desenvolvido por Schmidt e Poli (2004) demonstra os campos de estabilidade do epídoto em condições P-T para várias composições e modelos teóricos (figura 30). O epídoto é estável em um campo maior de P-T para composições tonalíticas e é bem reduzido para composições graníticas, o que é condizente com as interpretações petrográficas, onde o epídoto pode ser metaestável em composições mais diferenciadas (granodioríticas) e estável em composições menos diferenciadas (tonalíticas com hornblenda - amostra STX 279A). 


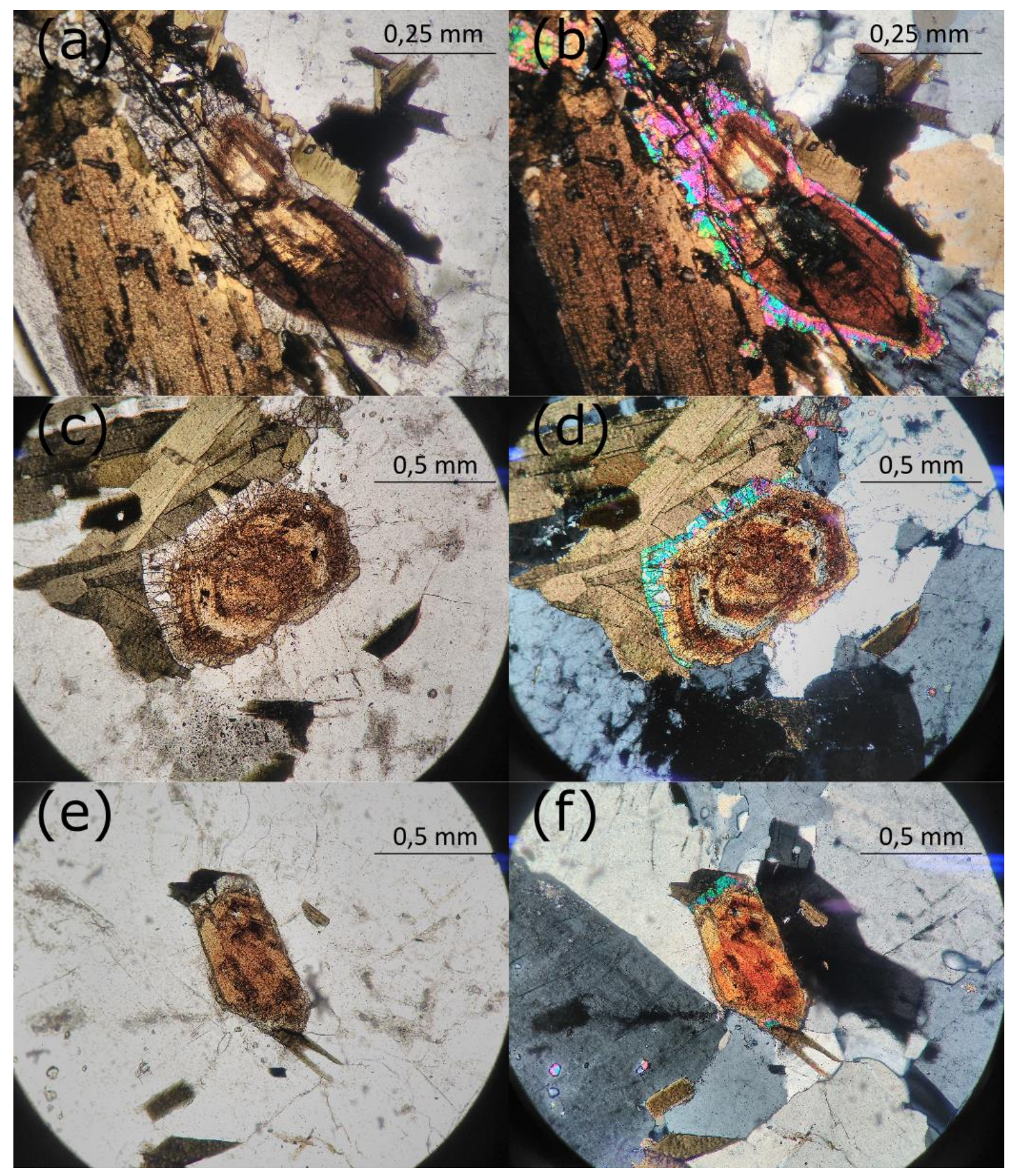

Figura 28 - Fotomicrografias de cristais de allanita com borda de epídotoss. Note que para essas amostras, epídotoss apenas manteia allanita quando em contato com biotita. Isso só não é válido para a (a) e (b), onde epídoto se preserva em contato com a matriz quartzo feldspática, porém apresenta bordas corroídas. (a), (c) e (e) foram obtidas com nicóis paralelos, enquanto (b), (d) e (f) são, respectivamente, suas contrapartes com nicóis cruzados. (a) e (b) - Amostra STX-278. (c), (d), (e) e (f) - Amostra STX-282. 
Tabela 5

Análises quantitativas obtidas por WDS de elementos maiores e traços em epídoto do Batólito Muniz Freire.

\begin{tabular}{|c|c|c|c|c|c|c|c|c|c|c|c|c|c|c|c|}
\hline \multirow{2}{*}{$\begin{array}{l}\text { Cristal } \\
\text { Local }\end{array}$} & \multirow{2}{*}{$\frac{\text { PMF14A-1 }}{\text { Centro }}$} & \multirow{2}{*}{ Borda } & \multicolumn{2}{|c|}{ PMF14A-2 } & \multirow{2}{*}{$\begin{array}{l}\text { PMF14A-3 } \\
\text { Centro }\end{array}$} & \multirow{2}{*}{ Borda } & \multicolumn{2}{|c|}{ PMF14A-4 } & \multicolumn{2}{|l|}{ PMF14A-5 } & \multicolumn{2}{|l|}{ STX282-1 } & \multirow{2}{*}{$\begin{array}{l}\text { STX282-2 } \\
\text { Centro }\end{array}$} & \multirow{2}{*}{$\begin{array}{l}\text { STX282-3 } \\
\text { Centro }\end{array}$} & \multirow[b]{2}{*}{ Borda } \\
\hline & & & Centro & Borda & & & Centro & Borda & Centro & Borda & Centro & Borda & & & \\
\hline Si & 37,82 & 37,47 & 37,63 & 37,24 & 37,37 & 37,48 & 37,36 & 37,41 & 37,46 & 37,46 & 37,57 & 37,77 & 37,65 & 37,75 & 37,81 \\
\hline$Y$ & 0,00 & 0,00 & 0,02 & 0,00 & 0,00 & 0,04 & 0,00 & 0,00 & 0,00 & 0,00 & 0,00 & 0,00 & 0,00 & 0,00 & 0,00 \\
\hline $\mathrm{Fe}$ & 13,85 & 13,85 & 14,43 & 14,57 & 14,82 & 13,6 & 14,26 & 14,11 & 13,61 & 13,62 & 14,17 & 14,30 & 14,13 & 14,27 & 14,20 \\
\hline $\mathrm{Mn}$ & 0,31 & 0,38 & 0,56 & 0,49 & 0,40 & 0,34 & 0,35 & 0,36 & 0,28 & 0,34 & 0,28 & 0,32 & 0,28 & 0,35 & 0,33 \\
\hline $\mathrm{Ca}$ & 22,43 & 22,43 & 22,45 & 22,65 & 22,65 & 22,61 & 22,83 & 22,34 & 22,35 & 22,61 & 22,73 & 22,78 & 22,63 & 22,86 & 22,91 \\
\hline Th & 0,12 & 0,00 & 0,00 & 0,00 & 0,00 & 0,17 & 0,00 & 0,29 & 0,02 & 0,04 & 0,00 & 0,00 & 0,00 & 0,07 & 0,03 \\
\hline $\mathrm{Ti}$ & 0,15 & 0,07 & 0,10 & 0,16 & 0,02 & 0,06 & 0,06 & 0,11 & 0,14 & 0,12 & 0,07 & 0,03 & 0,06 & 0,09 & 0,10 \\
\hline La & 0,06 & 0,00 & 0,01 & 0,02 & 0,00 & 0,00 & 0,02 & 0,01 & 0,02 & 0,06 & 0,03 & 0,00 & 0,03 & 0,00 & 0,01 \\
\hline $\mathrm{Ce}$ & 0,00 & 0,00 & 0,00 & 0,06 & 0,00 & 0,00 & 0,00 & 0,00 & 0,046 & 0,00 & 0,04 & 0,00 & 0,01 & 0,00 & 0,00 \\
\hline $\mathrm{Al}$ & 23,06 & 23,27 & 22,65 & 22,37 & 22,49 & 23,38 & 23,11 & 22,80 & 23,39 & 23,24 & 23,12 & 23,17 & 23,14 & 23,16 & 23,33 \\
\hline $\mathrm{Mg}$ & 0,00 & 0,04 & 0,012 & 0,02 & 0,01 & 0,01 & 0,02 & 0,01 & 0,00 & 0,00 & 0,01 & 0,014 & 0,05 & 0,03 & 0,05 \\
\hline Total & 97,80 & 97,51 & & & 97,76 & 97,70 & 98,02 & 97,45 & 97,32 & 97,50 & 98,03 & 98,39 & 97,97 & 98,58 & 98,77 \\
\hline Ps & 27,72 & 27,54 & 28,92 & 29,37 & 29,61 & 27,08 & 28,26 & 28,32 & 27,09 & 27,23 & 28,13 & 28,27 & 28,05 & 28,23 & 27,99 \\
\hline
\end{tabular}




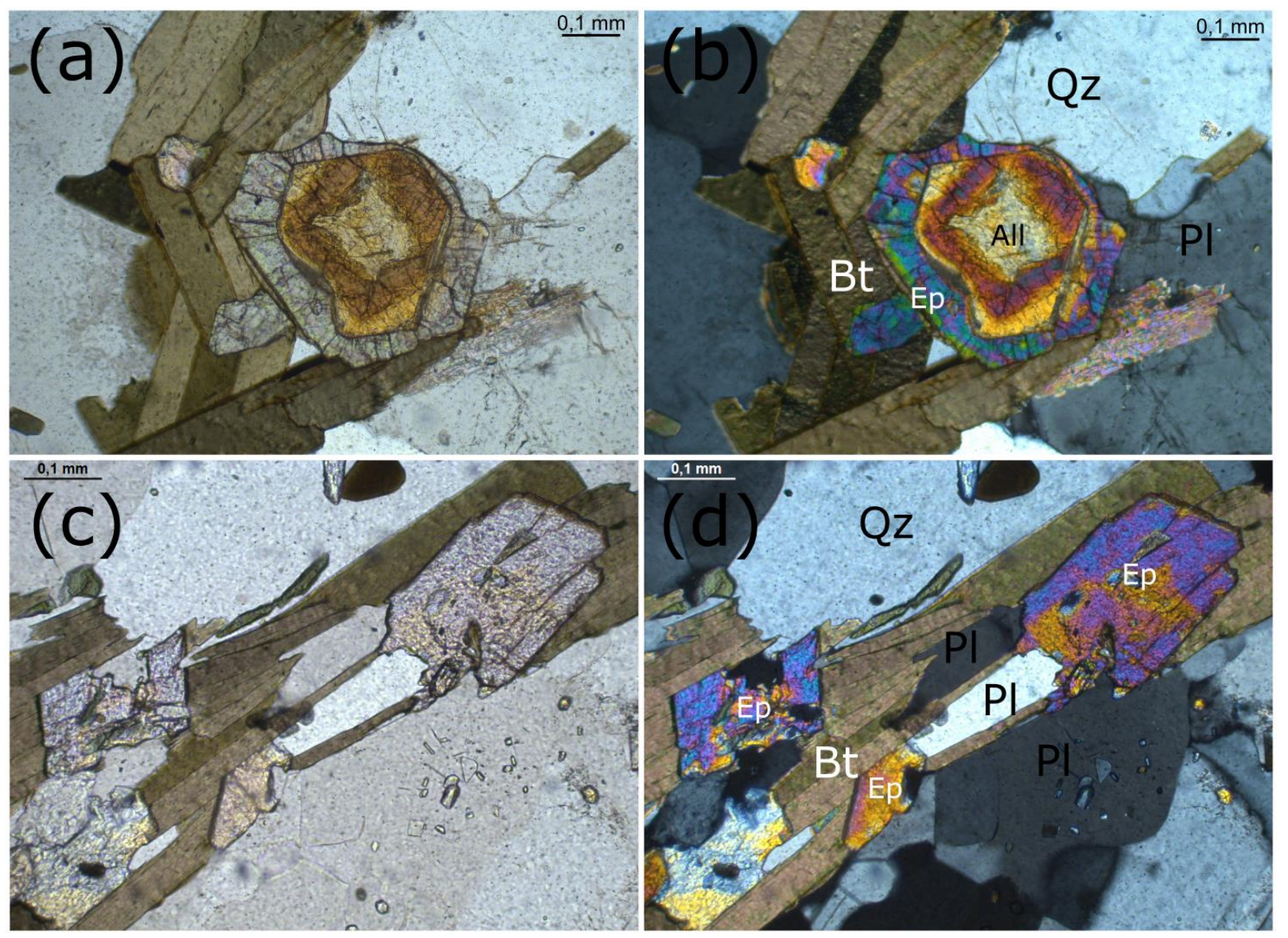

Figura 29 - Fotomicrografias de amostras com epidotoss. (a) e (b) mostram epídoto com núcleo allanítico na amostra STX-278. Epídoto está preservado, com contatos retilíneos, quando em contato com biotita, porém apresenta borda parcialmente corroída quando em contato com plagioclásio e quartzo. É interessante notar nessa amostra a reação (1) da sessão 8.5.3.2 acontecendo na borda do cristal. (c) e (d) mostram cristais de epídoto em contato com biotita e com a matriz quartzo feldspática na amostra STX-279A. Os cristais apresentam pouca ou nenhuma corrosão, por vezes preservando os contatos retilíneos quando em contato com a matriz, o que não ocorre nas outras amostras. As fotos (a) e (c) foram obtidas com nicóis paralelos, enquanto (b) e (d) foram obtidas com nicóis cruzados. 


\subsubsection{Discussão}

Schmidt e Thompsom (1996) demonstraram que o campo de estabilidade do epídoto é fortemente dependente do grau de oxidação do magma. No caso de um tonalito natural, o intercepto das condições de cristalização do epídoto e do solidus para tonalitos hidratados seria normalmente de $5 \mathrm{~Kb}$ (em condições de $\mathrm{fO}_{2}$ de Ni$\mathrm{Ni}-\mathrm{O}$ ), quando em condições mais oxidantes (no caso, hematita-magnetita), cairia para $3 \mathrm{~Kb}$, aumentando significativamente o campo de estabilidade do epídoto e possibilitando sua presença em pressões mais baixas. Assumindo condições Ni$\mathrm{Ni}-\mathrm{O}$ para o BMF, pode-se utilizar o gráfico da figura 30 para estabelecer as condições P-T em que o epídoto seria estável para tonalitos e metaestável para granodioritos.

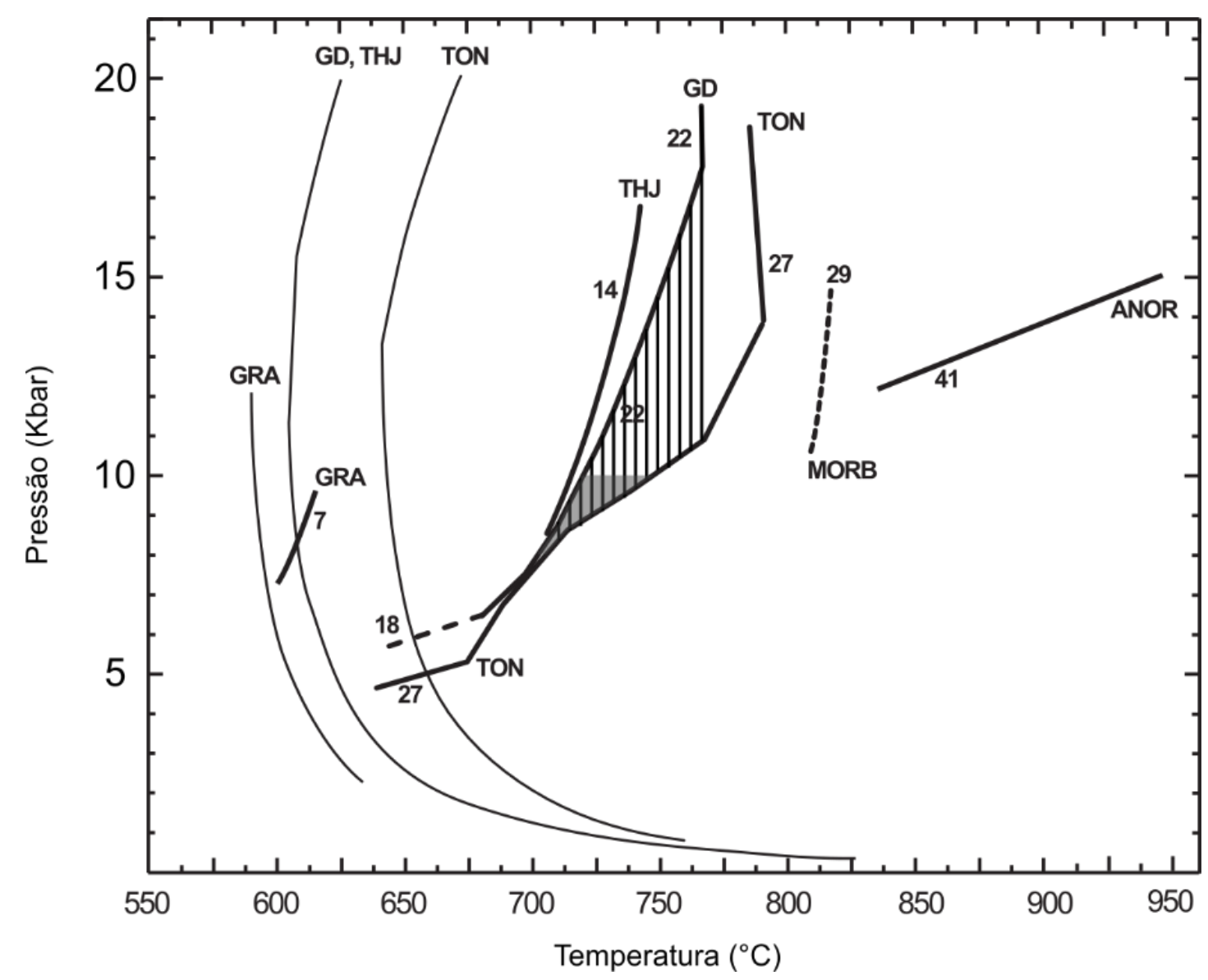

Figura 30 - Solidi (linhas finas) e reações delimitantes dos campos de estabilidade de epídoto magmático (linhas grossas) para diferentes magmas a condições de saturação de $\mathrm{H}_{2} \mathrm{O}$ (exceto para MORB). GRA = Granito, GD = Granodiorito, THJ = Throndjemito, TON = Tonalito, ANOR = Anortosito, MORB = Basaltos de dorsal meso-oceânica. Números se referem a An\% normativa (CIPW) de plagioclásio. Área hachurada é referente ao campo de estabilidade de epídoto estimado para rochas do BMF sem limite de pressão, enquanto o campo cinza é para pressões de 8 a 10 Kbar. Modificado de Schmidt e Poli (2004). 
Considerando que o epídoto tenha se cristalizado em condições P-T dentro do seu campo de estabilidade para composições tonalíticas a granodioríticas e tornou-se metaestável devido à ascensão do magma para pressões crustais menores, pode-se interpretar que o epídoto iniciou sua cristalização a no máximo $770^{\circ} \mathrm{C}$ (área hachurada no gráfico). Porém, esse limite ocorreria apenas a altas pressões, aproximadamente $19 \mathrm{Kbar}$. Além disso, o magma limitaria-se a ascender até pressões de $11 \mathrm{Kbar}$, onde, para essas condições de temperatura, o epídoto deixa de ser estável em composições tonalíticas.

Para certificar-se da pressão de cristalização do BMF, alguns métodos de geotermobarometria foram utilizados, a exemplo do método geobarométrico desenvolvido por Schmidt e Poli (2004). Os autores desenvolveram um método a partir da ordem de cristalização de epídoto para rochas oxidadas em NNO e de composição granodioríticas, com os seguintes intervalos de pressão e associações de minerais correspondentes:

Acima de 10 Kbar: hornblenda > epídoto $>$ plagioclásio > biotita > quartzo > feldspato alcalino;

10 a 8 Kbar: hornblenda > plagioclásio > epídoto > biotita > quartzo > feldspato alcalino;

8 to 6 Kbar: hornblenda > plagioclásio > biotita > epídoto > quartzo > feldspato alcalino;

6 to 5 Kbar: hornblenda > plagioclásio $>$ biotita $>$ quartzo $>$ epídoto $>$ feldspato alcalino.

O epídoto, como pode ser observado nas fotomicrografias (figuras 28 e 29), se cristalizou antes da biotita. Porém, sua relação em granodioritos com plagioclásio é incerta, pois quando em contato com este mineral suas bordas mostram evidências de reabsorção. Isso limita a cristalização de epídoto no BMF a duas possibilidades: de 10 a 8 Kbar e acima de 10 Kbar. Para pressões de 10$8 \mathrm{Kbar}$, o epídoto seria metaestável em granodioritos e estável em tonalitos na área cinza da figura 30 . 


\subsubsection{Plagioclásio}

\subsubsection{Plagioclásio no Batólito Muniz Freire}

Foram realizados perfis de análises em plagioclásio de três amostras (STX265B, 20 pontos; STX-267, 14 pontos; STX-282, 20 pontos). Para a escolha dos cristais analisados, foram selecionados aqueles a partir de evidências petrográficas que diferenciassem diferentes tipos de plagioclásio. Um deles pertence a uma geração provavelmente mais precoce, uma vez que se tratam de cristais maiores e, portanto, foram os primeiros a se cristalizar a partir do líquido mais enriquecido em Ca. Esses cristais são referidos como PI-I (cristais maiores, mais bem formados, geralmente com geminação de acordo com a Lei da Albita, e são pouco alterados e a outra geração, representada por cristais pertencentes à matriz, sugerindo tratar-se de cristais mais tardios (são menores, de tamanho

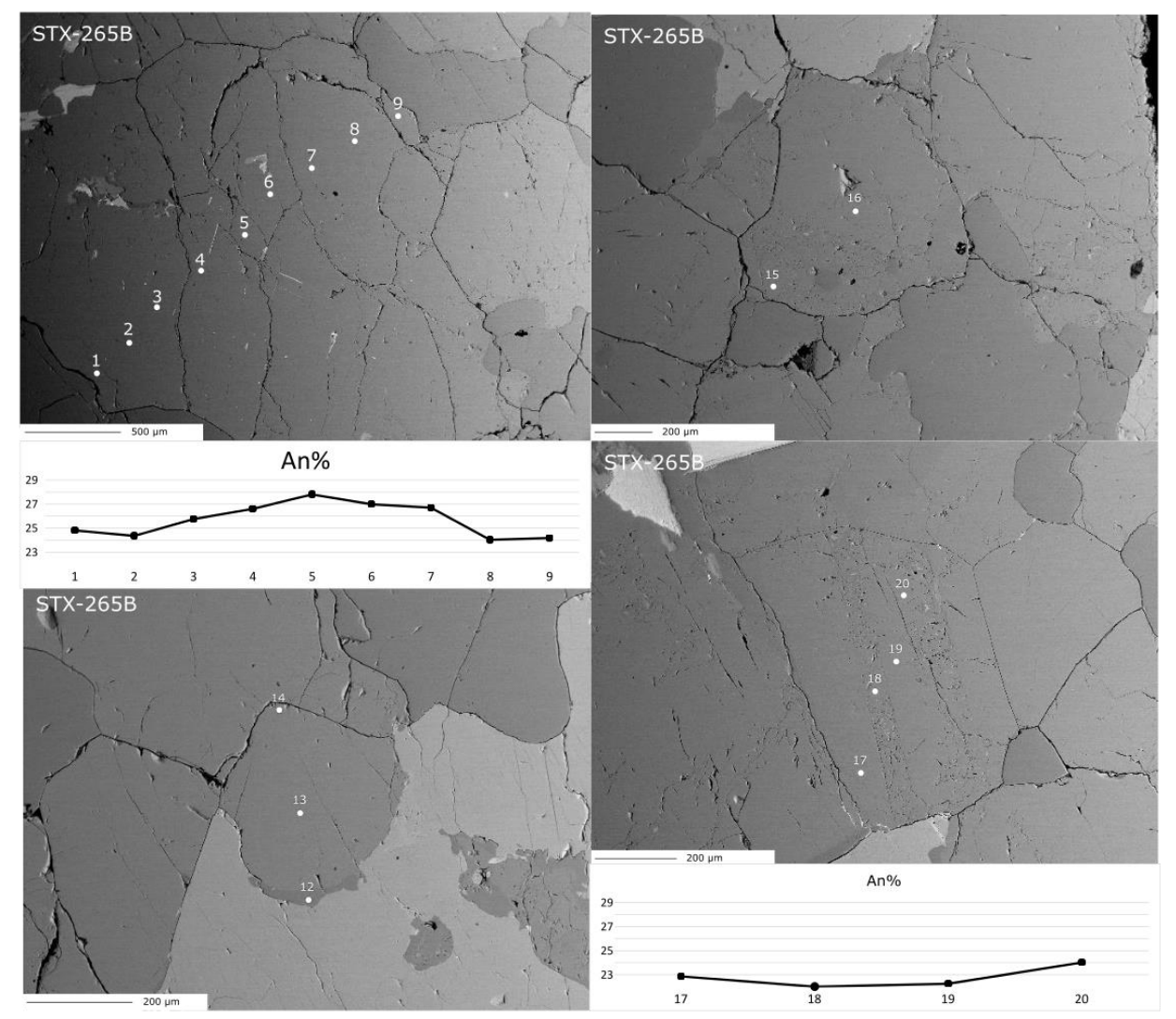

Figura 31 - Fotomicrografias e gráficos composicionais de perfis de análise de plagioclásio. Os números se referem aos pontos analisados. Cristais que tiveram apenas duas análises não tiveram seus perfis representados. Todas as imagens pertencem à amostra STX-265B.

regular e compatível com a granulação da matriz, sendo geralmente subidiomórficos a xenomórficos, não geminados e apenas com extinção zonada), 
sendo referidos como PI-II. Dessa forma, busca-se determinar se os cristais pertencem ou não a duas gerações distintas, sejam elas magmáticas ou metamórficas, apresentando comportamento químico semelhante ou distinto, com ênfase no teor de anortita (An\%).

Para tanto, foram feitos perfis de borda-centro-borda, bem como análises com um ponto no centro e outro na borda dos cristais de forma a ter parâmetros de seu zoneamento químico. Os resultados mais relevantes estão expostos nas tabelas 6 e 7 e as posições dos pontos dos perfis analíticos estão nas figuras 31 , 32 e 33 .

Pode-se observar que há dois comportamentos distintos nos teores de An\%. Os cristais de $\mathrm{PII}$ apresentam perfis de An\% em forma de sino, variando de An 27,8\%-24,2\%, para a amostra STX-265B, e de An\% 28,5\%-24,5\% e An\% 31,2\%$20,6 \%$, para a amostra STX - 267, com todos os valores tendo sido obtidos do centro para a borda dos cristais. Os cristais do PI-II apresentam perfis de An\% em forma de sino invertido, variando de An\% 22,0\% a 24,0\%, para a amostra STX265B, de $26,5 \%$ a $28,7 \%$, para a amostra STX-267 e de $27,0 \%$ a $31,4 \%$, para a amostra STX-282, com todos os valores tendo sido obtidos do centro para a borda dos cristais.

O perfil de anortita em forma de sino normal é um zoneamento já bem conhecido na literatura. Este tipo de zoneamento é formado por um "fracionamento em equilíbrio quando a difusão no cristal se dá de forma incipiente e os componentes estão distribuídos desigualmente em equilíbrio entre o fundido e o cristal" (Loomis, 1982). Contudo, o zoneamento reverso observado nas análises dos cristais da matriz do BMF é difícil de ser explicado, pois há muitas as variáveis que controlam esse tipo de situação. Porém, alguns modelos foram propostos. Sisson e Grove (1993), por exemplo, demonstraram a importância da $\mathrm{H}_{2} \mathrm{O}$ no fundido e o seu papel no controle da cristalização de An\%. 

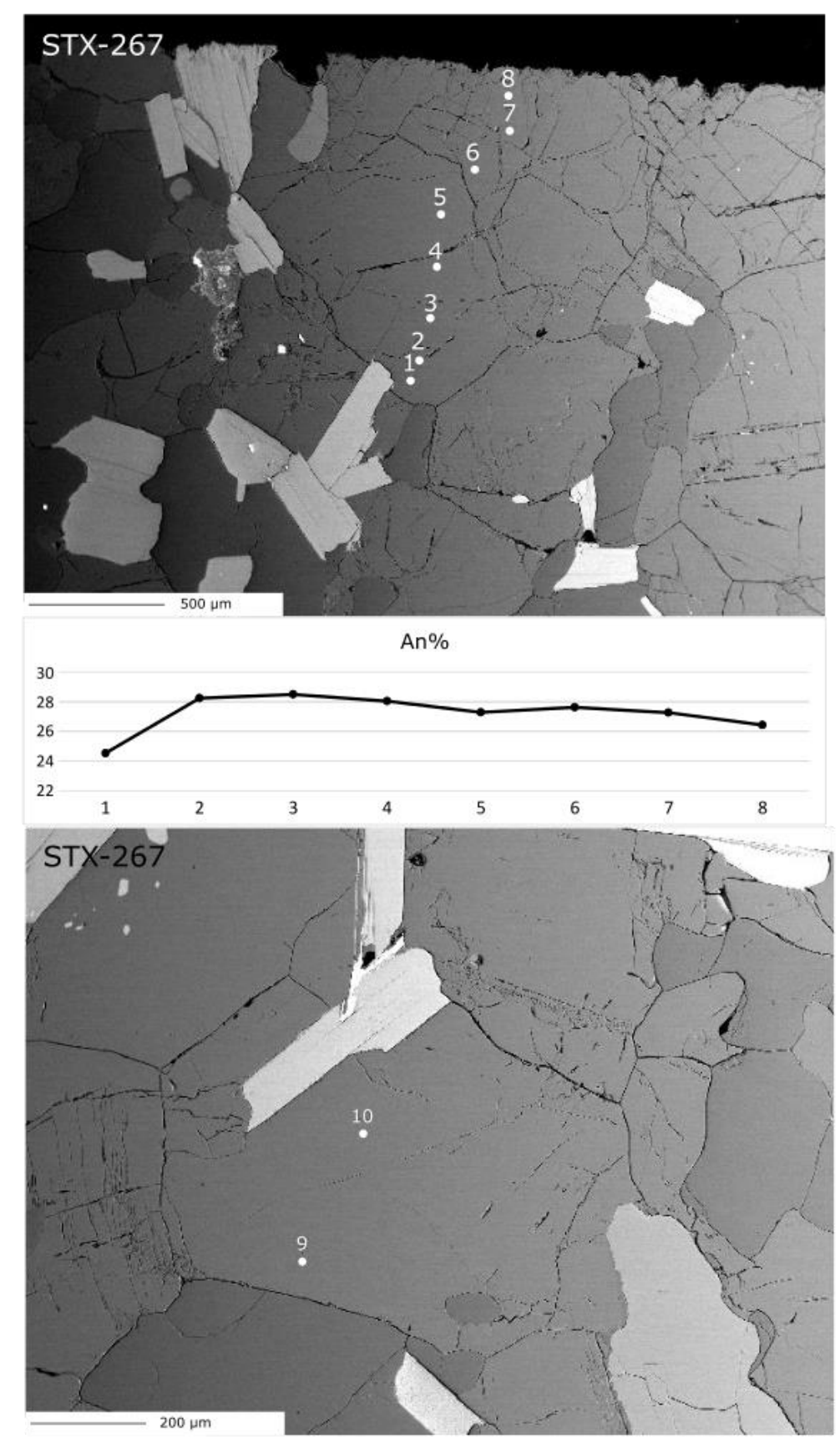

Figura 32 - Fotomicrografias e gráficos composicionais de perfis de análise de plagioclásio. Os números se referem aos pontos analisados. Cristais que tiveram apenas duas análises não tiveram seus perfis representados. Todas as imagens pertencem à amostra STX-267.

Já Glasner (1984) demonstrou que um aumento de temperatura na câmara magmática pode induzir a formação de plagioclásio mais cálcico, criando bordas mais anortíticas no fim da cristalização. Outra possível explicação para a geração de zoneamento inverso pode ser devido a processos de mistura ou de recarga de 
magmas mais primitivos (Shervais e McGee, 1998). Estes autores relatam exemplos de mistura de magmas com zoneamento inverso em anortositos de suítes alcalinas. Neste caso, ocorreria não só um aumento de temperatura do sistema, como faria com que o líquido residual se tornasse mais cálcico, formando assim o zoneamento inverso.

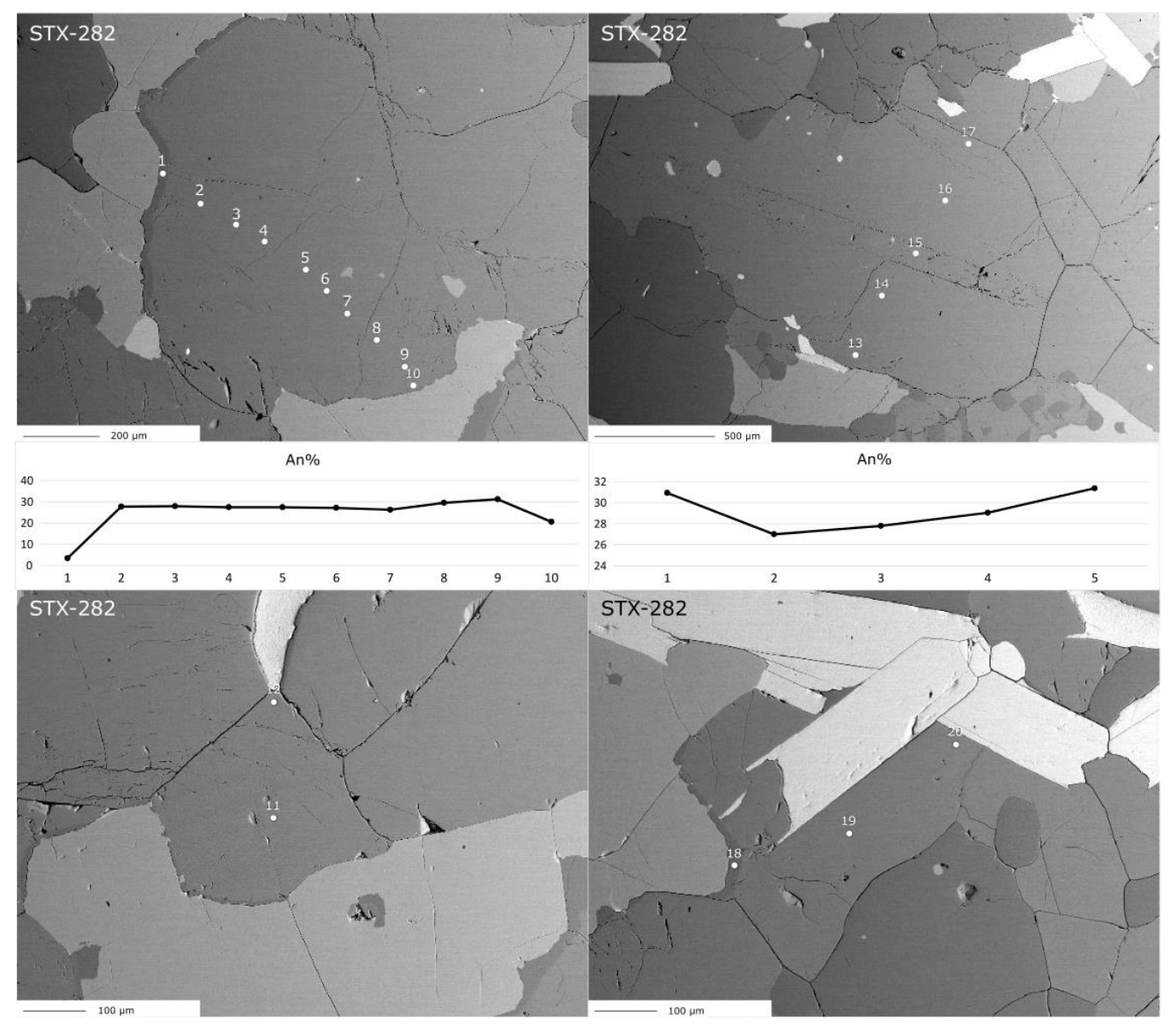

Figura 33 - Fotomicrografias e gráficos composicionais de perfis de análise de plagioclásio. Os números se referem aos pontos analisados. Cristais que tiveram apenas duas análises não tiveram seus perfis representados. Todas as imagens pertencem à amostra STX-282. 
Tabela 6.

Análises quantitativas obtidas por WDS de elementos maiores e traços em plagioclásio do Batólito Muniz Freire.

Amostra:

\begin{tabular}{|c|c|c|c|c|c|c|c|c|c|c|c|c|c|c|c|c|c|c|c|c|}
\hline Ponto & 1 & 2 & 3 & 4 & 5 & 6 & 7 & 8 & 9 & 10 & 11 & 12 & 13 & 14 & 15 & 16 & 17 & 18 & 19 & 20 \\
\hline $\mathrm{SiO}_{2}$ & 62,41 & 62,49 & 62,19 & 61,73 & 61,80 & 61,89 & 61,70 & 62,41 & 62,68 & 62,84 & 64,97 & 68,42 & 62,45 & 62,59 & 62,40 & 62,45 & 62,87 & 63,13 & 62,69 & 62,54 \\
\hline $\mathrm{Al}_{2} \mathrm{O}_{3}$ & 24,66 & 24,59 & 24,89 & 25,00 & 25,12 & 24,96 & 24,84 & 24,62 & 24,42 & 24,35 & 22,87 & 20,44 & 24,50 & 24,57 & 24,46 & 24,35 & 24,10 & 24,12 & 24,02 & 24,41 \\
\hline $\mathrm{Fe}_{2} \mathrm{O} 3$ & 0,04 & 0,09 & 0,03 & 0,05 & 0,06 & 0,11 & 0,03 & 0,03 & 0,01 & 0,09 & 0,03 & 0,07 & 0,07 & 0,00 & 0,05 & 0,08 & 0,06 & 0,08 & 0,09 & 0,09 \\
\hline $\mathrm{MnO}$ & 0,00 & 0,00 & 0,01 & 0,00 & 0,00 & 0,00 & 0,00 & 0,01 & 0,00 & 0,01 & 0,00 & 0,02 & 0,00 & 0,02 & 0,00 & 0,00 & 0,00 & 0,01 & 0,00 & 0,00 \\
\hline $\mathrm{CaO}$ & 5,13 & 5,03 & 5,32 & 5,52 & 5,77 & 5,59 & 5,54 & 5,02 & 4,97 & 4,86 & 3,18 & 0,40 & 5,06 & 5,09 & 4,98 & 4,96 & 4,74 & 4,56 & 4,59 & 5,00 \\
\hline K2O & 0,15 & 0,14 & 0,24 & 0,27 & 0,23 & 0,27 & 0,27 & 0,19 & 0,19 & 0,22 & 0,15 & 0,14 & 0,14 & 0,10 & 0,12 & 0,32 & 0,22 & 0,29 & 0,30 & 0,30 \\
\hline $\mathrm{SrO}$ & 0,09 & 0,07 & 0,06 & 0,04 & 0,07 & 0,01 & 0,06 & 0,03 & 0,08 & 0,05 & 0,03 & 0,01 & 0,09 & 0,06 & 0,04 & 0,07 & 0,04 & 0,07 & 0,04 & 0,04 \\
\hline $\mathrm{TiO}_{2}$ & 0,03 & 0,00 & 0,00 & 0,01 & 0,00 & 0,00 & 0,00 & 0,02 & 0,04 & 0,00 & 0,03 & 0,02 & 0,00 & 0,00 & 0,00 & 0,00 & 0,00 & 0,00 & 0,00 & 0,00 \\
\hline $\mathrm{BaO}$ & 0,01 & 0,03 & 0,04 & 0,00 & 0,07 & 0,00 & 0,00 & 0,04 & 0,03 & 0,08 & 0,02 & 0,00 & 0,01 & 0,00 & 0,02 & 0,05 & 0,05 & 0,00 & 0,02 & 0,00 \\
\hline $\mathrm{Na}_{2} \mathrm{O}$ & 8,50 & 8,55 & 8,32 & 8,24 & 8,12 & 8,18 & 8,22 & 8,64 & 8,48 & 8,69 & 9,72 & 11,23 & 8,67 & 8,60 & 8,69 & 8,57 & 8,69 & 8,75 & 8,67 & 8,54 \\
\hline $\mathrm{MgO}$ & 0,00 & 0,00 & 0,00 & 0,00 & 0,00 & 0,00 & 0,00 & 0,00 & 0,00 & 0,00 & 0,00 & 0,00 & 0,00 & 0,00 & 0,00 & 0,00 & 0,00 & 0,00 & 0,00 & 0,00 \\
\hline Total & 101,03 & 100,99 & 101,09 & 100,86 & 101,24 & 101,01 & 100,66 & 101,02 & 100,89 & 101,19 & 101,00 & 100,75 & 100,99 & 101,03 & 100,75 & 100,85 & 100,77 & 101,02 & 100,42 & 100,92 \\
\hline$A n \%$ & 24,80 & 24,35 & 25,74 & 26,60 & 27,80 & 26,98 & 26,70 & 24,03 & 24,19 & 23,34 & 15,17 & 1,90 & 24,19 & 24,51 & 23,88 & 23,79 & 22,85 & 22,00 & 22,25 & 24,02 \\
\hline
\end{tabular}

Amostra:

STX-267

\begin{tabular}{|c|c|c|c|c|c|c|c|c|c|c|c|c|c|c|}
\hline Ponto & 1 & 2 & 3 & 4 & 5 & 6 & 7 & 8 & 9 & 10 & 11 & 12 & 13 & 14 \\
\hline $\mathrm{SiO}_{2}$ & 62,20 & 61,17 & 61,36 & 61,37 & 61,38 & 61,86 & 61,58 & 61,33 & 60,49 & 60,97 & 67,06 & 61,50 & 61,20 & 61,00 \\
\hline $\mathrm{Al}_{2} \mathrm{O}_{3}$ & 24,42 & 25,07 & 25,06 & 24,89 & 24,72 & 24,76 & 24,90 & 24,71 & 24,87 & 24,89 & 20,70 & 24,80 & 24,86 & 25,08 \\
\hline $\mathrm{Fe}_{2} \mathrm{O}_{3}$ & 0,09 & 0,07 & 0,10 & 0,08 & 0,10 & 0,06 & 0,05 & 0,06 & 0,08 & 0,08 & 0,05 & 0,04 & 0,04 & 0,05 \\
\hline $\mathrm{MnO}$ & 0,00 & 0,01 & 0,02 & 0,00 & 0,00 & 0,01 & 0,00 & 0,00 & 0,00 & 0,00 & 0,01 & 0,00 & 0,00 & 0,00 \\
\hline $\mathrm{CaO}$ & 5,02 & 5,75 & 5,81 & 5,67 & 5,54 & 5,63 & 5,56 & 5,29 & 5,58 & 5,55 & 0,96 & 5,40 & 5,40 & 5,86 \\
\hline K2O & 0,26 & 0,27 & 0,30 & 0,38 & 0,36 & 0,37 & 0,39 & 0,38 & 0,28 & 0,27 & 0,08 & 0,14 & 0,21 & 0,22 \\
\hline $\mathrm{SrO}$ & 0,10 & 0,08 & 0,08 & 0,08 & 0,07 & 0,13 & 0,09 & 0,05 & 0,12 & 0,09 & 0,03 & 0,07 & 0,07 & 0,09 \\
\hline $\mathrm{TiO}_{2}$ & 0,04 & 0,04 & 0,00 & 0,06 & 0,01 & 0,00 & 0,00 & 0,00 & 0,04 & 0,00 & 0,01 & 0,00 & 0,00 & 0,04 \\
\hline $\mathrm{BaO}$ & 0,01 & 0,01 & 0,00 & 0,02 & 0,02 & 0,01 & 0,05 & 0,04 & 0,06 & 0,07 & 0,00 & 0,02 & 0,01 & 0,01 \\
\hline $\mathrm{Na}_{2} \mathrm{O}$ & 8,37 & 7,89 & 7,86 & 7,80 & 7,92 & 7,92 & 7,95 & 7,90 & 7,74 & 8,04 & 10,76 & 8,21 & 8,13 & 7,90 \\
\hline $\mathrm{MgO}$ & 0,00 & 0,00 & 0,00 & 0,00 & 0,00 & 0,00 & 0,00 & 0,00 & 0,00 & 0,00 & 0,02 & 0,00 & 0,00 & 0,00 \\
\hline Total & 100,50 & 100,35 & 100,59 & 100,35 & 100,13 & 100,75 & 100,57 & 99,75 & 99,26 & 99,96 & 99,68 & 100,18 & 99,92 & 100,24 \\
\hline An\% & 24,52 & 28,24 & 28,49 & 28,02 & 27,28 & 27,62 & 27,26 & 26,41 & 27,99 & 27,18 & 4,69 & 26,45 & 26,50 & 28,71 \\
\hline
\end{tabular}


Tabela 7.

Análises quantitativas obtidas por WDS de elementos maiores e traços em plagioclásio do Batólito Muniz Freire

Amostra:

STX-282

\begin{tabular}{|c|c|c|c|c|c|c|c|c|c|c|c|c|c|c|c|c|c|c|c|c|}
\hline Ponto & 1 & 2 & 3 & 4 & 5 & 6 & 7 & 8 & 9 & 10 & 11 & 12 & 13 & 14 & 15 & 16 & 17 & 18 & 19 & 20 \\
\hline $\mathrm{SiO}_{2}$ & 68,35 & 61,63 & 61,55 & 61,91 & 61,82 & 61,90 & 62,21 & 61,50 & 60,76 & 63,30 & 61,56 & 60,57 & 61,08 & 61,89 & 61,72 & 61,18 & 60,59 & 68,18 & 61,84 & 60,33 \\
\hline $\mathrm{Al}_{2} \mathrm{O}_{3}$ & 20,59 & 25,29 & 25,06 & 25,08 & 25,18 & 25,05 & 24,99 & 25,61 & 25,70 & 24,20 & 25,72 & 25,81 & 25,62 & 25,11 & 25,12 & 25,34 & 26,05 & 20,65 & 25,12 & 25,82 \\
\hline $\mathrm{Fe}_{2} \mathrm{O}_{3}$ & 0,00 & 0,17 & 0,10 & 0,11 & 0,11 & 0,08 & 0,00 & 0,01 & 0,09 & 0,01 & 0,11 & 0,12 & 0,10 & 0,13 & 0,14 & 0,08 & 0,13 & 0,05 & 0,15 & 0,23 \\
\hline $\mathrm{MnO}$ & 0,01 & 0,01 & 0,02 & 0,03 & 0,00 & 0,00 & 0,01 & 0,00 & 0,00 & 0,00 & 0,00 & 0,01 & 0,01 & 0,01 & 0,00 & 0,00 & 0,01 & 0,01 & 0,00 & 0,00 \\
\hline $\mathrm{CaO}$ & 0,70 & 5,64 & 5,69 & 5,60 & 5,61 & 5,62 & 5,37 & 6,12 & 6,40 & 4,26 & 6,11 & 6,57 & 6,42 & 5,53 & 5,73 & 5,95 & 6,44 & 0,65 & 5,56 & 6,51 \\
\hline $\mathrm{K}_{2} \mathrm{O}$ & 0,10 & 0,26 & 0,28 & 0,24 & 0,20 & 0,17 & 0,18 & 0,13 & 0,12 & 0,13 & 0,15 & 0,12 & 0,25 & 0,36 & 0,31 & 0,36 & 0,21 & 0,09 & 0,21 & 0,14 \\
\hline $\mathrm{SrO}$ & 0,04 & 0,07 & 0,06 & 0,07 & 0,09 & 0,06 & 0,06 & 0,08 & 0,10 & 0,08 & 0,10 & 0,08 & 0,10 & 0,09 & 0,05 & 0,07 & 0,11 & 0,03 & 0,10 & 0,10 \\
\hline $\mathrm{TiO}_{2}$ & 0,05 & 0,00 & 0,01 & 0,02 & 0,00 & 0,00 & 0,00 & 0,00 & 0,00 & 0,04 & 0,04 & 0,03 & 0,01 & 0,00 & 0,00 & 0,05 & 0,00 & 0,04 & 0,01 & 0,02 \\
\hline $\mathrm{BaO}$ & 0,03 & 0,05 & 0,04 & 0,04 & 0,00 & 0,03 & 0,00 & 0,08 & 0,00 & 0,00 & 0,00 & 0,03 & 0,04 & 0,01 & 0,02 & 0,00 & 0,00 & 0,05 & 0,00 & 0,02 \\
\hline $\mathrm{Na}_{2} \mathrm{O}$ & 11,13 & 7,94 & 7,96 & 8,05 & 8,08 & 8,26 & 8,22 & 7,99 & 7,72 & 9,00 & 7,92 & 7,69 & 7,76 & 8,03 & 8,03 & 7,80 & 7,64 & 11,19 & 8,15 & 7,68 \\
\hline $\mathrm{MgO}$ & 0,01 & 0,00 & 0,00 & 0,00 & 0,00 & 0,00 & 0,00 & 0,00 & 0,00 & 0,00 & 0,00 & 0,00 & 0,00 & 0,00 & 0,00 & 0,00 & 0,00 & 0,00 & 0,00 & 0,00 \\
\hline Total & 101,01 & 101,05 & 100,77 & 101,14 & 101,09 & 101,16 & 101,04 & 101,52 & 100,89 & 101,02 & 101,70 & 101,02 & 101,39 & 101,16 & 101,11 & 100,82 & 101,19 & 100,94 & 101,14 & 100,84 \\
\hline An\% & 3,35 & 27,73 & 27,86 & 27,38 & 27,40 & 27,07 & 26,25 & 29,53 & 31,20 & 20,56 & 29,64 & 31,85 & 30,93 & 26,99 & 27,79 & 29,04 & 31,37 & 3,10 & 27,03 & 31,63 \\
\hline
\end{tabular}


8.5.3.2 Relação entre zoneamento do plagioclásio e dissolução do epídoto

Porém, outra possibilidade não considerada pelos autores acima é que o enriquecimento de cálcio no magma possa ter sido fornecido pela dissolução do epídoto, conforme será discutido a seguir. Como já foi exposto no capítulo referente ao epídoto, este mineral é estável em composições tonalíticas, porém metaestável em composições granodioríticas, no caso do BMF. Além disso, em pressões inferiores ao seu campo de estabilidade, o epídoto, quando em contato com o líquido residual, é reabsorvido e se cristaliza em outras fases, o que pode ocorrer durante a ascensão do magma. É possível que o epídoto, nas fases finais da cristalização, ao ser reabsorvido pelo líquido, enriqueça o líquido final em cálcio, possibilitando a cristalização de uma borda mais anortítica ao redor do núcleo menos anortítico. Porém, isso só ocorreria nos cristais da segunda geração (PI-II), os quais se assemelham a uma geração tardia. Além disso, pode-se assumir que a única área afetada pela dissolução do epídoto seria a borda mais anortítica cristalizada após a dissolução do mesmo. Para ilustrar isso, faz-se necessário discutir a possibilidade dessa hipótese.

A reação de dissolução do epídoto (na ausência de hornblenda) é aquela demonstrada por Schmidt e Poli (2004), que será considerada na discussão abaixo:

$$
\begin{aligned}
& \text { Epídoto }+ \text { Biotita }+(\text { Quartzo })_{\text {fundido }}+\text { tschermak }- \text { exchange }[b t]=(K- \\
& \text { feldspato })_{\text {fundido }}+\text { Plagioclásio }(A n)+\mathrm{H}_{2} \mathrm{O}
\end{aligned}
$$

Inserindo-se a composição de epídoto da amostra STX-282, de biotita da amostra PMF-14A (tabela 8, amostra com epídoto, assumindo como aproximação uma homogeneidade composicional desse mineral para todo o corpo) e supondose que o quartzo, feldspato alcalino e plagioclásio (An) estarão em suas composições ideais, com o balanço estequiométrico podendo ser expresso assim: 


$$
\begin{gathered}
\mathrm{Ca}_{2}\left(\mathrm{Al}_{2} \mathrm{Fe}^{3+}\right)\left(\mathrm{Si}_{2} \mathrm{O}_{7}\right)\left(\mathrm{SiO}_{4}\right) \mathrm{O}(\mathrm{OH})+\mathrm{K}\left(\mathrm{Fe}_{1,5} \mathrm{MgAl}_{0,5}\right) \mathrm{AlSi}_{3} \mathrm{O}_{10}(\mathrm{OH})_{2}+ \\
2 \mathrm{SiO}_{2}+\mathrm{Al}_{2} \mathrm{Mg}_{-1} \mathrm{Si}_{-1}=\mathrm{KAlSi}_{3} \mathrm{O}_{8}+2 \mathrm{CaAl}_{2} \mathrm{Si}_{2} \mathrm{O}_{8}+1,5 \mathrm{H}_{2} \mathrm{O}+0,5 \mathrm{FeO}+\mathrm{Fe}_{2} \mathrm{O}_{3}
\end{gathered}
$$

Para cada mol de epídoto, formam-se dois mols de anortita.

\section{Tabela 8.}

Análises quantitativas obtidas por WDS em biotita da amostra PMF-14A do Batólito Muniz Freire

\begin{tabular}{|c|c|c|c|c|c|c|c|c|c|c|c|c|}
\hline $\mathrm{Si}$ & $\mathrm{Al}$ & $\mathrm{Fe}$ & $\mathrm{Mn}$ & $\mathrm{Cl}$ & $\mathrm{K}$ & $\mathrm{Ca}$ & $\mathrm{S}$ & $\mathrm{Ti}$ & $\mathrm{F}$ & $\mathrm{Na}$ & $\mathrm{Mg}$ & $\mathrm{O}$ \\
\hline $\mathbf{3 4 , 9 2}$ & $\mathbf{1 6 , 3 1}$ & $\mathbf{2 4 , 0 8}$ & $\mathbf{0 , 4 7}$ & $\mathbf{0 , 0 4}$ & $\mathbf{1 0 , 0 3}$ & $\mathbf{0 , 0 3}$ & $\mathbf{0 , 0 7}$ & $\mathbf{2 , 6 8}$ & $\mathbf{0 , 0 0}$ & $\mathbf{0 , 0 7}$ & $\mathbf{7 , 0 0}$ & - \\
\hline
\end{tabular}

Na amostra STX-282 foi quantificada a proporção entre PI-I e PI-II, cuja análise modal resultou: $30,5 \%$ de quartzo, $23,5 \%$ de feldspato alcalino, $6,5 \%$ de biotita e $39,5 \%$ de plagioclásio. Do total de plagioclásio, $18,8 \%$ são de cristais semelhantes ao PI-I e 20,7\%, ao PI-II. Além disso, como demonstrado na figura 34, um cristal de $\mathrm{PI}-\mathrm{II}$ pode ser separado em uma borda que corresponde a $43 \%$ de sua área e um núcleo que corresponde a $57 \%$ da mesma.

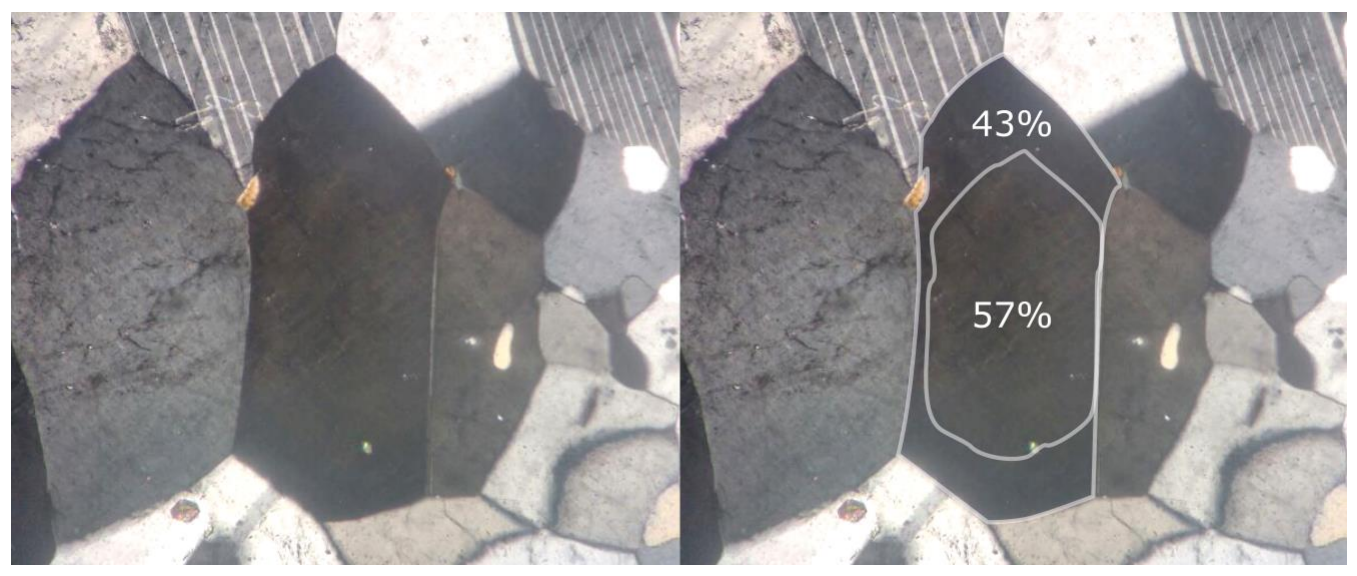

Figura 34 - Fotomicrografia de cristal de plagioclásio com zoneamento inverso. Foi realizado o cálculo da área que corresponde ao núcleo do cristal e à borda do mesmo.

Essa aproximação pode ser considerada um pouco grosseira, pois ela considera o cristal apenas em duas dimensões, não em suas três dimensões, e também não considera os diferentes cristais com proporções distintas de núcleo e borda. Porém, mesmo levando em conta essas aproximações, as proporções entre a borda e o núcleo do cristal não devem variar mais do que 10\%. Para referência, será designado o núcleo desses cristais como PI-II e a borda como PI-III. Sendo assim, pode-se assumir que, quando da dissolução do epídoto, 8,9\% do total de plagioclásio na rocha se encontrava no estado líquido e que apenas esta parcela 
seria afetada por esse processo. A figura 35 apresenta um modelo de cristalização que mostra como teriam se cristalizado as diferentes fases nas diferentes gerações.

Assumindo-se que o líquido (figura 35, segundo quadro), antes da dissolução do epídoto, teria composição semelhante à do núcleo dos cristais, pode-se utilizar os pontos 11 e 12 da tabela 7 como referência das composições de centro e borda dos mesmos, onde a variação de An é de 2,21\%. Para gerar essa variação, precisaria adicionar $\sim 0,19 \%$ de anortita no sistema, o que requereria a dissolução de $\sim 0,17 \%$ do total da rocha em epídoto. Este valor é perfeitamente compatível com a proporção de epídoto presente nas rochas granodioríticas do BMF, considerando também que o epídoto foi consumido apenas parcialmente e, para a maioria das amostras, restaria ainda entre $1,1 \%$ desse mineral. Além disso, a diferença da proporção de epídoto entre granodioritos, onde esse mineral está parcialmente reabsorvido, e tonalitos, onde epídoto está preservado, é de aproximadamente $3,6 \%$. Este valor fornece uma aproximação da disponibilidade de epídoto originalmente na rocha e a proporção máxima que poderia ser consumida. 

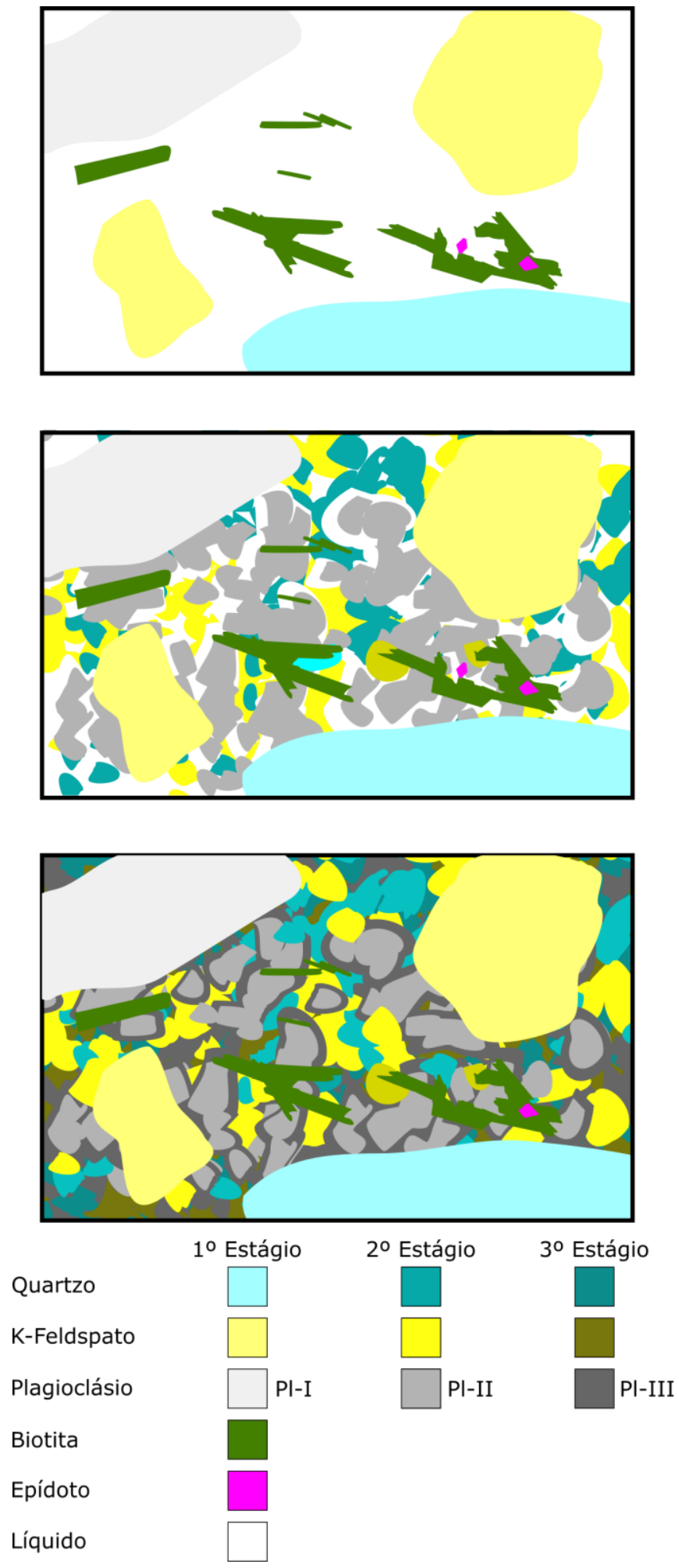

Figura 35 - Modelo de cristalização para o BMF. As fases precoces correspondem aos minerais precoces como biotita e epídoto (titanita, hornblenda, apatita, zircão e allanita não estão representados) e fenocristais dos minerais félsicos. O líquido presente restante após o segundo estágio de cristalização corresponde ao líquido afetado pela dissolução do epídoto. Apesar de não ser possível determinar a proporção líquido rocha quando da dissolução, foi possível determinar a proporção de PI-III vs. PI-total. 


\section{DISCUSSÃO DE ORIGEM PARA O BATÓLITO MUNIZ FREIRE}

Os parâmetros isotópicos (De Campos, 2004) do BMF são consistentes com uma evolução associada com magmas gerados a partir da fusão parcial de rochas crustais, com participação de processos de diferenciação, como cristalização fracionada de minerais ferro-magnesianos (anfibólio, biotita), plagioclásio e feldspato alcalino. Granitos com estas características são comumente gerados em cinturões orogênicos formados por colisão continental. Os magmas representativos deste tipo de associação podem ser formados durante ou após o ápice da colisão ou no período de soerguimento e relaxamento póscolisional (England \& Thompson, 1986; Barbarin, 1999; Liegeois, 1998; PatiñoDouce \& McCarthy, 1998). Isso pode ocorrer também com granitoides do tipo Cordilherano, onde o processo de subducção com crosta continental espessada pode gerar magmatismo com feições geoquímicas e isotópicas com características de fonte crustal, razão pela qual esse tipo de ambiente tectônico não pode ser totalmente descartado.

As características geoquímicas e mineralógicas do BMF apontam para um granito do tipo-I, cálcico-alcalino, alto-K a shoshonítico, com A/CNK entre 1,0 e 1,2, incluindo a presença de hornblenda nas amostras menos diferenciadas. Os diagramas de discriminação de ambientes tectônicos (Figuras $14 \mathrm{~A}$ e B) não foram capazes de discriminar com clareza o ambiente tectônico de geração do BMF (ou mesmo do Batólito Galiléia), com as amostras situando-se tanto em ambiente pré, sin- ou mesmo pós-colisional.

Considerando a classificação da granitogênese proposta para o Orógeno Araçuaí por Pedrosa Soares e colaboradores $(1998,2001,2011)$, que dividem o magmatismo em cinco suítes (G1 a G5), a partir do mais antigo para o mais novo; G1 - pré-colisionais (625-595 Ma), G2 - sincolisionais (580-560 Ma, com pico 575 Ma), G3-I e G3-S - tardi- a pós-coliisonais (560-530 Ma) e as suítes G4 e G5- tardia pós-tectônicas (pós-colisionais), com idades entre 530 a 500 Ma e 500 a $480 \mathrm{Ma}$, respectivamente, o magmatismo relacionado ao BMF, com idade $\mathrm{U}-\mathrm{Pb}$ de $588 \pm 4$ Ma. Considerando a margem de erro da idade - o BMF poderia pertencer tanto a Suíte G1 quanto a Suíte G2, pois o limite entre elas se encontra em 585 Ma. Portanto, segundo esta classificação, o BMF poderia ser tanto representante do magmatismo pré-colisional (G1) e neste caso seria relacionado à subducção da litosfera oceânica associada à orogenia Rio Doce, cujo representante clássico é o 
Batólito Galiléia, como poderia estar relacionado ao magmatismo sin-colisional, cujos representantes são os granitoides tipo-S (G2), a exemplo do Batólito Urucum, com idade U-Pb em zircão de $582 \mathrm{Ma} \pm 2 \mathrm{Ma}$ (Nalini et al. 2000, 2005).

Gonçalves et al. (2016), em trabalho sobre a terminação norte do arco magmático Rio Doce, subdividem a suíte G1 em duas, uma primeira de idade entre $630 \mathrm{Ma}$ e $590 \mathrm{Ma}$, com evidências de migmatização, e outra entre 590 e $570 \mathrm{Ma}$, sem essas evidências, restringindo um evento de alta temperatura à idade de 585 Ma para essas rochas. Nesse caso, há uma sobreposição de $20 \mathrm{Ma}$ entre o fim do evento gerador da Suíte G1 e o início do evento gerador da Suíte G2.

Para um magmatismo com características pré-colisionais, espera-se que tenham características semelhantes aos dos grandes batólitos andinos, com magmatismo menos evoluído, incluindo maior proporção de rochas menos diferenciadas, onde o magmatismo tipo-I Cordilherano possui a relação gabrodiorito/tonalito-granodiorito/granito de 15:50:35, respectivamente (Pitcher, 1992). Embora não tenha sido estabelecida ainda esta relação para as suítes graníticas pré-colisionais do Orógeno Araçuaí, considera-se que há uma proporção muito diferente da estabelecida para os batólitos andinos, devendo se aproximar mais daquela considerada para o magmatismo tipo-I Caledoniano, que é de 2:18:80, respectivamente (Pitcher 1992). Os dados isotópicos dos batólitos andinos apresentam em vários lugares valores de $\varepsilon N d$ negativos (-2 a -6,), como aqueles do Sul da Patagônia, de idades jurássica (157-145 Ma) e cretácica (144-137 Ma), e razões $\mathrm{Sr}^{87} / \mathrm{Sr}^{86}$ entre 0,707 a 0,709 (Pankhurst et al., 1999; Hervé et al., 2007), as quais se repetem também nos andes peruanos, particularmente no segmento Arequipa (Moore e Agar, 1985; Beckinsale et al., 1985). Valores mais negativos de $\varepsilon N d$ (até -11) e razões mais elevadas de $\mathrm{Sr}^{87} / \mathrm{Sr}^{86}$ (até 0,716 ) são reportados para a região norte da Península Antártica e para o norte do Chile (Pankhurst et al., 1988), sugerindo assim importante participação crustal na geração do magmatismo de vários segmentos dos batólitos andinos.

Magmas intermediários a ácidos podem se formar por diversos processos em arcos magmáticos de margem continental, envolvendo também fusão parcial da crosta e assimilação da mesma e misturas entre magmas de composições diferentes, como magmas félsicos e máficos. Inclusive, esses processos ocorrem normalmente em conjunto em arcos magmáticos, podendo apresentar maior ou 
menor relevância. Isso torna difícil a diferenciação de quais deles ocorreram ou não a partir apenas de análises do resultado final. (Murphy, 2007).

Ao considerar-se a geração das suítes pré-colisionais no contexto do Orógeno Araçuaí, Pedrosa-Soares et al., (1999) propõem a existência de uma subducção de litosfera oceânica como processo inicial de formação do Orógeno Araçuaí, apoiando-se em duas evidências principais: a presença de lascas ofiolíticas descritas na Formação Ribeirão da Folha e de um arco magmático com formação de granitoides cálcico-alcalinos, tendo o Batólito Galiléia como principal representante. Além disso, conforme evoluíram os estudos do Orógeno Araçuaí (Pedrosa-Soares et al., 2001, 2007, 2008, 2011, Pedrosa e Wiedemann-Leonardos, 2000, De Campos et al., 2004), foram delimitados intervalos distintos de idades desse magmatismo, conforme acima mencionado. Os autores concluem pela presença de um evento de subducção oceano-continente, sucedido por um evento colisional continente-continente. Este modelo tem sido aprimorado pelos autores e, embora seja bem aceito na literatura para a evolução do Orógeno Araçuaí, a classificação tectônica das suítes graníticas, particularmente das suítes G1 e G2, bem como a natureza e o ambiente tectônico de geração das mesmas, são questões ainda não devidamente esclarecidas. Além disso, a idade de $585 \mathrm{Ma}$ sugerida como limite para separar estas duas suítes não se sustenta com base nos dados geocronológicos de alta precisão disponíveis sobre as mesmas, pois este limite situa-se dentro da margem de erro das idades U-Pb em zircões obtidas nessas rochas.

Como descrito acima, os granitoides formados em ambiente de subducção em margem continental ativa, como a dos Andes, podem apresentar valores isotópicos relativamente negativos de $\varepsilon N d$ (até -11) e elevadas razões de $\mathrm{Sr}^{87} / \mathrm{Sr}^{86}$ (até 0,716 ), sugerindo forte interação crustal do magma gerado nestas condições, podendo mesmo assimilar parte da crosta continental e até produzir a sua fusão parcial. A presença de idades $\mathrm{U} / \mathrm{Pb}$ herdadas ao redor de 2,1 $\mathrm{Ga}$, obtidas em núcleos de zircão (Nalini et al., 2000, Gonçalves et al., 2014) reforçam este tipo de interpretação. Os dados isotópicos disponíveis para os granitos da Suíte G1 do Orógeno Araçuaí mostram também elevadas razões isotópicas de $\operatorname{Sr}(-5,8$ a -12,9) e valores sempre negativos de $\varepsilon N d$ (-5,8 a -12,9) (Nalini, 1997; Martins et al., 2004; Novo et al., 2010). Estes valores são comparáveis aos de alguns batólitos andinos e também aos dos granitos tipo-S ( $\varepsilon N d$ entre $-5,8$ a $-8,8$ e razões de $\mathrm{Sr}^{87} / \mathrm{Sr}^{86}$ entre 
708-0,712) do Cinturão Lachlan na Austrália (Chappell \& White, 2001). As idades modelo disponíveis para rochas da Suíte G1 mostram valores no intervalo de 1,2 a 2,1 Ga, concentrando-se principalmente entre 1,8 a 2,1 Ga (Nalini, 1997; Novo et al., 2010; Pedrosa-Soares et al., 2011). Estas idades TDM (600Ma) foram interpretadas por Nalini, (1997) como sendo idades de extração do manto dos protólitos que deram origem aos granitoides da Suíte Galiléia. Este autor obteve também idades $\mathrm{U} / \mathrm{Pb}$ de 2,2 \pm 0,3 Ga em núcleos de zircão nas fácies Urucum e Palmital da Suíte Urucum (G2, na classificação de Pedrosa-Soares e Wiedemann, 2000; PedrosaSoares et al., 2001 e 2011), interpretadas como idades de cristalização dos protólitos que deram origem aos granitos peraluminosos da referida suíte (Nalini, 1997). Assimilação crustal de rochas encaixantes como os paragnaisses do Complexo Paraíba do Sul pode também ter contribuído para o caráter marginalmente peraluminoso do BMF.

Os granitos da Suíte G1 apresentam foliação com deformação no estado sólido que localmente passam para uma foliação milonítica, bem como preservam também uma foliação de fluxo magmático bem desenvolvida, particularmente na parte central dos corpos (Nalini, 1997; Nalini et al., 2005; Pedrosa-Soares et al., 2011). Muitas das colocações desses corpos são controladas por zonas de cisalhamento dúcteis de alto ângulo. Nas porções dos corpos onde a deformação é incipiente, texturas ígneas predominam, porém orientadas, indicando que a cristalização se deu durante fases ativas das zonas de cisalhamento que controlam a colocação desse magmatismo (Nalini, 1997, Nalini et al., 2005, Suarez Rojas, 2011, Gonçalves et al., 2016). Para o BMF, isso está bem registrado, coexistindo texturas de deformação dinâmica relacionadas à Zona de Cisalhamento Guaçuí com texturas ígneas não deformadas. Espera-se para granitos pré-colisionais, relacionados com a subducção de uma litosfera oceânica, que eles estejam deformados, pois após a sua geração e fechamento do oceano ocorre a colisão dos continentes, seguida pelo espessamento crustal e aumento de temperatura do orógeno, produzindo assim intensa deformação desses corpos, o que aparentemente não ocorre de forma generalizada nos granitos da Suíte G1.

Esses aspectos não excluem a possibilidade de ter ocorrido subducção durante a evolução tectônica do Orógeno Araçuaí, a julgar pela existência de 'lascas ofiolíticas' na Formação Ribeirão da Folha (Pedrosa-Soares et al., 2001, 2011). Outra possibilidade de origem para os granitoides tipo-I pode estar 
relacionada com a fusão de uma crosta ortognáissica de composição tonalítica. A fusão parcial desse tipo de crosta pode gerar magmas de composição geoquímica idêntica ao do seu protólito, particularmente em termos dos elementos maiores, com possíveis diferenças para elementos menores e traços, dependendo das condições em que se deu essa fusão (García-Arias et al., 2012). Isso pode acontecer adjacente a zona de subducção, em orógenos de margem continental do tipo andino, onde o magma básico gerado pelo metassomatismo do manto passa a ser a fonte de calor necessária para promover a fusão parcial da crosta continental. Contudo, a fusão parcial de crosta ortognáissica não é um processo exclusivo de ambientes de subducção, podendo ocorrer também em zonas de espessamento crustal, como em orógenos colisional ou intraplaca. Portanto, se os granitoides tipo-I do Orógeno Araçuaí foram gerados em um estágio sin-colisional, isso explicaria não só os dados isotópicos de $\mathrm{Sr}$ e $\mathrm{Nd}$, que são compatíveis com fusão de protólitos crustais (Nalini, 1997), mas também a preservação de texturas magmáticas nos corpos graníticos da Suíte G1, que são incompatíveis com uma deformação regional relacionada com um processo de colisão continental.

Apesar dessas evidências favoráveis a uma gênese relacionada à fusão parcial de crosta ortognáissica com crosta espessada, os dados de saturação de apatita $\left(\sim 950^{\circ} \mathrm{C}\right)$ indicam que a temperatura inicial do magma era relativamente alta, sugerindo que uma fonte de calor atuou na base da crosta para desencadear a fusão parcial que gerou os magmas, modelo este que é mais simples de ser explicado do que num cenário envolvendo subducção de litosfera oceânica. Contudo, a geração desse tipo de magmatismo pode também ser explicada por outros mecanismos, como a presença de anomalias térmicas no manto. Outra questão dificilmente de ser compatibilizada pelo modelo de subducção, uma vez os granitoides tipo-I e tipo-S ( $G 1$ e G2) não só encontram intimamente relacionados, mas também cronologicamente, mostrando sobreposição de idades entre os diversos corpos.

\section{CONCLUSÕES}

Conclui-se que o BMF é um corpo composto principalmente por biotitamonzogranito a biotita-hornblenda tonalito, apresentando subordinadamente sienogranito. Apresenta estrutura com bandamento milimétrico, textura porfirítica e granulação fina a média. São rochas cálcico-alcalinas alto-K a shoshoníticas e fracamente peraluminosas. O metamorfismo com temperaturas próximas de $650^{\circ} \mathrm{C}$ 
teve pouca influência nas mudanças composicionais da rocha. Nota-se variação da deformação, apresentando porções com textura ígnea bem preservada e porções com deformação dúctil bem desenvolvida. Isso indica que a deformação no BMF foi heterogênea, o que é compatível com a deformação associada a zonas de cisalhamento. Observa-se que as deformações são mais intensas próximas à Zona de Cisalhamento Guaçuí. A progressão da recristalização dinâmica sugere que metamorfismo regional não foi o responsável por essas feições. Além disso, o bandamento apresentado em toda a extensão do batólito parece ter sido gerado, em maior ou menor grau, por uma combinação da deformação acima descrita com estruturas de fluxo magmática.

A presença de epídoto magmático é indicativo de altas pressões (> $8 \mathrm{kbar}$ ), sugerindo que o BMF (e provavelmente o Batólito Galiléia) intrudiu numa crosta espessada e se colocou em profundidades superiores a $24 \mathrm{~km}$. Porém, o epídoto magmático não é estável em todas as composições, sendo metaestável em granodioritos, preservando-se parcialmente em rochas desta composição, e sendo estável em tonalitos, onde se preserva completamente. O magma então iniciou sua cristalização - lembrando que epídoto é uma fase precoce no BMF - em condições de P-T onde o epídoto era estável em ambas as composições, mas terminou de se cristalizar em condições P-T inferiores. Isso ocorre quando a condição de ascensão do magma é suficientemente rápida para que o epídoto permanecesse instável nos granodioritos, porém o líquido não foi suficientemente capaz de dissolvê-lo completamente. Essa situação é compatível com a colocação do BMF em zona de cisalhamento, já que esse tipo de estrutura poderia facilitar a ascensão desse magma tão rico em sílica.

O zoneamento inverso dos cristais de plagioclásio da matriz (PI-II) pode ser explicado pela dissolução do epídoto durante a ascensão do magma, sendo isso, a nosso ver, mais compatível do que os modelos disponíveis na literatura para explicar essa feição (mistura e recarga de magma, aumento da temperatura e hidratação).

Apesar de granada ser um mineral raro no BMF, sua composição é relevante no caso estudado. São três as composições mais comuns para granada em rochas ígneas e metaígneas: Almandina, com pequenas quantidades de outros endmembers; Almandina + Piropo, com Grossulária $<25 \%$ e Espessartita $<10 \%$ e; Almandina+Espessartita com Piropo $<10 \%$ e Grossulária $<10 \%$. A composição de 
granada no BMF é distinta da grande maioria das amostras consideradas para rochas ígneas e metaígneas, porém semelhante à de algumas rochas referidas na literatura mundial. O Batólito Galileia, o Tonalito Bushy Point (Alaska) e os metagranitos do Orógeno Dabie-Sul (China) apresentam granada de composição semelhante à do BMF e compartilham duas características em comum: colocação em altas pressões e a presença de epídoto magmático. Estudos adicionais são necessários para explicar como essas características em comum e a formação da granada se relacionam no mesmo magma. Outra possibilidade é que esses cristais de granadas sejam xenocristais.

Os dados obtidos para o BMF mostram uma notável semelhança com o Batólito Galiléia, sugerindo que ambos tenham sido gerados por fusão de uma crosta de idade predominantemente riaciana e com possível assimilação de paragnaisses do Complexo Paraíba do Sul. A colocação desses batólitos foi controlada por zonas de cisalhamento de alto ângulo e a atividade dessas estruturas foi responsável pela deformação heterogênea das rochas desses batólitos. Os dados aqui discutidos sugerem uma origem comum para eles e possivelmente num ambiente sin-colisional, de forma diferente ao que tem sido proposto na literatura.

\section{REFERÊNCIAS BIBLIOGRÁFICAS}

Almeida, F. F. M. (1967). Origem e evolução da plataforma brasileira. Rio de Janeiro: DNPM-DGM, 241.

Almeida, F. F. M. (1977) O Cráton do São Francisco. Revista Brasileira de Geociências, 7, 349-364.

Alonso-Perez, R., Müntener, O., Ulmer, P. (2009). Igneous garnet and amphibole fractionation in the roots of island arcs: experimental constraints on andesitic liquids. Contributions to Mineralogy and Petrology, 157, 541-558.

Avé'Lallement H. G., Carter N. L. (1971). Pressure dependence of quartz defformation lamellae orientation. American Journal of Science, 270, 218-235

Bachelor, R. A., Bowden, P. (1985). Petrologic interpretation of granitoid rocks series using multicationic parameters. Chemical Geology, 48, 43-55.

Barbarin, B. (1999). A review of the relationships between granitoid types, their origins and their geodynamic environments. Lithos, 605, 605-626. 
Beckinsale, R. D., Sanchez-Fernandez, A. W., Brook, M., Cobbing, E. J., Taylor, W. P., Moore, N. D. (1985). Rb-Sr whole rock isochron and K-Ar age determinations for the Coastal Batholith of Peru. In: Pitcher, W., Artherton, M. P., Cobbing, E. J., Beckinsale, R. D. (eds). Magmatism at a Plate Edge: the Peruvian Andes. John Wiley and Sons.

Moore, N. D., Agar, R. A. (1985). Variations along a batholith: the Arequipa segment of the Coastal Batholith of Peru. In: Pitcher, W., Artherthon, M. P., Cobbing, E. J., Beckinsale, R. D., (eds.). Magmatism at a Plate Edge: the Peruvian Andes. John Wiley and Sons.

Campos Neto, M. C., Figueiredo, M. C. H. (1990). Evolução geológica dos terrenos Costeiro, Paraíba do Sul e Juiz de Fora (RJ-MG-ES). Congresso Brasileiro de Geologia., 36, Anais...Natal, SBG, 6, 2631-2648.

Campos-Neto, M. C., Figueiredo, M. C. H. (1995) The Rio Doce orogeny, southeastern Brazil. Journal South American Earth Science, 8,143-162.

Chappell B. W., White, A. J. R. (1992). I- and S-type granites in the Lachlan Fold Belt. Transactions of the Royal Society of Edinburgh: Earth Sciences, 83, 1-26

Chappel, B.W., White, A.J.R., Wyborn, D. (1987). The importance of residual source material (restite) in granite petrogenesis. Journal Petrology, 28, 111-118.

Costa, A. G., Rosière, C. A., Moreira, L. M., Fischel, D. P. (1995). Caracterização geotectônica do setor setentrional do Cinturão Ribeira: Evidência de acresção neoproterozóica no leste de Minas Gerais. Geonomos 3, 51-68

Ebert, H. (1968) Ocorrências de fácies granulíticas no sul de Minas Gerais e em áreas adjacentes em dependência da estrutura orogênica: hipóteses sobre sua origem. Anais da Academia Brasileira de Ciências, 40, 215-229.

England, P. C. \& Thompson, A. B. (1984). Pressure-Temperature-Time Paths of Regional Metamorphism I: Heat Transfer during the Evolution of Regions of Thickened Continental Crust. Journal of Petrology, 25: 894-928.

Féboli, W. L. (1993) Mapa geológico da Folha Domingos Martins - SF24-V-A-III. Programa de Levantamentos Geológicos Básicos do Brasil, DNPM/CPRM. Escala 1:100.000. Brasília: Companhia de Pesquisa de Recursos Minerais/CPRM. 
Figueiredo, M. C. H, Campos-Neto, M. C. (1991). Geoquímica dos Granitóides de Muniz Freire, ES. Resumos do 3º Congresso Brasileiro de Geoquímica. 245-248. São Paulo:SBGq.

Figueiredo, M. C. H., Campos-Neto, M. C. (1993). Geochemistry of the Rio Doce magmatic arc, Southeastern Brazil. Anais da Academia Brasileira de Ciências, 65, 63-81.

García-Arias, M., Corretgé, L. G., Castro, A. (2012). Trace elemento behavior during partial melting of Iberian orthogneisses: An experimental study. Chemical Geology, 292-293, 1-17.

Sarbas, B. (2008). The GEOROC database as part of a growing geoinformatics network. In: Brady, S.R., Sinha, A.K., and Gundersen, L.C. (eds). Geoinformatics 2008-Data to Knowledge, Proceedings: U.S. Geological Survey Scientific Investigations Report 5172, 42-43.

Glasner F. A. (1984). Activities of olivine and plagioclase components in silicate melts and their application to geothermometry. Contributions to Mineralogy and Petrology, 88, 260-268.

Gonçalves, L., Farina, F., Lana, C., Pedrosa-Soares, A. C., Alkmim, F., Nalini Jr., H. A., (2014). New U-Pb ages and lithochemical attributes of the Ediacaran Rio Doce magmatic arc, Araçuaí confined orogen, southeastern Brazil. Journal of South American Earth Sciences, 52, 129-148.

Gonçalves, L., Alkmim, F., Pedrosa-Soares, A. C., Dussin, I. A., Valeriano, C. M., Lana, C., Tedeschi, M. (2016). Granites of the intracontinental termination of a magmatic arc: an example from the Ediacaran Araçuaí orogen, southeastern Brazil. Gondwana Research, 36, 439-458.

Gradim, C., Roncato, J., Pedrosa-Soares, A. C., Cordani, U., Dussin, I., Alckimin, F. F., Queiroga, G., Jacobsohn, T., Silva, L. C., Babinski, M. (2014). The hot backarc zone of the Araçuaí orogen, Eastern Brazil: from sedimentation to granite generation. Brazilian Journal of Geology. 44, 155-180.

Green, T. H. (1972). Crystallization of calc-alkaline andesite under controlled highpressure hydrous conditions. Contributions to Mineralogy and Petrology, 34, 150166. 
Green T. H. (1992) Experimental phase equilibrium studies of garnet-bearing l-type volcanics and high-level intrusives from Northland, New Zealand. Transactions of the Royal Society of Edinburgh: Earth Sciences, 83, 429-438.

Harrison, T. M., Watson, E. W. (1984). The behavior of apatite during crustal anatexis: equilibrium and kinetic considerations. Geochimica et Cosmochimica Acta, 48, 1467-1477.

Hervé, F., Pankhurst, R. J., Fanning, C. M., Calderón, M. \& Yaxley, G. M. (2007). The South Patagonian batholith: 150 my of granite magmatism on a static plate margin. Lithos, 97, 373-394.

Hirth G., Tullis J. (1992). Dislocation creep regimes in quarzt aggregates. Journ. Struc. Geol., 14:145-149

Janousek V., Farrow, C. M., Erban, V. (2006). Interpretation of whole-rock geochemical data in igneous geochemistry: introducing Geochemical Data Toolkit (GCDkit). Journal of Petrology, 47(6), 1255-1259.

Johnston, A. D., Wyllie, P. J. (1988). Constraints on the origin of Archean trondhjemites based on phase relationships of Nuk gneiss with $\mathrm{H}_{2} \mathrm{O}$ at 15 kbar. Contributions to Mineralogy and Petrology, 100, 35-46.

Karniol, T., Machado, R. (2010). Fluxo tectônico subparalelo ao Cinturão Ribeira no sul do Espírito Santo: análise das estruturas na seção Marechal Floriano-Ibatiba. Revista Brasileira de Geociências. 40(4), 455-467.

Kruhl J. H. (1996). Prism- and basal-plane paralles subgrain boundaries in quartz: a microstructural geothermobarometrer. Journ. Metam. Geol., 14:581-589.

Le Maitre, R. W., Bateman, P., Dudek, A., Keller, J. (1989). A Classification of Igneous rocks and Glossary of Term: Recommendations of the International Union of Geological Sciences Subcommission on the Systematics of Igneous Rocks. Oxford: Blackwell Scientific Publications.

Li, X. P., Zheng, Y. -F., Wu, Y. -B., Chen, F. -K., Gong, B., Li, Y. -L. (2004). Low-T eclogite in the Dabie Terrane of China; petrological and isotopic constraints on fluid activity and radiometric dating. Contributions to Mineralogy and Petrology, 148, $443-470$ 
Liegeois, J.P., Navez, J., Hertogen, J., Black, R., (1998). Contrasting origin of postcollisional high-K calc-alkaline and shoshonitic versus alkaline and peralkaline granitoids. The use of sliding normalization. Lithos, 45 (1-4), 1-28.

Martins V. T. S., Teixeira W., Noce C. M., Pedrosa-Soares A. C. (2004). Sr and Nd characteristics of Brasiliano/Pan-African granitoid plutons of the Araçuaí Orogen, Southeastern Brazil: tectonic Implications. Gondwana Research, 7, 75-89.

Mello, M. F., Machado, R., Bilal, E. (2011). Petrografia e Geoquímica do Complexo Charnockítico de Aimorés: Um de Plutonismo Pós-orogênico do Cinturão Araçuaí/Ribeira. Geologia USP, Série Científica 11(1), 33-57.

Middlemost, E. A. K. (1985) Magmas and magmatic rocks. An introduction to igneous petrology. London: Longman.

Nakamura, N. (1974) Determination of REE, Ba, Fe, Mg, Na and K in carbonaceous and ordinary chondrites. Geochim. Cosmochim. Acta, 38, 757-775.

Miller, C. F., Stoddard, E. F., Bradfish, L. J., Dollase, W. A. (1981). Composition of plutonic muscovite: genetic implications. The Canadian Mineralogist, 19, 25-34.

Moore, N. D., Agar, R. A. (1985). Variations along a batholith: the Arequipa segment of the Coastal Batholith of Peru. In: Pitcher, W., Artherthon, M. P., Cobbing, E. J., Beckinsale, R. D., (eds.). Magmatismo at a Plate Edge: the Peruvian Andes. John Wiley and Sons.

Murphy, J. B. (2007). Igneous Rock Associations 8. Arc Magmatism II. Geochemical and Isotopic Characteristics. Geosciences Canada, 34, 1-29.

Nakamura, N. (1974). Determination of REE, Ba, Fe, Mg, Na, and $\mathrm{K}$ in carbonaceous and ordinary chondrites. Geochimica et Cosmochimica Acta, 38, 757-775.

Nalini Jr., H. A. (1997) Caractérisation des suites magmatiques néoprotérozoïques de la région de Conselheiro Pena et Galiléia (Minas Gerais, Brésil) : Étude géochimique et structurale des suites Galiléia et Urucum et leur relation avec les pegmatites à éléments rares associées. Tese (Doutorado) - École des Mines de Saint Etienne, Saint Etienne, France.

Nalini Jr., H. A., Bilal, E., Paquette, J. L., Pin, C., Machado, R. (2000). Geochronologie $\mathrm{U}-\mathrm{Pb}$ et géochimie isotopique $\mathrm{Sr}-\mathrm{Nd}$ des granitoides 
neoproterozoiques des suites Galileia et Urucum, vallée du Rio Doce, Sud-Est du Brésil. Les Comptes Rendus de l'Académie des sciences , 331, 459-466.

Nalini Jr., H. A., Machado, R., Bilal, E. (2005). Geoquímica e Petrogênese da Suíte Galiléia: Exemplo de Magmatismo Tipo-I Metaluminoso Pré-Colisional Neoproterozóico da Região do Médio Vale do Rio Doce (MG). Revista Brasileira de Geociências, 35, 23-34.

Naney, M. T. (1983). Phase equilibria of rock-forming ferromagnesian silicates in granitic systems. American Journal of Science, 283, 993-1033.

Narduzzi, F., Farina, F., Stevens, G., Lana, C., Nalini Jr., H. A. (2017). Magmatic garnet in the Cordilleran-type Galiléia granitoids of the Araçuaí belt (Brazil): Evidence for crystallization in the lower crust. Lithos, 282-283, 82-97.

Novo, T., Pedrosa-Soares, A. C., Noce, C. M., Alkmim, F. F., Dussin, I. (2010). Rochas charnockíticas do sudeste de Minas Gerais: a raiz granulítica do arco Magmático do Orógeno Araçuaí. Revista Brasileira de Geociencias, 40, 573-592.

Pankhurst R. J., Hole, M. J., Brook, M. (1988). Isotope evidence for the origin of Andean granites. Transactions of the Royal Society of Edinburgh: Earth Sciences, 2-3, 123-133.

Pankhurst, R. J., Weaver, S. D., Hervé, F., Larrondo, P. (1999). Mesozoic-Cenozoic evolution of the North Patagonian Batholith in Aysén, southern Chile. Journal of the Geological Society, 156, 673-694.

Passchier, C. W., Trouw, R. A. J. (2005) Microtectonics. New York: Springer-Verlag. Patiño-Douce, A. E., McCarthy, T. C. (1998). Melting of crustal rocks during continental collision and subduction, in: B. R. Hacker, J. G. Liou, (Eds.), When the continents collide: geodynamics and geochemistry of ultrahigh-pressure rocks: Kluwer Academic Publishers, Dordrecht, pp. 27-55.

Pearce, J. A., Wyman, D. A. (1996). An users guide to basalt discrimination diagrams. Trace Element Geochemistry of Volcanic Rocks: Applications for Massive Sulphide Exploration. Geological Association of Canada, Short Course Notes, 12 , 79-113. 
Pedrosa-Soares, A. C., Noce, C. M. (1998). Where is the suture zone of the Neoproterozoic Araçuaí-West-Congo orogen?. In: International Conference on Basement Tectonics, Extended Abstracts, 14, 35-37. Ouro Preto: IBTA.

Pedrosa-Soares, A. C., Wiedemann-Leonardos, C. M., (2000). Evolution of the Araçuaí Belt and its connection to the Ribeira Belt, Eastern Brazil. In: U. Cordani, E. Milani, A., Thomaz-Filho A. D. A. Campos (Eds.), Tectonic Evolution of South America (265-285). São Paulo: Sociedade Brasileira de Geologia.

Pedrosa-Soares, A. C., Noce, C. M., Vidal, P., Monteiro, R., Leonardos, O. H. (1992). Toward a new tectonic model for the Late Proterzoic Araçuaí (SE Brazil) West Congolian (SW Africa) Belt. Journal of South American Earth Sciences, 6, 3347.

Pedrosa-Soares, A. C., Wiedemann, C. M., Fernandes, M. L. S., Faria, L.F., Ferreira, J. C. H. (1999). Geo-tectonic significance of the Neoproterozoic granitic magmatism in the Araçuaí belt, Eastern Brazil: a model and pertinent questions. Revista Brasileira de Geocienciências, 29, 57-64.

Pedrosa-Soares, A. C., Noce, C. M., Wiedemann, C. M., Pinto, C. P. (2001). The Araçuaí-West Congo orogen in Brazil: An overview of a confined orogen formed during Gondwanland assembly. Precambrian Research, 110, n. 1-4, p.307-323.

Pedrosa-Soares, A. C., Noce, C. M., Alkmim, F. F., Silva, L. C., Babinski, M., Cordani, U., Castañeda, C. (2007). Orógeno Araçuaí: síntese do conhecimento 30 anos após Almeida 1977. Geonomos, 15, 1-16.

Pedrosa-Soares A. C., Alkmin F. F.; Tack L., Noce C. M., Babinski M.; Silva L. C.; Martins Neto M. (2008). Similarities and differences between the Brazilian and African counterparts of the Neoproterozoic Araçuaí West Congo orogen. Geological Society Special Publication, 294, 153-172.

Pedrosa-Soares, A. C., De Campos, C. P., Noce, C. M.; Silva, L. C.; Novo, T., Roncato, J., Medeiros, S., Castañeda, C., Queiroga, G., Dantas, E., Dussin, I., Alkmin, F. (2011). Late Neoproterozoic-Cambrian granitic magmatism in the Araçuaí orogeny (Brazil), the Eastern Brazilian Province and related mineral resources. Geological Society of London, Special Publication, 550, 25-51.

Pitcher, w. S. (1979) The nature, ascent and emplacement of granitic magmas. Journal of the Geological Society, 136, 627-662. 
Shand, S. J. (1949) The study of rocks. New York: The MacMillan Company.

Shervais, J. W., McGee, J. J. (1998). Magma mixing in the petrogenesis alkali suite anorthosites: reverse zoning in plagioclase, 14305,303. Lunar and Planetary Science $X X I X, 1706$.

Schmidt, M. W. (1993). Phase relations and compositions in tonalite as a function of pressure: An experimental study at $650^{\circ}$ C. American Journal of Sciences, 293, 1011-1060.

Schmidt, M. W., Thompson, A. B. (1996). Epidote in calc-alkaline magmas: An experimental study of stability, phase relationships, and the role of epidote in magmatic evolution. American Mineralogist, 81, 462-474

Schmidt, M. W., Poli, S. (2004) Magmatic Epidote. Reviews in Mineralogy and Gechemistry. 56, 399-430.

Siga Jr, O. (1986). A evolução geotectônica da porção nordeste de Minas Gerais, com base em interpretações geocronológicas. Dissertação (Mestrado). São Paulo: Instituto de Geociências - USP.

Signorelli, N. (1993) Mapa geológico da Folha Afonso Cláudio - SF24-V-A-II. Programa de Levantamentos Geológicos Básicos do Brasil, DNPM/CPRM. Escala 1:100000. Brasília: Companhia de Pesquisa de Recursos Minerais/CPRM.

Silva, J. N. (1993) Mapa geológico da Folha Cachoeiro do Itapemirim - SF24-V-AV. Programa de Levantamentos Geológicos Básicos do Brasil, DNPM/CPRM. Escala 1:100000. Brasilia: Companhia de Pesquisa de Recursos Minerais/CPRM.

Silva, M. A., Camozzato, E., Paes, V. J. C., Junqueira, P. A., Ramgrab, G. E. (2004). Folha SF.24-Vitoria. In: C. Schobbenhaus, J. H. Gonçalves, J. O. S Santos, M. B. Abram, R. Leão Neto, G. M. M. Matos, R. M. Vidotti, M. A. B. Ramos, J. D. A. de Jesus, (Eds.), Carta Geológica do Brasil ao Milionésimo, Sistema de Informações Geográficas. Programa Geologia do Brasil. CPRM, Brasília. CD-ROM.

Smith, J. G., Diggles, M. F. (1981). Potassium-argon determinations in the Ketchikan and Prince Rupert quadrangles, southeastern Alaska. U.S. Geological Survey Open-File Report, 78-73.

Söllner, F., Lammerer, B., Weber-Diefenbach, K., Hansen, B. T. (1987) The Brasiliano Orogenesis: Age determinations (Rb-Sr and $\mathrm{U}-\mathrm{Pb})$ in the Costal Montain 
Region of Espírito Santo, Brazil. Zentralblatt für Geologie und Paläontologie, I, 729741.

Söllner F., Lammerer, B., Wiedemann-Leonardos, C. (2000). Dating the Ribeira Mobile Belt of Brazil. Zeitschrift für Angewandte Geologie, 1, 245-255.

Stipp, M., Stünitz, H., Heilbronner, R., Schmid, S. M. (2002). Dynamic recrystallization of quartz: Correlation between natural and experimental conditions. London Special Publications, 200, 171-190.

Streckeisen, A. L. (1967). Classification and nomenclature of igneous rocks. (Final report of an inquiry.) Neues Jahrbuch fur Mineralogie, Abhandlungen, 107, 144-240.

Suárez Rojas, A. M. (2011). Petrologia da Suíte Derribadinha e o tonalito Bom Jesus na região de Governador Valadares (MG). Abordagem estrutural a partir da ASM. Relações com a suíte Galileia. Dissertação (Mestrado). São Paulo: Instituto de Geociências - USP.

Suggate, S. M., Hall, R. (2014). Using detrital garnet compositions to determine provenance: a new compositional database and procedure. Geological Society, London, Special Publications, 386, 373-393.

Tedeschi, M., Novo, T., Pedrosa-Soares, A., Dussin, I., Tassinari, C., Silva, L. C., Gonçalves, L., Alkmim, F., Lana, C., Figueiredo, C., Dantas, E., Medeiros, S., De Campos, C., Corrales, F., Heilbron, M. (2016). The Ediacaran Rio Doce magmatic arc revisited (Araçuaí-Ribeira orogenic system, SE Brazil). Journal of South American Earth Sciences, 68, 167-186

Trompette, R. (1994) Geology of Western Gondwana (2000-500 Ma). Pan-AfricanBrasiliano aggregation of South America and Africa. Rotterdam: A.A. Balkema.

Watson, E. B., Harrison, T. M. (1984). Accessory minerals and geochemical evolution of crustal magmatic systems: a summary and prospectus of experimental approaches. Physics of the Earth and Planetary Interiors, 35, 19-30.

White, A. J. R., Chappel, B. W. (1977). Ultrametamorphism and granitoid genesis. Tectonophysics, 43, 7-22.

Wiedemann, C. M., (1993). The evolution of the Paleozzoic, late- to post-collisional magmatic arc of the coastal mobile belt, in the state of Espírito Santo, eastern Brazil. Anais de Academia Brasileira de Ciências, 65 (Supl. 1): 163-181. 
Wiedemann, C. M., Penha, H. M., Schmidt-Thome, R. (1987). Granitóides do Espírito Santo and Rio de Janeiro States. Revista Brasileira de Geociências , 17 (4): 674-689.

Wiedemann, C. M., Medeiros, S. R., Ludka, I. P., Mendes, J. C., Moura, J. C. (2004). Architecture of Late Orogenic Plutons in the Araçuaí-Ribeira Fold Belt, Southeast Brazil. Gondwana Research , 5 (2): 381-399.

Wilson, M. (1989) Igneous Petrogenesis. A Global Tectonic Approach. London: Unwin Hyman.

Xia, Q. -X., Zheng, Y. -F., Zhou, L.G. (2008). Dehydration and melting during continental collision: constraints from element and isotope geochemistry of low-T/UHP granitic gneiss in the Dabie orogen. Chemical Geology, 247, 3665.

Xia, Q. -X., Zheng, Y. -F., Lu, X. -N., Hu, Z. C., Xu, H. J. (2012). Formation of metamorphic and metamorphosed garnets in the low-T/UHP metagranite during continental collision in the Dabie orogen. Lithos. 136-139, 73-92.

Zen. E, Hammarstrom, J. M. (1984). Magmatic epidote and its petrologic significance. Geology, 12, 515-518

Zheng, Y. -F., Gao, X. -Y., Chen, R. -X., Gao, T.-S. (2011). Zr-in-rutile thermometry of eclogite in the Dabie orogen: constraints on rutile 3 growth during continental subduction-zone metamorphism. Journal of Asian Earth Sciences, 40, 427-451 


\section{Anexo I}

\section{Descrição petrográfica das amostras do Batólito Muniz Freire}

Igor Eduardo Mascarenhas 


\section{PMF 02}

Textura: Lepido-Granoblástica blatoequigranular

Granulação: Matriz granoblástica 0,1-0,5 mm, reliquias ígneas 2,0-3,0 mm

A rocha apresenta uma foliação relativamente homogênea com uma "camada" de 0,5 cm com apenas relíquias ígneas de feldspatos e quartzo deformado e finas camadas de biotita intercaladas e pouco contínuas.

Quartzo é xenomórfico, apresentando ou não extinção ondulante ou em setores, com inclusões de biotita e zircão. Os cristais de quartzo podem estar em mosaicos ou em megacristais alongados segundo a orientação. Plagioclásio apresenta megacristais reliquiares subidiomórficos, mirmequitas, alguma alteração sericitica, geminação lei-da-albita. Alguns poucos cristais são resultado de recristalização e são relativamente menores, com contatos poligonais. Feldspato potássico é xenomórfico, apresenta geminação em grade São poucos os cristais reliquiares ígneos, a maioria dos cristais formando mosaicos de tamanho diminuto. Há um cristal incluso em plagioclásio. Biotita aparece subidiomórfica a xenomórfica, cristais orientados, em maior tamanho nas porções ricas em reliquias ígneas e em menor tamanho nas zonas mais deformadas. Zircão é único acessório, entre cristais ou incluso em quartzo. Muscovita é xenomórfica, presente nas bordas dos cristais de plagioclásio e preenchendo fraturas dos cristais.

Quartzo: 33\%, Plagioclásio: 43\%, feldspato Potássico: 10\%, Biotita: 14\%. Acessórios: Muscovita, Zircão.

\section{PMF 05}

Textura: Lepido-granoblástica

Granulação: Matriz granoblástica de 0,1-0,8mm Relíquias com 2,0-5,0 mm

A rocha apresenta uma foliação onde os cristais de quartzo aparecem bastante alongados e feldspatos estão razoavelmente orientados. Há uma excessiva alteração na rocha, dificultando a identificação de alguns minerais. 
Quartzo é xenomórfico, pode estar em mosaicos ou em megacristais alongados segundo a orientação com extinção ondulante e possivelmente fraturados. Plagioclásio é xenomórfico com megacristais reliquiares com mirmequitas, geminação lei-da-albita, cristais menores formam mosaicos. Feldspato potássico é subidiomórfico a xenomórfico, preservam reliquias ígneas recristalizadas nas bordas e alguns cristais formando mosaicos. Geminação em grade. Alguns cristais apresentam fraturas preenchidas por muscovita. Biotita aparece xenomórfica a subidiomórfica, cristais orientados, associada evidênciando alguma reação com clorita. Muscovita é xenomórfica, substitui plagiocláio em algumas porções e preenche fraturas. Clorita aparece apenas junto da biotita. Como acessório, a rocha apresenta apenas apatita. Há uma breve orientação na lâmina principalmente evidenciada pelas micas,

Quartzo: 39\%, Plagioclásio: 23\%, feldspato Potássico: 34\%, Biotita: 4\%. Acessórios: Muscovita, Clorita.

\section{PMF 06}

Textura: Lepido-granoblástica blastoequigranular

Granulação: Matriz granbolástica de $0,08 \mathrm{~mm}$ a $0,6 \mathrm{~mm}$ e megacristais de 1,5 a $3,6 \mathrm{~mm}$

Quartzo é xenomórfico, pode estar em mosaicos orientados ou em megacristais alongados segundo a orientação com extinção ondulante ou em setores. Plagioclásio é xenomórfico com megacristais reliquiares, forte alteração sericitica, geminação lei-da-albita em poucos cristais, formam mosaicos. Feldspato potássico é subidiomórfico, preservam reliquias ígneas e alguns cristais formando mosaicos. Geminação em grade. Alguns cristais apresentam fraturas. Biotita aparece subidiomórfica, cristais orientados, associada evidênciando alguma reação com clorita. Muscovita é xenomórfica, substitui plagiocláio em algumas porções e preenche fraturas. Clorita aparece apenas junto da biotita em reação. Apatita aparece como acessório.

Quartzo: 66\%, Plagioclásio: 16\%, feldspato Potássico: 15\%, Biotita: $2 \%$. Acessórios: Muscovita, Apatita, Clorita. 


\section{PMF 7A}

Textura: Lepido-Granoblástica com mirmequitas, blasto porfirítica

Granulação: Matriz granoblástica 0,1-0,6 mm, reliquias ígneas 2,0-3,5 mm

Quartzo é xenomórfico e em mosaico, mirmequitas e alguns cristais alongados. Plagioclásio é subidiomórfico, alterado para sericita e muscovita, essa última formando alteração alinhada com a orientação dos cristais. Geminação leida-albilta, por vezes muito fina, ou carlsbad. Feldspato potássico é xenomórfico, preservado em reliquias ígneas ou mosaicos. Contém fraturas que podem estar preenchidas por muscovita. Biotita é subidiomórfica, por vezes em reação com clorita. Clorita é xenomórfica e forma opacos em sua clivagem quando em reação com biotita. Pode estar associada a muscovita. Muscovita é xenomórfica, alterando o plagioclásio ou relacionada as outras micas. Apatita aparece como acessório. Os cristais alongados de quartzo e os cristais de biotita evidenciam a orientação gerada pela deformação que gera a textura lepido-granoblástica.

Quartzo: 54\%, Plagioclásio: 5\%, feldspato Potássico: 33\%, Biotita: $8 \%$. Acessórios: Muscovita, Apatita, Clorita.

\section{PMF 7B}

Textura: Lepido-Granoblástica bandada, blasto porfirítica

Granulação: Matriz granoblástica 0,1-0,4 mm, reliquias ígneas 1,0-2,5 mm

A rocha contém duas bandas, uma escura com maior quantidade de biotita e outra mais clara, composta principalmente de plagioclásio e quartzo e pouca biotita. A rocha ainda apresenta um xenolito quartzo-feldspático com presença de granada. Quartzo é xenomórfico, megacristais com extinção ondulante ou em setores, por vezes orientados. Pode estar em mosaico, principalmente na banda escura onde os cristais estão relativamente diminutos. Plagioclásio é subidiomórfico a xenomórfico, preserva reliquias ígneas, mas pode estar em mosaicos. Geminação é lei-da-albita, mas pode ser carlsbad associado ou sozinha. Há alguma alteração seriticita. Biotita é subidiomórfica, concentrada na banda escura com muscovita, allanita e opacos. Granada é subidiomórfica a xenomórfica e pode ter cristais de clorita inclusos. Clorita aparece apenas nessa situação. Allanita forma agregados 
xenomórficos junto a biotita. Muscovita é xenomórfica e pode aparecer na alteração do feldspato ou associado a biotita. Opacos estão sempre junto a biotita e pode estar formando agregados, sendo provavelmente pirita devido a cor dourada na luz refletida.

Quartzo: 30\%, Plagioclásio: $26 \%$, feldspato Potássico: $7 \%$, Biotita: $29 \%$, Muscovita: 3\% Acessórios: Allanita, Clorita, Opacos.

\section{PMF 9A}

Textura: Lepido-Granoblástica Bandada, blasto porfirítica

Granulação: Matriz granoblástica 0,1-0,7 mm, reliquias ígneas 2,0-4,5 mm

Quartzo é xenomórfico, com extinção ondulada ou em setores, cristais são alongados, podendo ter inclusões de feldspato potássico e biotita, orientados conforme o bandamento. Plagioclásio é xenomórfico, apresentando reliquias ígneas preservadas com extinção zonada e alteração sericitica preferencial na geminação. Aparece em mosaicos em alguns poucos locais. Feldspato potássico é subidiomórfico a xenomórfico com reliquias ígneas preservadas com possíveis inclusões de plagioclásio, quartzo e biotita. Cristais menores em mosaico são comuns. Biotita é subidiomórfica, formando bandas com outros minerais em textura granoblástica e aparece associada a epidoto, titanita, allanita, apatita e opacos. Epidoto aparece como pequenos cristais xenomórficos associados a biotita. Titanita é subidiomórfica associada a biotita e allanita. Allanita aparece como um cristal de $3 \mathrm{~mm}$ de comprimento, zonado, presente na banda de biotita, associado a epidoto e apatita. Apatita está presente nas bandas de biotita. Opacos aparecem sempre nas bandas máficas, alguns cristais contendo uma fina camada de sericita no entorno.

Quartzo: 42\%, Plagioclásio: 16\%, feldspato Potássico: 37\%, Biotita: 5\%. Acessórios: Allanita, Apatita, Epídoto, Titanita, Opacos.

\section{PMF 9B}

Textura: Lepido-granoblástica blastoporfirítica 
Matriz granoblástica 0,1-0,5 mm, reliquias ígneas 2,0-3,0 mm

A rocha é bastante foliada, com laminas de biotita parecendo envolver lentes quartzo-feldspáticas, dando a impressão de uma foliação ondulada. Quartzo é xenomórfico, com megacristais alongados com extinção em setores. Cristais menores foram mosaicos ou são globulares, podendo ocorrer migração de borda. Ocorrem inclusões de feldspato e há evidências de dissolução. Plagioclásio ocorre subidiomórfico a xenomórfico, com geminação lei-da-albita predominante, com carlsbad subordinada. Cristais estão geralmente poligonizados e possuem alteração sericitica e saussuritização. Feldspato potássico preserva cristais reliquiares com bordas irregulares. Ocorre em tamanho diminuto na matriz granoblástica, na maioria das vezes xenomórfico e com contatos poligonizados. Biotita é subidiomórfica, cristais são orientados formando agregados. Allanita, epídoto, clinozoisita, granada aparecem associados a esses agregados de biotita. Allanita ocorre xenomórfica podendo alterar em suas bordas para epídoto e clinozoisita. Epidoto é xenomórfico, alterando a borda da allanita, assim como clinozoisita. Apatita é subidiomórfica e preserva habito circular. Granada ocorre em poucos cristais, associados a biotita, subidiomórfica a xenomórfica.

Quartzo: 29\%, Plagioclásio: 28\%, feldspato Potássico: 27\%, Biotita: 16\%. Acessórios: Allanita, Apatita, Epídoto, Clinozoisita, Granada.

\section{PMF 9C}

Textura: Lepido-granoblástica blastoporfirítica

Granulação: Megacristais de quartzo: 3,0-7,0 mm, Megacristais de feldspato alcalino e plagioclásio: 2,0-4,0 mm, Matriz granoblástica: 0,4-0,6 mm

Quartzo é xenomórfico, megacristais são alongados com extinção em setores, cristais menores formam mosaicos com texturas de dissolução, mirmequitas e migração de borda. Plagioclásio é subidiomórfico, reliquias ígneas preservadas, zonas com cristais em mosaico com mirmequitas, não há uma alteração secundária. Feldspato potássico é xenomórfico, todos os cristais com contatos poligonais, cristais levemente orientados definindo a orientação da lâmina. Biotita é subidiomórfica, muito orientada, formando bandas. Titanita é subidiomórfica a xenomórfica, associada e por vezes inclusa na biotita. Allanita é subidiomórfica, 
zonada, com banda de alteração para clinozoisita, apresenta geminação polissintética. Apatita é subidiomórfica e aparece nas bandas escuras. Opacos tem forma geral de quadrados.

Quartzo: 50\%, Plagioclásio: 28\%, feldspato Potássico: 16\%, Biotita: $6 \%$. Acessórios: Allanita, Apatita, Titanita, Opacos.

\section{PMF 10}

Textura: Lepido-granoblástica blastoporfirítica

Granulação: Megacristais de quartzo: 3,0-7,0 mm, Megacristais de feldspato alcalino: 2,0-4,0 mm, Matriz: 0,4-0,8 mm

Quartzo é xenomórfico, extinção ondulante ou em setores, poucos locais formando mosaicos. Plagioclásio é subidiomórfico, alterado para sericita em alguns locais, geminação lei-da-albita ou geminação ausente, extinção zonada. Feldspato potássico é xenomórfico a subidiomórfico, preservam reliquias ígneas, outros cristais apresentam contatos poligonais. Biotita é subidiomórfico, forma agregados com muscovita, allanita e epidoto. Clorita é xenomórfica. Muscovita é subidiomórfica a xenomórfica, está associada a biotita ou como alteração do plagioclásio. Allanita forma agregados associados a biotita, epido está associado as bordas das allanitas. Apatita é subidiomórfica. Opacos...

Quartzo: 40\%, Plagioclásio: 17\%, feldspato Potássico: 34\%, Biotita: 9\%. Acessórios: Allanita, Apatita, Epidoto, Clorita, Muscovita, Opacos.

\section{PMF 11A}

Lepidogranoblástica blastoporfirítica

Granulação: Matriz granoblástica - 0,1-1,0 mm, Megacristais de plagioclásio: 1,5-2,0 mm, Megacristais de feldspato Potássico - 2,0-5,0 mm

Biotita está bastante orientada, formando porções com alguma continuidade lateral, envolvendo porções com minerais félsicos granoblásticos. Quartzo ocorre xenomórfico, com megacristais alongados e com extinção em setores. Alguns 
cristais menores estão poligonizados com feldspatos. Feldspato potássico ocorre subidiomórfico a xenomórfico, cristais formando mosaicos bem definidos e megacristais com borda recristalizada formando por vezes subgrãos. Plagioclásio é subidiomórfico nas relíquias e xenomórfico na matriz. As relíquias sofrem alguma sericitização nas bordas. Mosaicos não costumam preservar geminação, porém ocorrendo com extinção zonada. Biotita ocorre subidiomórfica a xenomórfica e formam agregados orientados com alguma continuidade lateral. Titanita é xenomórfica e forma agregados de pequenos cristais. Allanita ocorre subidiomórfica e em cristais relativamente grandes, com até $1 \mathrm{~mm}$. Aparece zonada com alteração para epídoto nas bordas. Clorita é xenomórfica e ocorre na clivagem da biotita ou alterando suas bordas. Epidoto é xenomórfico e ocorre alterando as bordas de allanita e plagioclásio. Muscovita é xenomórfico, geralmente produto da alteração do plagioclásio.

Quartzo: 28\%, Plagioclásio: 25\%, feldspato Potássico, 39\%, Biotita: 8\%. Acessórios: Allanita, Apatita, Epídoto, Titanita, Opacos.

\section{PMF 11B}

Textura: Equigranular

Granulação: 0,2-0,7 mm

Quartzo é xenomórfico e pode apresentar extinção ondulada. Feldspato potássico é xenomórfico, apresenta pertitas. Plagioclásio é xenomórfico e apresenta contatos entre borda e núcleo (rapakivi?) Biotita é xenomórfica. Granada é idiomórfica. Opacos são quadrados e de cor dourada em luz refletida, possivelmente pirita. Algumas fraturas na rocha estão associadas a opacos.

Quartzo: 42\%, plagioclásio: 16\%, feldspato potássico: $37 \%$, biotita: $5 \%$. Acessórios: allanita, apatita, epídoto, titanita, opacos.

\section{PMF 12}

Textura: Nemato-lepido-granoblástica bandada, blasto porfirítica. 
Granulação: Megacristais de quartzo: 3,0-7,0 mm, Megacristais de feldspato potássico e plagioclásio: 2,0-3,0 mm, Matriz granoblástica: 0,4-0,6 mm

Quartzo é xenomórfico, megacristais alongados com extinção em setores, regiões de mosaicos com dissolução e migração de borda. Plagioclásio é subidiomórfica, pouca alteração sericitica, megacristais fraturados, geminação leida-albita, alguns cristais sem geminação com extinção zonada. Feldspato potássico é xenomórfico, forma mosaicos, megacristais com bordas alteradas formando cristais independentes, geminação em grade, possivelmente conter plagioclásio incluso. Biotita é subidiomórfica, cristais orientados, associada a hornblenda, clorita, muscovita e acessórios. Clorita é xenomórfica, associada a biotita provavelmente em reação com esta, e opacos na clivagem. Epidoto é xenomórfica, associado a hornblenda e produto de alteração das bordas dos cristais de allanita. Allanita é subidiomórfica, zonada, alterada nas bordas. Titanita é subidiomórfica, associada a biotita, cristais por vezes alinhados como em veios. Hornblenda é subidiomórfica, associada a epidoto e biotita. Muscovita é xenomórfica e associada a biotita. Opacos tem forma octagonais, possívelmente pirita.

Quartzo: 46\%, Plagioclásio: 36\%, feldspato Potássico: 8\%, Biotita: $10 \%$. Acessórios: Allanita, Epidoto, Clorita, Muscovita, Opacos, Hornblenda, Titanita.

\section{PMF 14A}

Textura: Lepido-granoblástica blastoporfirítica

Granulação: Megacristais de quartzo: 2,0-5,0 mm. Megacristais de plagioclásio: 1,0-1,5 mm Matriz granoblástica: 0,4-0,6 mm

Quartzo é xenomórfico, granoblástico, com contatos poligonais ou megacristais alongados com extinção ondulante ou em setores. Plagioclásio é subidiomórfico, por vezes formando mosaicos, saussuritização, geminação lei-daalbita fina. Feldspato potássico é xenomórfico, sempre formando mosaicos. Biotita é subidiomórfica, orientada, associada com epidoto, titanita, allanita, clorita e biotita. Epidoto é subidiomórfico a xenomórfico, associado a biotita e titanita, produto de alteração do plagioclásio e das bordas da allanita. Titanita é subidiomórfica a xenomórfica, associada a biotita e epidoto. Clinozoisita está presente na alteração 
do plagioclásio. Biotita verde aparece entre outros cristais de biotita. Allanita é xenomórfica e com alteração na borda dos cristais. Muscovita está presente na alteração do plagioclásio e preenchendo fraturas. Clorita está intercalada a biotita formando alguma reação

Quartzo: 34\%, Plagioclásio: 43\%, feldspato Potássico: 9\%, Biotita: 13\%. Acessórios: Allanita, Epidoto, Clinozoisita, Clorita, Muscovita, Opacos.

\section{PMF 14B}

Textura: equigranular

Granulação: 0,2 a 0,6 mm

A rocha tem uma orientação visível a olho nu e observável pela leve orientação dos cristais de feldspato potássico. Quartzo é xenomórfico e goticular com extinção ondulante. Contatos são interlobados e pode ocorrer migração de borda. Plagioclásio ocorre em menor quantidade, alguns com borda e núcleo distinto, geminação lei da albita é incomum, predomina extinção zonada forte com núcleo rico em $\mathrm{Ca}$, inclusive alterando preferencialmente neste. Pode sofrer saussuritização. Feldspato potássico tem contatos interlobados, cristais levemente orientados. Biotita ocorre orientada segundo a foliação e associada a clorita, que por sua vez é xenomórfica e parece alterar a biotita. Muscovita ocorre substituindo plagioclásio e preenchendo fraturas. Opacos podem ocorrer na clivagem da clorita ou formando poligonos de forma aproximadamente octogonais. Epidoto ocorre alterando plagioclásio.

Quartzo: 25\%, Plagioclásio: 8\%, feldspato Potássico: 65\%, Biotita: 2\%. Acessórios: Clorita, Muscovita, Opacos, Epídoto.

PMF 14C

Textura: Blastoequigranular

Granulação: 0,2-0,5 mm

Quartzo é xenomórfico e possui extinção ondulada. Feldspato potássico ocorre subidiomórfico a xenomórfico, cristais orientados e alguns contatos são 
poligonais. Plagioclásio não possui geminação, é xenomórfico e os cristais estão levemente zonados. Biotita aparece subidiomórfica, orientada segundo a foliação, altera para clorita. Clorita ocorre associada a opacos e em reação com a biotita. Muscovita está presente junto a biotita. Opacos ocorre juntos de cristais de biotita e na clivagem da clorita. Allanita é zonada e subidiomórfica.

Quartzo: 41\%, Plagioclásio: 5\%, feldspato Potássico: 50\%, Biotita: 3\%. Acessórios: Allanita, Clorita, Muscovita, Opacos.

\section{PMF 18}

Textura: Lepidogranoblástica blastoporfirítica

Granulação: Megacristais de 2,3-6,9 mm, matriz granoblástico de 0,1-1,0 mm

Quartzo ocorre em megacristais xenomórficos com extinção em setores, inclusões de feldspato potássico e plagicolásio. Cristais menores são xenomórficos e formam mosaicos com alguma evidência de migração de borda. Feldspato potássico preserva cristais reliquiares subidiomórficos a xenomórficos e forma pertitas. Plagioclásio são relíquiares, subidiomórficos, tem mirmequitas e extinção zonada. Biotita ocorre como cristais subidiomórficos, orientados e alterando para clorita. Allanita ocorre associada a biotita em aglomerados que podem ter germinação simples. Clorita ocorre exclusivamente alterando a biotita em alguma reação. Apatita é subidiomórfica e aparece junto da biotita e allanita.

Quartzo: 28\%, Plagioclásio: 30\%, feldspato Potássico: 37\%, Biotita: $5 \%$. Acessórios: Allanita, Clorita, Apatita, Zircão.

\section{PMF 24}

Textura: Lepidogranoblástico blasporfirítica

Granulação: Cristais reliquiares: 1,0-2,5 mm, matriz granoblástica 0,5-1,0 mm

Quartzo é xenomórfico e ocorre com habito goticular e alguma extinção ondulante. Feldspato potássico é xenomórfico, alguns locais granoblástico, outros com cristais reliquiares com inclusões de plagioclásio e pertitas. Plagioclásio ocorre 
subidiomórfico e levemente alterado para sericita. Biotita é subidiomórfica, orientada, formando bandas com allanita e muscovita. Allanita forma agregados com epidoto e biotita.

Quartzo: 4\%, Plagioclásio: 31\%, feldspato Potássico: 57\%, Biotita: $8 \%$. Acessórios: Allanita, Epidoto, Apatita. 


\section{Anexo II}

\section{Análises químicas de granada, epídoto e plagioclásio do Batólito Muniz Freire}

Igor Eduardo Mascarenhas 


\section{GRANADA}

Amostra-

Cristal PMF-9B-1

\begin{tabular}{|c|c|c|c|c|c|c|c|c|c|c|c|c|c|c|c|c|c|c|c|c|}
\hline Local & $b$ & $b$ & $b$ & b & C & C & C & C & C & C & C & C & C & C & C & C & $b$ & $b$ & $b$ & b \\
\hline anto & 1 & 2 & 3 & 4 & 5 & 6 & 7 & 8 & 9 & 10 & 11 & 12 & 13 & 14 & 15 & 16 & 17 & 18 & 19 & 20 \\
\hline
\end{tabular}

\begin{tabular}{l|lllllllllllllllllllllllll}
$\mathrm{SiO}_{2}$ & 37,01 & 37,15 & 37,45 & 37,25 & 36,91 & 37,49 & 37,49 & 37,44 & 37,30 & 37,52 & 37,37 & 37,26 & 37,27 & 37,40 & 37,29 & 37,28 & 37,00 & 37,06 & 37,39 & 37,11
\end{tabular}

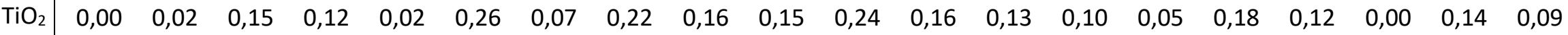
$\begin{array}{lllllllllllllllllllllllll}\mathrm{Al}_{2} \mathrm{O}_{3} & 20,24 & 20,57 & 20,70 & 20,64 & 20,04 & 20,70 & 20,86 & 20,71 & 20,96 & 20,85 & 20,88 & 20,69 & 20,77 & 20,81 & 21,08 & 20,69 & 20,76 & 20,37 & 20,60 & 20,74\end{array}$ $\begin{array}{lllllllllllllllllllllllllllllll}\text { FeOT } & 19,59 & 20,28 & 18,51 & 18,47 & 19,37 & 18,30 & 18,64 & 18,28 & 17,52 & 17,33 & 17,49 & 17,71 & 17,86 & 17,49 & 18,03 & 17,89 & 17,97 & 19,75 & 18,24 & 19,43\end{array}$

$\begin{array}{lllllllllllllllllllllllllll}M n O & 11,32 & 10,95 & 10,46 & 10,31 & 10,47 & 10,05 & 10,13 & 9,98 & 10,59 & 10,92 & 10,85 & 10,64 & 10,72 & 10,59 & 10,53 & 10,84 & 10,90 & 11,17 & 10,93 & 10,88\end{array}$

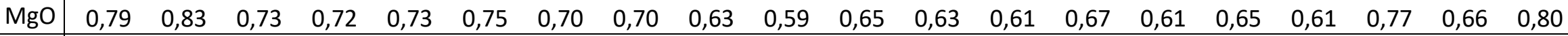
\begin{tabular}{l|lllllllllllllllllllll} 
Total & 98,10 & 99,08 & 99,05 & 98,34 & 98,46 & 99,34 & 99,24 & 99,16 & 99,05 & 99,07 & 99,18 & 98,69 & 98,97 & 98,85 & 98,95 & 98,87 & 98,74 & 98,36 & 98,84 & 99,27
\end{tabular}

\begin{tabular}{l|llllllllllllllllllll} 
Almandine & 43,20 & 44,45 & 40,75 & 41,35 & 40,80 & 39,73 & 41,20 & 39,90 & 38,98 & 38,51 & 38,71 & 39,11 & 39,33 & 38,74 & 40,81 & 39,40 & 39,65 & 43,66 & 40,23 & 42,43
\end{tabular}

$\begin{array}{lllllllllllllllllllll}\text { Andradite } & 1,16 & 1,24 & 0,49 & 0,05 & 3,11 & 0,89 & 0,34 & 0,77 & 0,18 & 0,00 & 0,22 & 0,50 & 0,64 & 0,28 & 0,00 & 0,58 & 0,84 & 0,99 & 0,47 & 1,25\end{array}$

\begin{tabular}{l|lllllllllllllllllllllllll} 
Grossular & 25,91 & 25,76 & 31,73 & 31,74 & 28,84 & 33,32 & 32,39 & 33,58 & 34,17 & 33,99 & 33,56 & 33,30 & 32,94 & 33,96 & 32,75 & 32,41 & 32,12 & 26,11 & 31,24 & 28,26
\end{tabular}

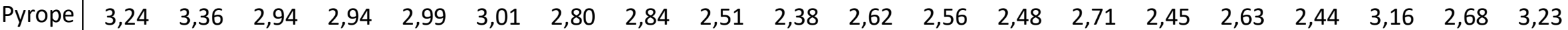

\begin{tabular}{l|llllllllllllllllllllllllllll} 
Spessartine & 26,48 & 25,19 & 24,09 & 23,92 & 24,25 & 23,05 & 23,16 & 22,91 & 24,16 & 25,08 & 24,83 & 24,51 & 24,55 & 24,31 & 24,00 & 24,95 & 24,95 & 25,99 & 25,27 & 24,83
\end{tabular}

$\begin{array}{llllllllllllllllllllll}\text { Uvarovite } & 0,01 & 0,00 & 0,00 & 0,00 & 0,01 & 0,00 & 0,10 & 0,00 & 0,00 & 0,03 & 0,05 & 0,00 & 0,06 & 0,00 & 0,00 & 0,02 & 0,00 & 0,09 & 0,11 & 0,00\end{array}$ 


\section{GRANADA}

Amostra-

Cristal PMF-9B-2

\begin{tabular}{|c|c|c|c|c|c|c|c|c|c|c|c|c|c|c|c|c|c|}
\hline Local & $b$ & $b$ & $b$ & $b$ & C & c & C & b & $b$ & $b$ & b & $b$ & b & $b$ & b & b & $b$ \\
\hline Ponto & 1 & 2 & 3 & 4 & 5 & 6 & 7 & 8 & 9 & 10 & 11 & 12 & 13 & 14 & 15 & 16 & 17 \\
\hline $\mathrm{SiO}_{2}$ & 37,18 & 37,21 & 37,38 & 37,24 & 37,1 & 37,24 & 37,02 & 37,18 & 37,4 & 37,28 & 37,36 & 36,95 & 37,29 & 37,29 & 37,04 & 37,2 & 37,21 \\
\hline $\mathrm{TiO}_{2}$ & 0,0559 & 0 & 0,0809 & 0,0212 & 0,0721 & 0,1185 & 0 & 0,0398 & 0,114 & 0,1256 & 0,0707 & 0,0524 & 0,0756 & 0,0432 & 0,0862 & 0,0282 & 0,104 \\
\hline $\mathrm{Al}_{2} \mathrm{O}_{3}$ & 20,35 & 20,56 & 20,57 & 20,41 & 20,55 & 20,49 & 20,55 & 20,56 & 20,64 & 20,48 & 20,61 & 20,35 & 20,6 & 20,55 & 20,33 & 20,48 & 20,74 \\
\hline $\mathrm{FeOT}$ & 18,89 & 18,42 & 17,68 & 18,9 & 18,25 & 18,2 & 18,48 & 18,32 & 18,92 & 18,12 & 18,6 & 19,53 & 19,5 & 19,44 & 19,29 & 19,07 & 18,76 \\
\hline $\mathrm{MnO}$ & 10,77 & 10,85 & 11,01 & 10,83 & 10,96 & 10,97 & 10,9 & 10,96 & 10,56 & 10,67 & 10,38 & 11,12 & 10,69 & 10,79 & 10,59 & 10,81 & 10,9 \\
\hline MgO & 0,7374 & 0,7141 & 0,7012 & 0,6886 & 0,6422 & 0,6355 & 0,6408 & 0,6825 & 0,7359 & 0,7237 & 0,7003 & 0,7256 & 0,7611 & 0,7411 & 0,7653 & 0,7071 & 0,7385 \\
\hline Total & 98,32 & 98,47 & 98,27 & 98,56 & 98,51 & 98,50 & 98,42 & 98,59 & 99,21 & 98,26 & 98,56 & 98,62 & 99,01 & 98,96 & 98,43 & 98,69 & 98,69 \\
\hline Almandine & 41,43 & 40,65 & 39,52 & 41,33 & 40,13 & 40,08 & 40,67 & 40,25 & 41,25 & 40,16 & 41,31 & 42,41 & 42,85 & 42,59 & 41,99 & 41,74 & 41,97 \\
\hline Andradite & 1,07 & 0,77 & 0,00 & 1,15 & 0,96 & 0,72 & 1,09 & 0,94 & 1,00 & 0,40 & 0,30 & 1,79 & 0,88 & 1,03 & 1,55 & 1,16 & 0,13 \\
\hline Grossular & 29,39 & 30,58 & 31,97 & 29,58 & 30,99 & 31,14 & 30,50 & 30,74 & 30,51 & 31,61 & 31,47 & 27,14 & 28,54 & 28,47 & 28,77 & 29,23 & 29,75 \\
\hline Pyrope & 3,02 & 2,91 & 2,87 & 2,81 & 2,61 & 2,60 & 2,60 & 2,77 & 2,98 & 2,97 & 2,86 & 2,95 & 3,09 & 3,01 & 3,12 & 2,88 & 3,00 \\
\hline Spessartine & 25,08 & 25,09 & 25,64 & 25,13 & 25,31 & 25,47 & 25,13 & 25,30 & 24,27 & 24,86 & 24,06 & 25,71 & 24,64 & 24,90 & 24,57 & 25,00 & 25,15 \\
\hline Uvarovite & 0,00 & 0,00 & 0,00 & 0,00 & 0,00 & 0,00 & 0,00 & 0,00 & 0,00 & 0,00 & 0,00 & 0,00 & 0,00 & 0,00 & 0,00 & 0,00 & 0,00 \\
\hline
\end{tabular}




\section{EPÍDOTO}

Amostra-

Cristal PMF-14A-1

PMF-14A-2

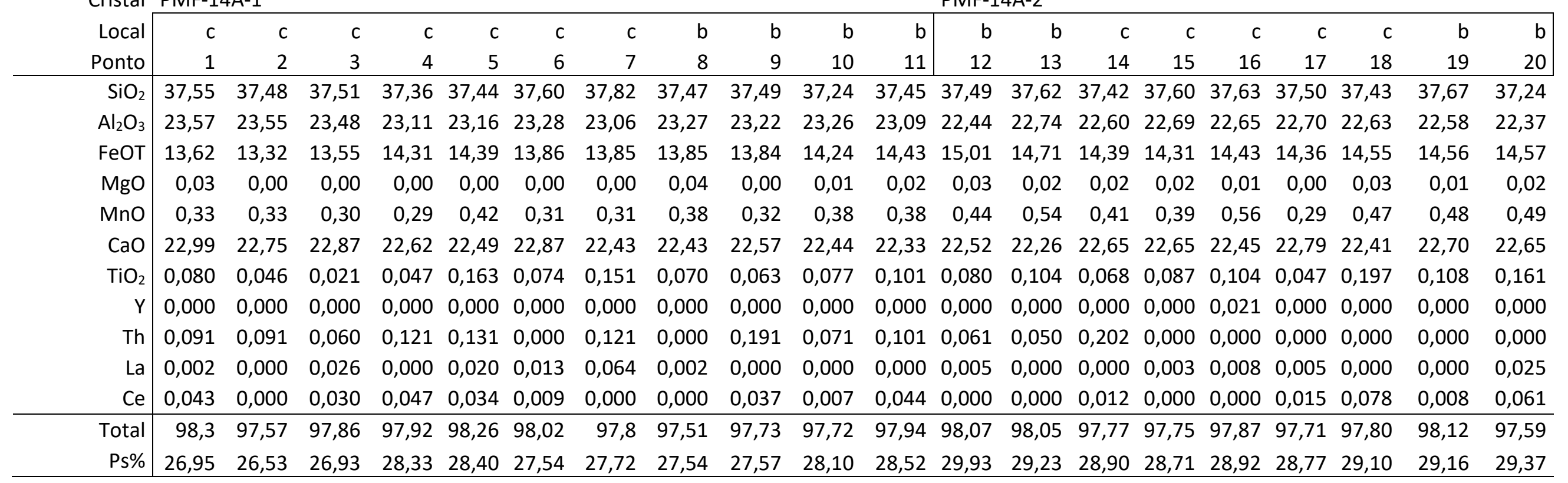




\section{EPÍDOTO}

Amostra-

Cristal PMF-14A-3

PMF-14A-4

\begin{tabular}{r|rrrrrrrrrrrr|rrrrrrrrrr} 
Local & $\mathrm{b}$ & $\mathrm{b}$ & $\mathrm{c}$ & $\mathrm{c}$ & $\mathrm{c}$ & $\mathrm{c}$ & $\mathrm{c}$ & $\mathrm{c}$ & $\mathrm{b}$ & $\mathrm{b}$ & $\mathrm{b}$ & $\mathrm{b}$ & $\mathrm{c}$ & $\mathrm{c}$ & $\mathrm{c}$ & $\mathrm{c}$ & $\mathrm{c}$ & $\mathrm{c}$ & $\mathrm{c}$ & $\mathrm{c}$ \\
Ponto & 21 & 22 & 23 & 24 & 25 & 26 & 27 & 28 & 29 & 30 & 31 & 32 & 33 & 34 & 35 & 36 & 37 & 38 & 39 & 40 \\
\hline $\mathrm{SiO}_{2}$ & 37,48 & 37,64 & 37,64 & 37,49 & 37,42 & 37,37 & 37,55 & 37,90 & 37,46 & 37,61 & 37,41 & 37,39 & 37,46 & 37,52 & 37,39 & 37,46 & 37,45 & 37,36 & 37,71 & 37,55 \\
$\mathrm{Al}_{2} \mathrm{O}_{3}$ & 23,38 & 23,41 & 23,31 & 23,04 & 22,49 & 22,49 & 22,57 & 22,61 & 22,52 & 22,97 & 22,80 & 22,86 & 22,88 & 22,87 & 22,93 & 22,92 & 23,10 & 23,11 & 23,25 & 23,10 \\
$\mathrm{FeOT}$ & 13,60 & 13,82 & 13,73 & 14,09 & 14,95 & 14,82 & 14,98 & 14,54 & 14,82 & 14,34 & 14,11 & 14,54 & 14,13 & 14,00 & 14,50 & 14,39 & 14,15 & 14,26 & 13,97 & 14,22 \\
$\mathrm{MgO}$ & 0,01 & 0,05 & 0,02 & 0,04 & 0,01 & 0,02 & 0,05 & 0,00 & 0,01 & 0,01 & 0,01 & 0,03 & 0,01 & 0,01 & 0,02 & 0,00 & 0,03 & 0,03 & 0,01 & 0,00 \\
$\mathrm{MnO}$ & 0,34 & 0,71 & 0,37 & 0,52 & 0,39 & 0,40 & 0,43 & 0,46 & 0,45 & 0,45 & 0,36 & 0,38 & 0,37 & 0,41 & 0,37 & 0,39 & 0,40 & 0,35 & 0,27 & 0,27 \\
$\mathrm{CaO}$ & 22,61 & 22,03 & 22,73 & 22,73 & 22,69 & 22,65 & 22,66 & 22,46 & 22,71 & 22,52 & 22,34 & 22,27 & 22,78 & 22,23 & 22,56 & 22,71 & 22,50 & 22,83 & 22,94 & 22,52 \\
$\mathrm{TiO}_{2}$ & 0,058 & 0,109 & 0,046 & 0,246 & 0,083 & 0,019 & 0,020 & 0,045 & 0,127 & 0,100 & 0,111 & 0,127 & 0,054 & 0,106 & 0,147 & 0,118 & 0,093 & 0,063 & 0,079 & 0,079 \\
$\mathrm{Y}$ & 0,045 & 0,026 & 0,031 & 0,000 & 0,000 & 0,000 & 0,000 & 0,000 & 0,000 & 0,000 & 0,000 & 0,000 & 0,000 & 0,000 & 0,000 & 0,000 & 0,000 & 0,000 & 0,000 & 0,000 \\
$\mathrm{Th}$ & 0,172 & 0,000 & 0,000 & 0,000 & 0,091 & 0,000 & 0,000 & 0,020 & 0,000 & 0,051 & 0,293 & 0,152 & 0,172 & 0,202 & 0,040 & 0,000 & 0,000 & 0,000 & 0,040 & 0,131 \\
$\mathrm{La}$ & 0,000 & 0,073 & 0,000 & 0,031 & 0,011 & 0,000 & 0,039 & 0,000 & 0,000 & 0,012 & 0,008 & 0,059 & 0,000 & 0,014 & 0,027 & 0,000 & 0,000 & 0,016 & 0,000 & 0,025 \\
$\mathrm{Ce}$ & 0,000 & 0,000 & 0,000 & 0,000 & 0,010 & 0,000 & 0,033 & 0,000 & 0,000 & 0,007 & 0,000 & 0,000 & 0,000 & 0,048 & 0,010 & 0,023 & 0,000 & 0,000 & 0,000 & 0,000 \\
\hline $\mathrm{Total}$ & 97,7 & 97,87 & 97,88 & 98,19 & 98,16 & 97,76 & 98,32 & 98,04 & 98,09 & 98,07 & 97,45 & 97,8 & 97,85 & 97,41 & 97,99 & 98 & 97,73 & 98,02 & 98,27 & 97,91 \\
$\mathrm{Ps} \%$ & 27,08 & 27,38 & 27,33 & 28,08 & 29,80 & 29,61 & 29,76 & 29,11 & 29,59 & 28,50 & 28,32 & 28,88 & 28,28 & 28,10 & 28,76 & 28,62 & 28,12 & 28,26 & 27,73 & 28,21 \\
\hline
\end{tabular}




\section{EPÍDOTO}

Amostra-

Cristal PMF-14A-4 PMF-14A-5

\begin{tabular}{r|rr|rrrrrrrrr} 
Local & $\mathrm{b}$ & $\mathrm{b}$ & $\mathrm{c}$ & $\mathrm{c}$ & $\mathrm{c}$ & $\mathrm{c}$ & $\mathrm{c}$ & $\mathrm{c}$ & $\mathrm{b}$ & $\mathrm{b}$ & $\mathrm{b}$ \\
Ponto & 41 & 42 & 44 & 45 & 46 & 47 & 48 & 49 & 50 & 51 & 52 \\
\hline $\mathrm{SiO}_{2}$ & 37,43 & 37,17 & 37,46 & 37,62 & 37,51 & 37,46 & 37,40 & 37,37 & 37,80 & 37,59 & 37,46 \\
$\mathrm{Al}_{2} \mathrm{O}_{3}$ & 22,90 & 23,08 & 23,27 & 23,33 & 23,12 & 23,39 & 23,10 & 23,04 & 23,48 & 23,18 & 23,24 \\
$\mathrm{FeOT}$ & 14,07 & 14,08 & 13,74 & 13,77 & 13,46 & 13,61 & 13,98 & 14,00 & 13,57 & 13,30 & 13,62 \\
$\mathrm{MgO}$ & 0,01 & 0,01 & 0,02 & 0,04 & 0,02 & 0,00 & 0,04 & 0,00 & 0,02 & 0,04 & 0,00 \\
$\mathrm{MnO}$ & 0,30 & 0,33 & 0,32 & 0,32 & 0,31 & 0,28 & 0,40 & 0,30 & 0,39 & 0,38 & 0,34 \\
$\mathrm{CaO}$ & 22,54 & 22,49 & 22,65 & 22,74 & 22,66 & 22,35 & 22,75 & 22,50 & 22,42 & 22,54 & 22,61 \\
$\mathrm{TiO}_{2}$ & 0,076 & 0,073 & 0,049 & 0,020 & 0,141 & 0,136 & 0,171 & 0,162 & 0,102 & 0,039 & 0,124 \\
$\mathrm{Y}$ & 0,000 & 0,000 & 0,000 & 0,000 & 0,000 & 0,000 & 0,000 & 0,000 & 0,000 & 0,000 & 0,000 \\
$\mathrm{Th}$ & 0,172 & 0,182 & 0,030 & 0,020 & 0,202 & 0,020 & 0,030 & 0,121 & 0,000 & 0,000 & 0,041 \\
$\mathrm{La}$ & 0,047 & 0,000 & 0,000 & 0,000 & 0,000 & 0,022 & 0,030 & 0,000 & 0,000 & 0,000 & 0,062 \\
$\mathrm{Ce}$ & 0,020 & 0,016 & 0,002 & 0,004 & 0,001 & 0,046 & 0,007 & 0,000 & 0,000 & 0,056 & 0,005 \\
\hline $\mathrm{Total}$ & 97,7 & 97,87 & 97,88 & 98,19 & 98,16 & 97,76 & 98,32 & 98,04 & 98,09 & 98,07 & 97,45 \\
$\mathrm{Ps} \%$ & 27,08 & 27,38 & 27,33 & 28,08 & 29,80 & 29,61 & 29,76 & 29,11 & 29,59 & 28,50 & 28,32 \\
\hline
\end{tabular}




\section{PLAGIOCLÁSIO}

Amostra-

Cristal STX-265B-1

STX-265B-2 STX-265B-3 STX-265B-5 STX-265B-5

\begin{tabular}{|c|c|c|c|c|c|c|c|c|c|c|c|c|c|c|c|c|c|c|c|c|}
\hline & & & & & & & & & & & & & & & & & & & & \\
\hline Local & $b$ & $b$ & C & c & C & C & C & $b$ & $b$ & C & $b$ & C & $b$ & C & $b$ & C & $b$ & c & c & $b$ \\
\hline Ponto & 1 & 2 & 3 & 4 & 5 & 6 & 7 & 8 & 9 & 10 & 11 & 12 & 13 & 14 & 15 & 16 & 17 & 18 & 19 & 20 \\
\hline s (\%) & & & & & & & & & & & & & & & & & & & & \\
\hline $\mathrm{SiO}_{2}$ & 62,41 & 62,49 & 62,19 & 61,73 & 61,80 & 61,89 & 61,70 & 62,41 & 62,68 & 62,84 & 64,97 & 68,42 & 62,45 & 62,59 & 62,40 & 62,45 & 62,87 & 63,13 & 62,69 & 62,54 \\
\hline $\mathrm{Al}_{2} \mathrm{O}_{3}$ & 24,66 & 24,59 & 24,89 & 25,00 & 25,12 & 24,96 & 24,84 & 24,62 & 24,42 & 24,35 & 22,87 & 20,44 & 24,50 & 24,57 & 24,46 & 24,35 & 24,10 & 24,12 & 24,02 & 24,41 \\
\hline $\mathrm{Fe}_{2} \mathrm{O}_{3}$ & 0,04 & 0,09 & 0,03 & 0,05 & 0,06 & 0,11 & 0,03 & 0,03 & 0,01 & 0,09 & 0,03 & 0,07 & 0,07 & 0,00 & 0,05 & 0,08 & 0,06 & 0,08 & 0,09 & 0,09 \\
\hline $\mathrm{MnO}$ & 0,00 & 0,00 & 0,01 & 0,00 & 0,00 & 0,00 & 0,00 & 0,01 & 0,00 & 0,01 & 0,00 & 0,02 & 0,00 & 0,02 & 0,00 & 0,00 & 0,00 & 0,01 & 0,00 & 0,00 \\
\hline $\mathrm{CaO}$ & 5,13 & 5,03 & 5,32 & 5,52 & 5,77 & 5,59 & 5,54 & 5,02 & 4,97 & 4,86 & 3,18 & 0,40 & 5,06 & 5,09 & 4,98 & 4,96 & 4,74 & 4,56 & 4,59 & 5,00 \\
\hline $\mathrm{K}_{2} \mathrm{O}$ & 0,15 & 0,14 & 0,24 & 0,27 & 0,23 & 0,27 & 0,27 & 0,19 & 0,19 & 0,22 & 0,15 & 0,14 & 0,14 & 0,10 & 0,12 & 0,32 & 0,22 & 0,29 & 0,30 & 0,30 \\
\hline $\mathrm{SrO}$ & 0,09 & 0,07 & 0,06 & 0,04 & 0,07 & 0,01 & 0,06 & 0,03 & 0,08 & 0,05 & 0,03 & 0,01 & 0,09 & 0,06 & 0,04 & 0,07 & 0,04 & 0,07 & 0,04 & 0,04 \\
\hline $\mathrm{TiO}_{2}$ & 0,03 & 0,00 & 0,00 & 0,01 & 0,00 & 0,00 & 0,00 & 0,02 & 0,04 & 0,00 & 0,03 & 0,02 & 0,00 & 0,00 & 0,00 & 0,00 & 0,00 & 0,00 & 0,00 & 0,00 \\
\hline $\mathrm{BaO}$ & 0,01 & 0,03 & 0,04 & 0,00 & 0,07 & 0,00 & 0,00 & 0,04 & 0,03 & 0,08 & 0,02 & 0,00 & 0,01 & 0,00 & 0,02 & 0,05 & 0,05 & 0,00 & 0,02 & 0,00 \\
\hline $\mathrm{Na}_{2} \mathrm{O}$ & 8,50 & 8,55 & 8,32 & 8,24 & 8,12 & 8,18 & 8,22 & 8,64 & 8,48 & 8,69 & 9,72 & 11,23 & 8,67 & 8,60 & 8,69 & 8,57 & 8,69 & 8,75 & 8,67 & 8,54 \\
\hline $\mathrm{MgO}$ & 0,00 & 0,00 & 0,00 & 0,00 & 0,00 & 0,00 & 0,00 & 0,00 & 0,00 & 0,00 & 0,00 & 0,00 & 0,00 & 0,00 & 0,00 & 0,00 & 0,00 & 0,00 & 0,00 & 0,00 \\
\hline Total & 101,03 & 100,99 & 101,09 & 100,86 & 101,24 & 101,01 & 100,66 & 101,02 & 100,89 & 101,19 & 101,00 & 100,75 & 100,99 & 101,03 & 100,75 & 100,85 & 100,77 & 101,02 & 100,42 & 100,92 \\
\hline
\end{tabular}




\begin{tabular}{|c|c|c|c|c|c|c|c|c|c|c|c|c|c|c|}
\hline \multicolumn{15}{|l|}{$\begin{array}{c}\text { PLAGIOCLÁS } \\
\text { Amostra- }\end{array}$} \\
\hline Local & $b$ & $b$ & C & C & C & C & $b$ & $b$ & $b$ & C & $b$ & C & $b$ & C \\
\hline Ponto & 1 & 2 & 3 & 4 & 5 & 6 & 7 & 8 & 9 & 10 & 11 & 12 & 13 & 14 \\
\hline \multicolumn{15}{|l|}{ Óxidos (\%) } \\
\hline $\mathrm{SiO}_{2}$ & 62,20 & 61,17 & 61,36 & 61,37 & 61,38 & 61,86 & 61,58 & 61,33 & 60,49 & 60,97 & 67,06 & 61,50 & 61,20 & 61,00 \\
\hline $\mathrm{Al}_{2} \mathrm{O}_{3}$ & 24,42 & 25,07 & 25,06 & 24,89 & 24,72 & 24,76 & 24,90 & 24,71 & 24,87 & 24,89 & 20,70 & 24,80 & 24,86 & 25,08 \\
\hline $\mathrm{Fe}_{2} \mathrm{O}_{3}$ & 0,09 & 0,07 & 0,10 & 0,08 & 0,10 & 0,06 & 0,05 & 0,06 & 0,08 & 0,08 & 0,05 & 0,04 & 0,04 & 0,05 \\
\hline $\mathrm{MnO}$ & 0,00 & 0,01 & 0,02 & 0,00 & 0,00 & 0,01 & 0,00 & 0,00 & 0,00 & 0,00 & 0,01 & 0,00 & 0,00 & 0,00 \\
\hline $\mathrm{CaO}$ & 5,02 & 5,75 & 5,81 & 5,67 & 5,54 & 5,63 & 5,56 & 5,29 & 5,58 & 5,55 & 0,96 & 5,40 & 5,40 & 5,86 \\
\hline $\mathrm{K}_{2} \mathrm{O}$ & 0,26 & 0,27 & 0,30 & 0,38 & 0,36 & 0,37 & 0,39 & 0,38 & 0,28 & 0,27 & 0,08 & 0,14 & 0,21 & 0,22 \\
\hline $\mathrm{SrO}$ & 0,10 & 0,08 & 0,08 & 0,08 & 0,07 & 0,13 & 0,09 & 0,05 & 0,12 & 0,09 & 0,03 & 0,07 & 0,07 & 0,09 \\
\hline $\mathrm{TiO}_{2}$ & 0,04 & 0,04 & 0,00 & 0,06 & 0,01 & 0,00 & 0,00 & 0,00 & 0,04 & 0,00 & 0,01 & 0,00 & 0,00 & 0,04 \\
\hline $\mathrm{BaO}$ & 0,01 & 0,01 & 0,00 & 0,02 & 0,02 & 0,01 & 0,05 & 0,04 & 0,06 & 0,07 & 0,00 & 0,02 & 0,01 & 0,01 \\
\hline $\mathrm{Na}_{2} \mathrm{O}$ & 8,37 & 7,89 & 7,86 & 7,80 & 7,92 & 7,92 & 7,95 & 7,90 & 7,74 & 8,04 & 10,76 & 8,21 & 8,13 & 7,90 \\
\hline $\mathrm{MgO}$ & 0,00 & 0,00 & 0,00 & 0,00 & 0,00 & 0,00 & 0,00 & 0,00 & 0,00 & 0,00 & 0,02 & 0,00 & 0,00 & 0,00 \\
\hline Total & 100,50 & 100,35 & 100,59 & 100,35 & 100,13 & 100,75 & 100,57 & 99,75 & 99,26 & 99,96 & 99,68 & 100,18 & 99,92 & 100,24 \\
\hline An\% & 24,52 & 28,24 & 28,49 & 28,02 & 27,28 & 27,62 & 27,26 & 26,41 & . 27,99 & 27,18 & 4,69 & 26,45 & 26,50 & 28,71 \\
\hline
\end{tabular}




\section{PLAGIOCLÁSIO}

Amostra-

Cristal STX-282-1

STX-282-2

STX-282-3

STX-282-4

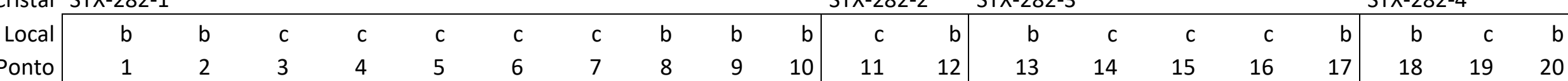

Óxidos (\%)

\begin{tabular}{|c|c|c|c|c|c|c|c|c|c|c|c|c|c|c|c|c|c|c|c|c|}
\hline $\mathrm{SiO} 2$ & 11,83 & 10,83 & 10,85 & 10,86 & 10,85 & 10,86 & 10,91 & 10,77 & 10,71 & 11,08 & 10,76 & 10,68 & 10,73 & 10,86 & 10,84 & 10,79 & 10,66 & 11,82 & 10,85 & 10,66 \\
\hline $\mathrm{Al} 2 \mathrm{O} 3$ & 4,20 & 5,24 & 5,21 & 5,19 & 5,21 & 5,18 & 5,17 & 5,29 & 5,34 & 4,99 & 5,30 & 5,36 & 5,30 & 5,19 & 5,20 & 5,26 & 5,40 & 4,22 & 5,20 & 5,38 \\
\hline 2 & 0,00 & 0,02 & 0,01 & 0,02 & 0,01 & 0,01 & 0,00 & 0,00 & 0,01 & 0,00 & 0,01 & 0,02 & 0,01 & 0,02 & 0,018 & 0,011 & 0,018 & 0,007 & 0,020 & 0,031 \\
\hline $\mathrm{MnO}$ & 0,001 & 0,002 & 0,004 & 0,004 & 0,000 & 0,000 & 0,001 & 0,000 & 0,000 & 0,000 & 0,000 & 0,001 & 0,001 & 0,002 & 0,00 & 0,00 & 0,00 & 0,00 & 0,00 & 0,00 \\
\hline $\mathrm{CaO}$ & 0,13 & 1,06 & 1,08 & 1,05 & 1,06 & 1,06 & 1,01 & 1,15 & 1,21 & 0,80 & 1,14 & 1,24 & 1,21 & 1,04 & 1,08 & 1,12 & 1,21 & 0,12 & 1,05 & 1,23 \\
\hline K2O & 0,02 & 0,06 & 0,06 & 0,05 & 0,04 & 0,04 & 0,04 & 0,03 & 0,03 & 0,03 & 0,03 & 0,03 & 0,06 & 0,08 & 0,069 & 0,080 & 0,047 & 0,020 & 0,048 & 0,031 \\
\hline $\mathrm{SrO}$ & 0,004 & 0,007 & 0,006 & 0,007 & 0,010 & 0,006 & 0,006 & 0,008 & 0,010 & 0,008 & 0,010 & 0,009 & 0,010 & 0,009 & 0,005 & 0,007 & 0,011 & 0,003 & 0,010 & 0,011 \\
\hline $\mathrm{TiO} 2$ & 0,007 & 0,000 & 0,001 & 0,002 & 0,000 & 0,000 & 0,000 & 0,000 & 0,000 & 0,005 & 0,005 & 0,004 & 0,001 & 0,000 & 0,000 & 0,006 & 0,000 & 0,006 & 0,002 & 0,002 \\
\hline $\mathrm{BaO}$ & 0,002 & 0,003 & 0,003 & 0,003 & 0,000 & 0,002 & 0,000 & 0,005 & 0,000 & 0,000 & 0,000 & 0,002 & 0,003 & 0,001 & 0,00 & 0,00 & 0,00 & 0,00 & 0,00 & 0,00 \\
\hline $\mathrm{Na} 2 \mathrm{O}$ & 3,74 & 2,71 & 2,72 & 2,74 & 2,75 & 2,81 & 2,80 & 2,71 & 2,64 & 3,05 & 2,68 & 2,63 & 2,64 & 2,73 & 2,73 & 2,67 & 2,61 & 3,76 & 2,77 & 2,63 \\
\hline $\mathrm{MgO}$ & 0,00 & 0,00 & 0,00 & 0,00 & 0,00 & 0,00 & 0,00 & 0,00 & 0,00 & 0,00 & 0,00 & 0,00 & 0,00 & 0,00 & 0,00 & 0,00 & 0,00 & 0,00 & 0,00 & 0,00 \\
\hline Total & 19,94 & 19,92 & 19,94 & 19,93 & 19,93 & 19,97 & 19,93 & 19,96 & 19,95 & 19,96 & 19,94 & 19,96 & 19,96 & 19,94 & 19,95 & 19,94 & 19,96 & 19,95 & 19,95 & 19,97 \\
\hline & 3,35 & 27,73 & 27,86 & 27,38 & 27,40 & 27,07 & 26,25 & 29,53 & 31,20 & 20,56 & 29,64 & 31,85 & 30,93 & 26,99 & 27,79 & 29,04 & 31,37 & 3,10 & 27,03 & 31,63 \\
\hline
\end{tabular}




\title{
Magmatic epidote and its petrological significance in Muniz Freire Batholith, Espírito Santo, Southeastern Brazil
}

\author{
Igor Eduardo Mascarenhas(1), Rômulo Machado(2).
}

(1)Programa de Pós-Graduação em Recursos Minerais e Hidrogeologia - Instituto de Geociências, Universidade de São Paulo, Rua do Lago, 562, Cidade Universitária, São Paulo, SP Cep: 05508-080, Brazil

(2)Instituto de Geociências - Universidade de São Paulo, Rua do Lago, 562, Cidade Universitária, São Paulo, SP Cep: 05508-080, Brazil

\section{Abstract}

Magmatic epidote is a mineral with great petrological significance. Textural evidences in Muniz Freire Batholith, a biotite granite to tonalite from Espírito Santo, Brazil, shows that epidote in this rock is of primary origin. The most important textures are allanitic cores and corroded boundaries when in contact with the quartz-feldspatic matrix. Crystallization-order based geobaromether indicates a minimum pressure of $8 \mathrm{kbar}$ for epidote genesis and evidences points to a rather fast magma ascension. Epidote in this rock is metastable in granodioritic compositions, but stable in tonalites. Two possible P-T conditions of emplacement could be constrained: a maximum range of $8-19 \mathrm{kbar}$ and temperature of $700^{\circ} \mathrm{C}$ to $775^{\circ} \mathrm{C}$ or a minimum range of $8-10 \mathrm{kbar}$ and $700^{\circ} \mathrm{C}$ to $750^{\circ} \mathrm{C}$.

Keywords: Magmatic epidote, Muniz Freire Batholith, Petrographic criteria

\section{INTRODUCTION}

Epidote is a well-known metamorphic and secondary mineral in granitoid rocks. However, it was until 1983, when experiments carried out by Naney resurrected a long forgotten knowledge: the epidote can crystallize directly from granitic magmas. This was first cited by Cornelius (1915) when studying the Bergell tonalite in Alps. This body of tonalite is an intrusive sheet post regional metamorphism that cuts the pile of rocks of the Pennine and Austroalpines nappes producing contact metamorphism (Trommsdorff and Connolly, 1996). Cornelius (1915) recognized textural relations that, together with field observations, led to the conclusion that epidote was a primary mineral in that rock. Tulloch (1979), prior to Naney's experiments, concluded on the basis of textural relations, that epidote occurred as an "early, probably magmatic phase, enclosed within biotite of the Rahu suite (...) It is presumed that this epidote crystalized prior to the final emplacement of these plutons", but hard evidences were still lacking.

Naney's experiment consisted on observing crystallization sequences on a granodioritic synthetic glass. The experiment was carried out under pressure of $2 \mathrm{kbar}$ and $8 \mathrm{kbar}$, at various temperatures (ranging from $550^{\circ} \mathrm{C}$ and $1200^{\circ} \mathrm{C}$ ) and water contents ranging from anhydrous to saturated conditions. Oxygen fugacity for this experiment was set between $\mathrm{HM}$ and $\mathrm{NiNiO}$. The results showed that at pressures of $8 \mathrm{kbar}$, in a temperature between the solidus at $600^{\circ} \mathrm{C}$ and about $700^{\circ} \mathrm{C}$ (increasing with water content by about $10^{\circ} \mathrm{C}$ ), epidote could crystalize with biotite and plagioclase, indicating an stability field for epidote in magmatic conditions. Evans and Vance (1987) contributed with their findings in Boulder County, 


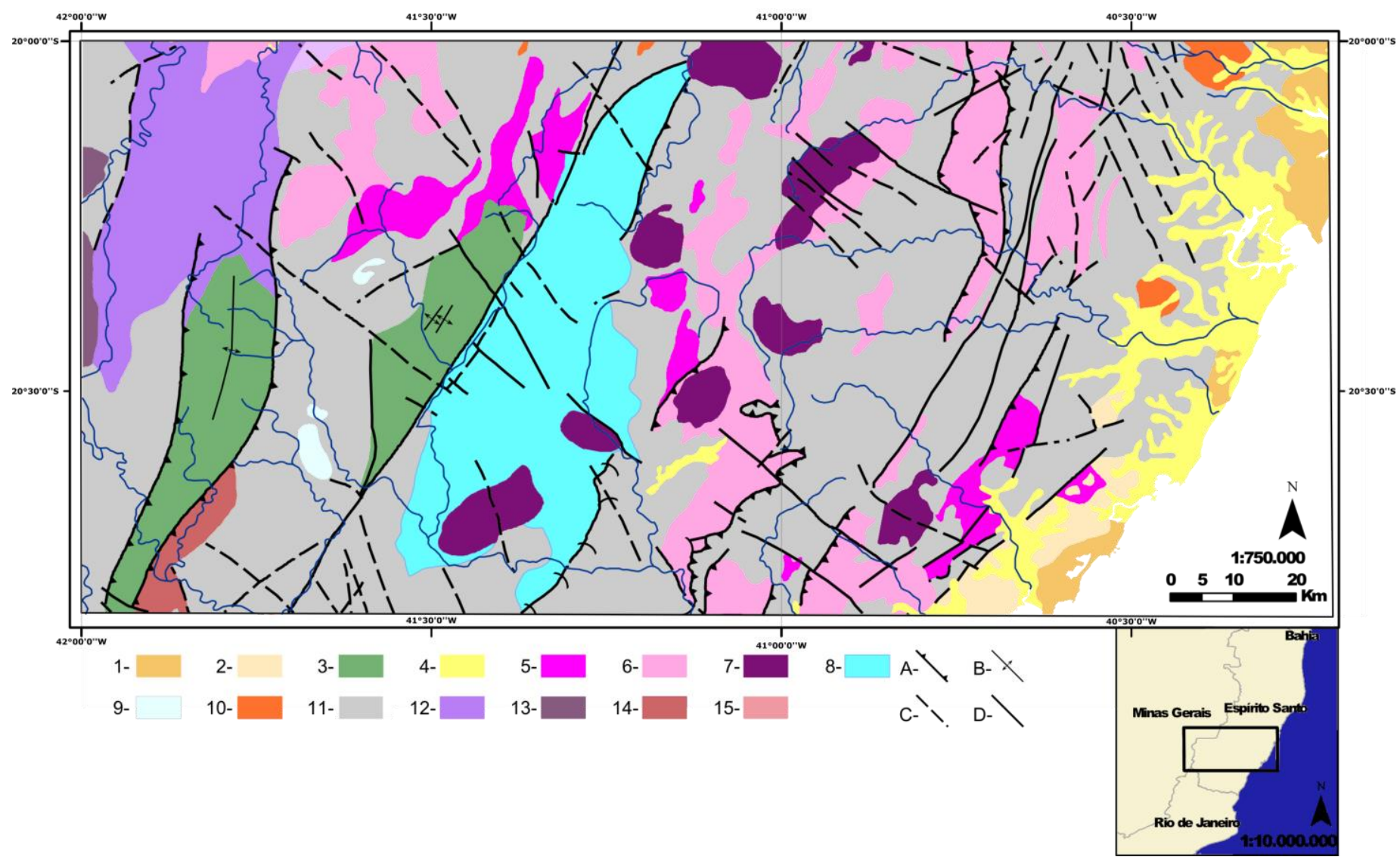

Figure 1. Geological map of study area and surroundings. 1- Barreiras Group; 2- Bela Joana; 3- Caparaó Suite and charnockitoids; 4- Quartenary deposits; 5- Concórdia, São Benedito, Brejatuba, Alfredo Chaves, Alto Viçosinha, Limoeiro and Santa Maria de Baixo granitoids; 6- Pau-de-Óleo, Colatina, Santa Tereza and São Gabriel da Baunilha granitoids; 7- I-type granitoids and Afonso Cláudio, Alto Chapéu, Garrafão, Rio Novo do Sul, Santa Angélica, Areçê, Venda Nova and Castelo massifs; 8- Batólito Muniz Freire; 9- Muniz Freire Suite; 10- Palmital do Sul; 11- Paraíba do Sul complex; 12- Pocrane complex; 13- Muriaé Suite; 14- Araçuaí Orogen Mafic rocks; 15- Natividade Suite. A- Reverse fault, thrust fault or transpressional shear zone B- Anticlinal or normal antiform; C- inferred fault or fracture; D - transcurrent shear zone. Modified from Silva et al. (2004)

Colorado, EUA, where Late Cretaceous rhyodacitic dikes showed Epidote phenocrysts, confirming the existence of epidote as a primary phase.

This breakthrough led petrologists to study magmatic epidote stability field and this triggered a researcher's interest in the research for its petrologic significance. To achieve that, many epidote-bearing igneous rocks were studied in order to better understand the behaviour of epidote in magmatic evolution, its implications in pressure, temperature, oxygen fugacity and possible calculations on uplift rates (Zen and Hammastrom, 1984, Schmidt and Thompson, 1996, Brandon et al., 1996, Schmidt and Poli, 2004).

In Brazil, Sial (1990, 1993), Sial et al. (1999, 2008) described magmatic epidote in calc-alkaline plutons of Northeast Brazil, in Borborema province, being the only reliable report of primary epidote in this country until Narduzzi et al. (2017) described magmatic epidote in Araçuaí Belt, Southeast Brazil.

\section{GEOLOGIC SETTING}

The Muniz Freire Batholith (MFB) is one of many intrusive granitic bodies in the Late NeoproterozoicCambrian Araçuaí Orogen. This orogen is often interpreted as the Brazilian counterpart of African WestCongo Orogen and some questions about its evolution remain unanswered. While some authors interpret this orogen as product of a intraplate orogeny or ensialic evolution (Siga Jr. 1986; Trompette, 1994), a new classification came up by Pedrosa-Soares et al. (2001) and Rogers and Santosh (2004) due to its peculiar 
setting "confined to a cratonic embayment" called "confined orogen". The Araçuaí Orogen exhibit all geotectonic components (processes evidences and products) resultants from a collisional orogeny, as precursor basin, rift magmatism, continental magmatic arc, ophiolites and sin- to late collisional magmatism. As such, it is interpreted as a confined orogen, formed by the closure of Adamastor Ocean, which has been interpreted as a gulf with limited generation of oceanic lithosphere (Pedrosa-Soares et al., 2001, 2008, 2011). Models involving microplates, suspect terranes have been also proposed (Campos-Neto and Figueiredo, 1995; Costa et al., 1995).

Due to its remarkable exposure of plutonic bodies, aside with portuary infrastructure, the states in which Araçuaí Belt is located are significant ornamental rocks producers (Signorelli, 1993). These bodies provide valuable information to understand the evolution of Araçuaí Belt, and the available data allowed to subdivide the Neoproterozoic-Cambrian granitic magmatism of this belt in separated stages (supersuites) related to the evolution of the orogen. Pedrosa-Soares et al. (1999, 2001, 2011) and PedrosaSoares and Wiedmann-Leonardos (2000) subdivide this magmatism in five stages: G1, pre-collisional stage (625-595 Ma), representing the building of a magmatic arc, with type-I granitic-ortogneiss batholiths; G2, sincollisional stage (595-575 Ma), with granitogenesis related to partial melting of crust due to crustal thickening generating peraluminous S-type granites; G3, late- to post-collisional stage (545-525 Ma), when granitoids are generated by the transition between convergent forces to extensional relaxation and crustal delamination towards the climax of the gravitational collapse of the orogen. G3 granitoids are sub-alkaline peraluminous undeformed S-type granites spatially connected to G2 bodies; G4 (530-500 Ma) and G5 (520$480 \mathrm{Ma}$ ), post-collisional stage, mainly including peraluminous sub-alkaline S-type and metaluminous calc-alkaline to alkaline $I$ - to $A$ - type granitoids respectively, both related to the gravitational collapse of the orogen.
The MFB is referred as an important member of the pre-colisional G1 Supersuite (Pedrosa-Soares et al. 2001, 2011, De Campos et al., 2004). It is located on southernmost part of Araçuaí Orogen, with an exposure of $680 \mathrm{~km}^{2}$. Its western border is in contact with the Guaçuí Shear Zone, and its eastern border is an intrusive contact with rocks of the Paraíba do Sul Complex. It is described as a granitoid-gneiss of granitic composition, minor granodioritic to tonalitic composition, milonitic texture, coarse- to mediumgrained, locally porfiritic. (Signorelli, 1993). Decimetric leucogranitic dykes are intrusives in the batholith and can be seen cutting the rounded hills typical of this lithology. Age determination by LA-ICP-MS U-Pb zircon yielded a value of $588 \pm 4 \mathrm{Ma}$ (Pedrosa-Soares, 2011). According to these authors, this value is considered the magmatic crystallization age of the Estrela-Muniz Freire Batholith.

Biotite is the main mafic phase; however, hornblende and garnet may be present in some samples. Apatite, epidote, zoisite, allanite, titanite, chlorite, muscovite and zircon are the accessory mineral phases. Plagioclase is oligoclase (15-20\% An). Deformation textures (chessboard quartz, poligonized plagioclase and K-feldspar contacts) indicate a high temperature deformation, but not pervasive enough to destroy K-feldspar and plagioclase primary crystals and impose asymmetric features. Whole-rock geochemistry characterizes the MFB rocks as a slightly peraluminous magmatism (mean $\mathrm{A} / \mathrm{CNK}=1.15$ and $\mathrm{A} / \mathrm{NK}=1.5$ ), high- $\mathrm{K}$ calc-alkaline nature, LILE and Light-REE elements enrichment and major elements behaviour compatible with fractionation processes (Mascarenhas, 2015). Textural evidences shows that epidote might be a primary mineral phase.

\section{IDENTIFYING MAGMATIC EPIDOTE}

To better understand magmatic epidote petrological meaning, some questions must be answered first. The most fundamental one is: How do one identifies magmatic epidote? Schmidt and Poli (2004) wrote a review on most known textural evidences that might occur on magmatic epidote- 
bearing intrusive rocks. It is important to note that, although many authors still use some chemical criteria, these "are not very helpful to distinguish magmatic from metamorphic epidote: the metamorphic compositional

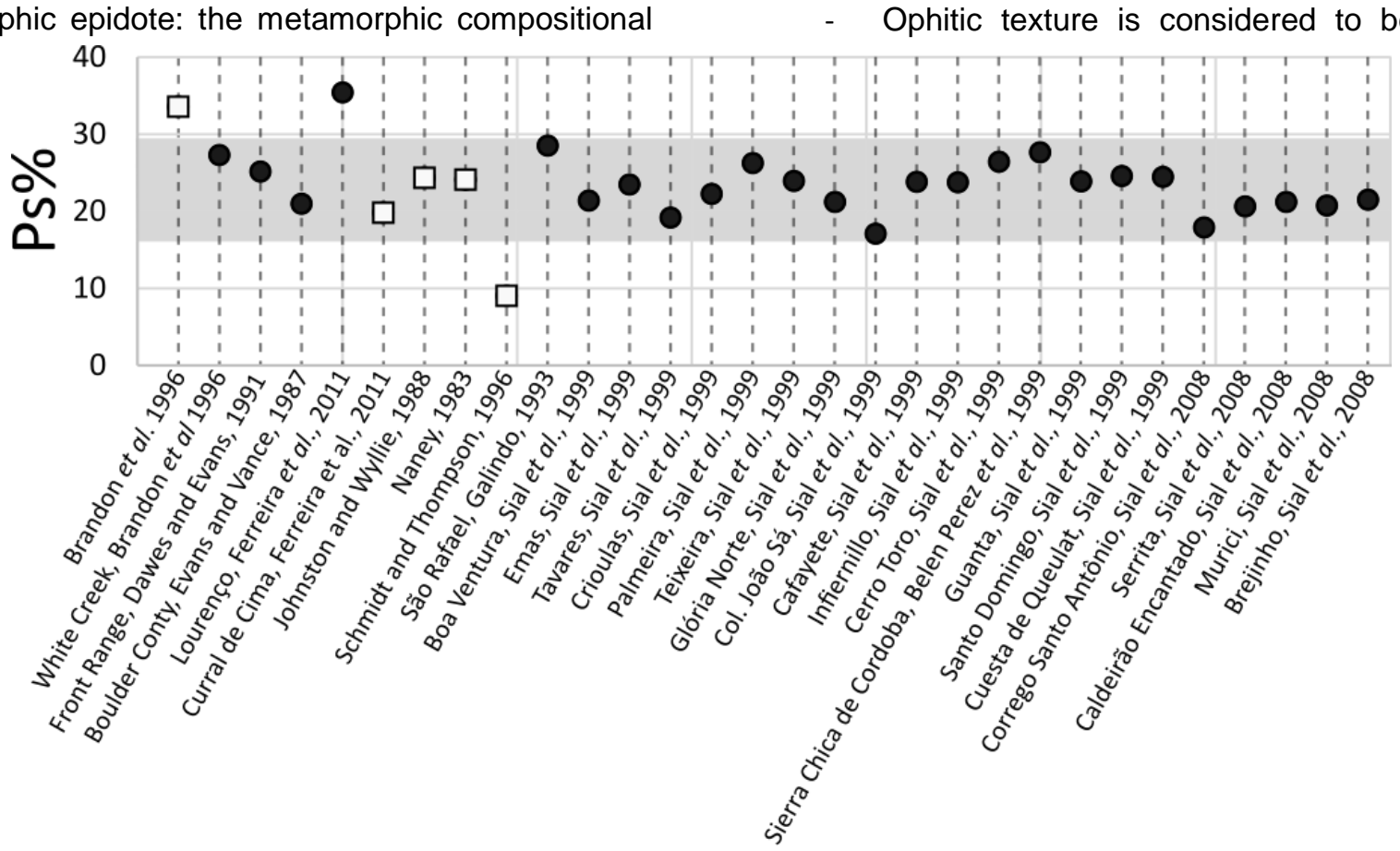

Figure 2. Pistacite content of 30 different samples of primary epidote. Squares are experiments and circles are natural occurrences. Grey area shows usual primary epidote content for these samples. Core data were chosen over rim data when both were available

array (pso to $\mathrm{ps}_{100}$ ) encompasses the magmatic compositional array (typically ps 30 to ps70)" ('ps' meaning the mole percentage of pistacite defined as $\left.100^{*}\left[\mathrm{Fe}^{+} /\left(\mathrm{Fe}^{+}+\mathrm{Al}\right)\right]\right)$. Figure 2 presents ps content of 30 samples from other works, showing that most magmatic epidote composition from these works are encompassed between ps18-30, with a few exceptions, such as Schmidt and Thompsom's (1996) experiment. This specific sample crystalized under high pressure and near-solidus temperature, showing that ps content might be different in epidote under these conditions.

\subsection{Textural evidence for magmatic} epidote:

The most reliable petrographic evidences to identify magmatic epidote were compiled by Schmidt and Thompsom (1996) and Schmidt and Poli (2004) and are listed as follow:
- Reliable indication of strong zonation, with allanite-rich cores. The lack of this zonation do not exclude a magmatic origin;

- Ophitic texture is considered to be typically 


\subsection{Mineral Chemistry}

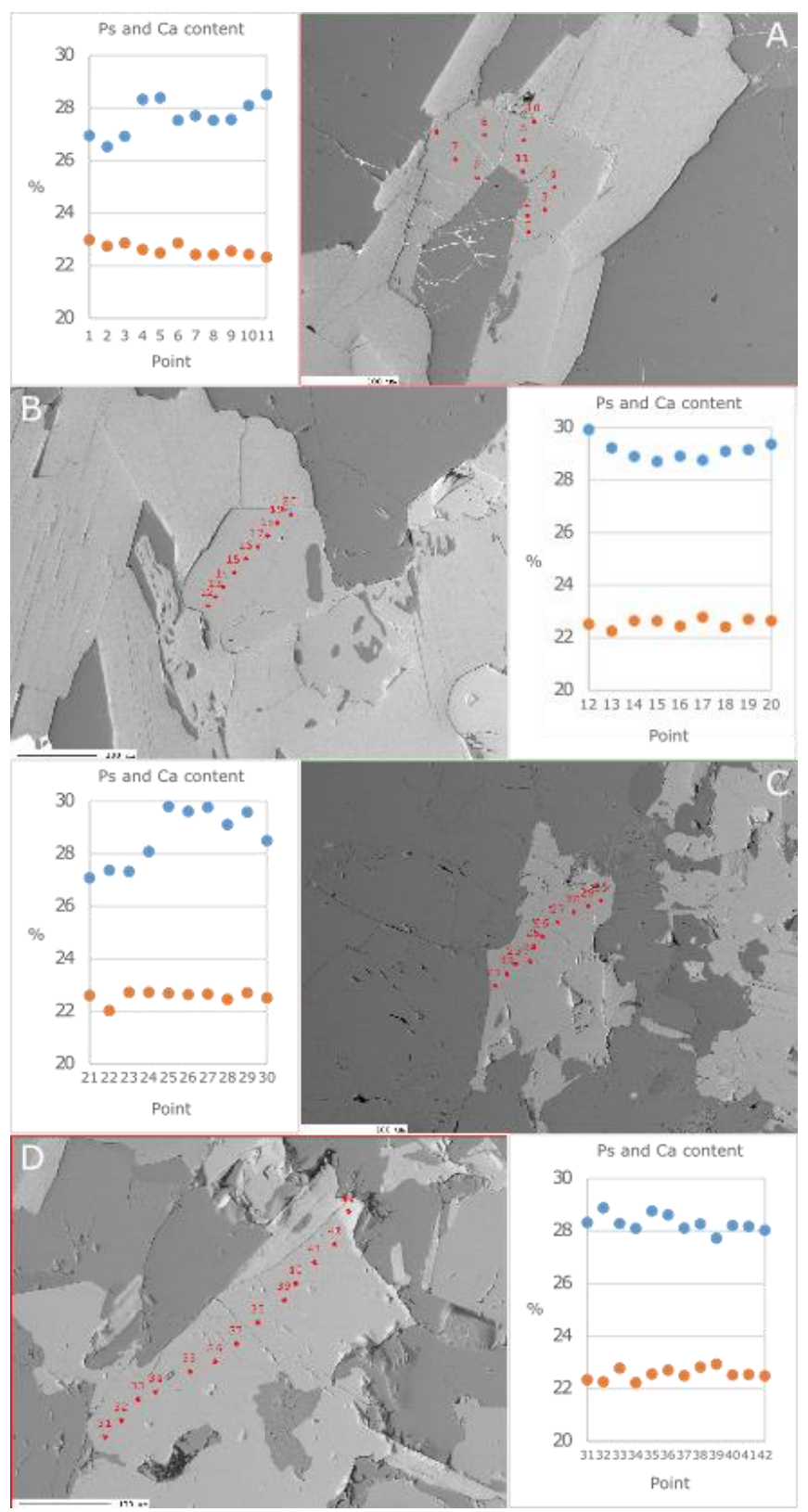

Figure 3. Epidote analytical profiles. Analysis that does not

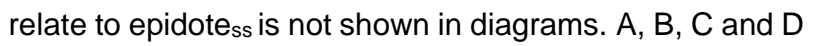
are from sample PMF-14A

Chemical analysis of epidote has been performed at the electron microprobe laboratory at University of São Paulo, Brazil, using a JEOL JXA8600S microprobe. The instrument was operated at a beam current of 15 $\mathrm{nA}$, acceleration voltage of $15 \mathrm{kV}$ and beam diameter of $5 \mu \mathrm{m}$. Rim-Core profiles were made in seven epidote crystals with or without allanite cores (figure 3 and 4), showing little to no zoning. Pistacite content (Ps\%) in crystals range from 26 to $30 \%$ (table 1), a content compatible with Naney's experiment for granodiorite rocks, but means very little as shown by Schmidt and Poli (2004), since Ps content around $25-30 \%$ is not a distinguishing feature of a primary origin, as believed by previous authors and explained above. It is worth noting that Sial et al. $(1999,2008)$ used as criteria in order to identify the magmatic origin of an epidote crystal its $\mathrm{TiO}_{2}$
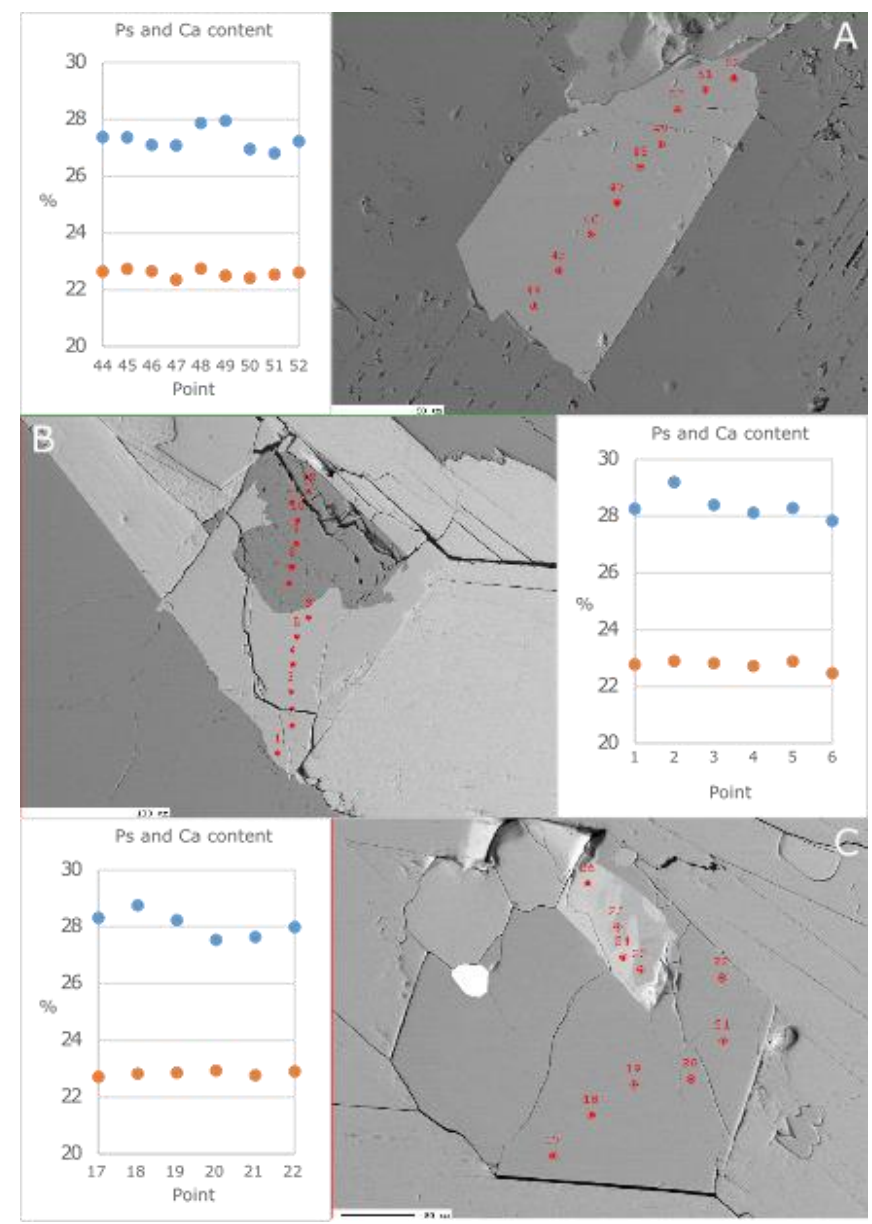

Figure 4. Epidote analytical profiles. Analysis that does not

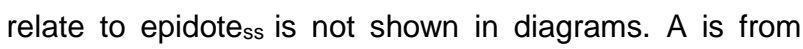
sample PMF-14A, B and C are from sample STX-282

content, citing Evans and Vance (1987) work. However, there is no such criterion in this work, leading to think that one of two mistakes were made: either this criterion was some other works conclusion, but was mistakenly cited, or the criterion is wrong, probably mistaken by other kind of criterion. Since the sentence is very specific ("and the criteria (sic) by Evans and Vance (1987) who show that magmatic epidote typically has $<0.2$ wt. $\% \mathrm{TiO}_{2}$, whereas secondary epidote replacing biotite has $>0.6 \mathrm{wt} . \% \mathrm{TiO}_{2}$ ") one might conclude that this is the case of a wrong reference. Nagar and Korakoppa (2014) use a similar criterion to identify magmatic 
Análises quantitativas obtidas por WDS de elementos maiores e traços em epídoto do Batólito Muniz Freire

\begin{tabular}{|c|c|c|c|c|c|c|c|c|c|c|c|c|c|c|c|}
\hline \multirow{2}{*}{$\begin{array}{l}\text { Cristal } \\
\text { Local }\end{array}$} & \multirow{2}{*}{$\frac{\text { PMF14A-1 }}{\text { Centro }}$} & \multirow{2}{*}{ Borda } & \multicolumn{2}{|c|}{ PMF14A-2 } & \multicolumn{2}{|l|}{ PMF14A-3 } & \multicolumn{2}{|c|}{ PMF14A-4 } & \multicolumn{2}{|l|}{ PMF14A-5 } & \multicolumn{2}{|l|}{ STX282-1 } & \multirow{2}{*}{$\begin{array}{l}\text { STX282-2 } \\
\text { Centro }\end{array}$} & \multirow{2}{*}{$\begin{array}{l}\text { STX282-3 } \\
\text { Centro }\end{array}$} & \multirow[b]{2}{*}{ Borda } \\
\hline & & & Centro & Borda & Centro & Borda & Centro & Borda & Centro & Borda & Centro & Borda & & & \\
\hline $\mathrm{Si}$ & 37,82 & 37,47 & 37,63 & 37,24 & 37,37 & 37,48 & 37,36 & 37,41 & 37,46 & 37,46 & 37,57 & 37,77 & 37,65 & 37,75 & 37,81 \\
\hline$Y$ & 0,00 & 0,00 & 0,02 & 0,00 & 0,00 & 0,04 & 0,00 & 0,00 & 0,00 & 0,00 & 0,00 & 0,00 & 0,00 & 0,00 & 0,00 \\
\hline $\mathrm{Fe}$ & 13,85 & 13,85 & 14,43 & 14,57 & 14,82 & 13,6 & 14,26 & 14,11 & 13,61 & 13,62 & 14,17 & 14,30 & 14,13 & 14,27 & 14,20 \\
\hline $\mathrm{Mn}$ & 0,31 & 0,38 & 0,56 & 0,49 & 0,40 & 0,34 & 0,35 & 0,36 & 0,28 & 0,34 & 0,28 & 0,32 & 0,28 & 0,35 & 0,33 \\
\hline $\mathrm{Ca}$ & 22,43 & 22,43 & 22,45 & 22,65 & 22,65 & 22,61 & 22,83 & 22,34 & 22,35 & 22,61 & 22,73 & 22,78 & 22,63 & 22,86 & 22,91 \\
\hline Th & 0,12 & 0,00 & 0,00 & 0,00 & 0,00 & 0,17 & 0,00 & 0,29 & 0,02 & 0,04 & 0,00 & 0,00 & 0,00 & 0,07 & 0,03 \\
\hline $\mathrm{Ti}$ & 0,15 & 0,07 & 0,10 & 0,16 & 0,02 & 0,06 & 0,06 & 0,11 & 0,14 & 0,12 & 0,07 & 0,03 & 0,06 & 0,09 & 0,10 \\
\hline La & 0,06 & 0,00 & 0,01 & 0,02 & 0,00 & 0,00 & 0,02 & 0,01 & 0,02 & 0,06 & 0,03 & 0,00 & 0,03 & 0,00 & 0,01 \\
\hline $\mathrm{Ce}$ & 0,00 & 0,00 & 0,00 & 0,06 & 0,00 & 0,00 & 0,00 & 0,00 & 0,046 & 0,00 & 0,04 & 0,00 & 0,01 & 0,00 & 0,00 \\
\hline $\mathrm{Al}$ & 23,06 & 23,27 & 22,65 & 22,37 & 22,49 & 23,38 & 23,11 & 22,80 & 23,39 & 23,24 & 23,12 & 23,17 & 23,14 & 23,16 & 23,33 \\
\hline $\mathrm{Mg}$ & 0,00 & 0,04 & 0,012 & 0,02 & 0,01 & 0,01 & 0,02 & 0,01 & 0,00 & 0,00 & 0,01 & 0,014 & 0,05 & 0,03 & 0,05 \\
\hline Total & 97,80 & 97,51 & & & 97,76 & 97,70 & 98,02 & 97,45 & 97,32 & 97,50 & 98,03 & 98,39 & 97,97 & 98,58 & 98,77 \\
\hline Ps & 27,72 & 27,54 & 28,92 & 29,37 & 29,61 & 27,08 & 28,26 & 28,32 & 27,09 & 27,23 & 28,13 & 28,27 & 28,05 & 28,23 & 27,99 \\
\hline
\end{tabular}

epidote without actual specific citation ("Distinguishing magmatic from secondary epidote is not straightforward, but can be achieved through various textural and chemical criteria (Tulloch, 1979, Zen and Hammastrom, 1984, Evans and Vance, 1987, Johnston and Wyllie, 1988, Vyhnal et al. 1991). Presence of allanite in the core, embayed contact, Ps content (mostly 25 to 32 ) and very low $\mathrm{TiO}_{2}(<0.02 \%)$ attest the magmatic origin of epidote recorded in the studied granitoids"), but none of these works describe such criteria. Since there is probable doubt in using $\mathrm{TiO}_{2}$ content as a distinguishing feature of magmatic epidote, it will not be used here, despite all epidote chemical analysis indicate $\mathrm{TiO}_{2}<0.2 \%$.

Although Ps content is not a distinguishing feature of primary epidote, as stated above and wellillustrated by figure 5 from Johnston and Wyllie (1988), figure 2 shows that most (presumed) MEp from works and experiments worldwide have around 18-30 Ps content with little deviation. Some results are rather odd, like Schmidt and Thompson's (1996) experiment, but this, specifically, was conducted under non-usual conditions - HM-buffered tonalite, $18 \mathrm{kbar}$ and $650^{\circ} \mathrm{C}$, that is, under oxidising conditions, high pressure and near-solidus temperature - whereas most analysis from other works are in general granodiorites-tonalites, with pressure around 8-10 kbar and NNO-buffered. So, although authors don't quite understand what variables control Ps content in MEp, it is clear that different

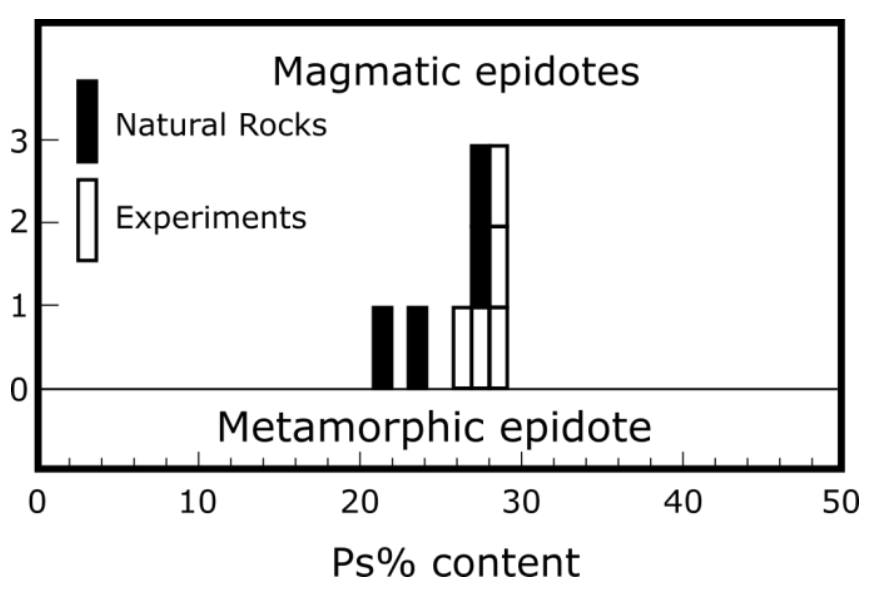

Fig. 5 Histogram showing magmatic epidote compositions from natural rocks, experimental run products and range of metamorphic epidote compositions. Taken from Vynhal and Wyllie (1988) and compositions are in references therein.

conditions might affect $\mathrm{Fe} / \mathrm{Al}$ ratio. In general, if a epidote crystal is present in a rock that respect most usual conditions as mentioned above, it's Ps content will probably be constrained in the 18-30 Ps\% area. But as shown in figure 5 , Ps content alone is not enough to characterize the magmatic epidote since metamorphic epidote might have the same Ps content as the most usual and unusual MEp.

Mineral chemistry analysis data are presented in table 1 in a simplified manner (rim-core), although more analysis have been performed, as shown by figures 3 and 4 . There is one way that mineral chemistry can help one to identify the primary character of a epidote crystal, 
and that is, as stated by Schmidt and Poli (2004), the "indication of strong zonation". Since most substitution in epidote crystals happens between $\mathrm{Fe}-\mathrm{Al}$ and $\mathrm{Ca}-$ have been submitted to different processes in the same sample and an explanation to this core-rim profile inversions is difficult to explain. But these crystals have,

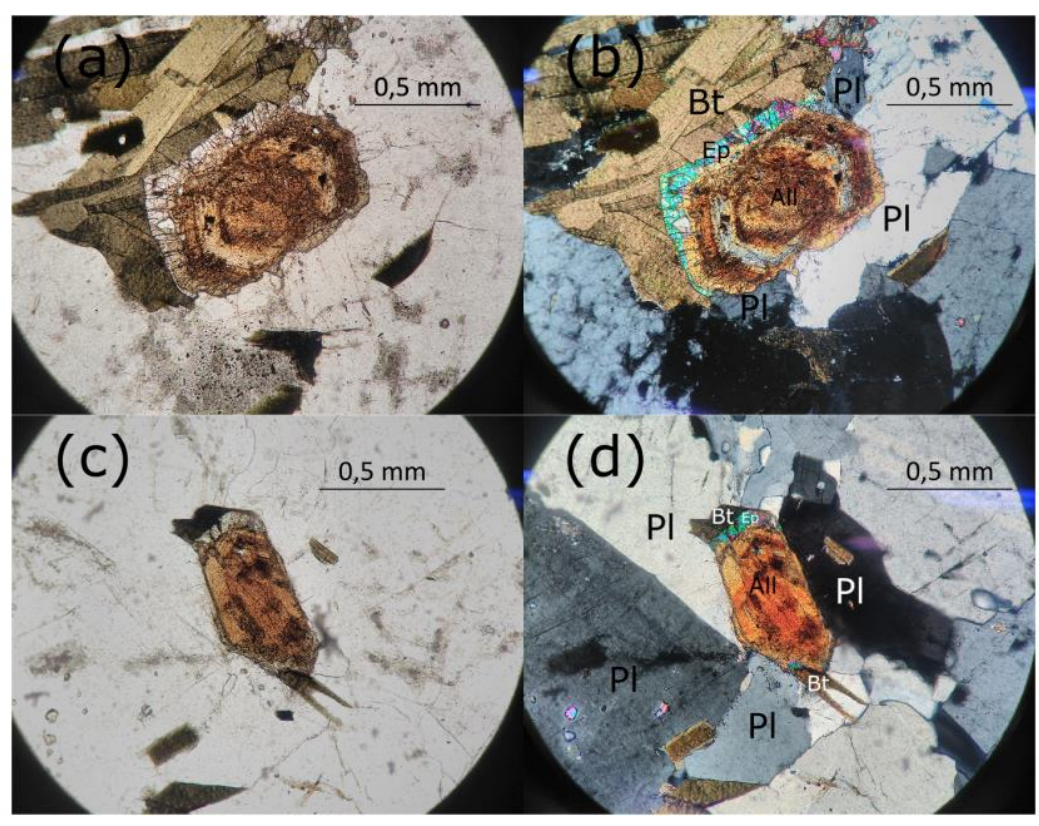

Figure 6. Thin sections photographs showing epidote with allanite cores and resorption textures. Epidote is resorbed when in contact with quartz-feldspatic matrix, and preserved when in contact to biotite. All photos are from sample STX-282. (b) and (d) were taken with crossed polarizers

ETR (La, Ce, Y), figures 3 and 4 shows point analysis of $\mathrm{Ca}$ and Ps contents. Ca contents are usually stable, showing that there is little to no substitution with ETR. However, Ps contents somewhat varies between core and rim, sometimes with a core richer in $\mathrm{Fe}$, sometimes richer in $\mathrm{Al}$, but showing a chemical zoning nonetheless. This chemical zoning cannot be seen in petrography, and possibly, epidote crystals could mostly homogenize during its crystallization. As noted in Schmidt and Thompsom (1996) experiments, "Epidote is relatively Fe-rich at low pressures (Ps 21 at $6.5 \mathrm{kbar}(\ldots))$ however, Fe contents decrease with pressure to about $\mathrm{Ps}_{10}$ near 10 kbar and to Ps8 near $18 \mathrm{kbar}\left(\right.$ at $\left.650^{\circ} \mathrm{C}\right)$ ", so it is safe to assume that pressure is somewhat important when comparing Ps contents. However, many variables might or might not affect this, such as rock composition, $\mathrm{fO}_{2}$ and temperature. In the same rock, we can see a core slightly rich in $\mathrm{Fe}$ and, on the contrary, the Fe-rich rim. Assuming these epidote crystals have been crystalized simultaneously or from a liquid of the same composition, as it is possible to see in petrography analysis and crystallization order, these crystals probably couldn't without doubt, chemical zoning.

\subsection{Petrography}

Petrographic studies from samples of MFB shows very little mineralogical and textural heterogeneity over different samples collected from the batholith. Quartz-alkalifeldspar-plagioclase rate grades from granodiorite to sienogranitic, subordinately tonalitic, with biotite as main mafic mineral and often containing minerals from epidote group, titanite, muscovite, chlorite, garnet, zircon and hornblende as accessories phases, but hornblende is a main mafic phase aside with biotite in tonalitic samples. Microgranitic samples are usually granitic in composition. Most samples are fine- to mediumgrained, and show minor foliation defined by oriented tabular biotite crystals and granoblastic domains of prismatic minerals. This structure might be more or less pronounced, possibly forming a banding with millimetric alignment of biotite crystals. Porphyritic texture is present, usually formed by K-feldspar or plagioclase phenocrysts involved by a fine-grained matrix, 
sometimes deformed. Although quartz might be rather coarse when compared with other minerals, this might be due to deformation rather than crystallization, so porphyroblastic texture is also present. K-feldspar and plagioclase phenocrysts are usually subhedral and show little to no deformation or recrystallization, indicating a primary origin for those crystals and their relative textures. The samples are mainly unaltered, but some of them might show very fine muscovite in substitution of plagioclase. These samples usually are related to structures that cut or border the MFB. $600^{\circ} \mathrm{C}$, implying that strain was applied during late cooling phase (Hirth and Tullis, 1992; Kruhl, 1996; Avé'Lallement and Carter, 1999; Stipp et al. 2002).

Most accessory phases occur in aggregates of these minerals and biotite crystals, probably because they shared early phase crystallization, and during ascension, crystals might get together in melt. This is rather apparent with epidotess. In granodioritic rocks, these crystals only occur in contact to biotite, implying, as state above, that when epidotess is not stable under

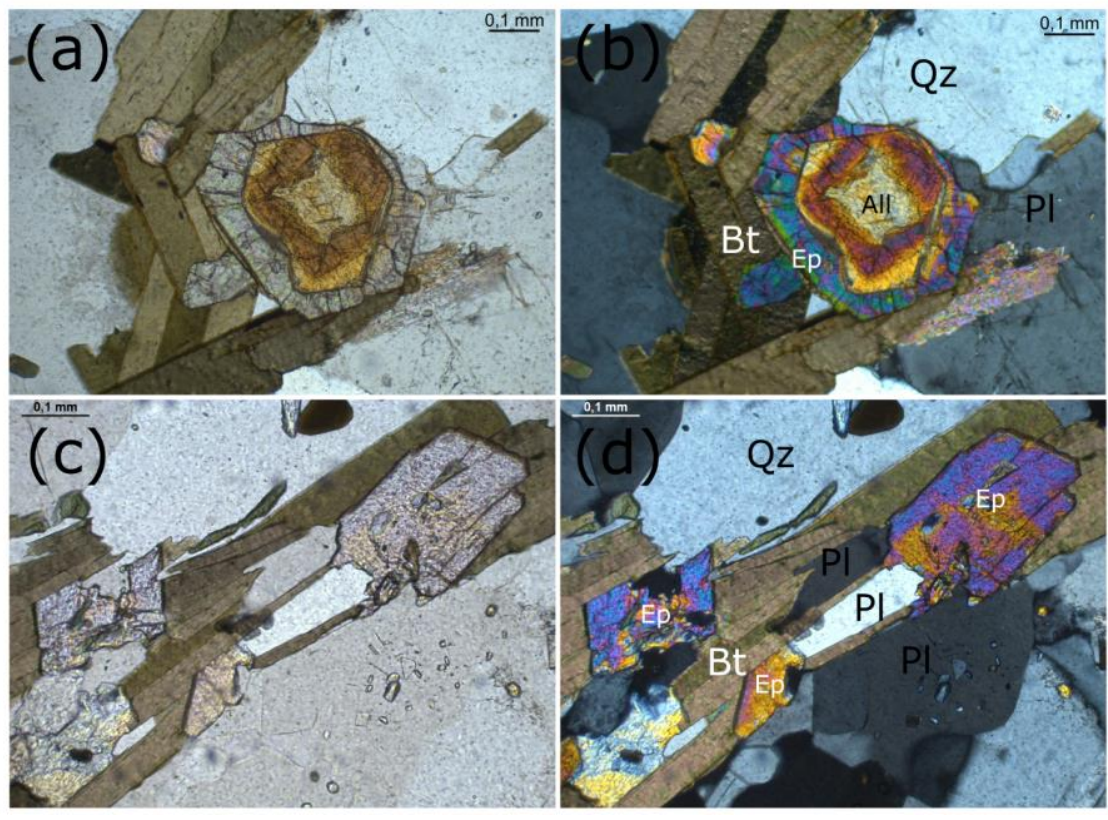

Figure 7. Thin section photographs of samples STX-278 ((a) and (b)) and STX 279A ((c) and (d)). (a) and (b) show a epidote with allanitic core, partially absorbed when in contact with a quartz-feldspatic matrix. Boundaries are straight when in contact with biotite, suggesting that this particular epidote crystal was originally of euhedral shape. (c) and (d) shows epidote in contact with biotite and quartz-feldspatic matrix. Epidote shows little to no corrosion when in contact with the quartz-feldspatic matrix, implying that for this rock, most of crystallization underwent inside epidote stability field.

There are features with clear evidence of a solidstate deformation overprinting originally igneous textures that are preserved in zones of low deformation. Since the composition of granitic rocks is essentially quartz-feldspatic, metamorphic conditions based on paragenesis are difficult to define. However, quartz and feldspar deformation textures might give some clues about the metamorphism grade that affected those rocks. K-Feldspar and plagioclase show granoblastic texture with polygonal contacts, suggesting about $600^{\circ} \mathrm{C}$ minimum temperatures during deformation (Passchier and Trouw, 2005) while quartz shows chessboard extinction, indicating a temperature of over certain conditions, it is resorbed by the quartzfeldspathic matrix. So epidotess needs to be in contact with other minerals in order to survive magma ascension. This is very clear in figure 6, which shows that when the epidote ss $_{\text {in }}$ in contact with biotite, it is still present; on the contrary, while it is in contact with quartz-feldspatic matrix, the epidotess is resorbed to its allanitic core. This is not true for thin sections of figure 7. In the first case (figure 7(a) and 7(b)), epidote in this sample is not resorbed whole, but partially, with irregular contacts with the quartz-feldspatic matrix. Figure 7(c) and 7(d). Epidote crystals does not show in in a tonalitic sample clear resorption textures, implying 


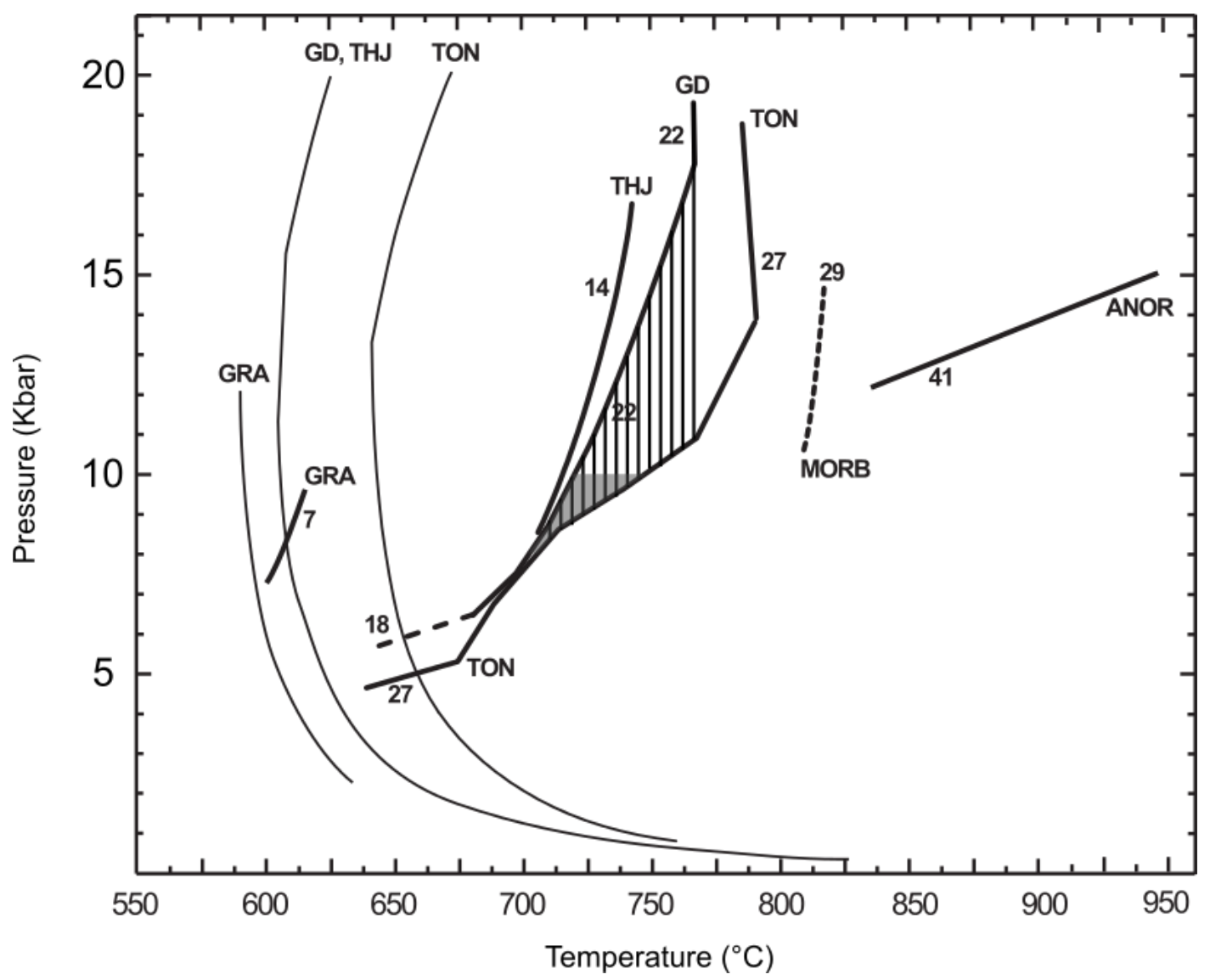

Figure 8. Solidi (thin lines) and reactions delimiting magmatic epidote stability (bold lines) for different magma compositions and $\mathrm{H}_{2} \mathrm{O}$ saturated. ANOR: anorthosite, GD: granodiorite, GRA: granite, MORB: mid-ocean ridge basalt, THJ: trondhjemite, TON: tonalite. Hatched area corresponds to P-T conditions the MFB probably crystalized if a minimum pressure of 8 kbar is considered while the grey area considers only the 8 to 10 kbar gap.

that for tonalitic compositions, epidote is stable even in the pressure and temperature conditions that the MFB crystallized.

\section{DISCUSSION}

Once it is stablished that epidote in MFB is of primary origin, some interpretations can be made. Schmidt and Poli (2004), based on several empirical data, came up with a barometer for hydrated granodiorites buffered by NNO with magmatic epidote. It is possible estimate epidote crystallization pressure using the first appearance of epidote during the crystallization history.

above 10 kbar: hornblende $\rightarrow$ epidote $\rightarrow$ plagioclase $\rightarrow$ biotite $\rightarrow$ quartz $\rightarrow$ K-feldspar;

10 to 8 kbar: hornblende $\rightarrow$ plagioclase $\rightarrow$ epidote $\rightarrow$ biotite $\rightarrow$ quartz $\rightarrow$ K-feldspar;
8 to 6 kbar: hornblende $\rightarrow$ plagioclase $\rightarrow$ biotite $\rightarrow$ epidote $\rightarrow$ quartz $\rightarrow$ K-feldspar;

6 to 5 kbar: hornblende $\rightarrow$ plagioclase $\rightarrow$ biotite $\rightarrow$ quartz $\rightarrow$ epidote $\rightarrow$ K-feldspar.

Thin section studies (Fig 6 and 7 ) indicate that the epidote crystallized before of the biotite, which suggests a minimum crystallization pressure of 8 kbar. However, crystallization order between epidote and plagioclase is unclear in most samples due to resorption textures. In sample STX-279A (Tonalite, figure 7(c) and (d)), plagioclase and epidote can be in contact showing little or no resorption, but crystallization order, although suggesting epidote is older than plagioclase, cannot be identified, allowing two different interpretations: epidote is older than plagioclase, indicating pressures above 10 kbar, or plagioclase is older than epidote, restricting pressure to $10-8 \mathrm{kbar}$. 
Schmidt and Poli (2004) also designed a diagram showing stability fields for epidote in rocks of various compositions. Since the MFB have the peculiar situation where epidote is metastable in granodioritic composition and stable in tonalitic composition, it is possible to constrain epidote stability field for this rock and deduce MFB P-T path.

First, the MFB probably rose fast enough to avoid total epidote consumption in some samples (STX-278, figure 7 (a) and (b)), which implies that pressure drop was not accompanied by a large temperature decrease. Since epidote was stable in granodioritic compositions at some point of MFB crystallization, this means that MFB started to crystallize this mineral inside epidote stability field of granodiorites. However, epidote became metastable with pressure drop, implying that the MFB pressure decreased enough to cross epidote stability line. Epidote in MFB is also stable for tonalitic composition. This means that the final pressure and temperature before total crystallization was inside epidote stability field for tonalites. Overall, the final P-T conditions for MFB should be inside the hatched area for figure 8. This suggests that the final pressure conditions would be above $8 \mathrm{kbar}$, which agrees well with Schmidt and Poli (2004) barometer, and a maximum pressure of $19 \mathrm{kbar}$. The grey area in figure 8 is for the 10 to 8 kbar gap of the other scenario where epidote crystalized after plagioclase.

\section{CONCLUSIONS}

Magmatic epidote might be identified in granitoids based on textural relations that indicate igneous processes. For MFB, the main textures that suggest a primary relation are epidote zonation, with allanitic cores, and resorbed boundaries when in contact with a quartz-feldspathic matrix. This latter relationship not only implies a primary origin for epidote, but also that the host rock crystallized outside epidote stability field. Unfortunately, chemical criteria cannot be used to identify the primary origin of epidote. Although most magmatic epidote have Ps\% content between $20-30 \%$, metamorphic epidote might have also exactly the same Ps\% content. However, if epidote has around $20-30 \%$
Ps\% in granitoid rocks, it is worth checking textural relations in order to identify a magmatic origin.

The presence of primary epidote is also a proxy for pressure. It is possible to use the rock crystallization order to constrain rock crystallization conditions, once the first appearance of epidote is indicative of certain pressure ranges. In this case, epidote indicates a minimum pressure of about $8 \mathrm{kbar}$, but maximum pressure cannot be obtained with total confidence.

For the MFB, epidote is metastable for granodioritic compositions and stable in tonalitic compositions. These evidences made possible to contrain the P-T history of the rocks in this batholith. The MFB probably began to crystallize in a pressure range between 8-19 kbar and followed its final crystallization stage between $700^{\circ} \mathrm{C}$ to $775^{\circ} \mathrm{C}$. Other barometry methods can be used to further constrain these conditions.

\section{REFERENCES}

Ave Lallement H.G., Carter N.L. (1971). Pressure dependence of quartz defformation lamellae orientation. American Journal of Science, 270, 218-235.

Brandon, A. D., Creaser, R. A., Chacko, T. (1996). Constraints on rates of granitic magma transport from epidote dissolution kinetics. Science, 271, 1845-1848.

Belen Perez, M., Baldo, E.G., Saieg, A., Dominguez, J. (1996). Tipologia de epidotos de granitoides de la Sierra Chica Septentrional de Cordoba, Argentina. Revista Instituto de Geologia y Mineria, 11(1), 71-91.

Campos-Neto, M.C., Figueiredo, M.C.H. (1995). The Rio Doce orogeny, southeastern Brazil. Journal South American Earth Science, 8, 143-162.

Cornelius, H.P. (1915). Geologische Beobachtungen im Gebiet des Forno-Gletschers (Engadin). Centralblatt für Mineral Geol Paläontol 1913, 8, 246-252.

Costa, A. G., Rosière, C. A., Moreira, L. M., Fischel, D. P. (1995). Caracterizacão geotectônica do setor setentrional do Cinturão Ribeira: Evidência de acrescão neoproterozóica no leste de Minas Gerais. Geonomos 3, 51-68

De Campos, C., Mendes, J. C., Ludka, I. P., Medeiros, S. R. de, Costa-de-Moura, J., Wallfass, C. M. (2004). A review of 
the brasiliano magmatism in Southern Espírito Santo, Brazil, with enphasis on post-collisional magmatism. Journal of the Virtual Explorer, 17, https://virtualexplorer.com.au/article/2004/106/brasilianomagmatism/index.html.

Dawes, R.L., Evans, B.W. (1991). Mineralogy and geothermobarometry of magmatic epidote-bearing dikes, Front Range, Colorado. Geolocial Society of America Bulletin, 103, 1017-1031.

Evans, B.W., Vance, J.A. (1987). Epidote phenocrysts in dacitic dikes, Boulder County, Colorado. Contributions to Mineralogy and Petrology, 96, 178-185.

Ferreira, V.P., Sial, A.N., Pimentel, M.M., Armstrong, R., Spicuzza, M.J., (2011). Contrasting sources and P-T crystallization conditions of epidote-bearing granitic rocks, northeastern Brazil: O, Sr, and Nd isotopes. Lithos, 121, 189201.

Galindo, A. C., (1993). Petrologia dos granitoides Brasilianos da região de Caraúbas e Umarizal (Oeste do Rio Grande do Norte). Tese de doutoramento, Belém: Universidade Federal do Pará - UFPA.

Hirth G., Tullis J. (1992). Dislocation creep regimes in quarzt aggregates. Journal of Structural Geology, 14,145-149.

Johnston, A. D., Wyllie, P. J. (1988). Constraints on the origin of Archean trondhjemites based on phase relationship of Nuk gneiss with $\mathrm{H}_{2} \mathrm{O}$ at 15 kbar. Contribution to Mineralogy and Petrology, 100, 35-46.

Kruhl J.H. (1996). Prism- and basal-plane paralles subgrain boundaries in quartz: a microstructural geothermobarometrer. Journal of Metamorphic Geology, 14,581-589.

Mascarenhas, I. E. (2015). Petrologia do Batólito Muniz Freire, Espirito Santo. Trabalho de Formatura, São Paulo: Universidade de São Paulo - USP.

Naney, M.T. (1983). Phase equilibria of rock-forming ferromagnesian silicates in granitic systems. American Journal of Sciences, 283, 993-1033.

Narduzzi, F., Farina, F., Stevens, G., Lana, C., Nalini Jr., H. A. (2017). Magmatic garnet in the Cordilleran-type Galiléia granitoids of the Araçuaí belt (Brazil): Evidence for crystallization in the lower crust. Lithos, 282-283, 82-97.

Passchier, C. W., Trouw, R. A. J. (2005) Microtectonics. New York: Springer-Verlag.
Pedrosa-Soares, A. C., Wiedemann-Leonardos, C. M., (2000). Evolution of the Araçuaí Belt and its connection to the Ribeira Belt, Eastern Brazil. In: U. Cordani, E. Milani, A. Thomaz-Filho A., D. A. Campos (Eds.), Tectonic Evolution of South America (265-285). São Paulo: Sociedade Brasileira de Geologia.

Pedrosa-Soares, A. C., Wiedemann, C. M., Fernandes, M. L. S., Faria, L.F., Ferreira, J.C.H. (1999). Geo-tectonic significance of the Neoproterozoic granitic magmatism in the Araçuaí belt, Eastern Brazil: a model and pertinent questions. Revista Brasileira de Geocienciências, 29, 57-64.

Pedrosa-Soares, A. C., Noce, C. M., Wiedemann, C. M., Pinto, C. P. (2001). The Araçuaí-West Congo orogen in Brazil: An overview of a confined orogen formed during Gondwanland assembly. Precambrian Research, 110, n. 1-4, p.307-323.

Pedrosa-Soares A.C., Alkmin F.F.; Tack L., Noce C.M., Babinski M.; Silva L.C.; Martins Neto M. (2008). Similarities and differences between the Brazilian and African counterparts of the Neoproterozoic Araçuaí West Congo orogen. Geological Society Special Publication, 294, 153-172.

Pedrosa-Soares, A.C., De Campos, C.P., Noce, C.M.; Silva, L.C.; Novo, T., Roncato, J., Medeiros, S., Castañeda, C., Queiroga, G., Dantas, E., Dussin, I., Alkmin, F. 2011. Late Neoproterozoic-Cambrian granitic magmatism in the Araçuaí orogeny (Brazil), the Eastern Brazilian Province and related mineral resources. Geological Society of London, Special Publication, 550, 25-51.

Rogers, J. J. W., Santosh, M. (2004). Continents and supercontinents. Oxford University Press.

Silva, M. A., Camozzato, E., Paes, V.J.C., Junqueira, P. A., Ramgrab, G. E. (2004). Folha SF.24-Vitoria. In: C. Schobbenhaus, J. H. Gonçalves, J. O. S Santos, M. B. Abram, R. Leão Neto, G. M. M. Matos, R. M. Vidotti, M. A. B. Ramos, J. D. A. de Jesus, (Eds.), Carta Geológica do Brasil ao Milionésimo, Sistema de Informações Geográficas. Programa Geologia do Brasil. CPRM, Brasília. CD-ROM.

Schmidt, M. W., Poli, S. (2004) Magmatic Epidote. Reviews in Mineralogy and Geochemestry, 56, 399-430.

Schmidt, M. W., Thompson, A. B. (1996) Epidote in calcalkaline magmas: An experimental study of stability, phase relationships, and the role of epidote in magmatic evolution. American Mineralogist, 81,462-474. 
Sial, A. N. (1990). Epidote-bearing calc-alkalic granitoids in northeast Brazil. Revista Brasileira de Geociencias, 20, 88100.

Sial, A. N. (1993). Contrasting metaluminous magmatic epidote-bearing granitic suites from two Precambrian Foldbelts in Northeast Brazil. Anais da Academia Brasileira de Ciencias, 65, 141-162.

Sial, A. N., Toselli, A. J., Saavedra, J., Parada, M. A., Ferreira, V. P. (1999). Emplacement, petrological and magnetic susceptibility characteristics of diverse magmatic epidotebearing granitoid rocks in Brazil, Argentina and Chile. Lithos, 46, 367-392.

Sial, A. N., Vasconcelos, P. M., Ferreira, V. P., Pessoa, R. R., Brasilino, R. G., Morais Neto, J. M. (2008). Geochronological and mineralogical constraints on depth of emplacement and ascencion rates of epidote-bearing magmas from northeastern Brazil. (2008). Lithos, 105, 225-238.

Siga Jr, O. (1986). A evolução geotectônica da porção nordeste de Minas Gerais, com base em interpretações geocronológicas. Dissertação (Mestrado). São Paulo: Instituto de Geociências - USP.

Signorelli, N. (1993) Mapa geológico da Folha Afonso Cláudio - SF24-V-A-II. Programa de Levantamentos Geológicos Básicos do Brasil, DNPM/CPRM. Escala 1:100000. Brasília: Companhia de Pesquisa de Recursos Minerais/CPRM.

Stipp, M., Stünitz, H., Heilbronner, R., Schmid, S. M. (2002). Dynamic recrystallization of quartz: Correlation between natural and experimental conditions. London Special Publications, 200, 171-190.

Trommsdorf, V., Connoly, J. A. D. (1996) The ultramafic contact aureole about the Bregaglia (Bergell) tonalite: Isograds and a thermal model. Schweizer Mineralogische und Petrographische Mitteilungen, 76, 537-547.

Trompette, R. (1994) Geology of Western Gondwana (2000500 Ma). Pan-African-Brasiliano aggregation of South America and Africa. Rotterdam: A.A. Balkema.

Tulloch, A. J. (1979). Secondary Ca-Al, Silicates as low grade alteration products of granitoid biotite. Contributions to Mineralogy and Petrology, 69, 105-117.

Zen, E-an, Hammarstrom, J. M. (1984). Magmatic epidote and its petrologic significance. Geology, 12,515-518 